UNIVERSIDADE DE SÃO PAULO

FACULDADE DE ECONOMIA, ADMINISTRAÇÃO E CONTABILIDADE DE RIBEIRÃO PRETO

DEPARTAMENTO DE ADMINISTRAÇÃO

MESTRADO EM ADMINISTRAÇÃO DE ORGANIZAÇÕES

NAYELE MACINI

Sustentabilidade e Gestão de Pessoas: evidências do setor bancário brasileiro.

Orientadora: Profa. Dra. Adriana Cristina Ferreira Caldana 
Prof. Dr. Marco Antonio Zago

Reitor da Universidade de São Paulo

Prof. Dr. Dante Pinheiro Martinelli

Diretor da Faculdade de Economia, Administração e Contabilidade de Ribeirão Preto

Prof $^{\mathrm{a}}$. Dra ${ }^{\mathrm{a}}$. Sonia Valle Walter Borges de Oliveira

Chefe de Departamento de Administração / FEA-RP 


\section{NAYELE MACINI}

Sustentabilidade e Gestão de Pessoas: evidências do setor bancário brasileiro.

Dissertação apresentada ao Programa de PósGraduação em Administração de Organizações da Faculdade de Economia, Administração e Contabilidade de Ribeirão Preto da Universidade de São Paulo, para obtenção do título de Mestre em Ciências. Versão Corrigida. A original encontra-se disponível na FEA-RP/USP.

Orientadora: Profa. Dra. Adriana Cristina Ferreira Caldana 
Autorizo a reprodução e divulgação total ou parcial deste trabalho, por qualquer meio convencional ou eletrônico, para fins de estudo e pesquisa, desde que citada a fonte.

FICHA CATALOGRÁFICA

MACINI, Nayele.

Sustentabilidade e Gestão de Pessoas: evidências do setor bancário brasileiro. Ribeirão Preto, 2015.

173 p. : il. ; $30 \mathrm{~cm}$

Dissertação (Mestrado) apresentada à Faculdade de Economia, Administração e Contabilidade de Ribeirão Preto/USP Universidade de São Paulo, 2015. Área de concentração: Gestão da Inovação e Sustentabilidade.

Orientadora: CALDANA, Adriana Cristina Ferreira.

1. Sustentabilidade Organizacional. 2. Setor Bancário Brasileiro. 3. Gestão Sustentável de Pessoas. 


\section{FOLHA DE APROVAÇ̃̃O}

Nome: MACINI, Nayele

Título: Sustentabilidade e Gestão de Pessoas: evidências do setor bancário brasileiro.

Dissertação apresentada ao Programa de PósGraduação em Administração de Organizações da Faculdade de Economia, Administração e Contabilidade de Ribeirão Preto da Universidade de São Paulo, como requisito parcial para obtenção do título de Mestre em Ciências.

Área de Concentração: Gestão da Inovação e Sustentabilidade.

Aprovado em:

Banca examinadora

Prof. Dr.

Instituição:

Assinatura:

Prof. Dr.

Instituição:

Assinatura:

Prof. Dr.

Instituição:

Assinatura: 


\section{AGRADECIMENTOS}

Em primeiro lugar agradeço a Deus, que em todos os momentos que eu não acreditava mais em mim, Ele continuou acreditando, me iluminando e me inspirando durante toda essa jornada, e proporcionando que eu cruzasse com pessoas tão especiais em meu caminho.

Aos meus pais, pelo dom da vida, por toda educação, apoio financeiro e emocional proporcionado, partilho a alegria desse momento. À minha irmã Giovanna que sempre esteve disposta a ser minha confidente, e que despertou em mim o entendimento de que o futuro é feito a partir da constante dedicação presente. Agradeço por todo amor, paciência e compreensão de vocês.

Aos meus familiares que torceram por mim, me incentivaram, apoiaram. Uma gratidão especial a tia Marina, pela companhia e paciência em me auxiliar na execução das entrevistas, e para tia Bete que permitiu que isso acontecesse.

À minha orientadora Prof. Dra. Adriana Caldana, por ter me aceitado, apoiado, por toda sua simpatia e alto astral que modificavam meus dias de tensão, por todo ensinamento, experiência repassada e proporcionada, uma pessoa que quero levar para a vida.

Ao meu estimado amigo Fernando Putti, pelo incentivo ao mestrado, sendo sempre paciente e solícito em tudo que precisei. Palavras não são suficientes para demonstrar o quanto sou grata.

À minha estimada Camila Cintra, que a vida permitiu que mesmo com a distância, nada se modificasse, e por toda sua paciência e dedicação em me esclarecer as dúvidas, por me ajudar a coletar os dados, pela sua amizade.

Ao amigo Marlon, por toda sua dedicação, companheirismo, por me ajudar a me desenvolver, evoluir, me guiar, por toda sua disponibilidade em ajudar sempre, desde quando cruzamos na primeira prova de aluno especial. Você é um presente em minha vida.

Às minhas amigas Camila Ruiz, Letícia Bignardi e Mayara Semeghini por todo suporte, carinho, acolhimento de quando aqui cheguei. Sou eternamente grata a vocês por essa amizade. À minha amiga Claudia Aquino, por toda paciência, atenção, toda a amizade durante esses anos, me aconselhando, consolando, incentivando.

Aos meus amigos da Unesp de Tupã por toda torcida antes do meu ingresso ao mestrado, por todo conhecimento passado, momentos de felicidade, que se estenderam mesmo após nosso período de graduação.

À minha querida Ana Claudia Bansi, presente desses anos de mestrado. Agradeço pela paciência, por escutar meus dramas, por me encorajar a seguir em frente, por ser minha companheira nos momentos de descontração, por todo ensinamento, risadas, pela amizade. 
À amiga Maria Gabriela, que sempre esteve disposta a me ouvir, a me encorajar, compartilhando as experiências, angústias, conhecimentos. Sou eternamente grata por tudo.

À querida Elisa, obrigada por compartilhar sua fé tão bonita e contagiante, toda sua alegria em nossos encontros, sentirei saudades.

Ao amigo Bruno, por ser meu confidente, me ajudar a enxergar as coisas por outro ângulo, por toda parceria durante esses anos, a alegria em nossos encontros, um irmão que ganhei no mestrado.

À querida Patrícia, que desde nosso processo seletivo sempre me proporcionou uma alegria, paz e amizade indescritíveis. Obrigada por todos os conselhos, pela torcida da minha felicidade, por todo conhecimento e preocupação comigo.

Ao estimado Dyego, que com tão pouca idade tem tanta sabedoria, tanta serenidade, tanta disposição em ajudar, em explicar as teorias. Palavras não são suficientes para mostrar minha gratidão em tê-lo como amigo.

À minha querida amiga Janaína, que esteve presente desde meu primeiro dia de aula no mestrado, por todo seu apoio, seu carinho em me ouvir, em me fortalecer para o processo seletivo, para a vida, por todos os momentos compartilhados, sou muito grata.

À minha amiga Larissa, que com todo seu conhecimento me ajudou a evoluir e me desenvolver muito. Obrigada por todos os momentos de confidência, descontração, companheirismo.

A todos colegas do PPGAO-USP que colaboraram com meu desenvolvimento pessoal, intelectual, compartilhando suas experiências e conhecimentos.

Ao corpo docente e aos funcionários do PPGAO-USP por todas as contribuições ao meu desenvolvimento acadêmico e intelectual. Em especial Solange Garcia, Luciana Morillas, Lara Liboni e Luciano Munck por todas as contribuições à realização deste trabalho.

A Universidade de São Paulo (USP) e a Coordenação de Aperfeiçoamento de Pessoal de Nível Superior (CAPES) por me proporcionarem condições básicas para cursar o mestrado. 
"Quem se arrisca a andar por ares nunca antes respirados ou pensar fora da curva tem grandes chances de encontrar pedras no caminho. No entanto, ninguém é digno de contribuir para a ciência se não usar suas dores e insônias nesse processo. Não há céu sem tempestade. Risos e lágrimas, sucessos e fracassos, aplausos e vaias fazem parte do currículo de cada ser humano, em especial daqueles que são apaixonados por produzir novas ideias. " 


\section{RESUMO}

MACINI, N. Sustentabilidade e Gestão de Pessoas: evidências do setor bancário brasileiro. 2015. 173f. Dissertação (Mestrado) - Faculdade de Economia, Administração e Contabilidade de Ribeirão Preto, Universidade de São Paulo, Ribeirão Preto, 2015.

Todas as áreas de uma organização dependem em grande medida da ação das pessoas. Logo, se o intuito é ser sustentável, a organização deve proporcionar o alinhamento entre as diretrizes da sustentabilidade e suas iniciativas. Um dos desafios da gestão de pessoas está em gerir as organizações em relação aos seus recursos humanos-sociais, naturais e econômicos, envolvendo a sustentabilidade organizacional à sua área de atuação. $\mathrm{O}$ setor bancário brasileiro por apresentar um grande poder econômico e financeiro, tem capacidade de investir em ações abrangendo os âmbitos social e ambiental. Equilibrar os investimentos para os três aspectos do tripé da sustentabilidade é parte das transformações sugeridas pela GSP (Gestão Sustentável de Pessoas). A fim de identificar se a gestão de pessoas do setor bancário brasileiro está alinhada às estratégias de sustentabilidade organizacional, analisando suas iniciativas da GSP, foi desenvolvida uma análise descritiva, qualitativa-quantitativa, baseada em análise de conteúdo e análises das informações da triangulação de dados envolvendo: os relatórios anuais ou de sustentabilidade dos bancos, acórdãos trabalhistas finalizados no ano de 2014 do Tribunal Regional do Trabalho da 2a Região de São Paulo, e informações da Federação Brasileira de Bancos e do Sindicato dos Bancários e Financiários de São Paulo, Osasco e Região. Dentre os subsistemas de Gestão de pessoas analisados, a área de Recrutamento e Seleção, Sistema de Pagamento e Recompensa e Gestão de Desempenho e Avaliação, são os que precisam de maior detalhamento no reporte dos bancos. Dos acórdãos analisados, os índices mais recorrentes foram queixas relativas às horas extras, e em seguida, indenizações por assédio moral. As solicitações de doenças profissionais tiveram índices baixos, apresentando melhoria no setor frente à essas questões. Os bancos em geral não atingiram o nível de integrar e embutir extremamente as diretrizes em cada um dos aspectos do tripé da sustentabilidade, sendo o Itaú Unibanco o banco que apresentou mais detalhadamente suas ações. Embora o interesse na GSP, que agrega a sustentabilidade organizacional aos subsistemas de gestão de pessoas, tem sido recorrente, mais pesquisas são necessárias para dar forma e desenvolver um guia de implicações práticas, com clareza e objetividade para serem seguidas pelas organizações. Por meio da metodologia sistêmica (SSM), um quadro de ações foi desenvolvido, com intuito de proporcionar apoio, tanto estratégico quanto operacional, ao setor bancário brasileiro, para que a sustentabilidade organizacional seja implantada em suas ações. Nesse sentido, esta pesquisa agregou valor por avançar na exploração desta lacuna na literatura, bem como no delineamento das categorias dos subsistemas de Gestão de Pessoas. Por fim, a pesquisa proporcionou reflexões teóricas quanto a GSP e, a análise das ações e iniciativas do setor bancário brasileiro permitiu identificar o atual panorama do setor no que tange à sustentabilidade organizacional.

Palavras-chave: Sustentabilidade Organizacional. Setor bancário brasileiro. Gestão sustentável de pessoas. 


\begin{abstract}
MACINI, N. Sustainability and people management: evidences of the Brazilian banking industry. 2015. 173f. Dissertation (Master) - School of Economics, Administration and Accounting of Ribeirão Preto, University of São Paulo, Ribeirão Preto, 2015.
\end{abstract}

All areas of organization depends largely on the action of the people. Therefore, if the organization's purpose is to be sustainable, it must provide the alignment between the guidelines of sustainability and its initiatives. One of the challenges of people management is to manage organizations in relation to their human and social, natural and economic resources, involving organizational sustainability to their area of expertise. The Brazilian banking industry presents a great economic and financial power, so it has the capacity to invest in actions covering the social and environmental spheres. Balance investments for the three aspects of sustainability tripod is part of the changes suggested by the Sustainable HRM (Human Resources Management). In order to identify if the people management of the Brazilian banking sector is aligned with organizational sustainability strategies, analyzing their Sustainable HSM initiatives, it was developed a descriptive analysis, qualitative and quantitative, based on content analysis and analysis of the data triangulation information involving: the annual reports or sustainability of banks, labor judgments finalized in 2014 of the Regional Labor Court of the 2nd Region of São Paulo, and information of the Brazilian Federation of Banks and the Union of Banking and Financiários of São Paulo, Osasco and Region. Among the Management subsystems analyzed people, the area of Recruitment and Selection, System Pay and Reward and Performance Management and Evaluation, are in need of more detailed reporting of the banks. Among the judgments analyzed, the most recurrent rates were complaints relating to overtime, and then compensation for bullying. Requests for occupational diseases had low rates, with improvements in the sector ahead to these issues. Banks in general have not reached the level to integrate and extremely embed the guidelines in each of the aspects of the triple bottom line, with Itaú Unibanco the bank presented in more detail their actions. Although interest in Sustainable HSM, which aggregates organizational sustainability to people management subsystems, have been recurrent, more research was needed to shape and develop a guide of practical implications, clearly and objectively to be followed by organizations. Through the soft systemic methodology (SSM), an action framework was developed, aiming to provide both strategic and operational support to the Brazilian banking sector, so that organizational sustainability is deployed in their actions. In this sense, this research has added value for advancing the exploration of this gap in the literature as well as in the design category of the subsystems of Personnel Management. Finally, the research provided theoretical reflections as the Sustainable HSM and the analysis of the actions and initiatives of the Brazilian banking industry has identified the current situation of the sector with regard to organizational sustainability.

Keywords: Organizational sustainability. Brazilian banking industry. Sustainable Human Resources Management. 


\section{LISTA DE QUADROS}

Quadro 1 - Principais características dos diferentes níveis de estágio da gestão verde ..........26

Quadro 2. Quadro síntese dos modelos emergentes de Gestão de Pessoas .............................29

Quadro 3 - Subsistemas de Gestão de Pessoas - Recrutamento e Seleção ................................ 32

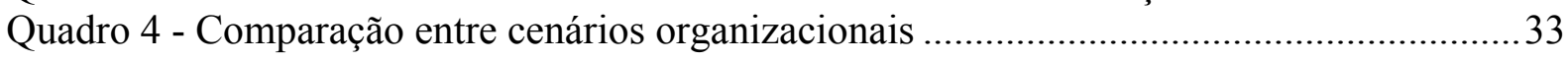

Quadro 5 - Subsistema de Gestão de Pessoas - Treinamento e Desenvolvimento .....................35

Quadro 6 - Ações para que o sistema de T\&D torne-se estratégico ........................................36

Quadro 7- Subsistema de Gestão de Pessoas - Pagamento e Recompensa ...............................38

Quadro 8 - Subsistema de Gestão de Pessoas - Desempenho e Avaliação ...............................39

Quadro 9 - Modelo de Walton de Qualidade de Vida no Trabalho ...........................................41

Quadro 10 - Subsistema de Gestão de Pessoas - Saúde, Segurança, Qualidade de Vida no

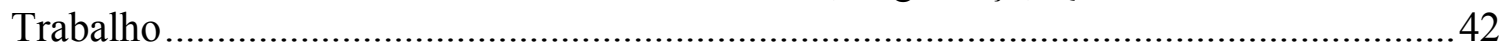

Quadro 11 - Tipos de relatórios de sustentabilidade .......................................................... 44

Quadro 12 - Os 10 Princípios do Pacto Global das Nações Unidas ........................................46

Quadro 13 - Agenda de políticas gerais para a promoção do trabalho decente pela OIT ........48

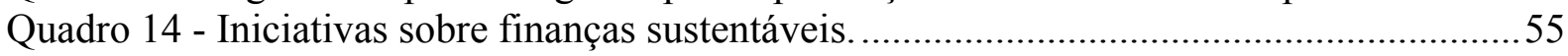

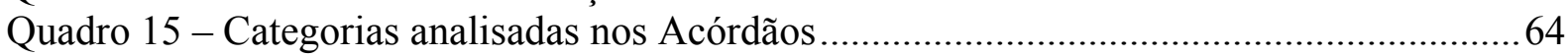

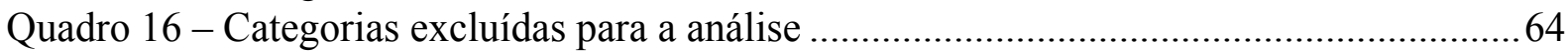

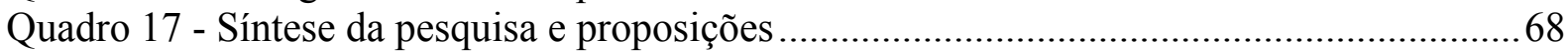

Quadro 18 - Síntese das Práticas de Recrutamento e Seleção ................................................85

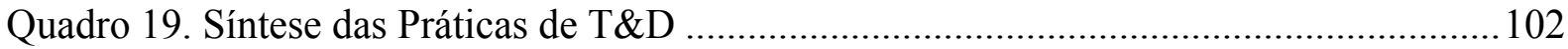

Quadro 20 - Tipos de Remuneração Variável Itaú-Unibanco ............................................... 109

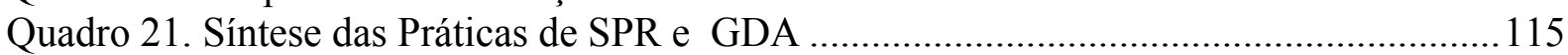

Quadro 22 - Atividades que contribuem para a Segurança do Trabalho no Banco Itaú-

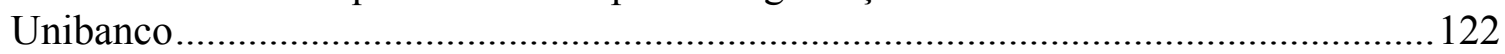

Quadro 23. Síntese das Práticas de SSQVT .................................................................... 130

Quadro 24. Metas e desafios para os próximos anos nos bancos ......................................... 143

Quadro 25. Definições essenciais da SSM para Gestão Sustentável de Pessoas no Setor

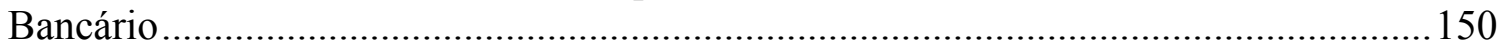

Quadro 26. Ações da Gestão Sustentável de Pessoas por Subsistema .................................. 151

Quadro 27. Resultado da verificação das proposições da pesquisa........................................ 157 


\section{LISTA DE TABELAS}

Tabela 1 - Classificação dos 5 maiores bancos brasileiros....................................................51

Tabela 2. Conhecimento das Vagas de Emprego do Setor Bancário Brasileiro........................53

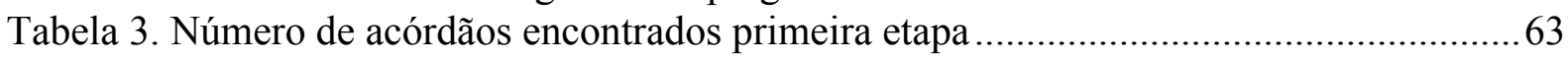

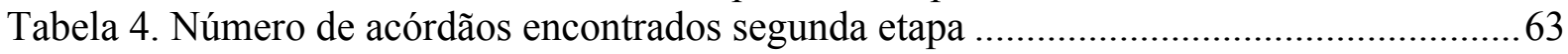

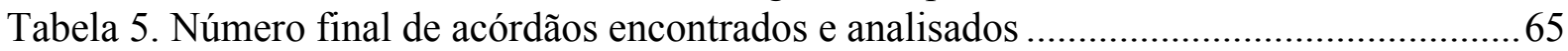

Tabela 6. Número de funcionários versus número de acórdãos encontrados.........................65

Tabela 7 - Rotatividade por Faixa Etária do Banco do Brasil ................................................ 72

Tabela 8 - Rotatividade por região geográfica do Banco do Brasil........................................73

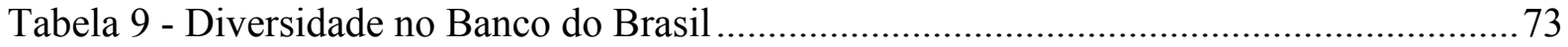

Tabela 10 - Taxa de contratação por faixa etária, gênero e região do Banco Itaú-Unibanco...74

Tabela 11 - Rotatividade por faixa etária, gênero e região do Banco Itaú-Unibanco ...............75

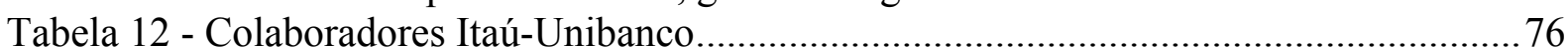

Tabela 13 - Quadro de Pessoal da CEF referente à diversidade. ............................................ 78

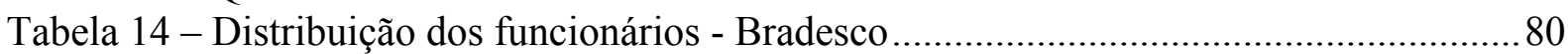

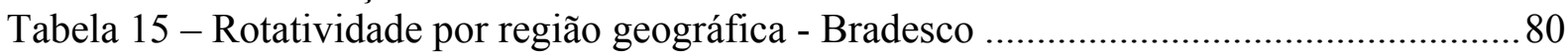

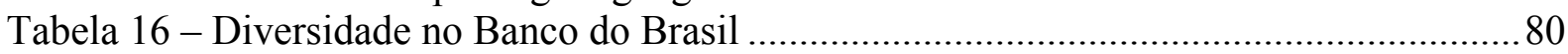

Tabela 17 - Número de funcionários do Santander discriminados por gênero.........................82

Tabela 18 - Número de funcionários do Santander discriminados por Região Geográfica..... 82

Tabela 19 - Número de funcionários do Santander discriminados por faixa etária.................82

Tabela 20 - Número de Funcionários do Santander discriminados por faixa etária ................83

Tabela 21 - Média de horas de treinamento por gênero e categoria funcional do Banco do

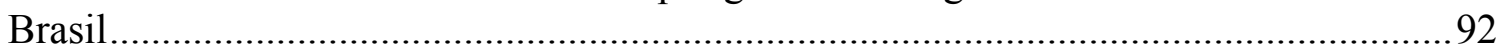

Tabela 22 - Média de Horas em Treinamento por Categoria Funcional e Gênero do Banco

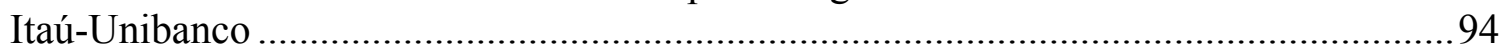

Tabela 23 - Média de horas de Treinamento por gênero e categoria funcional na CEF.........96

Tabela 24 - Média de horas anual de treinamento ................................................................ 98

Tabela 25 - Número de funcionários do Santander treinados em 2013 por temas ................ 100

Tabela 26 -Número médio de treinamento por gênero e categoria funcional no Santander.. 101

Tabela 27 - Remuneração por gênero e categoria funcional do Banco do Brasil .................. 106

Tabela 28 - Proporção da remuneração entre homens e mulheres - Bradesco ....................... 112

Tabela 29 - Porcentagem de funcionários por categoria funcional que recebem avaliação de

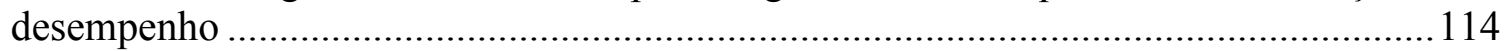

Tabela 30. Igualdade de remuneração nos acórdãos trabalhistas ........................................ 117

Tabela 31 - Taxas de Saúde e Segurança no Trabalho no Banco do Brasil ........................... 120

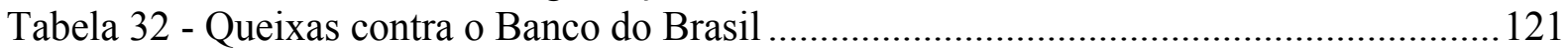

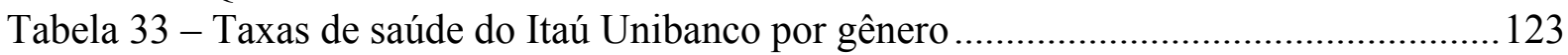

Tabela 34 - Taxas de saúde do Itaú Unibanco por região geográfica..................................... 123

Tabela 35 - Queixas contra o Itaú Unibanco ..................................................................... 125

Tabela 36 - Índice de licenças por Acidente de Trabalho da Caixa por gênero ..................... 126

Tabela 37 - Queixas contra a Caixa Econômica Federal ..................................................... 127

Tabela 38 - Indicadores de Segurança e Saúde Ocupacional Bradesco................................ 127

Tabela 39 - Queixas contra o Banco Bradesco ....................................................................... 128

Tabela 40 -Queixas e reclamações relacionadas aos direitos humanos no Santander ........... 129

Tabela 41. Queixas contra o Santander ............................................................................... 130

Tabela 42. Comparativo de queixas trabalhistas por banco .............................................. 133

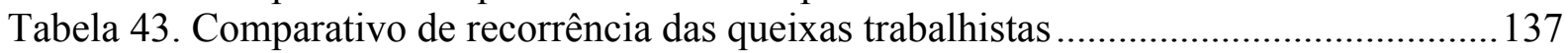




\section{LISTA DE FIGURAS}

Figura 1. Evolução de algumas iniciativas acerca da sustentabilidade ...................................22

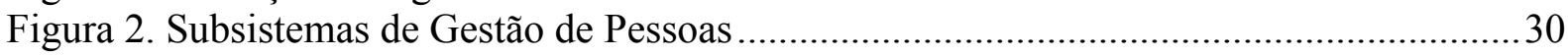

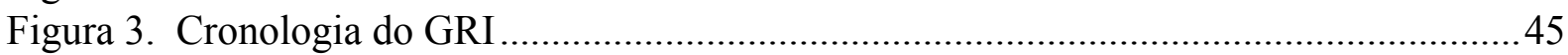

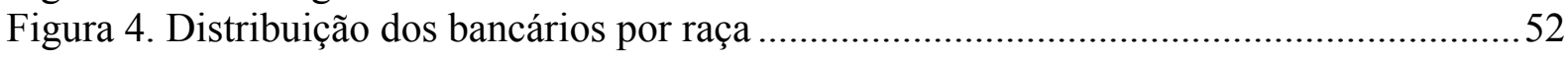

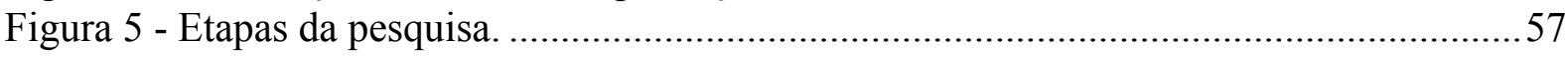

Figura 6. Importância do papel da Gestão de Pessoas no aspecto social interno .................... 147

Figura 7. Situação problemática estruturada ..................................................................... 149

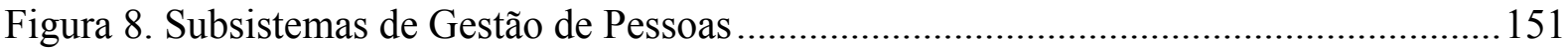

Figura 9. Gestão Sustentável de Pessoas no Setor Bancário Brasileiro ................................. 153

Figura 10. Modelo Conceitual de Gestão Sustentável de Pessoas no Setor Bancário Brasileiro 


\section{LISTA DE ABREVIATURAS E SIGLAS}

$\begin{array}{ll}\text { BB } & \text { Banco do Brasil } \\ \text { CEF } & \text { Caixa Econômica Federal } \\ \text { CHA } & \text { Conhecimentos, Habilidades e Atitudes } \\ \text { CLT } & \text { Consolidação das Leis do Trabalho } \\ \text { CTPS } & \text { Carteira de Trabalho e Previdência Social } \\ \text { DORT } & \text { Doenças Osteoarticulares Relacionadas ao Trabalho } \\ \text { FEBRABAN } & \text { Federação Brasileira de Bancos } \\ \text { FGTS } & \text { Fundo de Garantia por Tempo de Serviço } \\ \text { GC } & \text { Global Compact } \\ \text { GDA } & \text { Gestão de Desempenho e Avaliação } \\ \text { GEE } & \text { Gases do Efeito Estufa } \\ \text { Green HRM } & \text { Green Human Resources Management } \\ \text { GRI } & \text { Global Reporting Initiative } \\ \text { HRM } & \text { Human Resources Management } \\ \text { INSS } & \text { Instituto Nacional do Seguro Social } \\ \text { LER } & \text { Lesão por Esforço Repetitivo } \\ \text { OIT } & \text { Organização Internacional do Trabalho } \\ \text { ONU } & \text { Organização das Nações Unidas } \\ \text { PDV } & \text { Plano de Demissão Voluntária } \\ \text { PLR } & \text { Participação nos Lucros e Resultados } \\ \text { R\&S } & \text { Recrutamento e Seleção } \\ \text { SHRM } & \text { Strategic Human Resources Management } \\ \text { SPR } & \text { Sistema de Pagamentos e Recompensas } \\ \text { SSM } & \text { Softy System Methodology } \\ \text { SSQVT } & \text { Saúde, Segurança e Qualidade de Vida no Trabalho } \\ \text { T\&D } & \text { Treinamento e Desenvolvimento } \\ \text { TBL } & \text { Triple Bottom Line }\end{array}$




\section{SUMÁRIO}

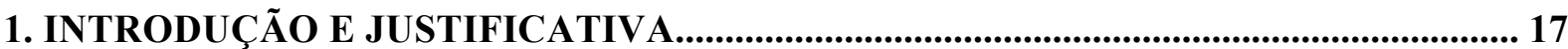

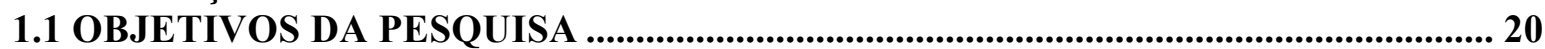

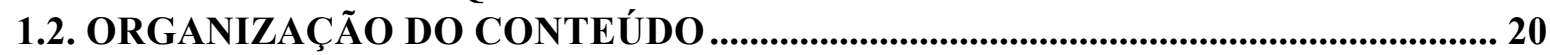

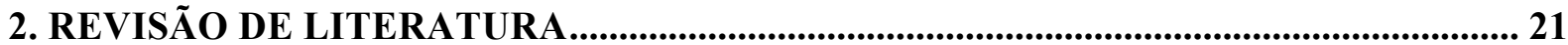

2.1 CARACTERIZAÇÕES CONCEITUAIS DE SUSTENTABILIDADE.......................... 21

2.2 SUSTENTABILIDADE ORGANIZACIONAL E GESTÃO DE PESSOAS ................ 23

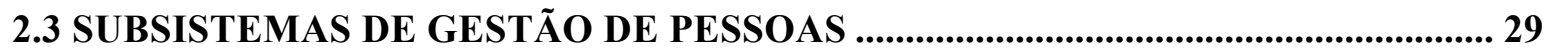

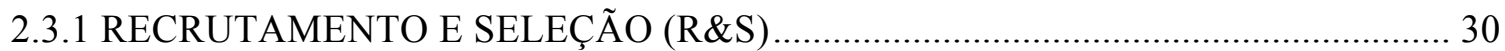

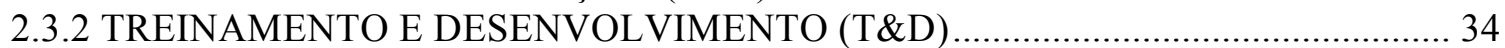

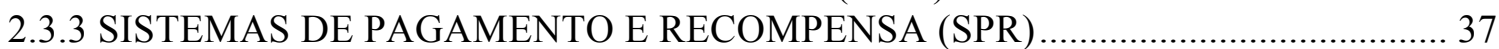

2.3.4 GESTÃO DE DESEMPENHO E AVALIAÇÃO (GDA) …........................................ 38

2.3.5 SAÚDE, SEGURANÇA E QUALIDADE DE VIDA NO TRABALHO (SSQVT) .... 40

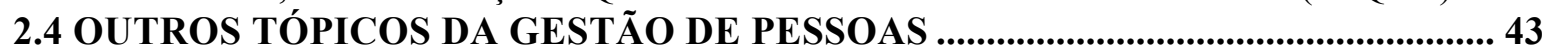

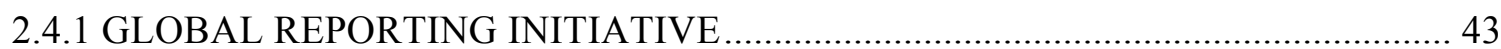

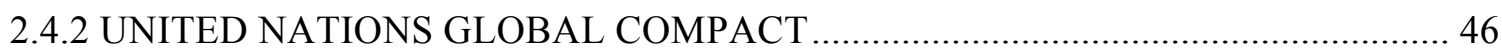

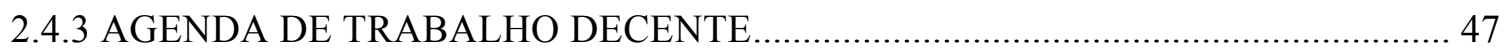

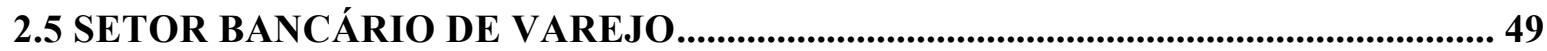

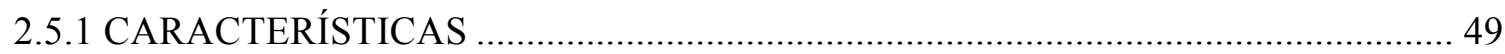

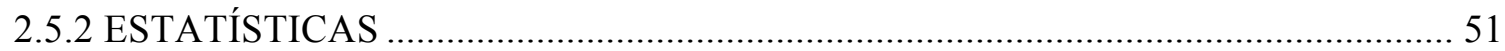

2.5.3 GESTÃO DE PESSOAS NO SETOR BANCÁRIO ................................................... 53

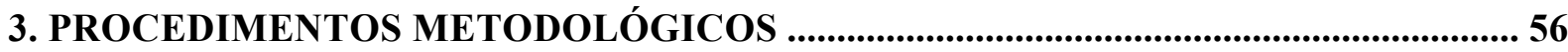

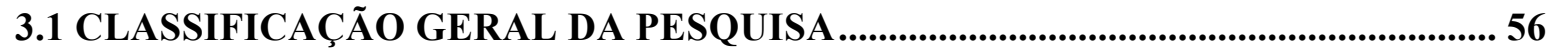

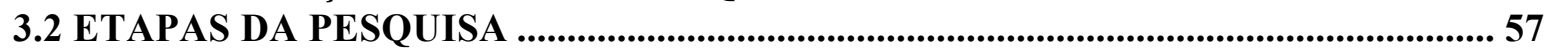

3.3 OBJETIVOS DA PESQUISA E REVISÃO DE LITERATURA ................................. 57

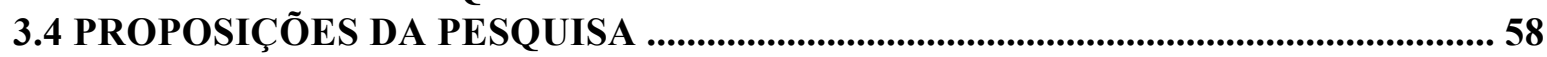

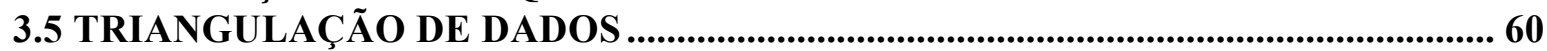

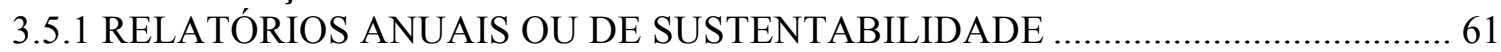

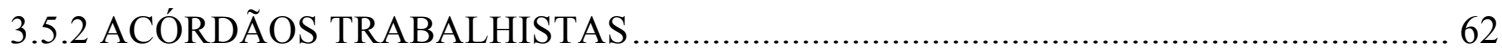

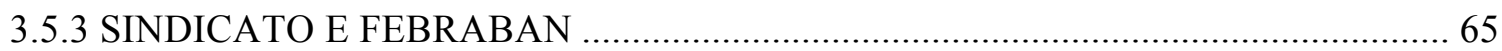

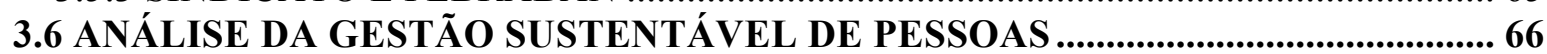

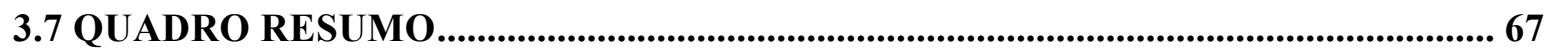

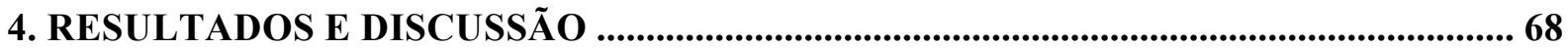

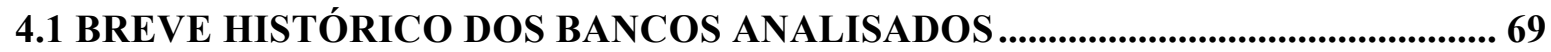

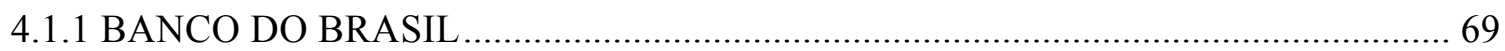

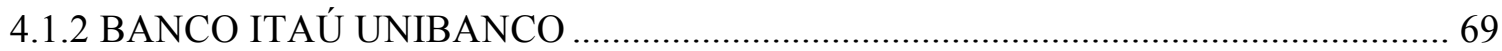

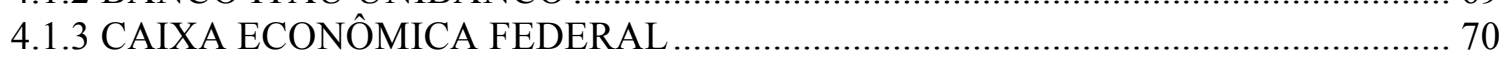

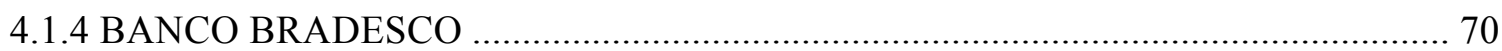

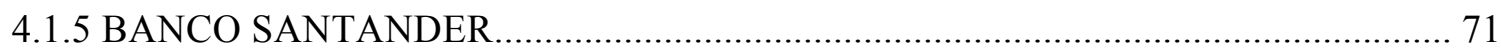

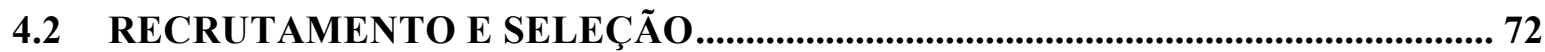

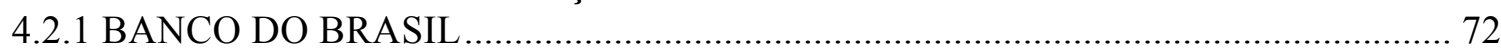

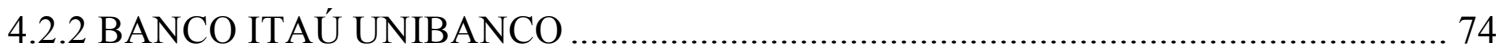

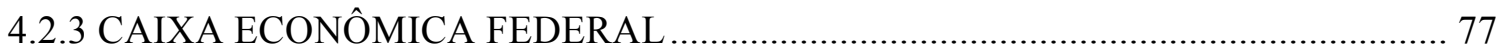

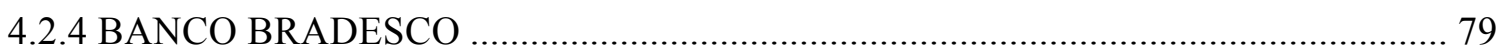

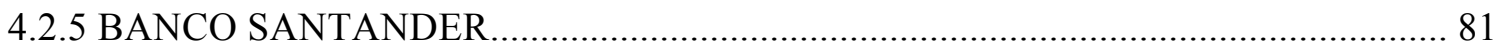

4.2.6. SÍNTESE DAS PRÁTICAS DE RECRUTAMENTO E SELEÇÃO............................ 85

4.3 TREINAMENTO E DESENVOLVIMENTO .....................................................91

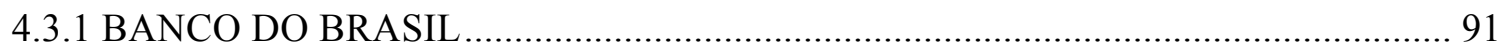

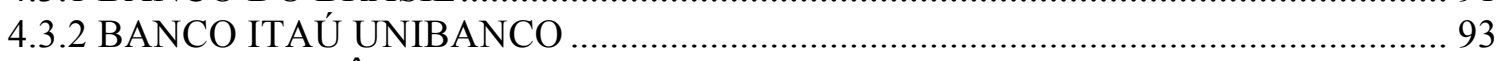

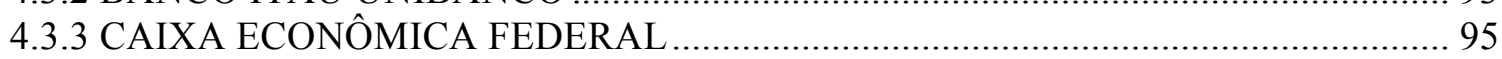

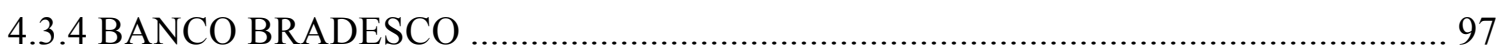


4.3.5 BANCO SANTANDER. 99

4.3.6 SÍNTESE DAS PRÁTICAS DE TREINAMENTO E DESENVOLVIMENTO ....... 102 4.4 GEST ÃO DE DESEMPENHO E AVALIAÇÃO, SISTEMA DE PAGAMENTO E RECOMPENSA 105

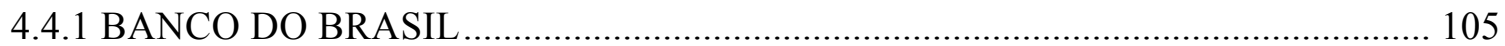

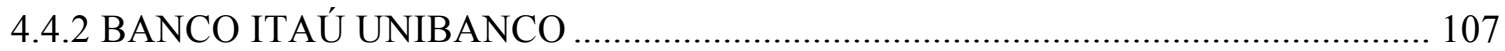

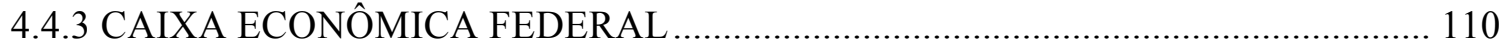

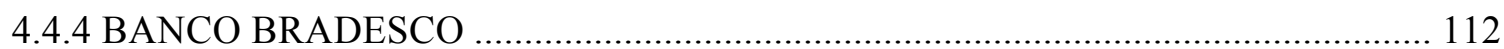

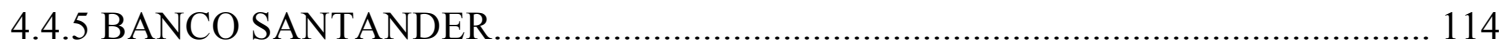

4.4.6 SÍNTESE DAS PRÁTICAS DE SISTEMA DE PAGAMENTO E RECOMPENSA E GESTÃO DE DESEMPENHO E AVALIAÇÃO............................................................. 115

4.5 SAÚDE, SEGURANÇA E QUALIDADE DE VIDA NO TRABALHO................... 119

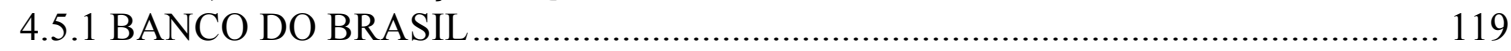

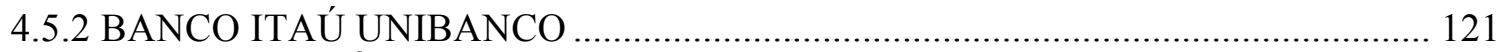

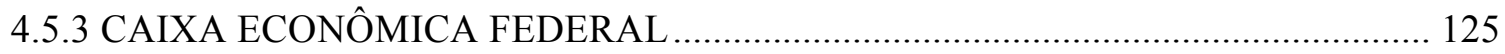

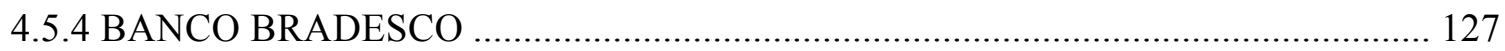

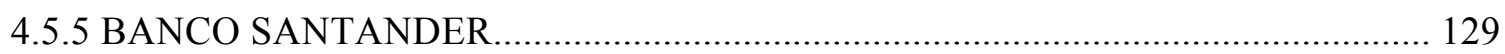

4.5.6 SÍNTESE DAS PRÁTICAS DE SAÚDE, SEGURANÇA E QUALIDADE DE VIDA

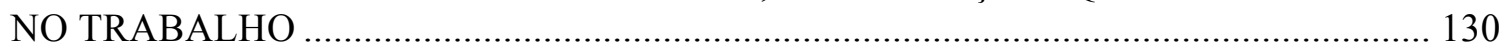

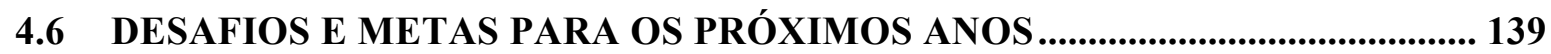

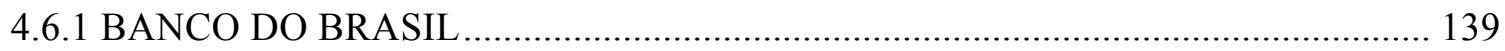

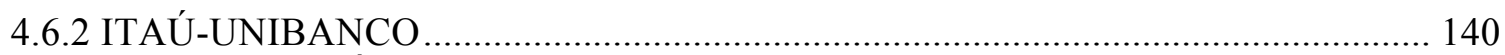

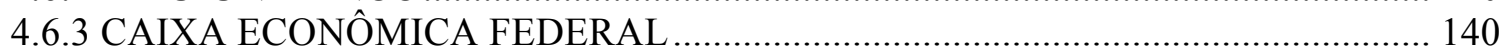

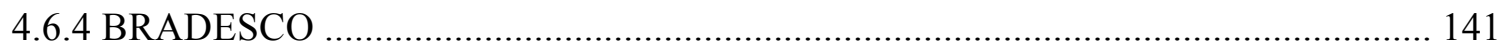

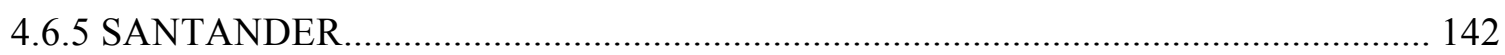

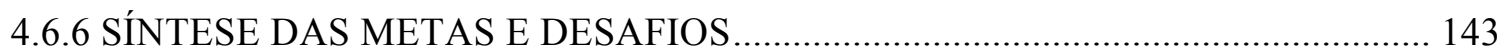

4.7 GESTÃO SUSTENTÁVEL DE PESSOAS NOS BANCOS ..................................... 144

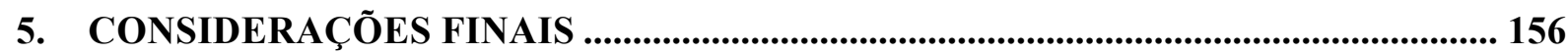

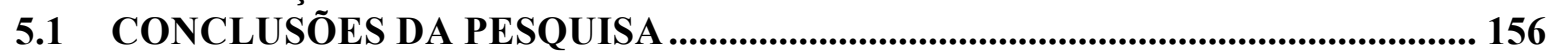

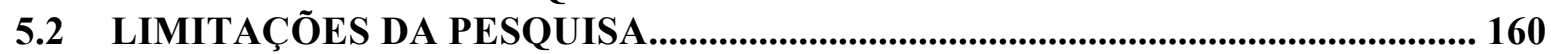

5.3 SUGESTÕES PARA OS ESTUDOS FUTUROS .............................................. 161

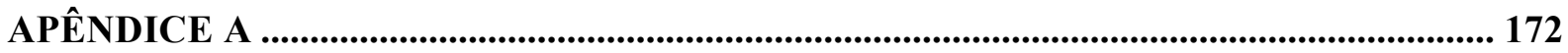




\section{INTRODUÇÃO E JUSTIFICATIVA}

Diante do aumento da pressão, por parte dos stakeholders, para que a empresas possuam uma atitude ética frente às questões ambientais e sociais, além do lucro, as empresas desenvolveram um interesse em investir em ações sustentáveis. No entanto, de acordo com Claro et al. (2008), até hoje elas encontram dificuldades em associar seus discursos e suas práticas gerenciais à luz da sustentabilidade.

Dentro do contexto das práticas de sustentabilidade, as questões sociais recebem destaque, uma vez que o papel dos stakeholders tanto internos quanto externos à organização é percebido como essencial para a manutenção das operações organizacionais no longo prazo.

Jabbour e Santos (2008) afirmam que é necessário um padrão de desenvolvimento que privilegie igualmente os aspectos sociais, econômicos e ambientais, e as organizações são responsáveis por iniciar as mudanças, como se fosse um ciclo vicioso. Declaram ainda que os conceitos relacionados ao desenvolvimento sustentável são amplos, e ao mesmo tempo pouco explorados no quesito prático para ajudarem as organizações a se tornarem sustentáveis.

Logo, atingir bons resultados nos pilares econômico, social e ambiental, que são interrelacionados e que se influenciam mutuamente, pode contribuir para o desenvolvimento sustentável no domínio político em que as organizações estão inseridas (DYLLICK e HOCKERTS, 2002; CHENG et al., 2010).

Igualmente, se uma organização quer ser sustentável em longo prazo, precisa investir para que todas as áreas de sua empresa estejam alinhadas com as diretrizes da sustentabilidade, tendo a gestão de pessoas como foco primordial para a realização dessas mudanças. Gerir as organizações em relação aos seus recursos humano-sociais, naturais e econômicos, envolvendo a sustentabilidade organizacional à área de gestão de pessoas é um grande desafio (EHNERT e HARRY, 2012).

A área de gestão de pessoas está inserida na dimensão social, que culmina em aspectos internos e externos; os internos são relativos à governança corporativa, motivação e incentivo aos funcionários, saúde e segurança e desenvolvimento do capital humano, dentre outros; já os externos, atividades não controversas, não corrupção ou cartel e comportamento ético (BAUMGARTNER e EBNER, 2010).

A crescente concorrência enfrentada com a globalização, requer um desenvolvimento do potencial interno das organizações, já que são as pessoas que mantêm o sistema administrativo em operação. Dessa forma, a gestão de pessoas passa a ser vista como vital no 
alcance da vantagem competitiva, inclusive no setor bancário brasileiro (SAVANEVICIEN E STANKEVICIUTE, 2012).

Diante de seu grande poder econômico e financeiro, onde os investimentos não se restringem apenas nos aspectos econômico, social externo e ambiental da sustentabilidade organizacional, esse setor foi eleito nesta pesquisa para ser analisado (GUIMARÃES FILHO e GOMES, 2010). Uma gestão sustentável deve ser capaz de modificar o risco de prejuízo às integridades físicas e mentais dos bancários, focando principalmente no aspecto social interno, ou seja, na preocupação com seus funcionários.

A importância desse setor e a justificativa de sua escolha está na elevada capilaridade geográfica no país. Além disso, com as inovações tecnológicas e os métodos de organizações trabalhistas, os bancários passaram por muitas transformações.

Diante dessas reestruturações, e consequentemente da função dos seus trabalhadores, estes se tornaram mais polivalentes e altamente pressionados para cumprir metas (SILVA e NAVARRO, 2012). Logo, lidar com paradoxos cria a necessidade de se olhar para a gestão de pessoas a partir de uma perspectiva mais a longo prazo (EHNERT, 2009).

Apesar de algumas práticas de gestão de pessoas já serem utilizadas nas empresas, como clima organizacional, pesquisas de bem-estar, qualidade de vida, elas não são medidas sistemáticas, e nem fazem parte de uma estratégia de gestão mais ampla, não se preocupando tão intensamente com a responsabilidade social interna (KRAMAR, 2014).

Advém daí a necessidade de integrar todas as atividades das empresas às melhorias organizacionais. A sustentabilidade necessita de um novo modo de agir das organizações, não sendo práticas isoladas voluntárias ou respostas às exigências dos stakeholders (VALENTE, 2012).

$\mathrm{Na}$ literatura e na prática, ainda existem lacunas entre o conceito de sustentabilidade organizacional e as estratégias adotadas para que ela seja implementada no dia-a-dia das operações, principalmente levando em consideração a visão sistêmica do negócio (CHENG et al., 2010).

Embora estudiosos estejam cada vez mais interessados na Gestão Sustentável de Pessoas, mais pesquisas são necessárias para dar forma a este conceito e desenvolver um guia de implicações práticas que sejam claras e objetivas para serem seguidas, ou seja, muitos trabalhos tem sido mais conceituais e menos de natureza exploratória (EHNERT et al., 2015).

Por meio dos subsistemas de Gestão de Pessoas poderá ser possível proporcionar apoio, tanto estratégico quanto operacional, integrando a área à sustentabilidade organizacional, ao mesmo tempo que produz resultados sinérgicos às instituições bancárias 
(JAMALI et al., 2015).

Logo, definir as ações dos subsistemas de gestão de pessoas pode auxiliar as organizações a equilibrarem seus investimentos tanto no âmbito econômico, quanto no ambiental e social externo e interno, de modo que esses aspectos integrem as estratégias e os objetivos das empresas.

Para Kramar (2014) a organização sustentável deve ter uma estrutura flexível com práticas de gestão de pessoas que constroem as capacidades de força de trabalho, prevê a tomada de decisão participativa (empowerment), gestão da diversidade, níveis elevados de saúde no local de trabalho e indicadores de segurança e desempenho que refletem preocupações éticas e os princípios da sustentabilidade.

Assim, por meio de uma triangulação de dados, utilizando os relatórios anuais ou de sustentabilidade dos bancos selecionados para análise nesta pesquisa (Banco do Brasil, Itaú Unibanco, Caixa Econômica Federal, Bradesco e Santander), os acórdãos trabalhistas finalizados no Tribunal Regional do Trabalho da $2^{\text {a }}$ Região de São Paulo no último ano (2014), e as informações do Sindicato dos Bancários e Financiários de São Paulo, Osasco e Região e da Federação Brasileira de Bancos, este trabalhou visou analisar as ações e iniciativas de gestão de pessoas dentro do setor bancário brasileiro. Para a verificação dessas iniciativas foram utilizadas a análise de conteúdo e a estatística descritiva, para organizar, sumarizar e identificar as ações.

Ao realizar um estudo com múltiplas fontes, o intuito foi encontrar um panorama mais completo acerca do paradoxo entre o que as empresas reportam e praticam, e o que realmente os trabalhadores vivenciam, já que os aspectos sociais internos não são tão explorados pelo setor. Além disso, há uma grande complexidade existente ao se analisar as práticas trabalhistas pela sustentabilidade.

Para contemplar as lacunas existentes na definição e delineamento da Gestão Sustentável de Pessoas, a metodologia sistêmica Softy System Methodology foi utilizada, a fim de se construir um quadro conceitual com ações abrangendo os subsistemas de Gestão de Pessoas que envolvam a sustentabilidade organizacional.

Assim, diante deste potencial a ser explorado na área, as contribuições teóricas trazidas neste trabalho estão no delineamento das categorias dos subsistemas de Gestão de Pessoas, mais recentes que as encontradas nas literaturas e no desenvolvimento do quadro conceitual com ações da Gestão Sustentável de Pessoas.

Dentro das contribuições metodológicas estão a análise das ações e iniciativas do setor bancário brasileiro, frente à esses subsistemas, bem como o exame das questões mais 
recorrentes nos acórdãos trabalhistas, identificando o panorama atual do setor frente suas iniciativas envolvendo a sustentabilidade organizacional. A ligação entre gestão sustentável de pessoas e análises de reclamações trabalhistas não estava clara na literatura até o momento.

Diante do que foi supracitado, a questão de pesquisa que moveu este estudo foi: a gestão de pessoas do setor bancário brasileiro está alinhada aos modelos de Gestão Sustentável de Pessoas? Como questão complementar a esta, espera-se entender melhor: quais as principais queixas apresentadas pelos trabalhadores deste setor?

\subsection{OBJETIVOS DA PESQUISA}

Este trabalho tem como objetivo principal analisar as iniciativas da gestão sustentável de pessoas no setor bancário brasileiro, confrontando-as com as queixas trabalhistas registradas.

Para alcançar o objetivo proposto, são descritos os quatro objetivos específicos:

1. Identificar as práticas de gestão de pessoas reportadas pelos bancos em seus relatórios anuais ou de sustentabilidade;

2. Levantar as ações trabalhistas movidas pelos trabalhadores do setor bancário finalizadas no ano de 2014;

3. Identificar a visão do Sindicato dos Bancários e Financiários de São Paulo, Osasco e Região e da Federação Brasileira de Bancos (Febraban) quanto às práticas de gestão de pessoas praticadas pelos bancos;

4. Propor um quadro da gestão sustentável de pessoas no setor bancário brasileiro.

\subsection{ORGANIZAÇÃO DO CONTEÚDO}

Este trabalho está dividido em quatro seções. A primeira é uma revisão de literatura encontrada sobre Caracterizações Conceituais de Sustentabilidade, Sustentabilidade e Gestão de Pessoas, Modelos de Gestão Sustentável de Pessoas, os Subsistemas de Gestão de Pessoas, e enfim, sobre o Setor Bancário Brasileiro. Na segunda parte tem-se os materiais e métodos utilizados, classificando a pesquisa, elencando as etapas, coleta e tratamento de dados e as proposições que nortearam o trabalho. A parte três mostra os resultados encontrados e a última parte traz as considerações finais, limitações do estudo e sugestão para os próximos trabalhos. 


\section{REVISÃO DE LITERATURA}

Esse capítulo foi agrupado em tópicos centrais a fim de dar suporte às discussões finais.

\subsection{CARACTERIZAÇÕES CONCEITUAIS DE SUSTENTABILIDADE}

Em se tratando de organizações visando ser sustentáveis, nas últimas décadas, o contexto corporativo passou a contar com a relevância da temática. Faria e Sauerbronn (2008) afirmam que a importância deste tema se deu por fatores como a aceleração da globalização, os grandes escândalos envolvendo corporações e o aumento de poder político e econômico das mesmas.

Lemme (2010) traz que, ao emergir a Revolução Industrial no século XVIII, o capital industrial foi o que recebeu maior atenção, sugerindo que havia uma abundância de disponibilidade nos recursos naturais e humanos. Desta forma não haveria espaço para se atentar a esses recursos como fatores restritivos ao desempenho financeiro/organizacional.

A discussão sobre as questões ambientais e as relações com ações empresariais foi iniciada na década de 1960, após algumas catástrofes ambientais terem ocorrido, principalmente por má administração de empresas. Esses fatores levaram a abertura de discussões e a busca por soluções para modificar esse cenário (JUNQUEIRA et al., 2011).

O lançamento do livro Primavera Silenciosa, por Rachel Carson em 1962, foi um marco muito importante, pois apresentou a inquietação dos cientistas e estudiosos da época, no que tange a preservação dos recursos naturais do planeta, questionando a responsabilidade da ciência e os limites dos avanços tecnológicos (JACOBI, 2005; JUNQUEIRA et al., 2011).

Dentre as iniciativas que estabeleceram o início desse movimento frente às consequências do crescimento acelerado da população mundial versus os recursos naturais limitados, está a discussão em Estocolmo, Suécia, no ano de 1972. Denominado I Conferência da Organização das Nações Unidas sobre o Meio Ambiente e o Homem, foi onde adveio a elaboração do The limits to Growth - ou os Limites do Crescimento - um documento relacionado aos temas ambientais de preservação e o uso dos recursos naturais em esfera global (VAN BELLEN, 2004).

Após essa Conferência outro marco importante ocorreu em 1987, conhecido como Relatório de Brundtland, nome advindo da então primeira-ministra da Noruega, Gro Harlem Brundtland, chefe da comissão. Traduzido como Nosso Futuro Comum, esse relatório trouxe a concepção da definição de desenvolvimento sustentável, que é aquele: 'capaz de satisfazer 
as necessidades das gerações atuais, sem comprometer a capacidade das gerações futuras' (UNITED NATIONS, 1987). Tal relatório revolucionou a discussão sobre o tema e se tornou conhecido mundialmente (TOGASHI e HACON, 2012; JUNQUEIRA et al., 2011).

É notória a intensificação de iniciativas acerca desse tema ao final do século XX. A ECO-92 foi sem dúvida um evento de grande relevância, reunindo chefes de estado de todos os continentes, lançando o conceito de ecoeficiência e sendo ponto inicial para a Agenda 21 e o Protocolo de Quioto. Foi realizada no Rio de Janeiro, e visou comprometer os líderes mundiais e das empresas quanto à sustentabilidade mundial (JUNQUEIRA et al., 2011).

Junqueira et al. (2011) também trazem que algumas iniciativas locais brasileiras intensificaram esse quadro de debates, marcando uma mudança na gestão empresarial a partir dos anos 90. Novas leis, a criação do Instituto Brasileiro de Análises Sociais e Econômicas (IBASE), a Agenda 21 brasileira, Instituto Ethos, entre outras, foram destaques desse movimento no país. A Figura 1, a seguir, traz uma síntese da evolução das iniciativas realizadas nacional e mundialmente frente à sustentabilidade.

Figura 1. Evolução de algumas iniciativas acerca da sustentabilidade

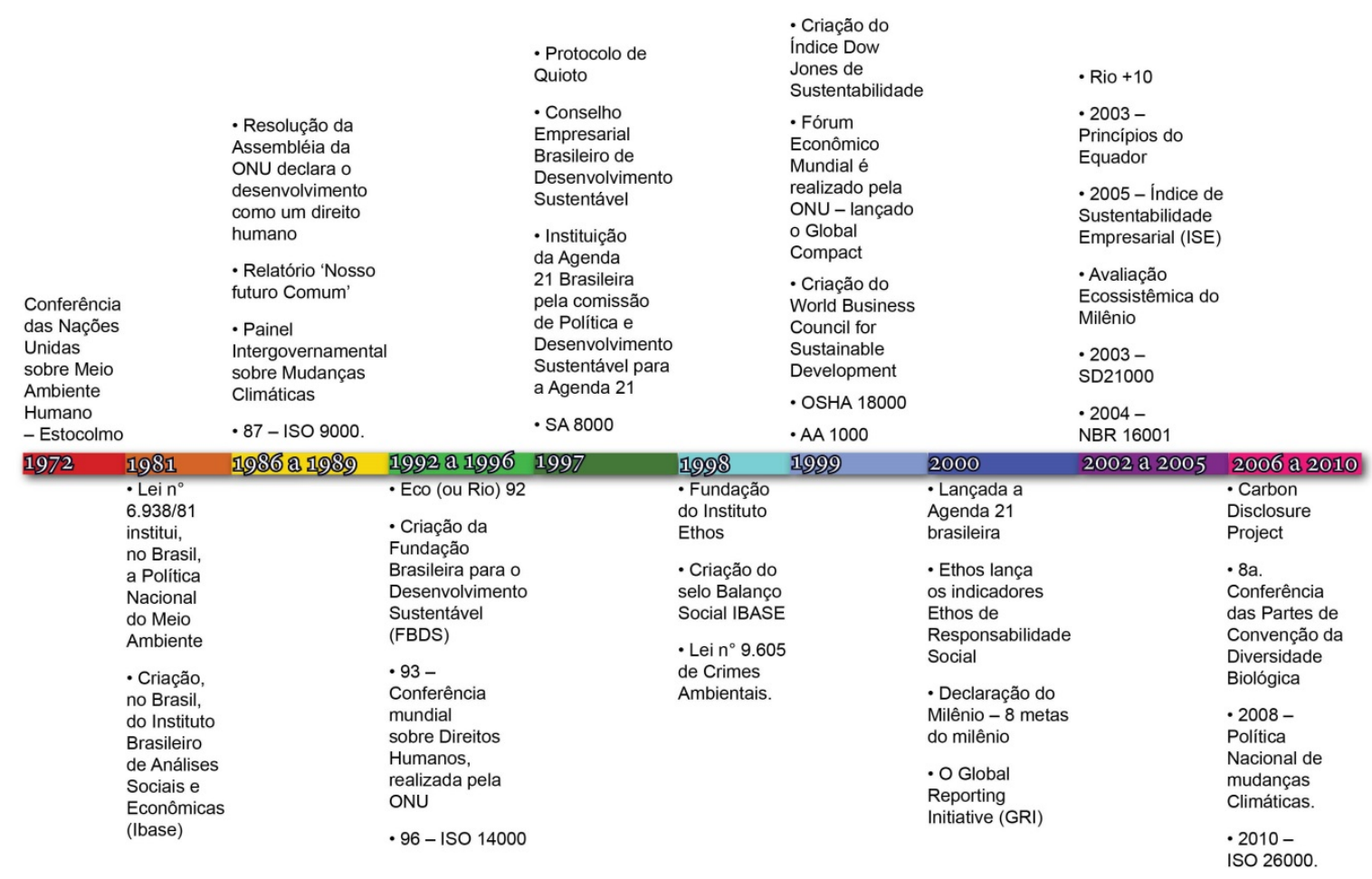

Fonte: Adaptado de Junqueira et al. (2011). 
As iniciativas acerca da sustentabilidade permitiram uma reflexão maior dentro das organizações. Com a discussão a nível mundial sobre a temática, tornou-se necessário repensar nas ações praticadas pelas empresas e a importância que as pessoas têm para agirem em prol de uma sustentabilidade organizacional, como descrito no próximo item.

\subsection{SUSTENTABILIDADE ORGANIZACIONAL E GESTÃO DE PESSOAS}

O conceito de sustentabilidade organizacional parte da percepção de que ao exercer suas atividades, as organizações consomem não só recursos financeiros, mas também recursos ambientais e sociais, que em muitos casos, são escassos. Tal constatação fez surgir em 1999, através de Elkington, o conceito do Triple Bottom Line - TBL, indicando que a sustentabilidade organizacional depende do relacionamento dos três pilares (econômico, social e ambiental).

A difusão do TBL decorreu diretamente da necessidade de equilíbrio entre os pilares. A partir da conhecida expressão bottom line utilizada pelos profissionais de finanças para designar o resultado líquido de uma empresa, o termo TBL passou a indicar a interação entre os resultados financeiros, ambientais e sociais na mensuração do desempenho organizacional (LEMME, 2010).

Neste contexto, para atingir a sustentabilidade, as organizações devem apresentar bons resultados em seus capitais econômico, social e ambiental - pilares estes inter-relacionados e que se influenciam mutuamente - enquanto contribuem para o desenvolvimento sustentável em seu domínio político (DYLLICK e HOCKERTS, 2002; CHENG et al., 2010).

Não obstante, a consideração dos dois fatores é importante para a implementação da sustentabilidade organizacional. Primeiramente, não basta realizar melhorias somente incrementais, é necessária uma mudança cultural, ou seja, a sustentabilidade organizacional precisa ser sistematicamente integrada a todas as atividades organizacionais. De acordo com Valente (2012), a sustentabilidade necessita representar um novo modo de agir da organização e não apenas ser entendida como práticas isoladas voluntárias e respostas às exigências dos stakeholders.

E segundo, para se pensar em sustentabilidade organizacional é imprescindível reconhecer o papel das pessoas e sua autonomia frente ao trabalho, além de reconhecer e valorizar a rede de relacionamentos pessoais da qual uma decisão organizacional é dependente e sofre influência (MUNCK, BORIM-SOUZA e ZAGUI, 2012).

Em geral, a sustentabilidade organizacional refere-se às atividades das organizações, e cada empresa apresenta um diferente nível de adesão à esse conceito e em suas práticas. Esses 
níveis são descritos pelos autores como (van MARREWIJK, 2003, p. 102-103; MUNCK e BORIM-SOUZA, 2009, p.197):

1. Pré-sustentabilidade organizacional: nesse nível não há intenção de se alcançar a sustentabilidade organizacional. Algumas ações podem ser denominadas como sustentáveis, se houver exigência externa, ou pelos consumidores, ou advindos de legislação.

2. Sustentabilidade organizacional em conformidade com a legislação: nesse nível, a partir dos limites previstos por normatizações legais, a provisão do bem-estar para a sociedade é levada em consideração. As organizações respondem a demandas de caridade e reivindicações de outros atores sociais. Para as organizações desse nível, a sustentabilidade é percebida como algo imposto, uma obrigação ou um comportamento que deve ser correto.

3. Sustentabilidade organizacional orientada pelo lucro: a integração dos aspectos sociais, éticos e ecológicos junto às atividades empresariais, serão realizadas se houver retorno financeiro para a organização. Será promovida apenas se for rentável.

4. Sustentabilidade organizacional consciente: neste nível os três aspectos são colocados no mesmo patamar de importância. A motivação para a sustentabilidade organizacional está pautada no potencial humano, na responsabilidade social das empresas e no cuidado com o Planeta.

5. Sustentabilidade organizacional sinérgica: neste nível a busca por soluções elaboradas e funcionais, que criem valor nos três âmbitos ocorre. Este tipo de performance é evidenciado por índices de desempenhos organizacionais, onde há ganho mútuo a todos stakeholders. A motivação para a sustentabilidade é a importância dela para o progresso da empresa.

6. Sustentabilidade organizacional holística: neste nível a sustentabilidade organizacional está extremamente integrada e embutida em cada um dos aspectos ambiental, social e econômico. Objetiva contribuir para a qualidade, manutenção e continuação da vida de todos os seres e instituições, tanto no presente quanto no futuro. A motivação nesse nível é que a sustentabilidade é vista como única alternativa de resposta à crise provocada no meio ambiente, o que torna cada pessoa e cada organização responsável universal para todos os outros seres vivos da Terra (van MARREWIJK, 2003, p. 102-103; MUNCK e BORIM-SOUZA, 2009, p.197). 
Alguns modelos emergentes de Gestão de Pessoas vem demonstrando a importância da área em encontrar formas de gerir organizações sustentavelmente em relação aos seus recursos humano-sociais, naturais e econômicos (EHNERT e HARRY, 2012).

A teoria do Strategic Human Resources Management (SHRM) é um conceito que foi desenvolvido no final dos anos 70 e 80 em uma tática de gerir funcionários num ambiente cada vez mais mutável, incerto e turbulento (KRAMAR, 2014).

Green et al. (2006) afirmam que uma organização a apresenta quando a função da gestão de pessoas é verticalmente alinhada com a missão e os objetivos da organização, e horizontalmente integrada com as outras funções organizacionais. O impacto direto da SHRM é no desempenho organizacional de maneira positiva e significativa, além do desempenho individual, comprometimento organizacional e satisfação no trabalho que são outros aspectos influenciados.

Outro modelo que vem sendo explorado por Jabbour et al. (2013), é o Green Human Resources Management (Green HRM), que traz que equipes verdes são um fator essencial para implementar e melhorar as abordagens e práticas de gestão ambiental nas organizações.

A incorporação de preocupações ambientais ou a inserção da gestão verde geralmente ocorre através de alterações nas técnicas dos processos ou produtos. O papel da área de Gestão de Pessoas se dá em alinhar suas diversas práticas aos objetivos do Green HRM (TEIXEIRA et al., 2012). Vickers (2005) também apresenta a importância da área em incluir no âmbito organizacional os postulados da sustentabilidade, sendo uma função de grande potencial de modificação.

E Renwick et al. (2013) alegam que as práticas Green HRM são susceptíveis de melhorar o bem-estar do empregado no local de trabalho, através da melhoria do ambiente de trabalho e da satisfação das necessidades de uma crescente força de trabalho consciente ambientalmente.

Diante dos stakeholders, as organizações podem planejar e executar a estruturação de uma gestão ambiental, conforme suas necessidades, havendo diferentes níveis de práticas. Algumas pesquisas realizadas sobre a temática (SILVA et al, 2009; ABREU, 2009; JABBOUR, 2010; JABBOUR et al., 2012), apresentaram três estágios dessas ações - reativo, preventivo e proativo - descritos a seguir no Quadro 1. 
Quadro 1 - Principais características dos diferentes níveis de estágio da gestão verde

\begin{tabular}{|c|c|c|}
\hline ESTÁGIO & NOME & CARACTERÍSTICAS \\
\hline \multirow{4}{*}{1} & \multirow{4}{*}{ Reativo } & Este é o estágio menos avançado da gestão verde \\
\hline & & $\begin{array}{l}\text { Organizações nesse estágio tendem a cumprir apenas a legislação e os avanços das } \\
\text { normas ambientais. }\end{array}$ \\
\hline & & $\begin{array}{l}\text { O sistema de gestão verde foca em evitar os problemas ambientais, e ela tende a ter } \\
\text { pouca autoridade na estrutura das organizações. }\end{array}$ \\
\hline & & A empresa não se envolve em atividades externas sobre o tema ambiental. \\
\hline \multirow{4}{*}{2} & \multirow{4}{*}{ Preventivo } & $\begin{array}{l}\text { Nesta fase, a organização procura otimizar o uso de recursos naturais através da } \\
\text { ecoeficiência e da aplicação dos 3R's (Reduzir, Reutilizar e Reciclar). }\end{array}$ \\
\hline & & A questão ambiental começa a ser discutida pelas áreas da organização. \\
\hline & & A área da gestão verde se torna mais proeminente na estrutura organizacional. \\
\hline & & Algumas ações de gestão verde externas são iniciadas. \\
\hline \multirow{4}{*}{3} & \multirow{4}{*}{ Proativo } & Este é o estágio final da gestão verde. \\
\hline & & $\begin{array}{l}\text { A questão ambiental é um elemento fundamental na estratégia de negócio e cria } \\
\text { vantagens competitivas. }\end{array}$ \\
\hline & & $\begin{array}{l}\text { Nesta fase, a gestão verde é ativa e suas ações são integradas às demais áreas da } \\
\text { organização. }\end{array}$ \\
\hline & & $\begin{array}{l}\text { A empresa começa a implementar metodologias para reduzir os impactos da cadeia de } \\
\text { produção e do ambiente interno, como a Avaliação do Ciclo de Vida e a seleção dos } \\
\text { fornecedores com base em critérios ambientais. }\end{array}$ \\
\hline
\end{tabular}

Fonte: Adaptado de Teixeira, Jabbour e Jabbour, 2012, p. 319.

Ehnert et al. (2015) alega que com a crescente consciência pública sobre a importância das organizações na contribuição para o desenvolvimento sustentável, tem havido um maior incentivo para que as empresas comuniquem aos seus stakeholders suas ações em sustentabilidade. Ao mesmo tempo, a gestão sustentável de pessoas tem ganhado espaço na literatura acadêmica, unindo a gestão de pessoas aos conceitos da sustentabilidade organizacional.

Logo, lidar com paradoxos existentes entre os pilares da sustentabilidade cria a necessidade de se olhar para a gestão de pessoas a partir de uma perspectiva mais a longo prazo (EHNERT, 2009). A função da área está em ajudar tanto na estratégia quanto na implementação da sustentabilidade organizacional (COHEN et al., 2012).

Diante disso, uma discussão em torno dos conceitos sobre um modelo de gestão sustentável de pessoas - GSP (termo utilizado neste trabalho para a tradução de Sustainable Human Resources Management) foi iniciada. A literatura sobre este tema desenvolveu-se durante a última década e representa uma tentativa de lidar com a relação entre as práticas de gestão de pessoas e resultados que vão além dos resultados predominantemente financeiros (KRAMAR, 2014). 
A autora ainda traz que essa literatura é fragmentada, diversa e repleta de dificuldades. Não existe uma definição exata. Os escritos sobre gestão sustentável de pessoas diferem em termos da ênfase dada a determinados resultados internos e externos.

O termo pode ser conceituado como a utilização de ferramentas de gestão de pessoas capazes de criar uma força de trabalho com valores como confiança, habilidades e motivação, a fim de alcançar um rentável triple bottom line (COHEN et al., 2012).

Jamali, Dirani e Harwood (2015) acreditam que a função da gestão de pessoas poderá proporcionar apoio, tanto estratégico quanto operacional para a implementação da responsabilidade social corporativa (termo usado em alguns trabalhos como equivalente para sustentabilidade organizacional) e que uma integração mais estreita entre os dois pode produzir resultados sinérgicos. Segundo os autores, existe uma complementação entre as duas áreas já que a responsabilidade social corporativa é tradicionalmente focada externamente, enquanto a gestão de pessoas é focada internamente.

Nesta visão a Gestão Sustentável de Pessoas pode ser apoiada pelos modelos de Green HRM e de Strategic HRM, englobando as práticas com foco no ambiental, ao mesmo tempo que alinha a estratégia organizacional ao tripé da sustentabilidade nas ações empresariais.

Ehnert (2006) entende a Gestão Sustentável de Pessoas como o comportamento padrão de implantar programas e atividades de gestão de pessoas destinados a permitir um equilíbrio entre a realização do objetivo organizacional e a reprodução da base de Gestão de Pessoas ao longo do tempo, e para controlar o impacto negativo sobre esta mesma base.

Os três principais objetivos da Gestão Sustentável de Pessoas são: (i) equilibrar ambiguidades e dualidades entre eficiência e sustentabilidade no longo prazo; (ii) sustentar, desenvolver e reproduzir uma base organizacional de recursos humanos e sociais, baseado num relacionamento de troca mútua; e (iii) avaliar os efeitos negativos das atividades de Gestão de Pessoas na base (pessoas) e sobre as fontes (EHNERT, 2006).

Kramar (2014), por sua vez, acredita que uma organização sustentável tem uma estrutura flexível com práticas de Gestão de Pessoas que constroem as capacidades de força de trabalho, prevê a tomada de decisão participativa, gestão da diversidade, níveis elevados de saúde no local de trabalho e indicadores de segurança e desempenho que refletem preocupações éticas e os princípios da sustentabilidade.

Algumas práticas de GSP, como as sugeridas por Cohen et al. (2012, p.29), se pautam em: “(i) desenhar um sistema de Gestão de Pessoas que reflita equidade, desenvolvimento e bem-estar, contribuindo para a saúde a longo prazo e a sustentabilidade tanto para os funcionários internos, quanto para as comunidades externas; (ii) enfatizar a segurança do 
emprego a longo prazo para evitar perturbações aos empregados, suas famílias e a comunidade".

Como resultado das discussões em torno de um modelo de gestão sustentável de pessoas espera-se ganhos em sentido de competitividade. Fazendo um paralelo entre gestão sustentável, práticas de Gestão de Pessoas e visão baseada em recursos (RBV), Jamali, Dirani e Harwood (2015) afirmam que uma gestão sustentável de pessoas pode contribuir para o fortalecimento da estratégia da empresa em ser sustentável, pois, enquanto as manifestações externas de responsabilidade social corporativa são fáceis de imitar pelos concorrentes.

As dinâmicas tácitas e causalmente ambíguas internas, os padrões de trabalho em equipe e a coordenação na elaboração de estratégias são elementos diferenciadores e fornecem uma fonte de inovação competitiva sustentável como sugerida através da perspectiva da RBV. Esta configuração pode produzir capacidades únicas para a empresa e traduzir-se em uma série de resultados valorosos de longo prazo para a organização.

Orientando as organizações para a essência, há que se reconhecer a importância do valor e da qualidade das pessoas dentro delas, procurando manter as organizações e principalmente a área de Gestão de Pessoas como meio de sobrevivência no futuro (EHNERT, 2009).

Atualmente, segundo Cohen et al. (2012) existem alguns frameworks que apoiam a estratégia de sustentabilidade empresarial, mas apenas algumas são abrangentes, globais e aplicáveis em todas as organizações. Os principais são: Pacto Global das Nações Unidas, as Diretrizes da Organização para a Cooperação e Desenvolvimento Econômico para Empresas Multinacionais, o Padrão ISO26000, SA8000 e o Global Reporting Initiative (GRI), sendo este o mais utilizado (cerca de 6 mil empresas por ano).

Encontrar formas de gerir organizações sustentavelmente em relação aos seus recursos humanos/sociais, naturais e econômicos é um grande desafio para a Gestão de Pessoas frente a internacionalização, globalização e a resistência à ela (EHNERT e HARRY, 2012).

O modelo de Van Marrewijk (2003) para sustentabilidade organizacional, mesmo sendo mais geral e abrangendo todas as áreas das empresas, pode ser adaptado para a Gestão Sustentável de Pessoas, gerando subsídios para analisar o nível de aderência da sustentabilidade organizacional em suas ações.

O Quadro 2 a seguir sintetiza os principais aspectos dos diferentes modelos de Gestão de Pessoas abordados neste trabalho. 
Quadro 2. Quadro síntese dos modelos emergentes de Gestão de Pessoas

\begin{tabular}{|c|c|c|}
\hline STRATEGIC HRM & GREEN HRM & $\begin{array}{l}\text { GESTÃO SUSTENTÁVEL DE } \\
\text { PESSOAS }\end{array}$ \\
\hline Principais aspectos: & Principais aspectos: & Principais aspectos: \\
\hline $\begin{array}{l}\text { Os interesses dos agentes } \\
\text { envolvidos (stakeholders) passam a } \\
\text { ser levados em consideração nas } \\
\text { organizações. A valorização das } \\
\text { contribuições individuais para o } \\
\text { resultado final da organização } \\
\text { passam a ser focados. }\end{array}$ & $\begin{array}{l}\text { O meio-ambiente passa a se } \\
\text { relacionar às relações humanas, } \\
\text { sendo considerado um grande foco } \\
\text { a ser trabalhado. }\end{array}$ & $\begin{array}{l}\text { O triple bottom line passa a ser } \\
\text { fundamental para a manutenção da } \\
\text { empresa no longo prazo, sendo uma } \\
\text { vantagem competitiva. }\end{array}$ \\
\hline
\end{tabular}

Fonte: Elaborado pela autora.

Assim, tanto a sustentabilidade organizacional quanto as práticas da área de gestão de pessoas voltadas a essa temática, se tornam fatores primordiais para a geração de valor das organizações e suas possíveis vantagens competitivas frente aos concorrentes. Para isso, uma literatura embasando a gestão de pessoas e seus subsistemas, estão apresentadas no próximo item.

\subsection{SUBSISTEMAS DE GESTÃO DE PESSOAS}

Uma organização sustentável tem uma estrutura flexível e práticas de Gestão de Pessoas que constroem as capacidades de força de trabalho, prevê a tomada de decisão participativa, gestão da diversidade, níveis elevados de saúde no local de trabalho e indicadores de segurança e desempenho que refletem as preocupações éticas (KRAMAR, 2014).

Jackson et al. (2011) reconheceram que as práticas de Gestão de Pessoas irão influenciar o grau em que as pessoas são atraídas para trabalhar em alguma organização, bem como comprar seus serviços e produtos. Logo, percebe-se a importância de investir no desenvolvimento social e humano das organizações.

Para isso, o setor de Gestão de Pessoas possui um conjunto de partes relacionadas entre si, denominadas subsistemas, que correspondem às políticas e práticas utilizadas para gerir pessoas numa organização.

Os gerentes devem rever todas as funções básicas da Gestão de Pessoas relacionadas a proteção dos direitos dos trabalhadores, a igualdade de oportunidades nos empregos, recrutamento, treinamento, desenvolvimento, facilidades das instalações, saúde, segurança e bem-estar, remuneração, cultura organizacional e comunicação (COHEN et al., 2012). 
Além disso, para uma verdadeira liderança sustentável é necessário que se trabalhem com as organizações para ajudá-las a incorporarem as novas competências e formas de pensar necessárias para conduzir as organizações para a sustentabilidade.

Renwick, Redman e Maguire (2013) trazem em seu trabalho a divisão dos subsistemas de Gestão de Pessoas como: Recrutamento e Seleção (R\&S), Treinamento e Desenvolvimento (T\&D), Sistemas de Pagamento e Recompensa (SPR) e Gestão de Desempenho e Avaliação (GDA).

Já Greenwood (2002) e Kramar (2014) tratam da importância das questões da Saúde, Segurança e Qualidade de vida no Trabalho (SSQVT). Logo, os subsistemas considerados como norteadores deste trabalho estão elencados na Figura 2 a seguir.

Figura 2. Subsistemas de Gestão de Pessoas

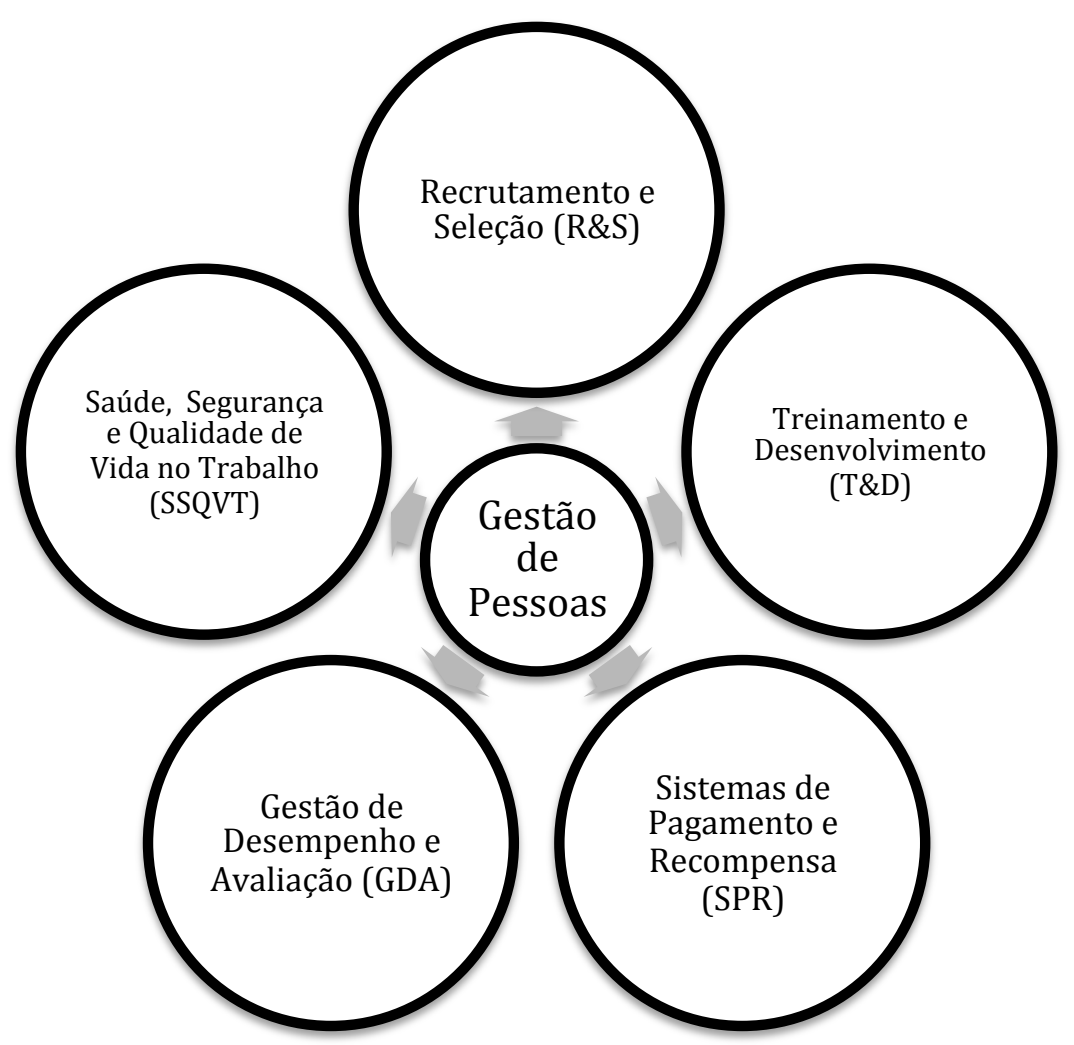

Fonte: Adaptado de Renwick, Redman e Maguire (2013), Greenwood (2002), Kramar (2014).

A GSP parte do pressuposto que tanto os eixos econômicos e ambientais quanto o social, devem estar inseridos nas organizações e em todas as suas práticas. Para embasar as análises deste trabalho, os subsistemas de Gestão de Pessoas estão descritos a seguir.

\subsubsection{RECRUTAMENTO E SELEÇÃO (R\&S)}

O Subsistema de Recrutamento e Seleção (R\&S) é responsável por buscar candidatos adequados à determinada vaga em uma empresa. É um processo onde se almeja os melhores 
profissionais que atendam aos requisitos demandados ao perfil da vaga (LIMONGI-FRANÇA e ARELLANO, 2002).

Recrutar e Selecionar pessoas são práticas tão antigas quanto a organização social dos povos. A preocupação sempre foi avaliar pessoas a fim de selecionar as mais aptas para determinadas tarefas. $\mathrm{O}$ foco desses processos começou nas forças militares, não havendo critérios apurados na escolha, ou seja, eles eram exclusivamente aspectos anatômicos, como força física para selecionar os melhores soldados. Hoje outros aspectos são considerados, dependendo do objetivo de cada vaga (CARVALHO et al., 2008).

A diferença de recrutamento e seleção, é que o primeiro visa aumentar a quantidade e diversidade de candidatos concorrendo a uma determinada vaga, já a seleção visa selecionar entre essa diversidade de opções, qual o candidato mais propício aos critérios da vaga disponível (JABBOUR, SANTOS e NAGANO, 2008).

A prática contemporânea de $R \& S$ tem como papel central a ideia de competências, que teve Fayol como embrionário dessa percepção ao afirmar sobre a importância das capacidades que constituem um valor do pessoal da empresa. Ele criou categorias, atribuindo o grau de importância de cada capacidade, sendo de caráter abrangente e cientificista, e ressaltando pontos que até hoje geram estudos e buscam novas perspectivas a serem exploradas (CARVALHO et al., 2008).

A primeira etapa de um processo de recrutamento consiste na precisão da decisão do perfil profissional desejado, normalmente descrito pelo responsável da área da vaga ofertada. A próxima etapa é a divulgação da vaga, que normalmente ocorre em mídias sociais, universidades, entre outros meios. Atualmente as inscrições ocorrem com mais frequência via internet, consistindo em preenchimentos de formulários, cadastro do currículo no website da organização ou na terceirizada responsável pelo R\&S (ALVES e ALMEIDA, 2009).

Em seguida, há uma prova de conhecimentos lógicos e de língua estrangeira, e os candidatos que superam essas fases vão para as dinâmicas em grupo. Sendo presencialmente, o usual é a solução de um case, com um problema que deve ser tratado por todos os grupos. É nesta etapa que os avaliadores tentam absorver as competências comportamentais de cada indivíduo, dependendo do modo como ele se adapta e interage aos outros integrantes (ALVES e ALMEIDA, 2009).

Após as dinâmicas em grupo, o número de candidatos fica bem reduzido, partindo então para a fase de entrevista com os gestores responsáveis pela área. Assim, o candidato que mais se adequar ao que foi exigido será o selecionado (ALVES e ALMEIDA, 2009). 
Souza et al. (2015) afirmam que há um investimento em recrutamentos mais estruturados para atrair profissionais mais qualificados e também no desenvolvimento de novas competências, para que os colaboradores possam trabalhar de forma flexível e polivalente.

Em uma empresa que visa ser sustentável organizacionalmente, todas essas etapas de recrutamento e seleção devem conter elementos capazes de avaliar a sintonia do candidato aos âmbitos sociais, ambientais e econômicos que o TBL proporciona.

Renwick et al. (2013) descreveram algumas ações para a gestão verde, abrangendo o processo de recrutamento e seleção mais voltado para o aspecto ambiental. A partir da sua base, as ações a seguir foram adaptadas, com a inclusão dos âmbitos social e econômico, que são os aspectos trazidos junto ao ambiental nas teorias da sustentabilidade organizacional e da gestão sustentável de pessoas:

Quadro 3 - Subsistemas de Gestão de Pessoas - Recrutamento e Seleção

\begin{tabular}{|c|c|}
\hline SUBSISTEMA & AÇ ÕES \\
\hline \multirow{5}{*}{$\mathbf{R} \& \mathbf{S}$} & Descrições de cargos e de vagas com itens englobando gestão ambiental, social, e econômica. \\
\hline & $\begin{array}{l}\text { Candidatos que se utilizam de questões sociais, ambientais e econômicas para escolha do } \\
\text { local para trabalhar. }\end{array}$ \\
\hline & Comunicação da marca e ações de sustentabilidade organizacional pela empresa. \\
\hline & Escolha de parceiros em R\&S conscientes da sustentabilidade organizacional. \\
\hline & Utilização de questões sociais, ambientais e econômicas durante o processo seletivo. \\
\hline
\end{tabular}

Fonte: Adaptado de Renwick, Redman e Maguire (2013).

Estudos sugerem que empresas com alto desempenho, com uma gestão eficaz de pessoas, estão fortemente ligadas à sua capacidade de atrair e reter talentos, superando seus concorrentes. A base da competitividade das organizações está em um número de fatores de gestão de pessoas, como a formação e as oportunidades de treinar e desenvolver os talentos, a abertura entre os colegas de trabalho, o grau de pró-atividade no planejamento de Gestão de Pessoas, principalmente se incluírem os preceitos da sustentabilidade organizacional em suas estratégias (HILTROP, 1999).

É muito importante que os profissionais se identifiquem com os valores da empresa, assim como a reputação e a imagem da mesma (RENWICK, REDMAN e MAGUIRE, 2013). Os profissionais de recrutamento e seleção também devem estar atentos às mudanças no cenário empresarial que vem ocorrendo, como no Quadro 4 a seguir (CARVALHO et al., 2008, p.33): 
Quadro 4 - Comparação entre cenários organizacionais

\begin{tabular}{|l|l|}
\hline \multicolumn{1}{|c|}{ De } & \\
\hline Pouca competitividade & Competição global \\
\hline Estabilidade & Mudanças \\
\hline Previsibilidade & Incertezas \\
\hline Individualismo & Parceria \\
\hline Rigidez hierárquica & Flexibilidade \\
\hline Poder centralizado & Empowerment \\
\hline Relação ganha x perde & Relação ganha x ganha \\
\hline Segurança no emprego & Empregabilidade \\
\hline Diploma & Educação continuada \\
\hline Carreira definida pela empresa & Carreira como responsabilidade do indivíduo \\
\hline Cargos & Espaço Organizacional \\
\hline Submissão & Proatividade \\
\hline
\end{tabular}

Fonte: Adaptado Carvalho et al. (2008, p. 33).

O grande desafio de recrutar e selecionar pessoal hoje é que as mudanças são constantes, e a velocidade em que elas ocorrem é cada vez mais rápida. O objetivo deve ser ultrapassar as demandas, sob probabilidade de se tornarem defasados em curto espaço de tempo. Não se deve tentar selecionar apenas o melhor candidato, mas sim aquele com potencial de se desenvolver. As organizações devem estar preparadas para competir com competência, não sendo aceitável que elas errem por conta de processos seletivos mal feitos (CARVALHO et al., 2008).

Além disso, é importante ressaltar a questão das diversidades. Devem-se respeitar as pessoas com necessidades especiais, a equidade entre os gêneros, as diferenças raciais, e não agir reativamente, apenas porque existe a obrigação advinda da legislação. Estas questões também devem ser respeitadas durante o processo de recrutamento e seleção.

Com as transformações que o mundo de trabalho vem sofrendo, é vital perceber, compreender e aproveitar as diferenças entre as pessoas, visando a vantagem competitiva. A sociedade brasileira é muito heterogênea, devido às heranças culturais, desse modo, as organizações devem lidar com o desafio do hibridismo (PEREIRA e HANASHIRO, 2010).

Desde a década de 80 a diversidade passou a ser vista não apenas como um retrato de minorias, mas sim como um enriquecimento do corpo social que proporciona experiências e perspectivas de diversos grupos. A partir da década de 90, a expressão "diversidade humana" passou a ser utilizada para as pessoas que são alvo de opressão diante de critérios múltiplos: orientação sexual, gênero, etnia, pobreza, incapacidade física ou psíquica, etc. A diversidade significa entender cada indivíduo como único, reconhecendo as diferenças, aceitando e respeitando as divergentes opiniões além da simples tolerância (CARNEIRO, 2013; PATRICK e KUMAR, 2012). 
Na gestão sustentável de pessoas o processo de recrutamento e seleção deve estar bem alinhado com o que já foi exposto do triple bottom line, pensando em ações que visam contemplar suas diretrizes, a fim de alcançar pessoas capazes de agir e manter a organização pautada na sustentabilidade.

\subsubsection{TREINAMENTO E DESENVOLVIMENTO (T\&D)}

O Subsistema de Treinamento e Desenvolvimento (T\&D) é uma estratégia que a organização pode utilizar para reter talentos.

Ao ingressarem em uma organização os trabalhadores precisam entender suas funções, o processo organizacional, seu fluxo de trabalho, o que é esperado deles, em como realizar suas tarefas, e tudo isso parte de uma prática, de alguém passar o conhecimento daquilo que deve ser aprendido.

Desenvolver projetos e programas que contribuam para a sobrevivência das organizações e sua competitividade têm sido consequência de constantes alterações econômicas, políticas e sociais que vem influenciando o posicionamento mercadológico das empresas. Com esse cenário, espera-se uma postura crítica e reflexiva dos profissionais atuantes no desenvolvimento dos colaboradores (MENESES et al., 2010).

Muitos funcionários já apresentam no processo seletivo os conhecimentos, habilidades e atitudes (CHAs) que são requisitos para seus trabalhos. Alguns colaboradores utilizam o treinamento como uma maneira de se preparar para contribuir para as empresas, ou também, a fim de manter um bom desempenho às novas formas de trabalho. Os termos treinamento e desenvolvimento tendem a se combinar indicando os investimentos de curto e longo prazo que aumentam a base de habilidades que as empresas realizam a seus funcionários (BOHLANDER et al., 2005).

Para engajar e comunicar os funcionários diante de mudanças organizacionais, a área de T\&D da gestão de pessoas é a primeira a ser envolvida (JACKSON, RENWICK e JABBOUR, 2011). Jabbour, Santos e Nagano (2008) afirmam que o treinamento é um processo sistêmico de orientar o comportamento dos colaboradores para a realização de objetivos organizacionais.

Em uma organização que visa a gestão da qualidade, o treinamento deve conter 4 fases: (i) Levantamento das necessidades; (ii) Projeto e planejamento do treinamento; (iii) Execução; e (iv) Avaliação.

$\mathrm{Na}$ primeira fase espera-se que haja um levantamento das competências requeridas e as já desenvolvidas, para mapear e definir o que o treinamento deverá desenvolver. Após essa 
fase, deve-se estabelecer o programa a ser oferecido, e logo em seguida decidir qual será o local do treinamento, o tipo de material a ser utilizado, quais outros recursos serão necessários. Por último, deve-se avaliar a satisfação e a aprendizagem dos funcionários, para verificar se o que foi estabelecido no planejamento foi alcançado na execução (ISO, 2001).

As organizações sustentáveis devem pautar seus treinamentos e desenvolvimento em questões do triple bottom line, além de envolver parceiros que acreditam nas premissas sociais, ambientais e econômicas. Os gestores devem ser treinados com essas questões, assim como deve haver cursos internos e externos capazes de desenvolver competências nesses âmbitos (RENWICK, REDMAN e MAGUIRE, 2013; GREENWOOD, 2012; KRAMAR, 2014; EHNERT, 2009).

O Quadro 5 a seguir resume as ações que podem ser utilizadas no Treinamento e Desenvolvimento da Gestão Sustentável de Pessoas.

Quadro 5 - Subsistema de Gestão de Pessoas - Treinamento e Desenvolvimento

\begin{tabular}{|l|l|}
\hline SUBSISTEMA & \multicolumn{1}{c|}{ AÇÕES } \\
\hline \multirow{4}{*}{ T\&D } & Treinamento dos trabalhadores em questões sociais, ambientais e econômicas. \\
\cline { 2 - 3 } & Treinamento para criar envolvimento com o TBL. \\
\cline { 2 - 2 } & $\begin{array}{l}\text { Envolvimento com parceiros (sindicais e outras instituições) para treinamentos que incluem o } \\
\text { TBL. }\end{array}$ \\
\cline { 2 - 3 } & Disponibilizar cursos internos ou externos para o desenvolvimento das competências do TBL. \\
\cline { 2 - 3 } & Treinar a liderança para as questões do TBL. \\
\hline
\end{tabular}

Fonte: Adaptado de Renwick, Redman e Maguire (2013); Greenwood (2012); Kramar (2014); Ehnert (2009), Jabbour e Santos (2008).

Assim, as práticas de T\&D devem garantir de modo articulado o atendimento das metas de desenvolvimento das pessoas e das organizações. O Quadro 6 a seguir, elaborado por Meseses et al. (2010), traz algumas ações que são primordiais para que o T\&D seja considerado estratégico. 
Quadro 6 - Ações para que o sistema de T\&D torne-se estratégico

\begin{tabular}{|c|c|}
\hline SUBSISTEMA & AÇÕES NECESSÁRIAS \\
\hline \multirow{5}{*}{ Avaliação de Necessidades } & $\begin{array}{l}\text { Descrever necessidades em termos de ações desejadas } \\
\text { e não de conteúdos; }\end{array}$ \\
\hline & $\begin{array}{l}\text { Avaliar necessidades juntamente com perfil } \\
\text { demográfico, motivacional e profissional da clientela; }\end{array}$ \\
\hline & $\begin{array}{l}\text { Analisar o clima e suporte organizacionais ao uso de } \\
\text { novas capacidades de trabalho; }\end{array}$ \\
\hline & $\begin{array}{l}\text { Criar condições necessárias à transferência de } \\
\text { treinamento ou remediar a sua falta; }\end{array}$ \\
\hline & $\begin{array}{l}\text { Classificar as capacidades e hierarquiza-las para } \\
\text { elaboração de currículos de educação continuada. }\end{array}$ \\
\hline \multirow{7}{*}{ Planejamento de Ações de T\&D } & Utilizar taxonomias de resultados de aprendizagem; \\
\hline & $\begin{array}{l}\text { Escolher estratégias compatíveis com o grau de } \\
\text { complexidade do objetivo; }\end{array}$ \\
\hline & $\begin{array}{l}\text { Selecionar estratégias que aumentem a interação, a } \\
\text { busca independente de informações e a solução de } \\
\text { problemas reais; }\end{array}$ \\
\hline & $\begin{array}{l}\text { Elaborar avaliações de aprendizagem e exercícios } \\
\text { compatíveis com os objetivos; }\end{array}$ \\
\hline & $\begin{array}{l}\text { Criar situações em que o aprendiz terá que demonstrar } \\
\text { a competência a ser transferida para o trabalho } \\
\text { (simular a complexidade do ambiente real); }\end{array}$ \\
\hline & $\begin{array}{l}\text { Elaborar currículos para o desenvolvimento de } \\
\text { capacidades complexas (metacognitivas); }\end{array}$ \\
\hline & $\begin{array}{l}\text { Planejar o treinamento de modo a facilitar a } \\
\text { emergência dos efeitos do treinamento para os níveis } \\
\text { de grupo e organização. }\end{array}$ \\
\hline \multirow{4}{*}{ Avaliação de Efeitos de T\&D } & $\begin{array}{l}\text { Construir modelos integrados } \text { de reação, } \\
\text { aprendizagem, impacto, resultados e valor final de } \\
\text { avaliação de programas de T\&D; }\end{array}$ \\
\hline & $\begin{array}{l}\text { Construir modelos que incluam variáveis } \\
\text { demográficas, motivacionais e profissionais da } \\
\text { clientela e suas relações com as condições de trabalho; }\end{array}$ \\
\hline & $\begin{array}{l}\text { Realizar análises multivariadas a fim de identificar que } \\
\text { aspectos melhor explicar e predizem os resultados das } \\
\text { ações de T\&D; }\end{array}$ \\
\hline & $\begin{array}{l}\text { Mudar a atitude do profissional de T\&D; a } \\
\text { incompetência não é função apenas de características } \\
\text { individuais (saberes e motivações), mas de múltiplos } \\
\text { fatores ambientais externos, muitas vezes, } \\
\text { incontroláveis. }\end{array}$ \\
\hline
\end{tabular}

Fonte: Meneses et al. (2010, p. 23).

As práticas de Treinamento e Desenvolvimento contribuem para envolver os trabalhadores em habilidades e responsabilidades para solucionar questões, visando sempre a qualidade e a melhoria dos processos. Permitir que os colaboradores tenham conhecimento e consciência sobre as premissas do TBL é possibilitar que eles ajam de maneira mais sustentável. Além disso, há probabilidade de contribuírem para uma cultura organizacional mais proativa, sabendo lidar com as transformações que a humanidade vem enfrentando consideravelmente. 


\subsubsection{SISTEMAS DE PAGAMENTO E RECOMPENSA (SPR)}

Esse Subsistema também pode ser conhecido como Remuneração e Benefícios. Dutra (2004) afirma que essa subárea é responsável por valorizar o colaborador compensando o que ele vem entregando de resultados.

Além do salário, algumas outras formas de recompensar o funcionário são: participação nos lucros, bônus, participações acionárias, além de benefícios como plano de saúde, plano odontológico, vale-alimentação, que são maneiras de retenção de talentos.

Apesar disso, como as pessoas são únicas, e se motivam por diferentes fatores, a percepção das recompensas nas organizações podem influenciar seus julgamentos, não atendendo suas expectativas e necessidades, como de desenvolvimento pessoal e profissional, sua autorrealização, autoestima, entre outros fatores (JABBOUR e SANTOS, 2008).

As recompensas podem incentivar os funcionários a desenvolver habilidades, atitudes e conhecimentos que visam alcançar as metas organizacionais. Para contribuir para uma gestão ambiental eficiente, bem como para os outros dois âmbitos que sustentam o triple bottom line, as recompensas financeiras e não financeiras são fundamentais (JABBOUR, SANTOS e NAGANO, 2008).

Alguns críticos afirmam que para a sustentabilidade ocorrer, devemos mexer na parte econômica da empresa. Por isso, esse subsistema se torna tão importante, já que é através das recompensas e pagamentos que as pessoas se motivarão a modificar as ações organizacionais com base no triple bottom line.

Para uma organização sustentável, seriam interessante recompensas para sugestões advindas dos colaboradores para as questões do TBL nas ações organizacionais, desenvolver bônus gerenciais para bons resultados pautados no TBL, incluir metas que incluam o TBL na Participação dos Lucros e Resultados para alta gerência, estruturar parte da remuneração dos gestores baseada na boa gestão do tripé, entre outras atitudes (RENWICK, REDMAN e MAGUIRE, 2013; GREENWOOD, 2012; KRAMAR, 2014; EHNERT, 2009).

O Quadro 7 a seguir ilustra as ações que o subsistema de Sistema de Pagamento e Recompensa pode utilizar na Gestão Sustentável de Pessoas. 
Quadro 7- Subsistema de Gestão de Pessoas - Pagamento e Recompensa

\begin{tabular}{|c|c|}
\hline SUBSISTEMA & AÇÕES \\
\hline \multirow{8}{*}{ SPR } & Recompensas para sugestões dos trabalhadores no sistema de gestão pautado no TBL. \\
\hline & $\begin{array}{l}\text { Estruturar esquema de recompensa interligando as habilidades e ganhos na gestão do TBL e } \\
\text { as recompensas pagas. }\end{array}$ \\
\hline & Estruturar benefícios do TBL para os trabalhadores. \\
\hline & Estruturar incentivos fiscais com práticas do TBL \\
\hline & Desenvolver programas de bônus gerenciais para os bons resultados pautados no TBL. \\
\hline & $\begin{array}{l}\text { Incluir metas que envolvam o TBL nos programas de Participação nos Lucros e Resultados } \\
\text { para alta gerência }\end{array}$ \\
\hline & Estruturar parte da remuneração dos gestores baseada na boa gestão dos três pilares do TBL. \\
\hline & $\begin{array}{l}\text { Organizar recompensas baseadas nas premiações envolvidas na gestão do TBL, como } \\
\text { prêmios, certificados, reconhecimento público. }\end{array}$ \\
\hline
\end{tabular}

Fonte: Adaptado de Renwick, Redman e Maguire (2013); Greenwood (2012); Kramar (2014); Ehnert (2009).

Ou seja, esse subsistema pode servir de motivação ou punição aos comportamentos exibidos pelos colaboradores diante de uma gestão sustentável, sendo responsável por recompensá-los de maneira monetária ou não.

\subsubsection{GESTÃO DE DESEMPENHO E AVALIAÇÃO (GDA)}

Esse subsistema diz respeito à verificação do desempenho e do cumprimento das metas estabelecidas pela organização. O desempenho no trabalho possui duas vertentes de variação: os aspectos individuais e os contextuais, também chamados de sistêmicos. Logo, essa subárea deve buscar a diferenciação da contribuição dos indivíduos para a dinâmica do sistema, que normalmente segue os aspectos do ambiente empresarial (BORGES e MOURÃO, 2013).

O desempenho pode ser caracterizado como um conjunto de ações ou comportamentos que uma pessoa deve entregar para realizar os objetivos da organização. A avaliação de desempenho analisa a performance dos empregados, comparando as metas com os resultados entregues (DUTRA, 2004; JABBOUR, SANTOS E NAGANO, 2008).

A necessidade de mensuração de resultados muitas vezes passa por críticas quanto às distorções e a possível subjetividade que os instrumentos de avaliação podem conter. Com a globalização, as ferramentas de gestão de desempenho e avaliação devem integrar estratégias, aprendizagem, competências e indicadores qualitativos e quantitativos que sejam capazes de maximizarem os resultados esperados, o que muitas vezes não é encontrado (BRANDÃO et al., 2008).

Utilizar indicadores adequados para coletar informações possíveis de fazer comparações se torna um desafio para a área de gestão de pessoas. Borges e Mourão (2013, p. 
535) afirmam que existem algumas funções onde a mensuração e análise quantitativa do desempenho são mais fáceis de recolher, como da área financeira, comercial ou de produção; e outras funções como atendimento ao cliente, pós-venda, assessoria, em que os indicadores qualitativos são exigidos. Além disso, a subjetividade é difícil de ser desligada da avaliação de desempenho, pois sempre há necessidade de apreciação por parte de atores organizacionais, ou seja, as lideranças.

Jackson et al. (2011) trazem em seus estudos voltados mais à gestão verde, a importância dos indicadores mensurando o comportamento nessa área, com os resultados obtidos, além de compartilhar com todas as áreas da empresa se o projeto obtiver sucesso. Levando em consideração o TBL, podemos incluir nesses indicadores as questões econômicas e sociais também.

Schaltegger e Wagner (2006) afirmam que a gestão do desempenho em sustentabilidade requer um quadro de gestão que seja capaz de unir as áreas ambientais e sociais com a estratégia comercial e competitiva da organização, e por outro lado integrar as informações ambientais e sociais com as informações de negócios do âmbito econômico e com os relatórios de sustentabilidade.

Para uma gestão sustentável de pessoas algumas ações na área de GDA podem ser realizadas. Renwick et al. (2013) apresentaram em seus estudos algumas ações levando em consideração o aspecto ambiental. Como este trabalho é focado no tripé - ambiental, social e econômico, suas ações foram adaptadas. Deste modo, as ações delineadas foram:

Quadro 8 - Subsistema de Gestão de Pessoas - Desempenho e Avaliação

\begin{tabular}{|c|c|}
\hline SUBSISTEMA & AÇÕES \\
\hline \multirow{5}{*}{ GDA } & $\begin{array}{l}\text { Sistema de Gestão de Desempenho e Avaliação que inclua indicadores sociais, ambientais e } \\
\text { econômicos de desempenho. }\end{array}$ \\
\hline & Comunicação e diálogo com toda a organização sobre o sistema GDA e a gestão do TBL. \\
\hline & $\begin{array}{l}\text { Definição de metas e responsabilidade para com os } 3 \text { âmbitos do TBL aplicáveis em todos os } \\
\text { níveis da organização. }\end{array}$ \\
\hline & Avaliações para liderança com metas a serem alcançadas e resultados pautados no TBL. \\
\hline & Sistemas de não benefícios para o não cumprimento das metas e responsabilidades na gestão. \\
\hline
\end{tabular}

Fonte: Adaptado de Renwick, Redman e Maguire (2013).

Essa área tem um papel importante na gestão sustentável de pessoas, pois ao planejar e inserir o tripé na estratégia da organização, a comunicação para todos os níveis organizacionais integrará as áreas e agregará valor aos aprendizados que contemplam os aspectos sociais, econômicos e ambientais (CHENG et al., 2010). 
Como toda organização vive de resultados e é feita de seus colaboradores, buscar resultados através das competências deles, mensurando seus comportamentos, irá permitir o alinhamento entre os objetivos organizacionais e o sucesso de uma gestão sustentável pautada no triple bottom line.

\subsubsection{SAÚdE, SEGURANÇA E QUALIDADE DE VIDA NO TRABALHO (SSQVT)}

Muitos estudos tem trazido argumentos de que há uma interligação entre os resultados ambientais e sociais com a sustentabilidade organizacional. Para que sejam desenvolvidas e implementadas políticas e capacidades ambientais avançadas, as políticas de gestão de pessoas devem estar alinhadas, criando confiança entre os stakeholders (KRAMAR, 2014).

Os subsistemas de gestão de pessoas devem estar todos inter-relacionados. Então, para atrair e reter talentos em uma organização é muito importante que ela invista na qualidade do local de trabalho (EHNERT, 2009).

Nos últimos anos, a importância da saúde individual tem crescido com a consciência de que deve haver prevenção e promoção de um estilo de vida mais voltado ao bem-estar e a qualidade de vida, balanceando a vida profissional e pessoal (EHNERT, 2009).

Buscar identificar quais os fatores que aumentam a expectativa de vida, reduzem a mortalidade, as doenças ocupacionais, contribuindo para o bem-estar e a qualidade de vida tem sido ansiado por diversos agentes: governos, órgãos internacionais, pesquisadores (BORGES e MOURÃO, 2013).

As práticas de gestão de pessoas devem ter flexibilidade para construir capacidades de forças de trabalho, que respeitem a gestão da diversidade, os níveis de saúde e segurança no local do trabalho, que vão refletir em preocupações éticas. Além disso, o desempenho da organização deve ser medido com indicadores que agreguem o bem-estar do colaborador, da comunidade ao entorno e da qualidade de vida (KRAMAR, 2014).

A qualidade de vida no trabalho possui diversas vertentes, definições, que podem ser desde o enfoque mais clínico, onde não há doenças pessoais, até as exigências de recursos, estratégias, e procedimentos realizados pelas organizações que afetem a satisfação dos colaboradores. Quando estes não estão se sentindo realizados dentro da organização, pode desencadear mudanças na maneira como eles levam a vida, e por consequência isto pode afetar a produtividade na execução das tarefas organizacionais (LIMONGI-FRANÇA e ARELLANO, 2002; LEITE et al., 2014).

Também, Vergara e Branco (2001) alegam que uma empresa que quer ser socialmente responsável deve ser sinônima de uma organização "humanizada", não preocupada apenas 
com os lucros e acionistas, mas também com seus funcionários, desenvolvendo ações no âmbito interno.

Os trabalhadores mudaram suas percepções a respeito da atividade laboral. O novo enfoque considera as organizações não apenas aquelas que geram problemas, mas sim que promovem saúde. A organização e seus funcionários passam a ter uma relação central, não só os recrutando e retendo, como dando ferramentas para que se sintam satisfeitos, sejam produtivos, estejam comprometidos e desenvolvam suas capacidades e a criatividade (LARSON e LUTHANS, 2006; NADER et al, 2014).

Gabriunas (2010) afirmou que embora existam estudos diversos referentes aos fatores organizacionais, não existem trabalhos que relacionem diretamente o desempenho social corporativo e a satisfação laboral. Além disso, o envolvimento da organização com as ações de responsabilidade social criam expectativas positivas nos trabalhadores, ao deixarem visível a sensibilidade frente às questões sociais.

A dimensão interna afeta os trabalhadores nos aspectos de saúde e segurança, gestão de pessoas e adaptação às mudanças, ao mesmo tempo em que a externa abrange o meio a qual a organização está inserida e as suas respostas à comunidade onde atua. Como a satisfação dos funcionários está nos âmbitos cognitivos e afetivos, os mesmos criam conceitos e sentimentos sobre a empresa a partir do que experimentam, sentem e veem (CÁMARAS, 2006; GABRIUNAS, 2010).

Walton (1973) propôs um modelo de 8 categorias com critérios e indicadores de qualidade de vida no trabalho que afetam o trabalhador no seu trabalho.

Quadro 9 - Modelo de Walton de Qualidade de Vida no Trabalho

\begin{tabular}{|l|l|}
\hline CRITÉRIOS & INDICADORES DE QVT \\
\hline 1. Compensação justa e adequada & $\begin{array}{l}\text { Equidade interna e externa; justiça na compensação; } \\
\text { partilha de ganhos de produtividade. }\end{array}$ \\
\hline 2. Condições de trabalho & $\begin{array}{l}\text { Jornada de trabalho razoável; ambiente físico seguro e } \\
\text { saudável; ausência de insalubridade. }\end{array}$ \\
\hline 3. Uso e desenvolvimento de capacidades & $\begin{array}{l}\text { Autonomia; significado da tarefa; identidade da tarefa; } \\
\text { variedade de habilidade. }\end{array}$ \\
\hline 4. Oportunidade de crescimento e segurança & $\begin{array}{l}\text { Possibilidade de carreira; crescimento pessoal; } \\
\text { perspectiva de avanço salarial; segurança de emprego. }\end{array}$ \\
\hline 5. Integração social na organização & $\begin{array}{l}\text { Ausência de preconceitos; igualdade; mobilidade; } \\
\text { relacionamento; senso comunitário. }\end{array}$ \\
\hline 6. Constitucionalismo & $\begin{array}{l}\text { Respeito às leis trabalhistas; privacidade pessoal; } \\
\text { liberdade de expressão; tratamento imparcial. }\end{array}$ \\
\hline 7. Trabalho e espaço total da vida & $\begin{array}{l}\text { Tempo para lazer com a família; papel balanceado no } \\
\text { trabalho; estabilidade de horários; poucas mudanças } \\
\text { geográficas. }\end{array}$ \\
\hline 8. Relevância social da vida no trabalho & $\begin{array}{l}\text { Imagem da empresa; responsabilidade social da } \\
\text { empresa; responsabilidade pelos produtos; práticas de } \\
\text { emprego. }\end{array}$ \\
\hline
\end{tabular}

Fonte: Walton (1973). 
Vasconcelos (2001) traz que o primeiro critério busca a obtenção da remuneração adequada ao trabalho que é realizado, respeitando a equidade interna e externa, ou seja, entre os funcionários e o mercado de trabalho em geral. O segundo critério, envolve a jornada e carga de trabalho, além dos materiais disponíveis para a realização do trabalho. O critério do Uso e desenvolvimento de capacidades abrange o aproveitamento do capital intelectual humano, além do empowerment que permite que o colaborador utilize sua criatividade para resolução de problemas. O quarto critério, Oportunidade de Crescimento e segurança, implica em ações implementadas pelas organizações que mensuram o quanto essas práticas estão sintonizadas ao respeito e valorização do colaborador.

O quinto critério, Integração Social na Organização, é relativa a questão do respeito à diversidade, onde há o cultivo do bom relacionamento. O critério de Constitucionalismo, mensura os direitos trabalhistas que são cumpridos pelas organizações. No sétimo critério, Trabalho e espaço total da vida, abrange o equilíbrio entre a vida profissional e pessoal, e o último critério, Relevância do trabalho na vida, refere-se à percepção do colaborador frente à imagem organizacional, aos produtos e serviços oferecidos pela empresa, entre outros (VASCONCELOS, 2001).

Diante do exposto, e baseado no modelo de Walton (1973), as seguintes ações foram delineadas para a Gestão Sustentável de Pessoas utilizar como base.

Quadro 10 - Subsistema de Gestão de Pessoas - Saúde, Segurança, Qualidade de Vida no Trabalho

\begin{tabular}{|c|c|}
\hline SUBSISTEMA & AÇÕES \\
\hline \multirow{5}{*}{ SSQVT } & Garantir uma jornada de trabalho razoável, onde as horas extras sejam raras ou inexistentes. \\
\hline & $\begin{array}{l}\text { Garantir um ambiente de trabalho que promova bons relacionamentos, principalmente frente à } \\
\text { diversidade, com ausência de preconceitos. }\end{array}$ \\
\hline & Proporcionar materiais e ambiente que garantam a saúde e segurança do trabalhador. \\
\hline & Respeitar as leis trabalhistas e de direitos humanos. \\
\hline & $\begin{array}{l}\text { Traçar e implantar políticas que eliminem qualquer forma de abuso de poder, autoritarismo, } \\
\text { humilhações, evitando assédio moral na organização e garantindo a integridade da segurança } \\
\text { do colaborador. }\end{array}$ \\
\hline
\end{tabular}

Fonte: Adaptado de Walton (1973).

Por fim, sabe-se que as organizações devem propiciar as condições básicas para os colaboradores permanecerem com saúde, segurança e que consigam equilibrar sua vida profissional e pessoal. Para isso, em uma gestão sustentável de pessoas, o foco deve ser evitar o risco de acidentes, tratando os colaboradores com os princípios do respeito, transparência e honestidade, respeitando a privacidade, bem como a liberdade e autonomia dentro dos valores organizacionais, assim como outras ações podem ser tomadas. 


\subsection{OUTROS TÓPICOS DA GESTÃO DE PESSOAS}

A Gestão de Pessoas evolui conforme as necessidades e as mudanças em nível mundial. Atualmente, as empresas se preocupam mais em relatar as práticas sociais externas, e menos as práticas internas, relacionadas aos funcionários. Contudo, Molica et al. (2008) afirmam que essa relação entre trabalhador e empresa é tratada sob a ótica da Responsabilidade Social Corporativa, também tratado como Sustentabilidade Organizacional neste trabalho, já que além do Instituto Ethos utilizar esse tema em seus indicadores, outros organismos multilaterais também o empregam, como a Global Reporting Initiative, a Organização Internacional de Trabalho (OIT) e a Agenda Global Compact da Organização das Nações Unidas (ONU).

A fim de comunicar os stakeholders sobre suas práticas, cada vez mais as organizações adotam relatórios de sustentabilidade, visando divulgar suas ações com transparência às partes interessadas, possibilitando maiores interações entre ambos (DAUB, 2007; GOLOB e BARTLETT, 2007).

De acordo com Rosenfield e Pauli (2012), em 1948 houve a inauguração de um código de ética universal para reafirmar a dignidade humana: a Declaração Universal dos Direitos Humanos. Ela veio logo após o cenário de grande extermínio caracterizado pelos nazistas na $2^{\mathrm{a}}$ Guerra Mundial, no qual eles romperam a naturalidade em que os direitos humanos estavam inseridos.

Deste modo, esse Pós-Guerra fica marcado como uma tentativa de reconstrução desses direitos e, com algumas iniciativas lançadas ao longo dos anos a fim de definir as melhores condições de trabalho digno e decente.

Além das diretrizes do Global Reporting Initiative trazer elementos sobre práticas trabalhistas e trabalho decente, outras iniciativas como a United Nations Global Compact e a Agenda de Trabalho Decente da Organização Internacional do Trabalho, trouxeram também essas questões, que auxiliam nas discussões sobre as práticas éticas, no respeito aos Direitos Humanos, eliminação de trabalhos forçados, entre outros aspectos.

Como este trabalho se pautou em analisar os relatórios anuais ou de sustentabilidade das organizações, a fim de coletar informações sobre as práticas trabalhistas envolvendo a área de gestão de pessoas, os tópicos a seguir fundamentam essas iniciativas globais que delinearam diretrizes para as organizações utilizarem como base, visando caracterizar as melhores práticas que as empresas devem exercer diante dos seus funcionários. 


\subsubsection{GLOBAL REPORTING INITIATIVE}

A elaboração de relatórios de sustentabilidade que mensuram e divulgam os impactos socioambientais ocasionados pelas atividades organizacionais tem sido uma prática comum em diversos países por inúmeras empresas (CAMPOS et al., 2013).

Daub (2007) trouxe que historicamente existem 3 diferentes tipos de relatórios de sustentabilidade como no Quadro 11 a seguir:

Quadro 11 - Tipos de relatórios de sustentabilidade

\begin{tabular}{|l|l|l|}
\hline Relatórios & Período & Informações \\
\hline Sociais & Década de 1970 & $\begin{array}{l}\text { Demanda por balanços referentes } \\
\text { aos aspectos sociais }\end{array}$ \\
\hline Ambientais & Fim dos anos 1980 questões ambientais, \\
\hline Anuais & Metade da década de 1990 & $\begin{array}{l}\text { Voltado à quegurança e saúde } \\
\text { segúcia e }\end{array}$ \\
\hline
\end{tabular}

Fonte: Elaborado a partir de Daub (2007).

A evolução das tendências do mercado contribuíram para as adaptações do formato e conteúdo desses relatórios, no qual muitas empresas passaram a utilizar o padrão da Global Reporting Initiative (GRI). Localizada hoje em Amsterdã, na Holanda, é uma organização sem fins lucrativos, criada em 1997, e formada por uma rede internacional de associações civis, empresas e outras organizações (NOGUEIRA e FARIA, 2012; CAMPOS et al., 2013).

O GRI é atualmente o modelo mais utilizado pelas empresas, a nível mundial, como uma referência no desenvolvimento de relatórios sustentáveis, mesmo porque o objetivo de suas diretrizes é criar uma harmonia nos inúmeros sistemas de informações utilizados (DAUB, 2007; BROWN et al., 2009).

A evolução da trajetória do GRI pode ser acompanhada na Figura 3 a seguir: 


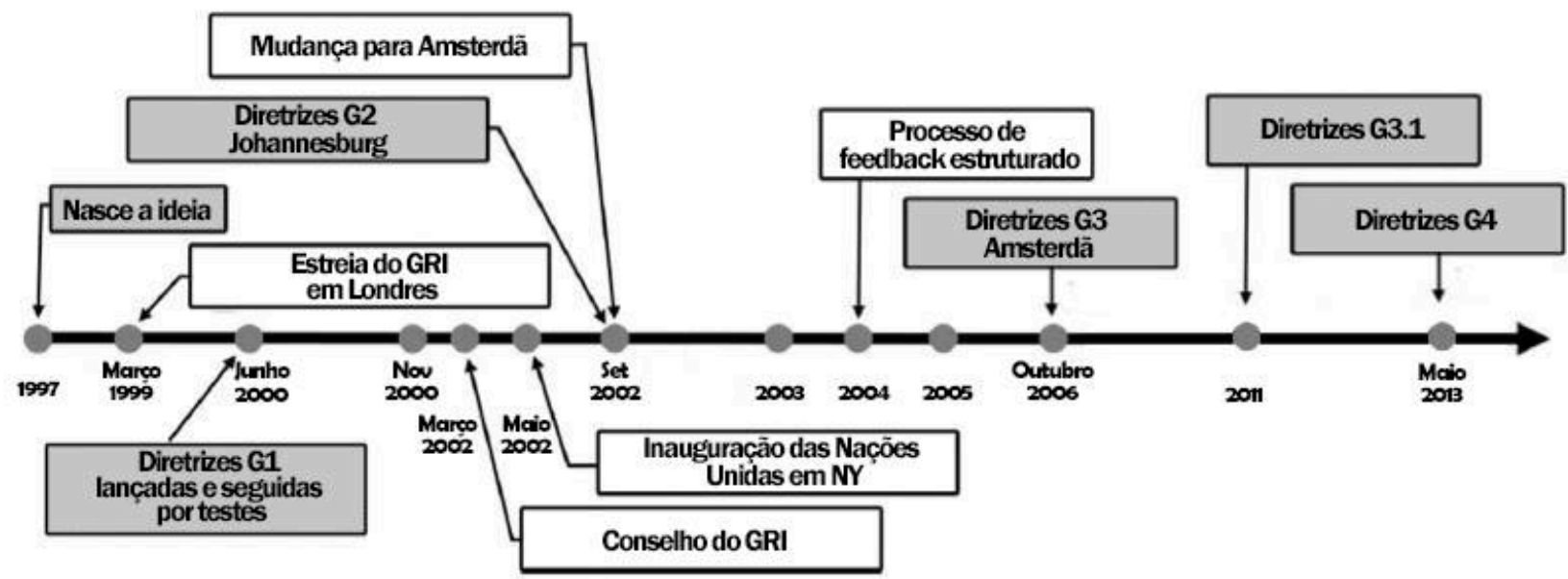

Fonte: Adaptado de Brown, Martin e Lessidrenska (2009).

Além disso, Campos et al. (2013) relatam que esse tipo de relatório, que abrange o triple bottom line, com as abordagens social, ambiental e econômica, tem o intuito de se tornarem tão rotineiros, como são os relatórios financeiros, que podem auxiliar na comunicação das informações das empresas.

Dentro do item Conteúdos padrão, há o conteúdo padrão específico que está dividido nas categorias Econômica, Ambiental e Social, este último, o foco deste trabalho. As subcategorias do Social estão distribuídas da seguinte maneira: Práticas trabalhistas e trabalho decente; Direitos Humanos; Sociedade e Responsabilidade pelo produto (GRI, 2013).

Essas diretrizes foram planejadas e desenvolvidas a partir de acordos e indicadores internacionais, com objetivo de que possam ser acessadas e comparadas, facilitando as informações. Para os stakeholders tomarem as melhores decisões, a transparência no quesito sustentabilidade é um fator importante, pois impacta na credibilidade da empresa (BEBBINGTON et al., 2008; GRI, 2013).

As críticas quanto a não padronização do reporte do GRI podem ser encontradas nos estudos de Brown et al. (2009) e Campos et al. (2013). Eles trazem que o relatório não detalha as informações de maneira suficiente; não retrata uma imagem sobre os impactos das empresas dentro dos valores sociais. Há também a conotação de que por ter poucos leitores são criados apenas para serem armazenados; não há padrões impostos, levando à diferenças significativas; e a falta de parâmetros desde a maneira como o relatório se apresenta até as demonstrações do conteúdo, retratam a dificuldade do leitor de acessar às informações. Ou 
seja, as organizações precisam lidar com melhorias a fim de alcançarem êxito total nas publicações.

Além da melhoria do reporte, Molica et al. (2008) explana que no contexto de transformações que as corporações estão passando, a lógica liberal tem sido predominante, favorecendo a flexibilização de direitos trabalhistas. Apesar da existência de conflitos de interesses ser algo inerente nas relações trabalhistas, os mesmos autores trazem que se houver negociações baseadas nas premissas da Sustentabilidade Corporativa, esta seria uma boa oportunidade para os sindicatos dos empregadores e trabalhadores inserirem temas que melhorariam o ambiente de trabalho significativamente.

\subsubsection{UNITED NATIONS GLOBAL COMPACT}

Uma importante contribuição internacional no avanço da discussão sobre a postura ética nos negócios ocorreu com a agenda do chamado Global Compact (GC), proposto por Kofi Annan no ano 1999, quando então secretário geral da Organização das Nações Unidas (ONU) (CORTINA, 2002).

Os princípios do Pacto Global foram baseados em 4 eixos focados na Responsabilidade Social Corporativa: Direitos Humanos, Trabalho, Meio Ambiente e Combate à corrupção. A intenção é que as empresas, dentro de sua capacidade de influência, aceitem, apoiem e apliquem um conjunto de valores, denominados 10 princípios, discriminados a seguir (UNGLOBALCOMPACT, 2014):

Quadro 12 - Os 10 Princípios do Pacto Global das Nações Unidas

\begin{tabular}{|l|}
\hline \multicolumn{1}{|c|}{ Direitos Humanos } \\
\hline 1. As empresas devem apoiar e respeitar a proteção dos direitos humanos reconhecidos internacionalmente. \\
\hline 2. Certificar-se de que não são cúmplices em abusos dos direitos humanos. \\
\hline \multicolumn{1}{c|}{ Trabalho } \\
\hline $\begin{array}{l}\text { 3. As empresas devem defender a liberdade de associação e reconhecimento efetivo do direito à negociação } \\
\text { coletiva. }\end{array}$ \\
\hline 4. A eliminação de todas as formas de trabalho forçado ou compulsório. \\
\hline 5. A erradicação efetiva do trabalho infantil. \\
\hline 6. A eliminação da discriminação no emprego e ocupação. \\
\hline \multicolumn{1}{|c|}{ Meio Ambiente } \\
\hline 7. As empresas devem apoiar uma abordagem preventiva sobre os desafios ambientais. \\
\hline 8. Desenvolver iniciativas a fim de promover maior responsabilidade ambiental. \\
\hline 9. Incentivar o desenvolvimento e a difusão de tecnologias ambientalmente sustentáveis. \\
\hline \multicolumn{1}{c|}{ Combate à corrupção. } \\
\hline 10. As empresas devem combater a corrupção em todas as suas formas, inclusive extorsão e propina. \\
\hline
\end{tabular}

Fonte: United Nations Global Compact (2014).

O pré-requisito exigido para se fazer parte do GC é uma carta declarando comprometimento com esses princípios. A gerência dele se dá por alguns funcionários, o 
reporte depende do autorrelato das corporações, e o monitoramento dessas atividades é realizada por atores da sociedade civil (LIM e TSUTSUI, 2011).

Pena et al. (2005) apresentaram algumas restrições ao programa no que tange a estratégia efetiva no avanço do controle social das organizações privadas. Num primeiro momento pode-se pensar que o caráter voluntário resulta em dificuldades, caso houvesse a necessidade de punição àqueles que descumprissem esses princípios. Outro aspecto que ocorre é bem próximo às críticas ao GRI, que por não obedecer um padrão, a falta de definição resulta em dificuldades no alcance e entendimento desses conceitos.

Sethi e Schepers (2014) em uma análise de 10 anos de informações fornecidas pelo GC e por outros meios de comunicação os levaram a conclusão de que a entidade não empenhou esforços para sustentar sua missão que era incorporar os princípios às corporações. Eles levantaram que a GC se preocupou apenas em demonstrar ao longo dos anos o número de signatários alcançados, mas que não forneciam informações significativas sobre quanto e como as empresas tem melhorado suas condutas.

\subsubsection{AGENDA DE TRABALHO DECENTE}

Dentro do trabalho decente, a agenda da Organização Internacional de Trabalho (OIT) é bem recorrente. Alinhada com as diretrizes da ONU, procurou dimensionar os problemas mais graves enfrentados pelos trabalhadores, ressaltando a importância da adoção de agendas políticas capazes de promoverem o trabalho decente e o combate à discriminação (PRONI, 2013).

De acordo com a OIT (2014), o trabalho decente é definido como:

Ponto de convergência dos quatro objetivos estratégicos da OIT: o respeito aos direitos no trabalho (em especial aqueles definidos como fundamentais pela Declaração Relativa aos Direitos e Princípios Fundamentais no Trabalho e seu seguimento adotada em 1998: (i) liberdade sindical e reconhecimento efetivo do direito de negociação coletiva; (ii) eliminação de todas as formas de trabalho forçado; (iii) abolição efetiva do trabalho infantil; (iv) eliminação de todas as formas de discriminação em matéria de emprego e ocupação, a promoção do emprego produtivo e de qualidade, a extensão da proteção social e o fortalecimento do diálogo social.

Assim, a OIT lançou uma agenda, onde as Políticas Gerais para a realização dos objetivos centrais da estratégia de gerar trabalho decente estão especificadas a seguir, em políticas, objetivos e metas. 
Quadro 13 - Agenda de políticas gerais para a promoção do trabalho decente pela OIT

\begin{tabular}{|c|c|c|}
\hline Políticas & Objetivos & Metas \\
\hline $\begin{array}{l}\text { 1. Crescimento } \\
\text { econômico } \\
\text { promotor do } \\
\text { emprego. }\end{array}$ & $\begin{array}{l}\text { A geração de mais } \\
\text { oportunidades de emprego } \\
\text { deve ser considerada } \\
\text { objetivo central da política } \\
\text { econômica. }\end{array}$ & $\begin{array}{l}\text { Assegurar um crescimento econômico de, pelo menos, } 5 \% \\
\text { ao ano nos próximos } 10 \text { anos, de maneira sustentada e não } \\
\text { flutuante, como condição necessária para reduzir } \\
\text { significativamente o atual déficit de trabalho decente. }\end{array}$ \\
\hline $\begin{array}{l}\text { 2. Respeito efetivo } \\
\text { aos princípios e } \\
\text { direitos } \\
\text { fundamentais no } \\
\text { trabalho. }\end{array}$ & $\begin{array}{l}\text { Assegurar o respeito efetivo } \\
\text { aos princípios e direitos } \\
\text { fundamentais no trabalho. }\end{array}$ & $\begin{array}{l}\text { Os direitos fundamentais no trabalho constituem um corpo } \\
\text { mínimo e universalmente aceito de direitos do trabalho } \\
\text { incorporados às respectivas legislações nacionais e à } \\
\text { cultura do trabalho dos diferentes países da região. }\end{array}$ \\
\hline $\begin{array}{l}\text { a) Trabalho } \\
\text { infantil. }\end{array}$ & $\begin{array}{l}\text { Eliminação progressiva do } \\
\text { trabalho infantil. }\end{array}$ & $\begin{array}{l}\text { 1. Eliminar as piores formas de trabalho infantil num } \\
\text { prazo de } 10 \text { anos (2015). } 2 \text {. Eliminar o trabalho infantil } \\
\text { em sua totalidade em um prazo de } 15 \text { anos }(2020) \text {. }\end{array}$ \\
\hline $\begin{array}{l}\text { b) Trabalho } \\
\text { forçado. }\end{array}$ & $\begin{array}{l}\text { Eliminação progressiva do } \\
\text { trabalho forçado. }\end{array}$ & $\begin{array}{l}\text { Em um prazo de } 10 \text { anos, reduzir entre } 20 \% \text { e } 35 \% \text { o } \\
\text { número de trabalhadores em regime de trabalho forçado. }\end{array}$ \\
\hline $\begin{array}{l}\text { c) Liberdade } \\
\text { sindical e } \\
\text { negociação } \\
\text { coletiva. }\end{array}$ & $\begin{array}{l}\text { Melhorar o cumprimento } \\
\text { dos direitos fundamentais } \\
\text { por meio de avanços na } \\
\text { garantia dos diferentes } \\
\text { elementos da liberdade } \\
\text { sindical, em particular a não } \\
\text { discriminação sindical, } \\
\text { otimizando a cobertura da } \\
\text { negociação coletiva e } \\
\text { ampliando seus conteúdos. }\end{array}$ & $\begin{array}{l}\text { Dotar as legislações de melhores elementos de proteção } \\
\text { sindical, em especial de procedimentos e recursos } \\
\text { administrativos e judiciais efetivos e rápidos para o caso } \\
\text { de violações desses direitos, melhorando também a } \\
\text { qualidade dos acordos e convênios, tanto com relação ao } \\
\text { número de trabalhadores cobertos (com um aumento de } \\
10 \% \text {, ao menos, em nível nacional) como à ampliação de } \\
\text { seus conteúdos (por exemplo, incluindo cláusulas sobre } \\
\text { produtividade) e à solução autônoma de conflitos. }\end{array}$ \\
\hline $\begin{array}{l}\text { d) Não } \\
\text { discriminação e } \\
\text { igualdade no } \\
\text { trabalho. }\end{array}$ & $\begin{array}{l}\text { Eliminar progressivamente } \\
\text { os mecanismos de } \\
\text { discriminação existentes no } \\
\text { mercado de trabalho. }\end{array}$ & $\begin{array}{l}\text { Reduzir em } 50 \% \text { os índices de segregação e as } \\
\text { desigualdades de rendimento por gênero e origem étnico- } \\
\text { racial (com relação aos níveis atuais) em um prazo de } 10 \\
\text { anos. }\end{array}$ \\
\hline $\begin{array}{l}\text { 3. Maior eficiência } \\
\text { e abrangência da } \\
\text { proteção social. }\end{array}$ & $\begin{array}{l}\text { Ampliar e fortalecer os } \\
\text { diferentes sistemas de } \\
\text { proteção social dos } \\
\text { trabalhadores. }\end{array}$ & $\begin{array}{l}\text { Em um prazo de } 10 \text { anos, incrementar em } 20 \% \text { a cobertura } \\
\text { da proteção social. }\end{array}$ \\
\hline $\begin{array}{l}\text { 4. Diálogo social } \\
\text { efetivo. }\end{array}$ & $\begin{array}{l}\text { Promover a } \\
\text { institucionalização do } \\
\text { diálogo social em bases } \\
\text { voluntárias. }\end{array}$ & $\begin{array}{l}\text { Estimular que todos os países da região realizem ações } \\
\text { para fortalecer o diálogo social e que em um prazo } \\
\text { máximo de } 10 \text { anos contem com espaços de diálogo social } \\
\text { institucionalizados, sustentáveis em bases voluntárias. }\end{array}$ \\
\hline
\end{tabular}

Fonte: OIT (2008).

Logo, precisa existir uma atenção maior nas condutas empresariais, pois Sethi e Schepers (2014) observaram que nos últimos anos houve flagrantes envolvendo questões como abusos de direitos humanos, trabalho infantil, práticas trabalhistas injustas, suborno e corrupção, degradação ambiental.

Todas essas diretrizes visam atender as corporações em nível mundial. As mudanças não ocorrem rapidamente, mas a identificação de causas que inflijam as condições de trabalho 
dos colaboradores, já é um passo para que ações e medidas sejam tomadas para melhorias serem implantadas.

O setor bancário não está distante dessa realidade, e muitas mudanças ocorreram na sua força de trabalho. Como objeto de estudo deste trabalho, o próximo item discorre sobre a contextualização do setor e suas mudanças ocorridas durante os últimos anos.

\subsection{SETOR BANCÁRIO DE VAREJO}

\subsubsection{CARACTERÍSTICAS}

A partir da evolução do comércio e da criação dos instrumentos de créditos pode-se observar o importante papel desempenhado pelos bancos na sociedade, pois foi por meio destas instituições que as moedas foram e são criadas. De acordo com Mankiw (2005) a criação da moeda se dá a partir dos empréstimos de uma parte de todos os depósitos captados, tornando assim a economia mais líquida, uma vez que há mais meios de troca no mercado corrente.

Assaf Neto (2014) ressalta que essa capacidade de criação de moedas é a principal característica que diferencia os bancos das demais instituições financeiras. Além disso e da prestação de serviços, as instituições financeiras e suas crises "afetam o crédito e os juros, os investimentos e o nível da atividade econômica" (CORAZZA, 2001, p. 02).

O setor bancário brasileiro passou por diversas mudanças significativas e tem sido foco de extensos estudos, especialmente após o Plano Real. Antes dele, o setor passou por um processo de expressiva expansão, graças a sua alta rentabilidade com os ganhos de floating ${ }^{1}$ devido aos índices inflacionários da época (CORAZZA, 2001).

Após o controle da inflação os bancos precisaram se reestruturar, já que perderam sua principal fonte de renda. Corazza (2001) afirma que essas receitas representavam $87,3 \%$ das receitas bancárias e foi reduzida para $2 \%$ em 1994, chegando a representar apenas $0,1 \% \mathrm{em}$ 1995.

Como alternativa para recuperar suas receitas o sistema embarcou numa onda de crédito fácil, contudo, os bancos não dispunham de bons mecanismos de análise de crédito, resultando no aumento generalizado da inadimplência (CYSNE e COSTA, 1996).

A partir deste contexto, as instituições bancárias viram na cobrança de tarifas de serviços, autorizadas desde 1967 mas não utilizadas, a oportunidade de recuperar a alta

\footnotetext{
${ }^{1}$ Cysne e Costa (1996) definem os ganhos de floating como o ganho de capital gerado a partir da desvalorização de um passivo pelo aumento sistemático dos preços - a inflação.
} 
rentabilidade. Essas receitas foram ganhando cada vez mais importância e representatividade nos resultados financeiros destas instituições, que em 2010 cobriam todas as despesas de pessoal e parte das administrativas (METZNER e MATIAS, 2015).

Graças à importância das receitas da prestação de serviços, os estudos sobre a satisfação dos clientes em relação a este aspecto foram ganhando cada vez mais importância. Um dos principais achados nestes estudos foi a relação do cliente com o gerente do banco destacando a importância dos recursos humanos no desempenho financeiro das instituições bancárias (MELLO et al., 2006; MADILL et al., 2002; MOUTINHO e SMITH, 2000; KRISHNAN et al., 1999).

As instituições bancárias podem ser classificadas de acordo com suas funções específicas, tamanho e atuação, sendo as principais classificações: bancos comerciais, bancos múltiplos e caixas econômicas, sendo a primeira classificação o foco deste trabalho.

Os bancos comerciais são constituídos, necessariamente, sob a forma de sociedade por ações, e executa principalmente operações de crédito de curto prazo. A principal característica deste segmento é a criação de moeda através de poupança e empréstimos, e tem como uma das principais atividades a prestação de serviços (ASSAF NETO, 2014).

A partir do volume de negócios os bancos comerciais podem ser classificados como bancos de varejo ou bancos de negócios. Os bancos de varejo costumam atuar em diversas modalidades e produtos financeiros com a mesma denominação social e abrange um grande número de clientes. Ao contrário dos bancos de negócios, que atuam prioritariamente em operações de crédito de maior complexidade, assim trabalham com um número reduzido de clientes (ASSAF NETO, 2014).

Os bancos múltiplos surgiram da evolução dos bancos comerciais aliado ao crescimento do setor e da tendência de formação dos conglomerados bancários. A principal característica desta instituição é a atuação em carteiras de quatro tipos: banco comercial, banco de investimento e desenvolvimento, sociedade de crédito, financiamento e investimento e sociedade de crédito imobiliário. Para um banco ser classificado como múltiplo ele deve atuar ao menos em duas destas atividades, sendo necessariamente uma delas banco comercial ou de investimento (ASSAF NETO, 2014).

Por fim as Caixas Econômicas são instituições públicas de atuação autônoma, são classificadas como órgãos auxiliares do Governo Federal e possuem objetivo social. Apesar de atuar como banco múltiplo e comercial sua principal função é atuar no Sistema Financeiro de Habitação (ASSAF NETO, 2014). 
Neste trabalho, as instituições analisadas pertencem à classificação de bancos de varejo e da caixa econômica. O próximo tópico trata um pouco dos números do setor, como os ativos e lucro dos bancos analisados neste trabalho e algumas estatísticas do Censo da Diversidade do setor.

\subsubsection{ESTATÍSTICAS}

Dados do Banco Central do Brasil (BACEN, 2015) mostram que em dezembro de 2014 os cinco maiores bancos classificados pelo ativo total e lucro eram: o Banco do Brasil (BB), Itaú Unibanco, Caixa Econômica Federal (CEF), Bradesco e Santander. Os respectivos ativos e lucros por banco são mostrados na Tabela 1 a seguir.

Tabela 1 - Classificação dos 5 maiores bancos brasileiros

\begin{tabular}{lrrr}
\hline \multicolumn{1}{c}{ Instituições } & Ativo Total & Lucro Líquido & $\mathbf{N}^{\mathbf{0}}$ de Agências \\
\hline BANCO DO BRASIL & 1.324 .464 .414 & 5.833 .139 & 5.524 \\
ITAÚ UNIBANCO & 1.117 .848 .197 & 10.311 .204 & 3.885 \\
CAIXA ECONÔMICA FEDERAL & 1.064 .674 .796 & 3.702 .318 & 3.391 \\
BRADESCO & 883.438 .773 & 7.880 .304 & 4.665 \\
SANTANDER & 598.224 .807 & 1.218 .969 & 2.640 \\
\hline
\end{tabular}

No que diz respeito aos recursos humanos o Censo da Diversidade realizado pela Federação Brasileira de Bancos (Febraban) em 2014 mostra que não existe predominância de sexo na atividade bancária, visto que $51,7 \%$ dos funcionários são do sexo masculino e 48,3\% são do sexo feminino. Apesar do equilíbrio entre os sexos na ocupação de vagas o rendimento feminino ainda é inferior ao masculino representando $77,9 \%$ dos rendimentos de funcionários do sexo masculino.

O Censo da Diversidade mostra ainda que a rotatividade de funcionários é baixa já que $62,1 \%$ dos entrevistados estão no mesmo emprego há mais de 5 anos. No Brasil, a média de permanência em um emprego é de 18 meses, de acordo com a Relação Anual de Informações Sociais (RAIS), trazida pelo estudo da Febraban.

Como reflexo dessa baixa rotatividade tem-se uma população mais velha trabalhando nestes cargos, já que a pesquisa mostra que $38,8 \%$ dos trabalhadores bancários encontram-se na faixa etária de 25 a 34 e que apenas $6,5 \%$ encontra-se abaixo desta faixa.

No tocante à questão racial, o Censo mostra que os funcionários são predominantemente caucasianos, conforme mostrado na Figura 4 a seguir. A região em que a diferença está mais presente é a sul em que 91,6\% dos funcionários são caucasianos, 8\% são 
negros. Na região norte o cenário encontrado é oposto à região sul, já que $57,3 \%$ dos funcionários são negros e 42,2\% são caucasianos. A região nordeste apresenta $49,9 \%$ dos funcionários que se declararam caucasianos e 49,6\% como negros.

Figura 4. Distribuição dos bancários por raça

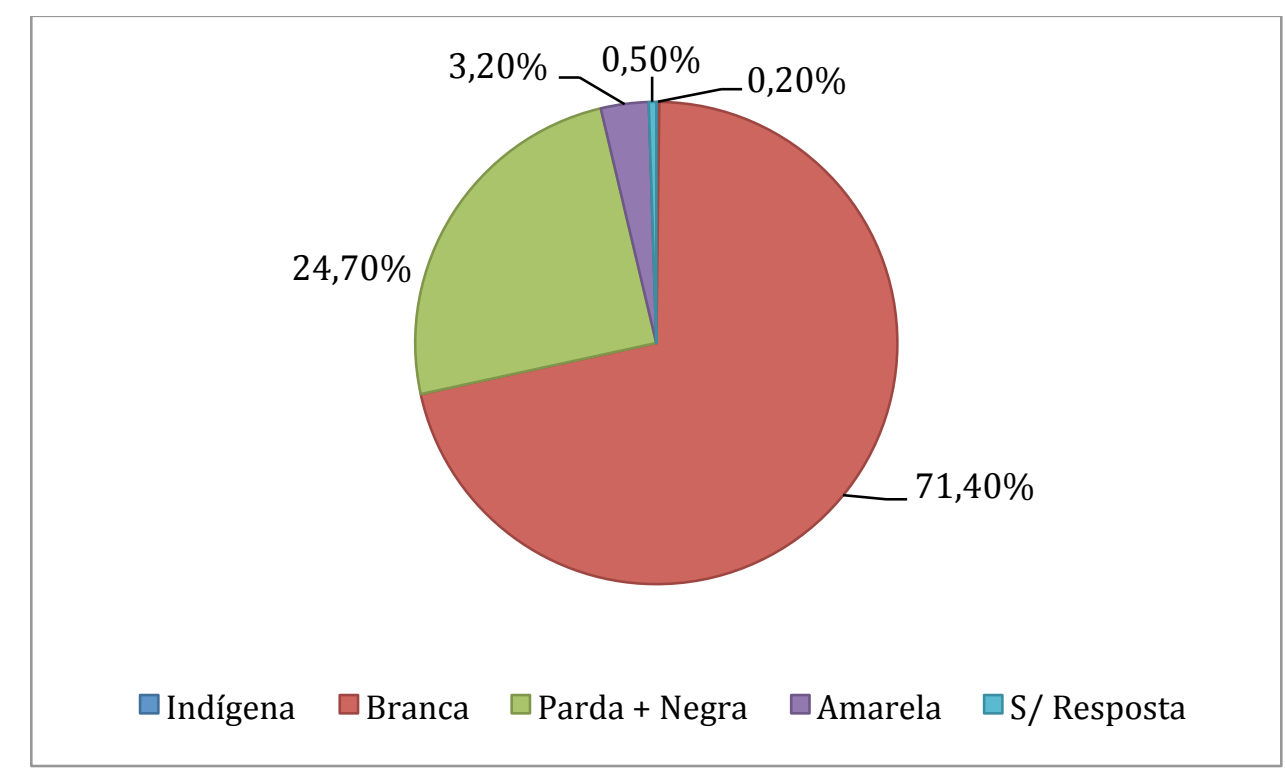

Fonte: Elaborado pela autora a partir dos dados do Censo da Diversidade (2014).

No entanto, o censo da diversidade de 2008 apresentava 19\% de negros e 16,7\% de pardos. Para 2014, o quadro representativo passou para $24,7 \%$ de negros e $21,3 \%$ de pardos. Ou seja, apresentou uma melhoria rumo a igualdade de oportunidades aos quesitos raciais.

Outro dado importante a ser destacado é a presença de Pessoas com Deficiência (PCD) no quadro de funcionários dos bancos. Em 2008 apenas 1,8\% dos funcionários tinha algum tipo de deficiência, já em 2014 esse número dobrou para 3,6\%, sendo que a deficiência física é a mais encontrada, representando $60,7 \%$ dos casos.

Para possibilitar o acesso tanto de clientes quanto de funcionários com deficiência os bancos são obrigados a passar por modificações para tornarem-se adequados e acessíveis, contudo, não são todos aderentes à essas exigências. A média brasileira de agências adequadas está em 78,5\%, sendo a região sudeste com maior número de agências, totalizando $81,1 \%$, e a região norte a com menor número, com um total de $72 \%$.

Quanto ao conhecimento das vagas ofertadas pelos bancos, a Tabela 2 a seguir representa as diferenças entre o censo de 2008 e 2014 : 
Tabela 2. Conhecimento das Vagas de Emprego do Setor Bancário Brasileiro

\begin{tabular}{lcc}
\hline & Conhecimento da Vaga de Emprego & \\
\hline & $\mathbf{2 0 0 8}$ & $\mathbf{2 0 1 4}$ \\
Anúncios de jornal/revista & 6,8 & 6,1 \\
Internet & 4,1 & 8,6 \\
Edital de Concurso & 17,8 & 21,2 \\
Cartazes e mala direta & 0,1 & 0,6 \\
Por amigos e parentes & 30,7 & 29 \\
Por funcionário do banco & 28,3 & 22,6 \\
Agência/empresa de recrutamento & 3,2 & 4,6 \\
Outros & 8,6 & 6,9 \\
\hline
\end{tabular}

Outro aspecto de destaque é referente à escolaridade na distribuição dos bancários. De 2008 para 2014 houve um aumento no nível de escolaridade dos colaboradores, onde as taxas de pessoas com superior incompleto caíram de $25,1 \%$ para $16,2 \%$, e as taxas de acima de superior completo passaram de $24,6 \%$ para $36,3 \%$.

Nota-se que muitas mudanças estão ocorrendo no setor. O item a seguir mostra um pouco mais das transformações no setor bancário e sua força de trabalho ao longo dos anos.

\subsubsection{GESTÃO DE PESSOAS NO SETOR BANCÁRIO}

O setor bancário brasileiro sofreu ao longo das últimas décadas um processo de reestruturação intenso devido ao avanço tecnológico e modificações organizacionais (SILVA e NAVARRO, 2012).

Após a implantação do Plano Cruzado, houve a primeira fase de reestruturação produtiva do setor, com uma grande onda de demissões. Junto à isso, um intenso investimento em automação e informática, visando reduzir os custos e agilizar o atendimento, antecedeu a segunda fase: do Plano Collor, que foi caracterizada pela intensificação desses fatores (SILVA et al., 2007).

A fase mais recente conta com a redução dos níveis hierárquicos, a flexibilidade e polivalência exigida pelas novas funções. Os bancários passaram a cumprir um papel de exímios vendedores, sendo cobrados pelo cumprimento das metas estabelecidas pelos níveis hierárquicos superiores, e responsáveis por atividades como consultorias financeiras e a comercialização de produtos e serviços (LARANGEIRA, 1997; GRAVINA e ROCHA, 2006).

Segnini (1999) trouxe que fenômenos sociais como desemprego, precarização do trabalho e a intensificação do ritmo laboral foram algumas consequências das novas 
exigências e qualificações que o setor passou a demandar. Com isso, a instituição bancária passou a contratar jovens em início de carreira, com pouca experiência profissional, por ser também uma atividade com remuneração um pouco mais elevada que outros setores, em cidades principalmente onde a oferta de empregos não é muito ampla, passou a ser uma oferta atrativa (SILVA e NAVARRO, 2012).

E tanto a mudança do perfil do bancário, quanto a chegada da informatização, contribuíram muito para o surgimento de adoecimentos ocupacionais, devido à intensificação do trabalho (GRAVINA e ROCHA, 2006). A elevação da incidência de sofrimento mental e sensação de perda de identidade profissional são algumas das queixas trazidas pelos trabalhadores, de acordo com Silva e Navarro (2012), bem como sentimentos de frustração, insegurança, pressão psicológica.

Ao mesmo tempo em que esses fatores são evidenciados, empresas como Itaú Unibanco e Banco Bradesco são classificadas pela Você S/A (2013), como melhores empresas para se trabalhar, sendo as duas com mais de 80 mil funcionários. O Great Place to Work, uma empresa de pesquisa, consultoria e treinamento, ajuda as organizações a criarem e manterem ambientes de trabalho agradáveis, criando um ciclo de contribuição e reconhecimento pessoal, que geram desempenhos empresariais melhores. $\mathrm{Na}$ lista das melhores empresas algumas do setor aparecem, como: Bradesco, nos anos 2012, 2013; Banco do Brasil em 2011; Itaú em 2010 e 2013, entidades estudadas nesse trabalho (GPTW, 2014).

Muitos estudos mostram a preocupação do setor bancário frente à sustentabilidade se pauta majoritariamente na questão ambiental, pois ao investir no desenvolvimento econômico de outras organizações, o risco ambiental afeta diretamente no retorno financeiro das mesmas, o que indiretamente atinge os bancos (INFANTE et al., 2010). Andrade et al. (2011) trazem que a responsabilidade social corporativa dessas instituições são apresentadas mais como reputação organizacional e reforço da imagem, não demonstrando uma preocupação real com seu público interno e sim com uma relação de ganho unilateral.

O setor bancário apresenta inúmeras iniciativas acerca de debates sobre finanças sustentáveis, como os Princípios do Equador, o Protocolo Verde, a Declaração de Collevecchio, entre outras que serão mais bem exploradas no Quadro 14 a seguir. 
Quadro 14 - Iniciativas sobre finanças sustentáveis.

\begin{tabular}{|c|c|c|}
\hline INICIATIVA & DEFINIÇÃO & AUTORES \\
\hline Protocolo Verde & $\begin{array}{l}\text { Acordo afirmado entre bancos públicos e privados para implementarem } \\
\text { medidas socioambientais no setor. "No protocolo, que funciona como } \\
\text { uma carta de intenções, os bancos se comprometem a empreender } \\
\text { políticas e práticas bancárias que sejam precursoras, multiplicadoras, } \\
\text { demonstrativas ou exemplares em termos de responsabilidade } \\
\text { socioambiental. E que também estejam em harmonia com o objetivo de } \\
\text { promover um desenvolvimento que não comprometa as necessidades das } \\
\text { gerações futuras." }\end{array}$ & $\begin{array}{l}\text { BRASIL } \\
(2009) \text {. } \\
\text { FEBRABAN, } \\
(2011)\end{array}$ \\
\hline $\begin{array}{l}\text { Declaração de } \\
\text { Collevecchio }\end{array}$ & $\begin{array}{l}\text { O documento, elaborado na cidade de Collevecchio e apresentado em } \\
2003 \text { no Fórum Econômico Mundial, delineia o papel que o setor } \\
\text { financeiro tem em promover a sustentabilidade, convocando-o a } \\
\text { trabalhar temas como impactos, responsabilidade, transparência, } \\
\text { prestação de contas e governança corporativa. }\end{array}$ & $\begin{array}{l}\text { FEBRABAN, } \\
(2007) .\end{array}$ \\
\hline $\begin{array}{l}\text { Princípios do } \\
\text { Equador }\end{array}$ & $\begin{array}{l}\text { É um framework de gestão de risco, adotadas por instituições } \\
\text { financeiras, para determinar, avaliar e gerenciar riscos sociais e } \\
\text { ambientais em projetos. Destina-se principalmente a fornecer um padrão } \\
\text { mínimo de apoio a tomada de decisão de risco responsável. }\end{array}$ & $\begin{array}{l}\text { EQUATOR } \\
\text { PRINCIPLES, } \\
(2014) .\end{array}$ \\
\hline $\begin{array}{l}\text { United Nations } \\
\text { Environment } \\
\text { Programme } \\
\text { Finance Initiative }\end{array}$ & $\begin{array}{l}\text { Criada em 1992, como uma plataforma para associar as Nações Unidas e } \\
\text { o setor financeiro global. Trabalha com a colaboração de mais de } 200 \\
\text { membros, que assinaram o Termo de Compromisso UNEP-FI, sendo } \\
\text { compostos por instituições financeiras públicas e privadas de todo o } \\
\text { mundo (países desenvolvidos e em desenvolvimento). }\end{array}$ & $\begin{array}{l}\text { UNEP-FI } \\
(2014) .\end{array}$ \\
\hline $\begin{array}{l}\text { Câmara Temática } \\
\text { de Finanças } \\
\text { Sustentáveis } \\
\text { (CTFIN) do } \\
\text { Conselho } \\
\text { Empresarial } \\
\text { Brasileiro para o } \\
\text { Desenvolvimento } \\
\text { Sustentável } \\
\text { (CEBDS). }\end{array}$ & $\begin{array}{l}\text { Fundada em 1997, O CEBDS é uma associação civil sem fins lucrativos } \\
\text { que promove o desenvolvimento sustentável, nas empresas que atuam no } \\
\text { Brasil, por meio da articulação junto aos governos e a sociedade civil } \\
\text { além de divulgar os conceitos e práticas mais atuais do tema. Criado a } \\
\text { partir da Rio } 92 \text { por um grupo de empresários, traz na Câmara Temática } \\
\text { de Finanças Sustentáveis a preocupação com o papel fundamental ao } \\
\text { conceder créditos e financiar empreendimentos que não sejam pautados } \\
\text { em evitar os impactos socioambientais. }\end{array}$ & CEBDS (2014). \\
\hline
\end{tabular}

Fonte: Elaborado pela autora.

Percebe-se que mesmo essas iniciativas estando engajadas com a preocupação socioambiental, as práticas trabalhistas são muito pouco exploradas por elas. O setor bancário brasileiro se envolve de maneira mais intensa na questão de financiamentos e empréstimos, o que não apresenta um panorama total de todas as práticas que poderiam ser recorrentes, já que os colaboradores quase não são citados.

Dessa forma, estudar as questões trabalhistas, objetivo desta pesquisa, é analisar se existe um total respeito, do setor bancário, frente à legislação trabalhista. Além de verificar o panorama atual de ações realizadas pelo setor que incluem a preocupação com seus trabalhadores. 


\section{PROCEDIMENTOS METODOLÓGICOS}

Neste capítulo, apresentam-se os procedimentos metodológicos da pesquisa e as etapas de seu desenvolvimento. Num primeiro momento, encontra-se a descrição da classificação geral da pesquisa, logo em seguida a descrição das etapas, da coleta e da análise dos dados, e por fim, as proposições a serem avaliadas.

\subsection{CLASSIFICAÇÃO GERAL DA PESQUISA}

A pesquisa foi quanto aos fins, de natureza descritiva, que visa descrever características do mercado, no caso deste trabalho, do setor bancário brasileiro. Este tipo de pesquisa é utilizado por ser guiada por hipóteses ou questões investigativas declaradas (MALHOTRA, 2012; COOPER E SCHINDLER, 2011).

É também utilizada para atender aos seguintes objetivos: i) descrição de fenômenos ou características ligadas com a população-alvo; ii) estimativa das proporções de uma população que tenha essas características; iii) descoberta de associações entre as diferentes variáveis (COOPER E SCHINDLER, 2011). Neste aspecto, este estudo visa explorar a relação entre as práticas de gestão de pessoas do setor bancário brasileiro, o que é abordado pela Gestão Sustentável de Pessoas e os acórdãos trabalhistas.

Quanto à natureza do método, esta pesquisa se caracteriza em duas abordagens: qualitativa e quantitativa. A primeira é capaz de proporcionar uma compreensão e visão melhor no contexto da problemática, diferente da quantitativa que pode traduzir informações e opiniões em números para classificá-las e analisá-las, com necessidade de recursos e análises estatísticas (MALHOTRA, 2012; MORESI, 2003).

A qualitativa está pautada em toda análise de conteúdo, na triangulação de dados, e na categorização, que são técnicas que serão melhores descritas no próximo item. A quantitativa visou organizar, sumarizar, e melhorar a apresentação dos dados encontrados nos acórdãos trabalhistas.

Como Triviños (1987) alega, a abordagem de cunho qualitativo trabalha buscando o significado dos dados, baseado na percepção do fenômeno dentro do seu conjunto. Ela procura captar não só a aparência, mas também a essência, a origem, tentando intuir as consequências. Já a abordagem quantitativa tende a caracterizar a variabilidade intrínseca a qualquer processo que esteja qualificado por interações sociais (XIE, 2005). 


\subsection{ETAPAS DA PESQUISA}

$\mathrm{Na}$ Figura 5 a seguir, estão expostas esquematicamente em ordem temporal as etapas que estruturaram essa pesquisa, cujo detalhamento se encontra nos tópicos seguintes.

Figura 5 - Etapas da pesquisa.

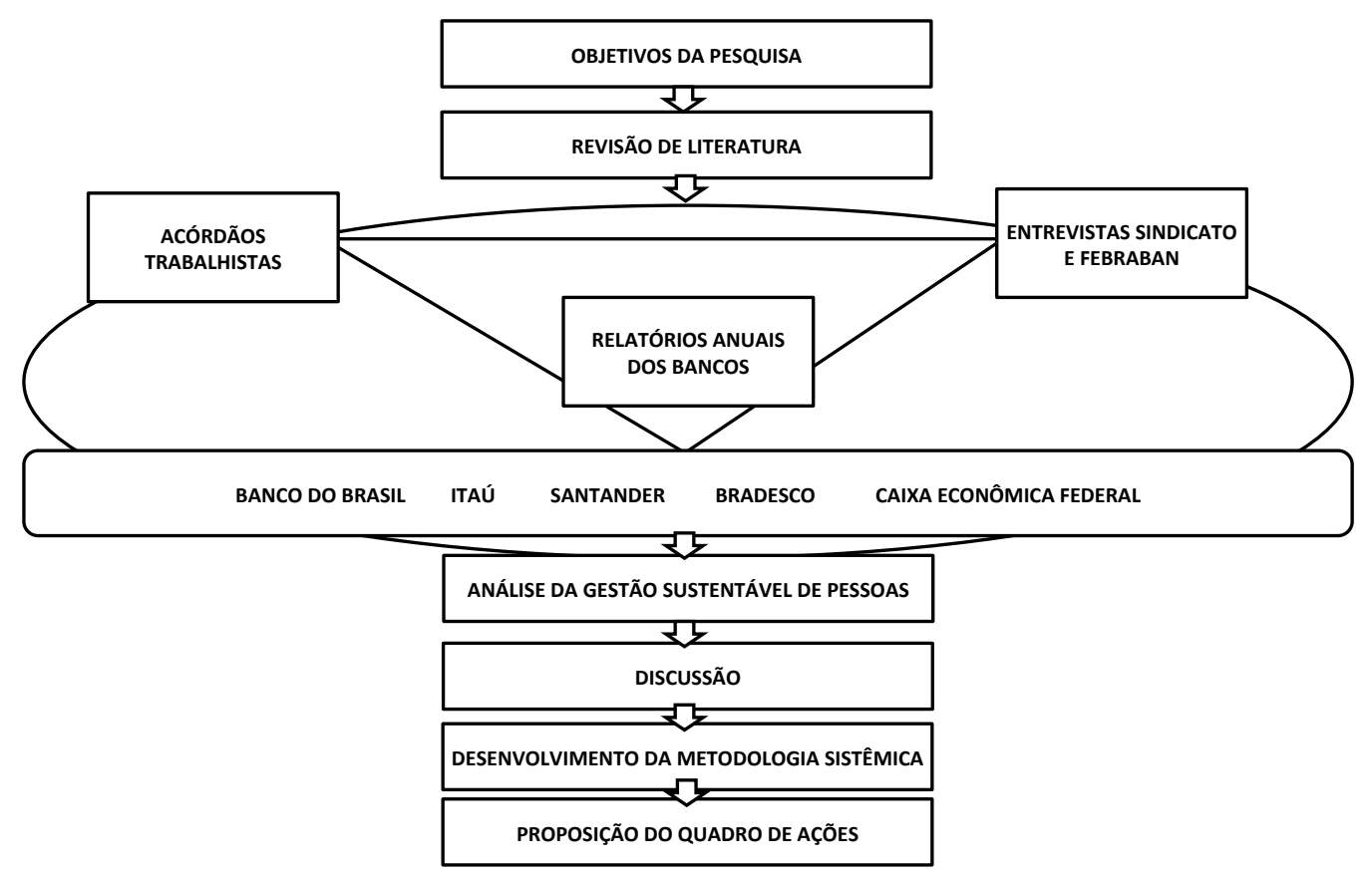

Fonte: Elaborada pela autora.

\subsection{OBJETIVOS DA PESQUISA E REVISÃO DE LITERATURA}

As duas primeiras etapas foram realizadas em um processo interativo para conhecer melhor o problema da pesquisa, ao mesmo tempo em que aumentava a densidade teórica para analisá-lo criticamente.

Na primeira etapa foi realizada a definição da temática, do problema de pesquisa, e da metodologia que foi utilizada. Houve uma investigação bibliográfica a fim consolidar essas decisões, baseada em dados, conceitos e informações de livros, sites institucionais e setoriais, teses e dissertações, além de artigos científicos indexados em bases acadêmicas, como Scopus, Science Direct, Scielo, Anpad, Jstor e Emerald Insight. A partir do processo de sínteses dessas fontes coletadas emerge a Revisão de Literatura apresentada no capítulo 2. 


\subsection{PROPOSIÇÕES DA PESQUISA}

Diante de tudo que foi exposto até o momento, algumas proposições foram sugeridas a fim de permitir a articulação entre os pressupostos teóricos do estudo e os dados da realidade, sistematizando a coleta de dados e beneficiando sua análise (MARTINS e THEÓPHILO, 2009).

Tem sido evidente que a consciência pública sobre a importância da organização no desenvolvimento sustentável, vem crescendo, assim como o incentivo para que as atividades de sustentabilidade sejam reportadas cada vez mais (EHNERT et al., 2015). Concomitante à esse crescimento, os mesmos autores trazem que a Gestão Sustentável de Pessoas ou Sustainable Human Resources Management, também vem sendo cada vez mais explorada.

Ehnert et al. (2015) ainda alega que com a sensibilização da opinião pública global frente aos problemas ecológicos, sociais e econômicos das empresas, cada vez mais tem gerado comprometimento em demonstrar suas ações com responsabilidade. Logo, a gestão de pessoas - entendida com processos relativos ao pilar social do TBL voltados o público interno - não pode ficar alijada desse processo.

Diante desse exposto, a seguinte proposição foi elaborada para atingir o objetivo específico de conhecer as práticas de gestão de pessoas reportadas pelos bancos:

P1. Os relatórios reportados pelas organizações do setor bancário brasileiro contemplam os tópicos dos subsistemas de gestão de pessoas.

Dentro das práticas de gestão de pessoas, a temática da qualidade de vida vem ganhando destaque, principalmente a partir dos anos 90. Mudanças demográficas acentuam essa questão, como a busca da geração Y por mais liberdade nas suas ações e a importância do equilíbrio entre a vida profissional e a vida pessoal: uma perspectiva de crenças e atitudes notadamente diferentes das demais gerações (GOLIK, 2013).

As mudanças introduzidas pela qualidade de vida como um novo pilar nas expectativas dos funcionários em relação emprego, abriu um série de reflexões acerca das políticas e práticas que as organizações endossam nos seus sistemas de gestão. Por outro lado, a competitividade tem promovido a intensificação do trabalho, colocando as políticas de recursos humanos em suspensão: se por um lado a produtividade da empresa vai aumentar, e possivelmente a remuneração dos funcionários também, por outro lado existe a exaustão física e mental do trabalhador (GOLIK, 2013; SOUZA et al., 2015).

Com a intensificação do trabalho, as pessoas acabam trabalhando mais do que o limite de 44 horas semanais determinadas pela (Consolidação das Leis do Trabalho). E isso não constitui fato isolado e esporádico, elas acabam por sair das empresas em decorrência da 
deterioração progressiva da qualidade de vida. Além disso, o clima de competição que as organizações enfrentam, apresentam um ambiente pouco saudável para os colaboradores (SOUZA et al., 2015). Os desdobramentos desse quadro alçam a esfera pessoal, com o comprometimento das relações familiares.

Assim, os empregados, quando submetidos à essa condição de trabalho, saem das organizações e recorrem à Justiça após suas demissões a fim de serem ressarcidos. As principais ocorrências de reclamações trabalhistas se pautam nas horas extras, e na equiparação da remuneração, respeitando as diversidades de gênero, raça, idade, nacionalidade, evitando qualquer tipo de discriminação que possa ocorrer (APPEL e BITENCOURT, 2008).

Desse modo, a segunda proposição elaborada a partir do segundo objetivo específico de levantar os acórdãos trabalhistas do setor bancário brasileiro no ano de 2014 é:

\section{P2. O desequilibrio entre a vida profissional e a vida pessoal resultam em queixas}

\section{trabalhistas.}

Diante dessas reclamações trabalhistas, e das novas exigências advindas dos stakeholders, as organizações precisam estar em constantes modificações e melhorias, integrando-as em suas políticas e ações.

Ao unir as práticas de gestão de pessoas à preocupação com a força de trabalho interna das organizações, a implicação se dá em integrar o papel de coordenar os aspectos externos da Gestão Sustentável de pessoas às atividades cotidianas internas (EHNERT et al., 2015).

Com os conceitos envolvendo a sustentabilidade organizacional, que abrange o triple bottom line, um intenso debate vem ocorrendo entre consultores, gestores de empresas, acadêmicos, onde a busca por definições de como fazer negócios tem sido cada vez mais ético, transparente e mais humano (van MARREWIJK, 2003).

Ehnert et al. (2015) traz que as maiores empresas do mundo tem se preocupado com as dimensões internas, que envolvem a Gestão Sustentável de Pessoas, no qual elas têm apresentado em seus relatórios questões envolvendo quesitos de trabalho e trabalho decente, indicadores referentes à gestão de pessoas e como as ações afetam seus colaboradores.

As empresas, ao tratar do tema da sustentabilidade, tem demonstrado que suas políticas já incluem a temática, e que já existem diversos projetos e iniciativas que apoiam essa posição e compromisso (EWEJE, 2011).

Assim, a área de gestão de pessoas pode redefinir e alargar seu âmbito, aumentando sua importância estratégica ao contribuir para a gestão e medição dos impactos sociais e 
ecológicos advindos das corporações, implicando em redesenhos que poderiam ser usados como referência de critérios de Gestão Sustentável de Pessoas (EHNERT et al., 2015).

A busca por informações em dados secundários, como ocorrido nos acórdãos trabalhistas e nos relatórios dos bancos analisados neste trabalho, requer um panorama mais aprofundado de quem está vivenciando no dia-a-dia as mudanças, melhorias e a evolução das práticas de gestão de pessoas do setor bancário brasileiro.

Assim, para identificar quais delas o setor tem aderido, elencando quais práticas poderiam ser consideradas dentro dos conceitos de Gestão Sustentável de Pessoas, foram realizadas entrevistas com o Sindicato dos Bancários e Financiários de São Paulo, Osasco e Região e da Federação Brasileira de Bancos, o que permitiu a formulação da seguinte proposição:

P3. O setor bancário brasileiro tem integrado a sustentabilidade em suas ações de gestão de pessoas.

Ainda tratando da Gestão Sustentável de Pessoas, por ser um conceito emergente, com amplas possibilidades de contribuição para a gestão nas organizações, a utilização dos relatórios de sustentabilidade corporativa podem ser um caminho onde as empresas reportam e refletem sobre suas ações em direção a um ideal de Gestão Sustentável de Pessoas (EHNERT et al., 2015).

$\mathrm{Na}$ literatura e na prática, ainda existe uma lacuna entre o conceito de sustentabilidade organizacional e as estratégias adotadas para que ela seja implementada no dia-a-dia das operações, principalmente levando em consideração a visão sistêmica do negócio (CHENG et al., 2010).

Embora estudiosos estejam cada vez mais interessados na Gestão Sustentável de Pessoas, mais pesquisas são necessárias para dar forma a este conceito e desenvolver um guia de implicações práticas que sejam claras e objetivas para serem seguidas, ou seja, muitos trabalhos tem sido mais conceituais e menos de natureza exploratória (EHNERT et al., 2015).

\subsection{TRIANGULAÇÃO DE DADOS}

Dado o caráter exploratório da pesquisa, foi adotada uma abordagem de triangulação dos dados com objetivo de compreender de forma mais rica o problema da pesquisa e abarcar os diferentes atores envolvidos. Jack e Raturi (2006) explicam que dentre as formas de utilização da técnica, cinco são possíveis:

(i) triangulação de dados, onde diversas formas de se coletar e analisar os dados envolvem tempo, espaço e pessoas; 
(ii) triangulação múltipla, utilizando distintos observadores, perspectivas teóricas, metodologia e fontes de dados;

(iii) triangulação de investigadores, quando mais de um observador realiza a análise;

(iv) triangulação teórica, com mais de um esquema teórico para interpretar os fenômenos; e a última,

(v) triangulação metodológica, na qual é utilizada mais de uma fonte de dados qualitativa ou quantitativa, ou mesmo mais de um método em uma única pesquisa. Sendo esta última a utilizada nesta pesquisa.

Para o presente estudo, a coleta de dados dos relatórios anuais ou de sustentabilidade (qualitativa), dos acórdãos trabalhistas (quantitativa), bem como das entrevistas no Sindicato e na Febraban (qualitativa), caracterizam-no como triangulação metodológica. A importância dessa técnica, segundo Martins e Theóphilo (2009), se dá em uma análise mais completa dos fatos, por combinar diferentes formas de coleta e análise de dados, visando confirmar as conclusões alcançadas por meio da compreensão e interpretação de um fenômeno.

\subsubsection{RELATÓRIOS ANUAIS OU DE SUSTENTABILIDADE}

A etapa de levantamento dos relatórios anuais ou de sustentabilidade neste trabalho abrangeu: Banco do Brasil, Caixa Econômica Federal, Santander, Itaú e Bradesco. Essa amostra foi definida através do ranking dos maiores bancos de varejo de 2013 publicado pelo Banco Central do Brasil (BACEN), e o parâmetro utilizado foi a seleção das cinco primeiras posições relativas aos maiores ativos totais. A busca dos relatórios foi feita por meio do website oficial da instituição Global Reporting Initiative (GRI), sendo o filtro selecionado o ano de 2013 e a diretriz G4 do GRI.

Os relatórios encontrados foram classificados como relatórios anuais com exceção do relatório da Caixa Econômica Federal, que foi classificado por eles como relatório de sustentabilidade.

As organizações costumavam divulgar relatórios que contemplavam apenas seus resultados financeiros. Paralelo à essa divulgação, uma cultura de relatórios de sustentabilidade foi instalado nos últimos anos, envolvendo as ações sociais (internas e externas) e as ambientais. O modelo de relatório anual surge com o intuito de integrar todos os âmbitos (social, econômico, ambiental e de governança) em um mesmo relatório, para facilitar aos stakeholders a comunicação dos resultados e a tomada de decisão. 
Apesar do Global Reporting Initiative ter sido difundido como um tipo de relatório de sustentabilidade, ele apresenta as diretrizes para cada âmbito, como sugestões para as organizações seguirem em suas atividades e reportarem aos seus stakeholders.

Dos relatórios utilizados, todos os bancos exceto a Caixa Econômica Federal, utilizaram o modelo de relatório anual, contemplando o tripé - social, ambiental e econômico. A CEF, apresenta seus dados econômico-financeiros de maneira mais sucinta, focando mais nas ações de âmbito social e ambiental.

Destes relatórios foram extraídas informações referentes as práticas, ações e iniciativas acerca dos subsistemas de gestão de pessoas: recrutamento e seleção, treinamento e desenvolvimento, sistemas de pagamento e recompensa, envolvimento empregatício, empowerment e engajamento, saúde, segurança e qualidade de vida no trabalho, gestão de desempenho e avaliação, e as metas e desafios encontrados para os próximos anos.

Essa coleta é denominada como pesquisa documental, que segundo Lakatos e Marconi (2001), é a coleta de dados em fontes primárias, como documentos escritos ou não, pertencentes a arquivos públicos, arquivos particulares de instituições, entre outros.

Essa etapa também é conhecida por Bardin (2009) como a primeira fase da análise de conteúdo, denominada pré-análise. É o momento de organizar o material a ser analisado, demarcando os itens a serem estudados, formulando as categorias a serem investigadas. Neste momento, surgem as questões norteadoras do estudo frente as teorias já conhecidas.

Assim, diante da revisão de literatura de gestão de pessoas, as práticas de cada banco foram descritas baseadas em cada subsistema da área. Essa parte do trabalho pode ser encontrada nos resultados.

\subsubsection{ACÓRDÃOS TRABALHISTAS}

Nessa etapa foram selecionados os acórdãos trabalhistas relacionados aos mesmos bancos, no Tribunal Regional do Trabalho da $2^{\text {a }}$ Região de São Paulo, através do website: http://www.trtsp.jus.br/pesquisa-jurisprudencia-por-palavra-acordaos.

Acórdãos representam de maneira sucinta a conclusão a que se chegou de um processo proferido por órgãos colegiados de um Tribunal. Esse nome advém da tomada de decisão realizada em acordo com todos os membros do colegiado, o que o diferencia da sentença que é definida por apenas um julgador. Normalmente apresentam os principais pontos levantados pelos requerentes do processo, e se as decisões foram aprovadas, aprovadas parcialmente ou negadas. 
No campo pesquisa os nomes dos bancos foram buscados entre aspas, a fim de refinar as buscas. O período de publicação dos acórdãos foi restringido entre as datas de 01/01/2014 a $31 / 12 / 2014$.

Mesmo os relatórios disponíveis no database do GRI serem do ano de 2013, o ano de 2014 foi escolhido pois as decisões colegiadas independem do tempo que se leva para compor e publicar um acórdão, ou seja, os finalizados no último ano não significam que foram solicitados neste mesmo ano (STF, 2015).

Deste período foram encontrados os seguintes números de acórdãos:

Tabela 3. Número de acórdãos encontrados primeira etapa

\begin{tabular}{lllll}
\hline Banco do Brasil & Itaú Unibanco & $\begin{array}{l}\text { Caixa Econômica } \\
\text { Federal }\end{array}$ & Santander & Bradesco \\
\hline 1.720 & 3.310 & 2.760 & 2.950 & 1.720 \\
\hline
\end{tabular}

Cada um desses acórdãos passou por uma análise preliminar e teve seu conteúdo verificado, pois casos como processos em segredo de justiça e outros processos que não condiziam diretamente aos bancos, eram retidos na amostra porque a guia de recolhimento deveria ser paga nesses bancos. Ou seja, constava na amostra inicial acórdãos que não representavam o escopo dessa pesquisa. Assim, a amostra foi reduzida para os seguintes números com a eliminação desses processos:

Tabela 4. Número de acórdãos encontrados segunda etapa

\begin{tabular}{lllll}
\hline Banco do Brasil & Itaú Unibanco & $\begin{array}{l}\text { Caixa Econômica } \\
\text { Federal }\end{array}$ & Santander & Bradesco \\
\hline 398 & 589 & 584 & 310 & 246 \\
\hline
\end{tabular}

Foi realizado um teste piloto com o Banco do Brasil, onde os 398 acórdãos foram analisados, para levantar categorizações que permitissem agrupar os processos. $\mathrm{Na}$ análise, as categorias foram extraídas por meio da análise de conteúdo (BARDIN, 2009) e posteriormente, foram validadas por uma profissional da área de Direito, que ratificou quais ocorrências estariam relacionadas a área de gestão de pessoas, e quais eram relativas à questões do próprio processo. As categorias analisadas neste trabalho estão apresentadas no Quadro 15 a seguir. 
Quadro 15 - Categorias analisadas nos Acórdãos

\begin{tabular}{|c|c|}
\hline \multicolumn{2}{|c|}{ CATEGORIAS ANALISADAS NOS ACÓRDÃOS } \\
\hline Acúmulo de Função & Gratificação de Função \\
\hline Adicional de Horas Extras & Horas de Sobreaviso \\
\hline Adicional de Insalubridade / Periculosidade & Horas Extras \\
\hline Adicional de Transferência & Indenizações \\
\hline Adicional Noturno & INSS / Assistência Médica / Plano de Saúde \\
\hline Ausências Permitidas & Jornada de Trabalho \\
\hline Auxílios & Justa Causa \\
\hline Base de Cálculo das Horas Extras & Multas Normativas / Convencionais \\
\hline Comissões & Multas Rescisórias \\
\hline Complementação de Aposentadoria & Participação no Lucros e Resultados (PLR) \\
\hline Contribuições Assistenciais & Plano de Demissão Voluntária (PDV) \\
\hline Contribuições Previdenciárias e Fiscais / IR - Juros & Quilômetros Rodados \\
\hline Depósitos de FGTS & Reajustes Salariais \\
\hline Devolução de Descontos / Dedução de Valores & Rescisão Contratual / PDV \\
\hline Diferenças de FGTS $+40 \%$ & Redução Salarial \\
\hline Diferenças Salariais & Reembolso com Requalificação Especial \\
\hline Doença Profissional & Reflexos / Horas Extras \\
\hline Enquadramento Sindical & Retificação da CTPS \\
\hline Equiparação Salarial & Reversão de Pedido de Demissão \\
\hline Estabilidade Provisória & Unicidade Contratual \\
\hline Férias & Verbas Rescisórias / Base de Cálculo Salarial \\
\hline FGTS - Incidências sobre Comissões & Vínculo Empregatício / Condição de Bancário \\
\hline Frequência Livre / Dirigente Sindical & \\
\hline
\end{tabular}

Fonte: Elaborado pela autora.

Por outro lado, as seguintes causas foram excluídas da amostra desta pesquisa:

Quadro 16 - Categorias excluídas para a análise

\begin{tabular}{|l|l|}
\hline \multicolumn{2}{|c|}{ CATEGORIAS EXCLUÍDAS PARA ANÁLISE } \\
\hline Aditamento a inicial & Justiça Gratuita \\
\hline Agregamento & Legitimidade de parte \\
\hline Alteração do valor dado à causa/alterações contratuais & Multa litigância de má-fé \\
\hline Cerceamento de defesa & Multas por embargos protelatórios \\
\hline Competência da Justiça de Trabalho & Prescrição \\
\hline Correção monetária e Juros & Prestação Jurisdicional \\
\hline Expedição de Ofícios & Responsabilidade solidária e subsidiária \\
\hline Honorários Advocatícios e Periciais & Substituição Processual \\
\hline Ilegitimidade da parte e passiva & Suspeição de testemunhas \\
\hline & Tutela antecipada e inibitória \\
\hline
\end{tabular}

Fonte: Elaborado pela autora.

A amostra final passou para os seguintes números: 
Tabela 5. Número final de acórdãos encontrados e analisados

\begin{tabular}{lllll}
\hline Banco do Brasil & Itaú Unibanco & $\begin{array}{l}\text { Caixa Econômica } \\
\text { Federal }\end{array}$ & Santander & Bradesco \\
\hline 268 & 383 & 293 & 199 & 192 \\
\hline
\end{tabular}

Assim, para fins de comparação, segue a Tabela 6 com o número de funcionários de cada banco e de seus respectivos número de acórdãos encontrados:

Tabela 6. Número de funcionários versus número de acórdãos encontrados

\begin{tabular}{llll}
\hline & $\begin{array}{l}\text { Número de } \\
\text { funcionários }\end{array}$ & $\begin{array}{l}\text { Número de } \\
\text { acórdãos }\end{array}$ & $\begin{array}{l}\text { Proporção }\left(\mathbf{n}^{\circ} \text { de funcionários } / \mathbf{n}^{\circ} \text { de }\right. \\
\text { acórdãos) }\end{array}$ \\
\hline $\begin{array}{l}\text { Banco do Brasil } \\
\text { Itaú Unibanco }\end{array}$ & 112.216 & 268 & $0,23 \%$ \\
Caixa Econômica & 95.696 & 383 & $0,40 \%$ \\
Federal & 164.300 & 293 & $0,17 \%$ \\
Santander & 47.999 & 199 & $0,19 \%$ \\
Bradesco & 100.489 & 192 & $0,41 \%$ \\
Total & 520.700 & 1.335 & $0,25 \%$ \\
\hline
\end{tabular}

Após esse processo de refinamento da amostra, todos os acórdãos foram então analisados e classificados dentro das categorias estabelecidas no teste piloto.

As análises estatísticas, mais precisamente a estatística descritiva utilizada, visou organizar, sumarizar e descrever o conjunto de dados, culminando na construção de gráficos e tabelas (MARTINS e THEÓPHILO, 2009). A análise descritiva foi pautada na distribuição por frequência, que de acordo com Malhotra (2012) objetiva contar o número de respostas associadas a diferentes valores de uma variável, que nessa pesquisa são as categorizações, expressando-as em percentagens.

\subsubsection{SINDICATO E FEBRABAN}

Além das duas etapas supracitadas, a triangulação dos dados contou uma terceira fonte de informações: foram realizadas duas entrevistas com instituições representantes das grupos envolvidos na problemática que se insere a pesquisa, uma com o Sindicato dos Bancários e Financiários de São Paulo, Osasco e Região representando os funcionários e outra com a Federação Brasileira de Bancos (Febraban) representando os empregadores.

As entrevistas foram semiestruturadas, com um roteiro de apoio com os pontos primordiais a serem abordados, com intuito de captar a percepção dos entrevistados. O foco 
da entrevista foi na gestão de pessoas no setor bancário e suas interfaces com a sustentabilidade, permitindo ao entrevistado responder de maneira aberta sobre o assunto. $\mathrm{O}$ papel das entrevistas foi contribuir na compreensão dos significados que os entrevistados atribuem à temática pesquisada, identificando os aspectos considerados por eles mais importantes (GODOY, 2010; FLICK, 2008; RICHARDSON et al., 1989). O roteiro da entrevista pode ser encontrado no Apêndice A.

A análise de conteúdo também foi uma metodologia usada nessa etapa, visando enriquecer a leitura dos dados encontrados. Bardin (2009) afirma que a exploração do material consiste na exploração do conteúdo frente as categorias pré-definidas. Além dessa etapa, houve a fase de condensar e destacar as informações, dentro do que cabia aos subsistemas de gestão de pessoas estabelecidos para analisar neste trabalho, permitindo uma análise reflexiva e crítica.

Esta etapa serviu de complementação na busca de informações a respeito da temática deste trabalho, permitindo maior profundidade nas inferências propostas.

\subsection{ANÁLISE DA GESTÃo SUSTENTÁVEL DE PESSOAS}

A fim de propor a integração dos conceitos e conhecimentos acerca da Gestão Sustentável de Pessoas com a realidade, a metodologia sistêmica Soft System Methology (SSM) foi utilizada. Essa metodologia, criada por Peter Checkland (1981), proporciona um caminho para questões que ainda não estão bem definidas.

Conforme já foi exposto, o tema de Sustainable Human Resources Management, é recente, e sua aplicação ainda não dispõe de ferramentas capazes de mensurá-la nas organizações. As pesquisas encontradas sobre o assunto pautam-se mais na sua teoria e conceituação, do que em abordagens empíricas.

Como a Gestão Sustentável de Pessoas depende do nível de aderência do comportamento da organização às diretrizes do triple bottom line, de modo que toda organização seja instigada a utilizar esses conceitos em suas atividades diárias, a proposta desta etapa do trabalho foi construir um modelo conceitual integrador dessas questões. $\mathrm{O}$ intuito não foi promover soluções, mas avançar na exploração da temática, com ações que possam ser utilizadas na aplicação da realidade (CHECKLAND, 1981; CEZARINO, 2013; CEZARINO et al., 2006).

A metodologia SSM propõe lidar com situações gerenciais que demandam mudanças para melhorias, e que muitas vezes não são reconhecidas pelos gestores, do que é necessário ser modificado (CHECKLAND, 1981; CEZARINO, 2013). No caso desta pesquisa foi 
analisar a integração da sustentabilidade nas ações de gestão de pessoas, o que demandava um delineamento da GSP.

Para alcançar esse delineamento, os passos da SSM são, segundo Checkland (1981) e Cezarino et al. (2006):

1. Destacar a situação-problema ou algum incômodo.

2. Estruturar a situação-problema e seu processo para produzir quadros ou situações, de modo que não empregue padrões pré-estabelecidos.

3. Utiliza-se a abordagem sistêmica para buscar definições essenciais e enfatizar seus principais elementos: clientes, atores, transformação desejada, visão de mundo organizacional, proprietários e restrições ambientais, ou CATWOE.

4. Nesta etapa, formam-se os modelos conceituais que serão realizações ideais feitas para cada definição essencial.

5. Compara-se o a situação-problema ao quadro elaborado. Nesta etapa a capacidade das organizações absorverem as mudanças é exposta, sendo a base da discussão e debate que leva ao consenso da SSM.

6. Na última etapa, testes são aplicados nas organizações para comprovar se as ações são factíveis ou não. Esta etapa não foi escopo deste trabalho, mas poderá ser uma sugestão de trabalhos futuros.

Essa metodologia e suas respectivas etapas, estão descritas nos resultados e discussão.

\subsection{QUADRO RESUMO}

O Quadro 17 a seguir apresenta uma síntese dos esforços empregados e da coerência metodológica para atingir o objetivo geral estabelecido, que é analisar as iniciativas da gestão sustentável de pessoas no setor bancário brasileiro. 
Quadro 17 - Síntese da pesquisa e proposições

\begin{tabular}{|c|c|c|c|c|}
\hline $\begin{array}{l}\text { OBJETIVOS } \\
\text { ESPECÍFICOS }\end{array}$ & $\begin{array}{l}\text { FONTES DE } \\
\text { INFORMAÇÃO }\end{array}$ & MÉTODO & PROPOSIÇÃO & REFERÊNCIAS \\
\hline $\begin{array}{l}\text { Conhecer as } \\
\text { práticas de gestão } \\
\text { de pessoas } \\
\text { reportadas pelos } \\
\text { bancos; }\end{array}$ & $\begin{array}{l}\text { Relatórios anuais ou } \\
\text { de sustentabilidade }\end{array}$ & $\begin{array}{l}\text { Pesquisa } \\
\text { Documental e } \\
\text { Análise de } \\
\text { Conteúdo. }\end{array}$ & $\begin{array}{l}\text { Os relatórios reportados } \\
\text { pelas organizações do } \\
\text { setor bancário brasileiro } \\
\text { contemplam os tópicos } \\
\text { dos subsistemas de } \\
\text { gestão de pessoas. }\end{array}$ & $\begin{array}{l}\text { EHNERT et al. } \\
(2015) \text {. }\end{array}$ \\
\hline $\begin{array}{l}\text { Levantar os } \\
\text { acórdãos } \\
\text { trabalhistas } \\
\text { movidos pelos } \\
\text { trabalhadores do } \\
\text { setor bancário } \\
\text { finalizadas no ano } \\
\text { de } 2014 \text {. }\end{array}$ & $\begin{array}{l}\text { Acórdãos } \\
\text { trabalhistas }\end{array}$ & $\begin{array}{l}\text { Análise de } \\
\text { Conteúdo e } \\
\text { estatística } \\
\text { descritiva. }\end{array}$ & $\begin{array}{l}\text { O não equilíbrio entre a } \\
\text { vida profissional e a } \\
\text { vida pessoal podem } \\
\text { resultar em queixas } \\
\text { trabalhistas. }\end{array}$ & $\begin{array}{l}\text { GOLIK (2013); } \\
\text { SOUZA et al. } \\
(2015) ; \text { APPEL e } \\
\text { BITENCOURT } \\
(2008) .\end{array}$ \\
\hline $\begin{array}{l}\text { Identificar a visão } \\
\text { do Sindicato dos } \\
\text { Bancários e } \\
\text { Financiários de São } \\
\text { Paulo, Osasco e } \\
\text { Região e da } \\
\text { Federação } \\
\text { Brasileira de } \\
\text { Bancos quanto às } \\
\text { práticas de gestão } \\
\text { de pessoas } \\
\text { praticadas pelos } \\
\text { bancos. }\end{array}$ & $\begin{array}{l}\text { Entrevistas } \\
\text { semiestruturadas }\end{array}$ & $\begin{array}{l}\text { Análise de } \\
\text { Conteúdo }\end{array}$ & $\begin{array}{l}\text { O setor bancário } \\
\text { brasileiro tem integrado } \\
\text { a sustentabilidade em } \\
\text { suas ações de gestão de } \\
\text { pessoas. }\end{array}$ & $\begin{array}{l}\text { EWEJE (2011); } \\
\text { EHNERT et al. } \\
\text { (2015); van } \\
\text { MARREWIJK } \\
(2003) \text {. }\end{array}$ \\
\hline
\end{tabular}

Fonte: Elaborado pela autora.

\section{RESULTADOS E DISCUSSÃO}

Este capítulo teve o objetivo de realizar a discussão e análise dos dados encontrados nos cinco bancos brasileiros selecionados. Na primeira parte encontra-se um breve histórico dos bancos: Banco do Brasil, Banco Itaú Unibanco, Caixa Econômica Federal, Banco Bradesco e Banco Santander.

Após essa contextualização, os subsistemas de gestão de pessoas foram divididos nos seguintes tópicos:

1. Recrutamento e Seleção;

2. Treinamento e Desenvolvimento;

3. Gestão de Desempenho e Avaliação e Sistema de Pagamento;

4. Saúde, Segurança e Qualidade de Vida no Trabalho;

5. Desafios e Metas para os próximos anos. 
Para cada um dos tópicos, as ações de cada banco foram descritas e obtidas nos relatórios anuais ou de sustentabilidade, e confrontadas com o que foi encontrado na literatura e com as informações obtidas nas entrevistas com o Sindicato dos Bancários e da Febraban.

A parte subsequente condiz com o desenvolvimento da metodologia sistêmica para a Gestão Sustentável de Pessoas, com a elaboração do framework.

\subsection{BREVE HISTÓRICO DOS BANCOS ANALISADOS}

\subsubsection{BANCO DO BRASIL}

O Banco do Brasil (BB) é o mais antigo do mercado financeiro brasileiro. Com a vinda da família real para cá, foi determinada sua criação. Em 1817 foi realizada a primeira oferta pública de ações de mercado de capitais brasileiro (BANCO DO BRASIL, 2014).

Em 1967, ele passa a dedicar suas energias ao mercado internacional e em 1968 começa também sua expansão geográfica no território brasileiro, sendo a milésima agência inaugurada em 1976. A criação da Fundação Banco do Brasil e a atuação em todos os segmentos do mercado financeiro, tornou o BB uma instituição financeira completa (BANCO DO BRASIL, 2014).

Em 2006, foi listado na BM\&FBovespa, na qual se reúnem as empresas com as melhores práticas de governança corporativa. Em 2014, com os ativos alcançando $\mathrm{R} \$ 1,3$ trilhão, se firmou como maior instituição financeira da América Latina. Atualmente possui 19.143 pontos de atendimento e está presente em 99, 9\% dos municípios brasileiros. No exterior já alcança a marca de 49 pontos próprios, localizado em 24 países e mais de 1,2 mil bancos conveniados que atuam como correspondentes em 134 países, sendo o maior banco brasileiro com rede própria de atendimento no exterior.

\subsubsection{BANCO ITAÚ UNIBANCO}

Diante de uma perspectiva histórica, as trajetórias do Itaú e do Unibanco se convergem. A fusão dos dois ocorreu aos 63 anos de Itaú e 84 anos de Unibanco, no ano de 2008 (ITAUUNIBANCO, 2014).

As duas instituições fizeram ao longo dos anos parte da onda de fusões e aquisições. Na década de 90, após o período hiperflacionário ser vencido, um novo ciclo ocorreu, e as duas instituições tiveram como estratégia absorver grandes concorrentes que não conseguiram superar a transição (ITAUUNIBANCO, 2014). 
Em 2008, diante da crise financeira, o Banco Central aprovou a associação entre Itaú e Unibanco, sendo em 2009 a unificação das marcas. Hoje o Itaú Unibanco Holding S. A. atua além do Brasil, em mais de 20 países (ITAUUNIBANCO, 2014).

\subsubsection{CAIXA ECONÔMICA FEDERAL}

Em 1861, a Caixa Econômica da Corte foi fundada por Dom Pedro II, e desde então vem acompanhando a história brasileira. Em 1931, inaugurou as operações de empréstimo por consignação para pessoas físicas, e três anos depois passou a ser exclusivo nos empréstimos sob penhor (CAIXA, 2014).

Em 1986, o Banco Nacional de Habitação (BNH) foi incorporado pela Caixa, tornando-a a maior agente financiadora de casa própria e de desenvolvimento urbano, especialmente em saneamento básico. No mesmo ano tornou-se administradora do Fundo de Garantia do Tempo de Serviço (FGTS), centralizando todas as contas vinculadas a ele no ano de 1990 (CAIXA, 2014).

Além do FGTS, atende também poupanças, Programa de Integração Social (PIS), Seguro-Desemprego, entre outros, e a partir de 1961 passou a deter o monopólio das Loterias Federais. Hoje apresenta mais de 36,2 mil unidades, alcançando mais de 5 mil municípios, além dos 29 mil entre correspondentes bancários, lotéricas e postos CAIXA AQUI (CAIXA, 2014).

\subsubsection{BANCO BRADESCO}

Fundado em Marília, em 1943, foi o primeiro banco a colocar seus gerentes para atender o público. Com uma visão inovadora de ser democrático, atendia os imigrantes, lavradores e pequenos comerciantes (BRADESCO, 2014).

Em 1956 foi criada a Fundação Bradesco, responsável pela formação de milhares de alunos nas últimas 5 décadas. Entre a década de 60 e 70 o banco passou por várias inovações, lançando o primeiro cartão de crédito do Brasil, a microfilmagem de cheques, o débito automático de contas de água, luz e telefone para empresas, a retirada de dinheiro a qualquer hora do dia com o SOS Bradesco, entre outros (BRADESCO, 2014).

Em 1980, o Bradesco entrou no mercado de Previdência Privada, de Títulos de capitalização e Saúde, e criou suas primeiras representações internacionais em Londres, Nova Iorque e Caribe. Continuou sua expansão em inovações, adquirindo os maiores computadores do mundo e lançando o primeiro cartão magnético do país. Em 1990 foi o banco com o $1^{\circ}$ Internet Banking do Brasil e $5^{\circ}$ do mundo (BRADESCO, 2014). 
$\mathrm{Na}$ década de 90, o banco ficou entre os 3 finalistas do prêmio de soluções de TI para o bem da humanidade pelo acesso à internet para pessoas com deficiência visual e tornou-se o único case da América Latina citado no livro de Bill Gates, "A Empresa na Velocidade do Pensamento". Em 2000, o Bradesco aderiu ao Pacto Global e os Princípios do Equador, e lançado o Banco do Planeta, que definiu um novo posicionamento frente as ações socioambientais da organização (BRADESCO, 2014).

Além dessas aderências, o banco teve suas ações integrando o ISE - Índice de Sustentabilidade Empresarial, da Bovespa, e o Índice Dow Jones de Sustentabilidade. Em 2003, a edição do Dia Nacional de Ação Voluntária passou a ser uma nova tradição. Em 2006, junto à Fundação Bradesco, o projeto Educa+Ação foi lançado a fim de integrar a iniciativa privada e o setor público municipal e em parceria com o Governo do Amazonas, se tornou cofundador da Fundação Amazonas Sustentável, entidade sem fins lucrativos que preserva a floresta e contribui para o desenvolvimento sustentável (BRADESCO, 2014).

Em 2010, o Centro de Desenvolvimento Esportivo da ADC Bradesco Esportes e Educação foi inaugurado e o complexo recebeu selo verde, por ser uma construção sustentável pela ONG U.S. Green Building Council. Hoje, com 70 anos de história, conta com mais de 44 mil pontos de atendimento, e 55 milhões de clientes (BRADESCO, 2014).

\subsubsection{BANCO SANTANDER}

O Banco Santander entrou no território brasileiro por meio de um acordo operacional com o Banco Intercontinental do Brasil S. A. em 1957. A partir de 1997 passou a fazer aquisições como: Banco Geral do Comércio S.A., Banco Noroeste S.A., Banco Meridional S.A., aumentando consideravelmente sua presença no país (SANTANDER, 2014).

Em 2000 fez a aquisição do Banespa, que era detido pelo Estado de São Paulo, levando o Grupo Santander ao título de maior grupo financeiro do país. No final de 2007 um consórcio composto pelo Santander Espanha, The Royal Bank of Scotland Group PLC, Fortis SA/NV e Fortis N.V., adquiriu 96,95\% do capital do ABN AMRO, então controlador do Banco Real. Após a aprovação pelo CADE (Conselho Administrativo de Defesa Econômica), as pessoas jurídicas brasileiras do ABN AMRO foram adquiridas pelo consórcio. Diante de um acordo entre as partes o Santander passou a ter direito às atividades de administração de ativos da ABN AMRO (SANTANDER, 2014).

Em 2008 assumiu também o controle acionário direto do Banco Real, passando meses depois este ser uma subsidiária integral do Santander Brasil. Com essa aquisição, Santander 
passou a ser o terceiro maior banco privado do Brasil em termos de ativos (SANTANDER, 2014).

\subsection{RECRUTAMENTO E SELEÇÃO}

O processo de Recrutamento e Seleção (R\&S) é responsável por almejar os melhores profissionais do mercado que consigam atender aos requisitos exigidos ao perfil da vaga ofertada (LIMONGI-FRANÇA e ARELLANO, 2002).

\subsubsection{BANCO DO BRASIL}

Dentro dos quesitos de empregabilidade, o Banco do Brasil conta com cerca de 110 mil colaboradores. Sua taxa de contratação de novos funcionários é calculada em relação ao seu ano anterior. Então, em 2013 ela foi de $-1,7 \%$.

Sua rotatividade é apresentada em categorias na Tabela 7.

Tabela 7 - Rotatividade por Faixa Etária do Banco do Brasil

\begin{tabular}{lr}
\hline \multicolumn{2}{l}{ Rotatividade por faixa etária } \\
\hline Até 25 Anos & 5,92 \\
De 26 a 35 Anos & 3,08 \\
De 36 a 45 Anos & 1,61 \\
Acima de 45 Anos & 9,55 \\
\hline
\end{tabular}

Analisando os dados da Tabela 4, nota-se que os colaboradores acima de 45 anos são os que apresentam os maiores índices de rotatividade da organização. Segundo a visão do Sindicato, os jovens aguentam mais as jornadas de trabalho e as metas impostas, já os funcionários mais antigos acabam sofrendo de doenças ocupacionais e algumas doenças muito graves, que fazem com que eles abdiquem de seus trabalhos para se tratarem.

Além disso, há a questão do incentivo à aposentadoria àqueles que completam 50 anos de idade, o que faz com que essa faixa etária represente esse maior índice se comparado aos outros níveis. Um outro aspecto que justifica esse índice podem ser as promoções salariais e acúmulo de benefícios que os funcionários mais antigos possuem. $\mathrm{O}$ incentivo à aposentadoria nesses casos pode ser uma estratégia de redução de gastos com a folha de pagamento, já que novos funcionários não terão os mesmos benefícios e salários.

Comparada à questão do gênero, a rotatividade não apresenta muita diferença, sendo para o sexo masculino a taxa de $5,03 \%$ e para o sexo feminino $4,56 \%$. Já as taxas por região 
geográfica brasileira apresentam índices parecidos, sendo a região Sul com um percentual levemente maior que as outras regiões, como pode ser observado na Tabela 8 a seguir:

Tabela 8 - Rotatividade por região geográfica do Banco do Brasil

\begin{tabular}{lc}
\hline \multicolumn{2}{l}{ Rotatividade por região geográfica } \\
\hline Norte & 5,07 \\
Nordeste & 5,51 \\
Sudeste & 4,8 \\
Centro-Oeste & 4,04 \\
Sul & 6,35 \\
\hline
\end{tabular}

Outro aspecto trazido no Relatório Anual do Banco do Brasil é a questão da diversidade. O Banco aderiu ao programa da Febraban de Valorização da Diversidade, que incentiva o recrutamento e seleção pautados na diversidade, bem como outras áreas de gestão de pessoas que devem seguir esses princípios.

Dos 110 mil colaboradores que o Banco do Brasil apresenta, cerca de 24\% são negros, pardos ou índios, 7\% apenas ocupam cargos de chefia, e nem 1\% representa o número de portadores de deficiência ou necessidades especiais. A Tabela 9 a seguir apresenta os números totais em 2013.

Tabela 9 - Diversidade no Banco do Brasil

\begin{tabular}{lc}
\hline \multicolumn{3}{c}{ DIVERSIDADE NO BANCO DO BRASIL } \\
\hline Número de Negros(as), Pardos(as) ou Índios(as) que Trabalham na Empresa & 26.851 \\
Número de Negros, Pardos ou Índios que Ocupam Cargos de Chefia & 7.860 \\
Número de Portadores (as) de Deficiência ou Necessidades Especiais & 1.038 \\
\hline
\end{tabular}

A Febraban informou que os bancos tem despendido esforços na questão da equidade de oportunidades, e que mesmo os índices ainda sendo baixos de negros, pardos, índios e portadores de necessidades especiais, do Censo da Diversidade de 2008 para 2014 já houve uma melhoria. Em 2008 os índices eram 19\% de negros e 16,7\% de pardos, já em 2014, o quadro representativo passou para $24,7 \%$ de negros e $21,3 \%$ de pardos. Deste modo, o Banco do Brasil está na média do índice apresentado em 2014 pelo Censo da Diversidade.

Quanto à presença de Pessoas com Deficiência no quadro de funcionários, o Banco do Brasil ainda está aquém ao que é exigido por lei, apresentando menos de $1 \%$ dos funcionários nessas condições. De acordo com a Febraban, por ser uma organização que atrai talentos mediante concurso, o cumprimento da lei nesse aspecto fica baseado no interesse dos candidatos com necessidades especiais se inscreverem no processo de seleção. Apesar das vagas destinadas à eles, o banco ainda enfrenta dificuldades para preencher essa lacuna. 
As etapas dos concursos públicos do Banco do Brasil contam com Prova Objetiva, de caráter eliminatório e classificatório e Prova Discursiva-Redação de caráter eliminatório. Qualquer pessoa com certificado de conclusão de Ensino Médio e acima de 18 anos pode se candidatar ao processo seletivo para preenchimento do cargo de escriturário.

Dentro do âmbito de comunicação da marca e de suas ações de sustentabilidade organizacional, trazidos por Renwick et al. (2013), o BB acredita que a geração de resultados sustentáveis está ligado ao retorno dos acionistas e dele como atuante no desenvolvimento sustável do país. Para o público interno, ou seja, os colaboradores, a questão da comunicação da marca e das ações de sustentabilidade, não foram encontradas informações relatadas pelo Banco do Brasil em seu relatório anual.

Assim, seus negócios sociais estão alinhados às políticas públicas, como no Programa Minha Casa Minha Vida, Fundo de Financiamento ao Estudante do Ensino Superior (FIES), Programa Nacional de Fortalecimento da Agricultura Familiar, entre outros.

Através da sua capilaridade, o BB pode influenciar positivamente a sociedade em práticas mais sustentáveis, principalmente nesses programas que abrangem grande número da população brasileira.

\subsubsection{BANCO ITAÚ UNIBANCO}

Dentro dos quesitos de empregabilidade o Banco Itaú-Unibanco conta com cerca de 95 mil colaboradores. Deste número, são mais de 87 mil no Brasil, 1.194 na Credicard, e quase 7 mil no exterior. Sua taxa geral de contratação de novos funcionários é calculada em relação ao seu ano anterior, e em 2013 ela foi de $-1,3 \%$.

As taxas de contratação por faixa etária, gênero e região geográfica podem ser analisadas na Tabela 10 a seguir.

Tabela 10 - Taxa de contratação por faixa etária, gênero e região do Banco Itaú-Unibanco

\begin{tabular}{lcccccc}
\hline \multicolumn{7}{c}{ Taxa de contratação por faixa etária, gênero e região } \\
\hline REGIÃO & \multicolumn{5}{c}{ MULHERES } & \multicolumn{3}{c}{ HOMENS } \\
\hline FAIXA & Abaixo de 30 & Entre 30 e & Acima de & Abaixo de 30 & Entre 30 e & Acima de \\
ETÁRIA & anos & 50 anos & 50 anos & anos & 50 anos & 50 anos \\
SUL & 25,74 & 2,45 & 0 & 32,42 & 2,88 & 0 \\
SUDESTE & 19,23 & 1,76 & 0,1 & 17,82 & 1,92 & 0,15 \\
CENTRO- & 17,96 & 2,32 & 0 & 21,53 & 2,98 & 0,61 \\
OESTE & 14,80 & 1,52 & 0 & 17,61 & 2,35 & 0 \\
NORDESTE & 21,76 & 0,85 & 0 & 18,53 & 2,3 & - \\
NORTE & 19,55 & 1,82 & 0,8 & 19,14 & 2,07 & 0,15 \\
TOTAL & & & & & \\
\hline
\end{tabular}


Independentemente do gênero, as novas contratações ficaram pautadas na maior parte na faixa etária abaixo de 30 anos. Esse fato condiz com Silva e Navarro (2012), que afirmam que a instituição bancária passou a contratar jovens em início de carreira, com pouca experiência profissional, por ser uma atividade com remuneração um pouco mais elevada que outros setores, em cidades principalmente onde a oferta de empregos não é muito ampla, passando a ser uma oferta atrativa.

Além disso, a Febraban afirmou que a rotatividade costuma ser maior nos primeiros três anos de emprego entre os jovens que estão estudando, pois há possibilidade de indefinição da carreira e suas compatibilidades entre aspirações universitárias e carreira no setor bancário.

Em termos de rotatividade, o Itaú-Unibanco também segue as sugestões da diretriz G4 do GRI, na qual há uma comparação entre gêneros, faixa etária e região geográfica de atuação. A rotatividade em geral foi de $11,10 \%$. Os números podem ser observados na Tabela 11 a seguir.

Tabela 11 - Rotatividade por faixa etária, gênero e região do Banco Itaú-Unibanco

\begin{tabular}{lcccccc}
\hline \multicolumn{7}{c}{ Rotatividade por faixa etária, gênero e região } \\
\hline REGIÃO & \multicolumn{7}{c}{ MULHERES } & \multicolumn{3}{c}{ HOMENS } \\
\hline FAIXA & Abaixo de 30 & Entre 30 e & Acima de & Abaixo de 30 & Entre 30 e & Acima de \\
ETÁRIA & anos & 50 anos & 50 anos & anos & 50 anos & 50 anos \\
SUL & 7,60 & 6,86 & 11,27 & 6,34 & 8,23 & 12,39 \\
SUDESTE & 7,21 & 7,26 & 16,70 & 7,87 & 7,83 & 14,76 \\
CENTRO- & 6,62 & 7,85 & 14,29 & 6,21 & 8,17 & 11,52 \\
OESTE & 7,15 & 6,21 & 15,00 & 7,69 & 6,69 & 7,80 \\
NORDESTE & 4,68 & 9,97 & 33,33 & 10,34 & 8,76 & 0 \\
NORTE & 7,16 & 7,22 & 15,88 & 7,72 & 7,82 & 13,94 \\
TOTAL & & & & & \\
\hline
\end{tabular}

Pode-se observar que dentro das faixas etárias, o turnover é maior acima de 50 anos, para os dois gêneros, em todas as regiões. De acordo com a Febraban este índice pode ser reflexo da aposentadoria, já que existem planos de previdência privada, tanto nos bancos públicos quanto os privados.

Ainda considera-se que a longa permanência dos profissionais permite evolução na carreira e vantagens na aposentadoria, e ao atingir o tempo necessário de contribuição e um volume expressivo de valores nos fundos de aposentadoria, é comum que os colaboradores saiam da organização.

O índice de maior rotatividade é para o gênero feminino, acima de 50 anos, na região Norte, com 33,33\%, um valor bem acima dos outros índices. A menor rotatividade está nas mulheres da região norte abaixo de 30 anos, faixa etária esta que em geral apresenta índices 
mais baixos em todas as regiões. Este dado pode ser reflexo do número de contratações nesta faixa etária, mas uma análise mais aprofundada nesse aspecto pode responder melhor a causa desse índice.

Outro aspecto importante para a organização é o respeito às diversidades. O Banco Itaú-Unibanco aderiu ao programa da Febraban de Valorização da Diversidade, que incentiva o recrutamento e seleção pautados na diversidade, bem como outras áreas de gestão de pessoas que devem seguir esses princípios.

A Tabela 12 a seguir mostra os números totais de mulheres, afrodescendentes, deficientes e jovens aprendizes no ano de 2013, além de sua respectiva porcentagem em relação ao total de colaboradores.

Tabela 12 - Colaboradores Itaú-Unibanco

\begin{tabular}{lcc}
\hline & Total & \% em relação aos colaboradores \\
\hline Mulheres & 49.770 & 59,3 \\
Afrodescendentes & 15.804 & 18,8 \\
Deficientes & 4.197 & 5 \\
Jovem Aprendiz & 1.792 & 2,1 \\
Total: Colaboradores & $83.903^{2}$ & 100 \\
\hline
\end{tabular}

Apesar da representatividade de mulheres ser de quase $60 \%$ dos colaboradores, ainda há pontos negativos, como uma desigualdade nos números de afrodescendentes na organização, visto que representam cerca de $19 \%$ do total dos colaboradores. Pelo Censo da Diversidade de 2014, o número médio de afrodescendentes é de $24 \%$, ou seja, o Itaú fícou um pouco abaixo da média dos bancos nesse quesito.

Para a empresa Itaú como um todo, o número de deficientes está de acordo com a Lei 7.853, de 24 de Outubro de 1989: acima de 1.001 colaboradores e com seus cargos preenchidos acima de 5\% com beneficiários reabilitados ou pessoas portadoras de deficiência.

Para recrutar e selecionar seus colaboradores, o Banco Itaú-Unibanco apresenta algumas características comuns às corporações privadas.

Os candidatos podem enviar seus currículos através do portal eletrônico. Para trainees, é divulgado que o banco busca estudantes do último ano de graduação ou recém-formados nos últimos 12 meses nos cursos de Administração de Empresas, Ciências Contábeis, Direito, Economia, Engenharias, Estatística, Física e Matemática, com nível avançado em inglês e raciocínio lógico-matemático.

As etapas são: i) inscrição no processo seletivo; ii) provas de inglês, raciocínio lógico e conhecimentos sobre cultura, economia e política brasileira; iii) business case, para avaliar a capacidade de resolução de problemas e o alinhamento do candidato aos valores e atitudes

\footnotetext{
${ }^{2}$ Esse número considera apenas informações sobre as empresas administradas pela Área de Pessoas.
} 
prezados pelo banco; iv) super saturday, onde os candidatos podem conversar com os executivos das áreas. Já o processo seletivo para estagiários conta com a prova presencial e entrevista com a consultoria e depois com uma entrevista individual com o gestor da área.

No website do Itaú Unibanco (http://eb.vagas.com.br/itauunibanco), é possível verificar as vagas ofertadas por área/programa e por região. Para cada vaga há descrição das funções a serem realizadas, o perfil desejado entre as competências técnicas, experiências e o comportamento esperado (referente aos CHAs - Conhecimentos, Habilidades e Atitudes).

Para encontrar informações sobre a preferência por candidatos que utilizam as questões ambientais, sociais e econômicas para definirem o local onde ensejam trabalhar, bem como se há utilização desses aspectos nas provas, business case e nas entrevistas, uma metodologia com dados primários seria necessária.

O Banco Itaú-Unibanco divulga que tem criado esforços contínuos para melhorar seu processo de diálogo com os stakeholders, compreendendo as expectativas, tendências, e priorizando os problemas para apresentar soluções. Em 2013, a comunicação da marca e das ações de sustentabilidade concentrou-se na educação financeira.

Para o público interno, ações como a campanha de performance sustentável, treinamento de sustentabilidade, ombudsman ${ }^{3}$ e outras pesquisas de satisfação de colaboradores, tiveram intuito de buscar educar, envolver e compreender as suas demandas. Já para o público externo, há a forte presença nas redes sociais e participação em grupos de discussão sobre sustentabilidade com os clientes. Essas ações visam a comunicação da marca e de suas ações de sustentabilidade organizacional, trazidos por Renwick et al. (2013).

Quanto à utilização de empresas parceiras de $R \& S$ conscientes e atuantes na sustentabilidade organizacional, uma análise mais aprofundada na empresa Vagas.com, responsável pelo processo seletivo deste banco, é necessária.

\subsubsection{CAIXA ECONÔMICA FEDERAL}

Nos quesitos de empregabilidade, a Caixa Econômica Federal (CEF) conta com mais de 160 mil funcionários. No ano de 2013 houve um aumento na admissão dos funcionários, num total de 7.978 , sendo 3.654 mulheres e 4.324 homens.

A rotatividade no mesmo ano foi de $5,43 \%$, e a taxa de desligamento de funcionários de 2,74\%. As diretrizes sugeridas pelo GRI dos dados serem classificados de acordo com gênero, região geográfica e por faixa etária não foram seguidas pela CEF.

\footnotetext{
3 Ombudsman é um profissional contratado com a função de receber críticas, sugestões e reclamações de usuários e consumidores, devendo agir com imparcialidade, mediando conflitos.
} 
A taxa de retenção após licença maternidade alcança 99,36\% dos casos. Em relação a diversidade, a Caixa tem o Programa CAIXA de Diversidade, que se divide em quatro eixos: equidade de gênero, igualdade racial, orientação sexual e pessoas com deficiência. A prioridade é combater todas as formas de discriminação e estimular práticas de gestão que respeitem a diversidade.

Com relação aos indicadores internos de diversidade, a presença de mulheres, negros e pessoas com deficiência são retratados na Tabela 13 a seguir.

Tabela 13 - Quadro de Pessoal da CEF referente à diversidade.

\begin{tabular}{|c|c|c|c|c|c|c|}
\hline Empregados & $\begin{array}{c}\text { Mulheres } \\
\text { negras } \\
\text { (pardas e } \\
\text { pretas) }\end{array}$ & $\begin{array}{c}\text { Homens } \\
\text { Negros } \\
\text { (pardos e } \\
\text { pretos) }\end{array}$ & $\begin{array}{l}\text { Total de } \\
\text { negros } \\
\text { (pardos e } \\
\text { pretos) }\end{array}$ & Mulheres & $\begin{array}{l}\text { Pessoa com } \\
\text { deficiência }\end{array}$ & $\begin{array}{c}\text { Pessoas } \\
\text { acima de } \\
45 \text { anos }\end{array}$ \\
\hline $\begin{array}{l}\text { Em relação ao total } \\
\text { Gerentes em }\end{array}$ & 8,95 & 13,24 & 22,19 & 45,23 & 1,20 & 36,91 \\
\hline $\begin{array}{l}\text { relação ao total de } \\
\text { funções gerenciais }\end{array}$ & 6,89 & 12,81 & 19,70 & 40,51 & 0,57 & 41,57 \\
\hline $\begin{array}{l}\text { Dirigentes em } \\
\text { relação ao total de } \\
\text { cargos de } \\
\text { dirigentes. }\end{array}$ & 0 & 13,33 & 13,33 & 10 & 0 & 60 \\
\hline
\end{tabular}

Dos bancos analisados neste trabalho, a CEF é a que apresenta maior número de funcionários. Destes, o número representado por mulheres e homens afrodescendentes ainda é baixo, com $22 \%$ no total. Utilizando a média do Censo da Diversidade de 2014, em que os afrodescendentes representam $24 \%$ do setor bancário, a CEF está próximo da média, principalmente levando em consideração que seus processos seletivos são por meio de concursos, e dependem da intenção dos candidatos de ingressarem à organização.

A Febraban alega que aos poucos os bancos tem conseguido investir para que o aumento da representatividade dos afrodescendentes na composição do quadro de funcionários ocorra.

$\mathrm{O}$ mesmo esforço tem sido para a equidade de gênero no setor bancário. A CEF apresenta $45 \%$ do seu quadro formado pelo gênero feminino, próximo ao levantado pelo Censo da Diversidade, que em 2014 mostrou que 51,7\% dos funcionários são do sexo masculino e $48,3 \%$ são do sexo feminino.

Outro número que se evidencia é o da representação de 1,2\% dos colaboradores portadores de necessidades especiais, já que por lei essa taxa deveria ser maior que $5 \%$ para organizações com mais de mil funcionários. A Caixa alega que apesar de reservar 5\% das 
vagas abertas em concurso público, esse percentual fica condicionado ao número de candidatos aprovados nessa categoria.

A CEF, assim como o Banco do Brasil, é uma instituição pública, que seleciona seus funcionários por meio de concursos. As informações a respeito dos editais de concurso estão no website da Caixa e da organizadora do concurso (CESPE/UnB), para a carreira administrativa, cargo de Técnico Bancário Novo e para carreira profissional, além da presença de informações técnicas do processo. Nos editais as etapas do processo seletivo são descritas, e assim como o Banco do Brasil, existem provas objetivas e discursivas, abrangendo conhecimentos básicos e específicos do setor.

Ademais dos concursos, a CEF conta com outros programas de recrutamento e seleção: Programas Adolescente e Jovens Aprendiz e o Programa Estágio. O primeiro proporciona a oportunidade de primeiro emprego aos jovens estudantes brasileiros, onde além de ser promovida a inclusão social, tem o intuito de elevar o nível de escolaridade desses jovens, que são normalmente oriundos de famílias com renda familiar per capita igual ou inferior a 50\% do salário mínimo nacional.

Para participar desse programa, o aprendiz tem que estar matriculado na escola e apresentar comprovante de frequência. A seleção ocorre por meio de entidades conveniadas, que contratam, capacitam e acompanham esses jovens durante suas estadias.

O segundo programa citado é destinado a estudantes de nível médio, médio técnico e superior. Em 2013 foram selecionados mais de 12 mil estagiários. O recrutamento e seleção desses estagiários também não foi descrito no relatório anual da CEF.

Dentro do âmbito de comunicação da marca e de suas ações de sustentabilidade organizacional, trazidos por Renwick et al. (2013), e da escolha de empresas parceiras de recrutamento e seleção conscientes e atuantes da sustentabilidade organizacional, não foram encontradas informações que descrevessem essas iniciativas pela CEF.

\subsubsection{BANCO BRADESCO}

O Banco Bradesco conta cerca de mais de 100 mil funcionários. A distribuição do quadro de funcionários está classificada em seu relatório anual quanto à região geográfica, gênero e faixa etária. A Tabela 14 a seguir mostra os números totais e as porcentagens relativas ao total de cada categoria. 
Tabela 14 - Distribuição dos funcionários - Bradesco

\begin{tabular}{|c|c|c|c|c|c|}
\hline REGIÃO & Homens & Mulheres & $\begin{array}{l}\text { Abaixo de } 30 \\
\text { anos }\end{array}$ & $\begin{array}{l}\text { Entre } 30 \text { e } 50 \\
\text { anos }\end{array}$ & $\begin{array}{l}\text { Acima de } 50 \\
\text { anos }\end{array}$ \\
\hline SUL & $\begin{array}{l}5.098 \\
(53,78 \%)\end{array}$ & $\begin{array}{l}4.381 \\
(46,22 \%)\end{array}$ & $5.339(56,32 \%)$ & $3.793(40,01 \%)$ & $347(3,66 \%)$ \\
\hline SUDESTE & $\begin{array}{l}33.537 \\
(48,34 \%)\end{array}$ & $\begin{array}{l}35.836 \\
(51,66 \%)\end{array}$ & $34.309(49,46 \%)$ & $31.015(44,71 \%)$ & $4.049(5,84 \%)$ \\
\hline $\begin{array}{l}\text { CENTRO- } \\
\text { OESTE }\end{array}$ & $\begin{array}{l}2.820 \\
(58,71 \%)\end{array}$ & $\begin{array}{l}1.983 \\
(41,29 \%)\end{array}$ & $2.906(60,50 \%)$ & $1.782(37,10 \%)$ & $115(2,39 \%)$ \\
\hline NORDESTE & $\begin{array}{l}7.009 \\
(54,11 \%)\end{array}$ & $\begin{array}{l}5.944 \\
(45,89 \%)\end{array}$ & $6.489(50,10 \%)$ & $4.676(36,10 \%)$ & $1.788(13,80 \%)$ \\
\hline NORTE & $\begin{array}{l}2.085 \\
(57,87 \%)\end{array}$ & $\begin{array}{l}1.518 \\
(42,13 \%)\end{array}$ & $2.506(69,55 \%)$ & $956(26,53 \%)$ & $141(3,91 \%)$ \\
\hline
\end{tabular}

Em 2013, foram admitidos 7.681 funcionários, e a rotatividade foi em torno de 10,5\%. Por região geográfica, a rotatividade pode ser analisada na Tabela 15 a seguir, sendo o menor índice na região Nordeste.

Tabela 15 - Rotatividade por região geográfica - Bradesco

\begin{tabular}{lc}
\hline ROTATIVIDADE POR REGIÃO GEOGRÁFICA \\
\hline Sul & 10,25 \\
Sudeste & 10,88 \\
Centro-Oeste & 11,38 \\
Nordeste & 7,71 \\
Norte & 11,62 \\
\hline
\end{tabular}

Referente à questão da diversidade, o Bradesco conta com os seguintes números de grupos minoritários:

Tabela 16 - Diversidade no Banco do Brasil

\begin{tabular}{lc}
\hline \multicolumn{2}{c}{ DIVERSIDADE NO BANCO DO BRASIL } \\
\hline Mulheres & 49.781 \\
Negros (pardos + pretos) & 23.941 \\
Funcionários com idade acima de 45 anos & 15.047 \\
Pessoas com deficiência & 2.185 \\
\hline
\end{tabular}


Assim como nos outros bancos já analisados, o Bradesco está próximo de uma equidade de gênero em seu quadro de funcionários, apresenta $25 \%$ de afrodescendentes dentre seus funcionários (acima da média do Censo da Diversidade 2014) e não atinge o exigido por lei de acima de 5\% das vagas serem preenchidas por pessoas com deficiência, possuindo cerca de $2 \%$ do seu quadro.

As informações sobre o processo de recrutamento e seleção dos candidatos fica pautado no cadastro do currículo online, e quando as vagas surgirem, o aspirante à vaga é contatado para ser informado das próximas fases do processo.

Por ser um banco com diversas iniciativas ao longo de sua história pautado na sustentabilidade, uma gestão sustentável de pessoas poderia propor o R\&S com um perfil delimitado nas questões sociais, ambientais e econômicas, visando candidatos que se identifique com essas questões organizacionais. Neste tipo de gestão, o processo seletivo poderia contar com testes online, dinâmicas, utilização de cases pautados no TBL.

No que se refere à comunicação da marca em sustentabilidade (RENWICK et al., 2013), o Bradesco afirma que as discussões sobre a nova abordagem avançaram em 2013. Diante de stakeholders cada vez mais críticos e reguladores mais ativos, e as novas iniciativas quanto à isso seriam implementadas nos próximos anos. Como o relatório analisado neste trabalho é o disponível na base de dados do GRI e de 2013, não se tem mais informações a respeito desse aspecto.

Nesse aspecto, a visão do Sindicato é de que mesmo havendo planos de ações em termos de melhorias contínuas, ou cartas de intenção, cartilhas, treinamentos, sem realmente acontecerem as modificações, a estratégia do banco não fica pautada nas pessoas, mas somente no lucro, comprometendo a sustentabilidade pregada por eles.

Quanto à escolha de parcerias de empresas de Recrutamento e Seleção conscientes e atuantes da sustentabilidade organizacional, como o processo seletivo fica pautado no envio online de currículo, e as etapas são posteriormente comunicadas aos candidatos, não foram encontradas informações sobre parcerias para essa área.

\subsubsection{BANCO SANTANDER}

O Grupo Santander, de origem espanhola, tem sua atuação em nível global, presente na Europa, América Latina e do Norte, e África. No Brasil, conta com quase 50 mil funcionários. A taxa de contratação de novos funcionários, de demissão e rotatividade estão separadas por gênero, região e faixa etária. Nas Tabelas 17, 18 e 19 a seguir os números são apresentados. 
Tabela 17 - Número de funcionários do Santander discriminados por gênero

\begin{tabular}{lllll}
\hline \multicolumn{5}{c}{ TAXAS POR GÊNERO } \\
\hline & ADMITIDOS & \%ADMITIDOS & DEMITIDOS & TURNOVER \\
Homens & 1.422 & 43,70 & 3.303 & 15,70 \\
Mulheres & 1.832 & 56,30 & 4.338 & 14,10 \\
Total & 3.254 & 100 & 7.641 & 14,75 \\
\hline
\end{tabular}

Nota-se que o número de colaboradores demitidos no banco foi quase o dobro de admitidos, independentemente do gênero. Porém, em termos de rotatividade, os índices relativos à gênero foram bem próximos.

Das regiões geográficas brasileira, o menor índice de rotatividade encontrado foi na região Sudeste e Nordeste. A tabela a seguir apresenta uma melhor visualização dos dados.

Tabela 18 - Número de funcionários do Santander discriminados por Região Geográfica

\begin{tabular}{lcccc}
\hline \multicolumn{5}{c}{ TAXAS POR REGIÃO GEOGRÁFICA } \\
\hline & ADMITIDOS & \%ADMITIDOS & DEMITIDOS & TURNOVER \\
Norte & 72 & 2,21 & 137 & 20,21 \\
Nordeste & 224 & 6,88 & 455 & 12,50 \\
Centro-Oeste & 168 & 5,16 & 303 & 16,91 \\
Sul & 268 & 8,24 & 938 & 18,12 \\
Sudeste & 2.522 & 77,50 & 5.808 & 14,33 \\
Total & 3.254 & 100 & 7.641 & 14,75 \\
\hline
\end{tabular}

Tabela 19 - Número de funcionários do Santander discriminados por faixa etária

\begin{tabular}{lcccc}
\hline \multicolumn{5}{c}{ TAXAS POR FAIXA ETÁRIA } \\
\hline & ADMITIDOS & \%ADMITIDOS & DEMITIDOS & TURNOVER \\
De 14 a 19 anos & 72 & 2,21 & 5 & 5,99 \\
De 20 a 29 anos & 2.143 & 65,86 & 2.616 & 14,09 \\
De 30 a 39 anos & 810 & 24,89 & 3.018 & 15,33 \\
De 40 a 44 anos & 105 & 3,23 & 521 & 14,36 \\
De 45 a 49 & 73 & 2,24 & 663 & 11,91 \\
Acima de 50 anos & 51 & 1,57 & 818 & 18,23 \\
Total & 3.254 & 100 & 7.641 & 14,75 \\
\hline
\end{tabular}

A rotatividade por faixa etária foi maior nos colaboradores acima de 50 anos, assim como no Banco do Brasil e no Itaú Unibanco. Provavelmente esse alto índice refere-se à questões relativas à aposentadoria, já tratadas nos bancos analisados anteriormente.

Em relação à diversidade, o Santander afirma que trata de modo transversal a temática em seus modelos de gestão, agregando essa política à área de gestão de pessoas.

As pessoas com deficiência somam 2,7 mil no Santander, que contam com prédios adaptados e hábeis para recebê-los. Um outro aspecto é a disponibilização de softwares para pessoas com deficiência auditiva, tradução em libras e call centers para os deficientes 
auditivos e acessibilidade dos serviços e locais em que o Santander atua com caixas eletrônicos adaptados.

A diversidade de gênero é reportada pelo Santander na medida em que as mulheres representam $59 \%$ do quadro de funcionários. A diversidade sexual também é respeitada pelo banco, com benefícios oferecidos à parceiros do mesmo sexo. Quanto à representação das minorias raciais não foram encontrados dados no relatório anual do Santander.

Com foco na diversidade de geração, o número de funcionários por faixa etária é descrito na Tabela 20 a seguir.

Tabela 20 - Número de Funcionários do Santander discriminados por faixa etária

\begin{tabular}{ll}
\hline \multicolumn{2}{l}{ NÚMERO DE FUNCIONÁRIOS } \\
\hline De 14 a 19 anos & 55 \\
De 20 a 29 anos & 16.869 \\
De 30 a 39 anos & 19.492 \\
De 40 a 44 anos & 4.477 \\
De 45 a 49 & 4.178 \\
Acima de 50 anos & 4.550 \\
Total & 49.621 \\
\hline
\end{tabular}

Para atrair e reter talentos o Santander possui programas tanto de contratação de jovens, quanto de seniores. No caso dos jovens, a rede social Caminhos e Escolhas proporciona orientação profissional de jovens de todo país, e também é utilizada para contratar estagiários e empregados para o banco.

Essa plataforma disponibiliza atividades e recursos de apoio, como jogos e oficinas que abordam a vida financeira, direitos humanos, entre outras temáticas. São mais de 300 mil usuários, e mais de 4 mil contratações por esse meio.

O Santander também participa do Programa de Jovem Aprendiz, desenvolvendo jovens em situações de vulnerabilidade socioeconômica em suas carreiras, contou com 930 participações no ano de 2013.

A Universia, aproximando jovens ao mercado de trabalho, também teve participação no recrutamento e seleção do Santander, preenchendo 736 vagas em 2013.

$\mathrm{Na}$ página eletrônica institucional do Santander, o processo seletivo é descrito em 5 etapas: i) Inscrição; ii) Testes on-line de português, raciocínio lógico e atualidades; iii) Dinâmica de grupo; iv) Entrevistas com gestores do banco; v) Entrevistas com gestores. Além dessas etapas é descrito que se houver necessidade testes de excel e redação serão aplicados 
presencialmente. $\mathrm{O}$ processo seletivo ocorre durante todo o ano e as inscrições podem ser feitas online, no website da empresa.

Dentro das áreas centrais, em São Paulo, as áreas de atuação estão pautadas no Marketing, Produtos, Tecnologia, Recursos Humanos, Riscos, Qualidade, Jurídico, Controladoria, entre outras. Para universitários do último ano, as oportunidades são oferecidas para os que cursam Administração, Ciências da Computação, Ciências Contábeis, Direito, Economia, Engenharias, Estatística, Matemática, Marketing, entre outros. Não há informações sobre parceiros para recrutamento e seleção dos candidatos ao Santander.

A estratégia utilizada nos processos seletivos, como foi observado na descrição dos outros bancos, não costumam ser reportadas com muitos detalhes, o que interfere na análise da área de recrutamento e seleção fundamentado na gestão sustentável de pessoas. Assim, não é possível verificar se os candidatos escolhidos são os que utilizam as questões do TBL para definirem o local onde querem trabalhar, o perfil selecionado não é disponibilizado, se os testes online, dinâmica e entrevistas com gestores também utilizam o TBL, entre outras ações que não permitem examinar a área em profundidade.

Dentro da comunicação da marca e das ações em sustentabilidade organizacional, abordados pelos autores do modelo de gestão sustentável de pessoas, o Santander alega que colocando a Sustentabilidade como centro da estratégia organizacional, três grandes áreas são consideradas importantes para desenvolver o Brasil: inclusão social e financeira, educação e negócios socioambientais.

A área de inclusão social e financeira oferece programas voltados à microempreendedores com pouco acesso ao crédito. $O$ segundo eixo, educação, possui programas de apoio ao ensino superior no Brasil, com 450 instituições de ensino conveniadas, e concedendo, em 2013 mais de 47 mil bolsas de estudo.

Já na área de negócios socioambientais, o Santander acredita na necessidade das empresas e pessoas se adaptarem aos modelos sustentáveis, e nessa onda de tendências tem desenvolvido o fundo de investimentos com as diretrizes dos Princípios de Investimento Sustentável nas Nações Unidas, para promover a temática nos mercados financeiros; tem dispendido de recursos próprios para projetos de energias renováveis; e, análise de risco socioambiental para financiamento de projetos, concessão de créditos e seleção de novos clientes no atacado. 


\subsubsection{SÍNTESE DAS PRÁTICAS DE RECRUTAMENTO E SELEÇÃO}

O Quadro 18 a seguir apresenta uma síntese das práticas encontradas frente ao Recrutamento e Seleção de cada banco analisado. O objetivo foi apresentar um panorama do setor quanto às práticas desse subsistema, elencando os pontos comuns e divergentes, além das diferenças encontradas entre bancos públicos e privados.

Quadro 18 - Síntese das Práticas de Recrutamento e Seleção

\begin{tabular}{|c|c|c|c|c|c|}
\hline Práticas de $R \& S$ & $\begin{array}{l}\text { Banco do } \\
\text { Brasil }\end{array}$ & Itaú Unibanco & $\begin{array}{l}\text { Caixa } \\
\text { Econômica } \\
\text { Federal }\end{array}$ & Bradesco & Santander \\
\hline $\begin{array}{l}\text { Total de } \\
\text { Colaboradores }\end{array}$ & $110 \mathrm{mil}$ & $95 \mathrm{mil}$ & $160 \mathrm{mil}$ & $100 \mathrm{mil}$ & $50 \mathrm{mil}$ \\
\hline $\begin{array}{l}\text { Descrição dos } \\
\text { perfis das vagas } \\
\text { ofertadas em } \\
\text { Conhecimento, } \\
\text { Habilidades e } \\
\text { Atitudes }\end{array}$ & $\begin{array}{l}\text { Não, } \\
\text { especificado } \\
\text { apenas o } \\
\text { conhecimento } \\
\text { exigido. }\end{array}$ & Sim & $\begin{array}{l}\text { Não, } \\
\text { especificado } \\
\text { apenas o } \\
\text { conhecimento } \\
\text { exigido. }\end{array}$ & $\begin{array}{l}\text { Não, apenas } \\
\text { oferece o } \\
\text { cadastro de } \\
\text { currículo no } \\
\text { site. }\end{array}$ & $\begin{array}{l}\text { Não, } \\
\text { especificado } \\
\text { apenas o } \\
\text { conhecimento } \\
\text { exigido e } \\
\text { proporcionado. }\end{array}$ \\
\hline $\begin{array}{l}\text { Descrição das } \\
\text { etapas do processo } \\
\text { seletivo }\end{array}$ & Sim & Sim & Sim & Não & Sim \\
\hline $\begin{array}{l}\text { Processo seletivo } \\
\text { por meio de editais } \\
\text { de concurso }\end{array}$ & Sim & Não & Sim & Não & Não \\
\hline $\begin{array}{l}\text { Seleção de } \\
\text { afrodescendentes }\end{array}$ & $\begin{array}{l}\text { Sim, apresenta } \\
24 \% \text { no seu } \\
\text { quadro de } \\
\text { funcionários }\end{array}$ & $\begin{array}{l}\text { Sim, mas } \\
\text { apresenta } \\
18,8 \% \text { de } \\
\text { representativid } \\
\text { ade no quadro } \\
\text { de funcionários } \\
\end{array}$ & $\begin{array}{l}\text { Sim, apresenta } \\
22,19 \% \text { de } \\
\text { representativid } \\
\text { ade no quadro } \\
\text { de } \\
\text { funcionários. }\end{array}$ & $\begin{array}{l}\text { Sim, apresenta } \\
23,9 \% \text { de } \\
\text { representativid } \\
\text { ade no quadro } \\
\text { de } \\
\text { funcionários. }\end{array}$ & $\begin{array}{l}\text { Não informado } \\
\text { no relatório } \\
\text { anual } \\
\text { analisado. }\end{array}$ \\
\hline $\begin{array}{l}\text { Seleção de } \\
\text { portadores de } \\
\text { necessidades } \\
\text { especiais }(>5 \%)\end{array}$ & $\begin{array}{l}\text { Sim, mas } \\
\text { apenas } 1 \% \text { de } \\
\text { representativid } \\
\text { ade em seu } \\
\text { quadro de } \\
\text { funcionários } \\
\end{array}$ & $\begin{array}{l}\text { Sim, e } \\
\text { apresenta os } \\
5 \% \text { exigidos } \\
\text { por lei. }\end{array}$ & $\begin{array}{l}\text { Sim, mas } \\
\text { apenas } 1,2 \% \text { de } \\
\text { representativid } \\
\text { ade em seu } \\
\text { quadro de } \\
\text { funcionários. } \\
\end{array}$ & $\begin{array}{l}\text { Sim, mas } \\
\text { apenas } 2,1 \% \text { de } \\
\text { representativid } \\
\text { ade em seu } \\
\text { quadro de } \\
\text { funcionários. }\end{array}$ & $\begin{array}{l}\text { Sim, mas } \\
\text { apenas } 0,5 \% \text { de } \\
\text { representativid } \\
\text { ade em seu } \\
\text { quadro de } \\
\text { funcionários. } \\
\end{array}$ \\
\hline $\begin{array}{l}\text { Seleciona sem } \\
\text { discriminação de } \\
\text { gênero. }\end{array}$ & $\begin{array}{l}\text { Sim, mas a } \\
\text { representativid } \\
\text { ade de } \\
\text { mulheres é } \\
42 \%\end{array}$ & $\begin{array}{l}\text { Sim, a } \\
\text { representação } \\
\text { de mulheres no } \\
\text { quadro de } \\
\text { funcionários é } \\
\text { de cerca de } \\
60 \% \text {. }\end{array}$ & $\begin{array}{l}\text { Sim, mas a } \\
\text { representativid } \\
\text { ade de } \\
\text { mulheres é de } \\
45 \% \text {. }\end{array}$ & $\begin{array}{l}\text { Sim, a } \\
\text { representação } \\
\text { de mulheres no } \\
\text { quadro de } \\
\text { funcionários é } \\
\text { de } 49,7 \% \text {. }\end{array}$ & $\begin{array}{l}\text { Sim, a } \\
\text { representação } \\
\text { de mulheres no } \\
\text { quadro de } \\
\text { funcionários é } \\
\text { de } 59 \% \text {. }\end{array}$ \\
\hline $\begin{array}{l}\text { Apresenta } \\
\text { Programa de Jovem } \\
\text { Aprendiz }\end{array}$ & $\begin{array}{l}\text { Não informado } \\
\text { no relatório } \\
\text { anual } \\
\text { analisado. }\end{array}$ & Sim & Sim & $\begin{array}{l}\text { Não informado } \\
\text { no relatório } \\
\text { anual } \\
\text { analisado. }\end{array}$ & Sim \\
\hline $\begin{array}{l}\text { Apresenta } \\
\text { Programa de } \\
\text { Estágio }\end{array}$ & Sim & Sim & Sim & $\operatorname{Sim}$ & $\operatorname{Sim}$ \\
\hline
\end{tabular}




\begin{tabular}{|c|c|c|c|c|c|}
\hline Práticas de $\mathrm{R} \& \mathrm{~S}$ & $\begin{array}{l}\text { Banco do } \\
\text { Brasil }\end{array}$ & Itaú Unibanco & $\begin{array}{l}\text { Caixa } \\
\text { Econômica } \\
\text { Federal }\end{array}$ & Bradesco & Santander \\
\hline $\begin{array}{l}\text { Apresenta } \\
\text { Programa de } \\
\text { Trainees }\end{array}$ & $\begin{array}{l}\text { Não informado } \\
\text { no relatório } \\
\text { anual } \\
\text { analisado. }\end{array}$ & Sim & $\begin{array}{l}\text { Não informado } \\
\text { no relatório } \\
\text { anual } \\
\text { analisado. }\end{array}$ & $\begin{array}{l}\text { Não informado } \\
\text { no relatório } \\
\text { anual } \\
\text { analisado. }\end{array}$ & $\begin{array}{l}\text { Não informado } \\
\text { no relatório } \\
\text { anual } \\
\text { analisado. }\end{array}$ \\
\hline $\begin{array}{l}\text { Candidatos que se } \\
\text { utilizam de } \\
\text { questões sociais, } \\
\text { ambientais e } \\
\text { econômicas para } \\
\text { escolha do local } \\
\text { para trabalhar. }\end{array}$ & $\begin{array}{l}\text { Por ser } \\
\text { concurso } \\
\text { público a } \\
\text { mensuração } \\
\text { dessa } \\
\text { informação é } \\
\text { restrita. }\end{array}$ & $\begin{array}{l}\text { Há } \\
\text { possibilidade } \\
\text { de selecionar } \\
\text { com base } \\
\text { nesses critérios, } \\
\text { porém as } \\
\text { informações } \\
\text { não são } \\
\text { disponíveis } \\
\text { com esses } \\
\text { detalhes. }\end{array}$ & $\begin{array}{l}\text { Por ser } \\
\text { concurso } \\
\text { público a } \\
\text { mensuração } \\
\text { dessa } \\
\text { informação é } \\
\text { restrita. }\end{array}$ & $\begin{array}{l}\text { Há } \\
\text { possibilidade } \\
\text { de selecionar } \\
\text { com base } \\
\text { nesses critérios, } \\
\text { porém as } \\
\text { informações } \\
\text { não são } \\
\text { disponíveis } \\
\text { com esses } \\
\text { detalhes. }\end{array}$ & $\begin{array}{l}\text { Há } \\
\text { possibilidade } \\
\text { de selecionar } \\
\text { com base } \\
\text { nesses critérios, } \\
\text { porém as } \\
\text { informações } \\
\text { não são } \\
\text { disponíveis } \\
\text { com esses } \\
\text { detalhes. }\end{array}$ \\
\hline $\begin{array}{l}\text { Comunicação da } \\
\text { marca e ações de } \\
\text { sustentabilidade } \\
\text { organizacional pela } \\
\text { empresa. }\end{array}$ & $\begin{array}{l}\text { Pelo relatório } \\
\text { anual esse item } \\
\text { não contempla } \\
\text { o público } \\
\text { interno. }\end{array}$ & $\begin{array}{l}\text { Sim, por meio } \\
\text { da educação } \\
\text { financeira, } \\
\text { campanha de } \\
\text { performance } \\
\text { sustentável, } \\
\text { treinamento de } \\
\text { sustentabilidad } \\
\text { e, ombudsman } \\
\text { e pesquisa de } \\
\text { satisfação. Para } \\
\text { o público } \\
\text { externo } \\
\text { proporciona } \\
\text { discussões } \\
\text { sobre } \\
\text { sustentabilidad } \\
\text { e com os } \\
\text { clientes, } \\
\text { presença nas } \\
\text { redes sociais. }\end{array}$ & $\begin{array}{l}\text { Não informado } \\
\text { no relatório } \\
\text { anual } \\
\text { analisado. }\end{array}$ & $\begin{array}{l}\text { Há apenas } \\
\text { discussões } \\
\text { sobre a } \\
\text { temática e } \\
\text { previsão de } \\
\text { iniciativas para } \\
\text { os próximos } \\
\text { anos. }\end{array}$ & $\begin{array}{l}\text { Pelo relatório } \\
\text { anual esse item } \\
\text { não contempla } \\
\text { o público } \\
\text { interno. }\end{array}$ \\
\hline $\begin{array}{l}\text { Escolha de } \\
\text { parceiros em R\&S } \\
\text { conscientes da } \\
\text { sustentabilidade } \\
\text { organizacional. }\end{array}$ & $\begin{array}{l}\text { Uma análise } \\
\text { mais } \\
\text { aprofundada da } \\
\text { Cesgranrio, } \\
\text { responsável } \\
\text { pelo concurso, } \\
\text { é necessária. }\end{array}$ & $\begin{array}{l}\text { Uma análise } \\
\text { aprofundada da } \\
\text { Vagas.com, } \\
\text { responsável por } \\
\text { recrutar e } \\
\text { selecionar os } \\
\text { candidatos é } \\
\text { necessária. }\end{array}$ & $\begin{array}{l}\text { Uma análise } \\
\text { mais } \\
\text { aprofundada da } \\
\text { Cespe/Unb, } \\
\text { responsável } \\
\text { pelo concurso, } \\
\text { é necessária. }\end{array}$ & $\begin{array}{l}\text { Não há } \\
\text { informações } \\
\text { sobre parcerias. } \\
\text { O processo } \\
\text { seletivo fica } \\
\text { centrado no } \\
\text { Banco } \\
\text { Bradesco. }\end{array}$ & $\begin{array}{l}\text { Não há } \\
\text { informações } \\
\text { sobre parcerias. } \\
\text { O processo } \\
\text { seletivo fica } \\
\text { centrado no } \\
\text { Banco } \\
\text { Santander. } \\
\end{array}$ \\
\hline $\begin{array}{l}\text { Utilização de } \\
\text { questões sociais, } \\
\text { ambientais e } \\
\text { econômicas durante } \\
\text { o processo seletivo. }\end{array}$ & $\begin{array}{l}\text { Por ser } \\
\text { concurso } \\
\text { público a } \\
\text { mensuração } \\
\text { dessa } \\
\text { informação é } \\
\text { dificultada. } \\
\end{array}$ & $\begin{array}{l}\text { Para essas } \\
\text { informações } \\
\text { uma } \\
\text { metodologia } \\
\text { com dados } \\
\text { primários seria } \\
\text { necessária. } \\
\end{array}$ & $\begin{array}{l}\text { Por ser } \\
\text { concurso } \\
\text { público a } \\
\text { mensuração } \\
\text { dessa } \\
\text { informação é } \\
\text { dificultada. } \\
\end{array}$ & $\begin{array}{l}\text { Para essas } \\
\text { informações } \\
\text { uma } \\
\text { metodologia } \\
\text { com dados } \\
\text { primários seria } \\
\text { necessária. } \\
\end{array}$ & $\begin{array}{l}\text { Para essas } \\
\text { informações } \\
\text { uma } \\
\text { metodologia } \\
\text { com dados } \\
\text { primários seria } \\
\text { necessária. } \\
\end{array}$ \\
\hline
\end{tabular}

Fonte: Elaborado pela autora.

No Brasil há uma diferença entre os bancos públicos e privados nesse subsistema. Os primeiros selecionam seus candidatos por meio de editais de concurso e os segundos determinam seus próprios meios de atrair e reter talentos. 
Dentro das práticas levantadas, algumas merecem destaque. A descrição dos perfis das vagas ofertadas em geral apresentam as questões técnicas, como formação acadêmica do candidato. Para os concursos públicos os perfis são mais gerais, já que eles geralmente são para nível técnico, diferente do que ocorre no Itaú, onde as vagas são ofertadas com a descrição do cargo, dos conhecimentos exigidos, das habilidades e atitudes esperadas dos candidatos.

Como os processos seletivos são distintos, a vantagem do banco privado é que o perfil pode ser melhor delimitado, como o caso do Itaú, que diferentemente dos outros bancos analisados neste trabalho, disponibiliza uma descrição mais detalhada dos perfis buscados pela instituição.

Essa vantagem dos bancos privados é corroborada pela Febraban. Eles afirmam que os bancos privados conseguem atingir as universidades de primeira linha, captando talentos com uma boa escolaridade. Já os bancos públicos, publicam que um concurso será realizado. Essa diferença culmina em dois perfis diferentes: o de jovens que independentemente do tempo que vão permanecer no emprego, estão interessados nas oportunidades que vão obter, e do outro lado jovens que almejam desenvolver toda sua carreira em uma instituição capaz de proporcionar mais estabilidade e segurança.

Utilizando a Gestão Sustentável de Pessoas, uma outra vantagem do banco privado é a possibilidade de visar candidatos que utilizem as questões ambientais, sociais e econômicas para definirem o local onde ensejam trabalhar. A Febraban concorda que essa ação é possível, mas que por outro lado, nos bancos públicos há possibilidades de internalizar essa consciência nos colaboradores, já que o tempo de permanência nessas instituições é maior que em outros setores brasileiros. Além disso, há possibilidade de englobar os três aspectos do TBL nas descrições de cargo e das vagas dos bancos privados, já visando candidatos mais adeptos à essas questões.

As análises no subsistema de R\&S ficam restritas por não ser uma área que relata detalhadamente suas práticas. Por exemplo, o Bradesco não apresenta as etapas de seus processos de seleção, afirmam apenas que o currículo pode ser enviado e cadastrado na website deles, e que as próximas fases serão comunicadas posteriormente. Os demais bancos, apesar de demonstrarem as etapas de maneira geral, não relatam detalhes que permitam uma análise mais profunda.

Com isso, a proposição 1 (P1) de que os relatórios reportados pelas organizações do setor bancário brasileiro contemplam os tópicos dos subsistemas de gestão de pessoas não se 
valida totalmente no quesito R\&S. Essas práticas não são contempladas nos relatórios, e sim nos websites, e com poucas informações.

Visando à GSP, seria interessante englobar questões do TBL nos testes online, nas dinâmicas, nas entrevistas, ou mesmo nas provas dos concursos públicos, sensibilizando os candidatos à esses temas.

O Censo da Diversidade promovido pela Febraban trouxe que o conhecimento das vagas de emprego nos bancos ocorre principalmente por funcionários do banco e por indicação de amigos e parentes. Além da diminuição dessas indicações entre os anos 2008 e 2014 (cerca de $-6 \%$ no primeiro, e $-1 \%$ no segundo), o alcance da internet tornou-se maior $(8,6 \%)$ bem como os editais de concurso $(21,2 \%)$ também foram mais abrangentes.

Os índices apresentados pelos bancos condizem com o informado pela Febraban. Frente aos afrodescendentes o Santander foi o único que não apresentou informações sobre essa questão, porém os outros bancos ficaram bem próximos à média de $24 \%$ levantada no Censo da Diversidade, e confirmada na entrevista na Febraban.

Apesar do Brasil apresentar cerca de $50 \%$ da população envolvendo pardos e pretos, quando há um extrato do nível de escolaridade que é necessário para os bancos, mesmo para capacitá-los, treiná-los e proporcionar as mesmas oportunidades, apenas $18 \%$ da população brasileira se enquadra nessas exigências. Estas informações trazidas pela Febraban ainda apresentam que à medida que há sucesso nas ações afirmativas gerenciadas pelos bancos, há crescimento no índice de representatividade dessa população no quadro de funcionários.

Para essas ações afirmativas, convênios com a Universidade Zumbi dos Palmares, Secretaria de Igualdade Racial, Afrobase e outras entidades, vem sendo realizados. As vagas de estágio, que é uma porta de entrada nos bancos para nível superior, são priorizadas para candidatos pertencentes à essas instituições. $\mathrm{O}$ banco proporciona capacitações e qualificações profissionais por dois anos, e essas ações tem aumentado os índices de aproveitamento do empregado em suas atividades.

Outro ponto é referente aos programas de Jovem Aprendiz, que apesar de não relatados pelo Banco do Brasil e Bradesco nos relatórios analisados, os outros bancos os apresentam. A Febraban ainda afirma que nesses programas as populações mais vulneráveis são atraídas, com a mesma ideia dos convênios com as entidades envolvendo os afrodescendentes, de permanecerem por dois anos sendo capacitados e qualificados, facilitando o redirecionamento dessas pessoas nos bancos.

Quanto aos portadores de necessidades especiais, o Itaú é o único que cumpre a lei no relatório analisado, com os $5 \%$ do total de colaboradores nesse quesito. Sobre esse tópico, a 
Febraban alega que os bancos privados tem um índice de $76 \%$ de cumprimento dessa lei, sendo alguns bancos com índices abaixo ou acima do que é exigido. Ainda afirma que o setor tem o maior índice de cumprimento da cota, mas que demandou muito esforço e investimento, e que o setor continuará dispendendo os dois para melhorar cada vez mais.

As dificuldades encontradas se pautam principalmente no nível de capacitação profissional dessas pessoas para ingressar nos bancos. O problema social delas não permite só oferecer cursos, mesmo sem custo, elas precisam de subsídios para se locomoverem, se alimentarem, se vestirem. A estratégia do setor foi de contratar essas pessoas como bancárias, para depois proporcionar os cursos e a escolarização. Com isso, cerca de 12 mil pessoas com necessidades especiais compõem o quadro de funcionários atualmente.

Pela visão do Sindicato, a questão da inclusão das pessoas com necessidades especiais apresenta outra perspectiva. Para eles, a iniciativa de alguns bancos de pagar meio salário mínimo para alguns colaboradores, já é uma forma do ministério público e do sindicato não cobrarem a inclusão dessas pessoas no setor. Para fazer a inclusão efetivamente, muitas adaptações são necessárias nas agências, como a acessibilidade das pessoas, adaptação dos equipamentos, etc.

Apesar de desenvolverem modelos de inserção, a Febraban ainda afirma que não é a solução do país para essas questões, já que são 24 milhões de pessoas com deficiência no Brasil, e o setor bancário conta com 500 mil trabalhadores no total. Porém, esses modelos permitem indicar o caminho a ser seguido por outras organizações, já que esperar por medidas advindas do Estado para solucionar essa questão não vai ser viável.

Quanto à questão da igualdade de gênero, o Itaú Unibanco e o Santander apresentam cerca de $60 \%$ dos seus quadros de funcionários representados por mulheres. Esses dados estão acima da média do setor, que é de $50 \%$.

A Febraban alega que desde a segunda metade dos anos 90, a mulher vem apresentando crescimento de escolaridade e capacitação. Mesmo na população universitária, o público feminino tem sido maior que o masculino, e a tendência é de que com essa alta escolaridade e capacitação profissional, elas atuem numa faixa social muito elevada e consequentemente fiquem responsáveis pelos melhores postos de trabalho do banco.

Para a Febraban a questão da diversidade é muito importante, mas as mudanças ocorrem paulatinamente, advindas de planejamento de ações capazes de suprir as necessidades principalmente do âmbito educacional que o Brasil apresenta.

Outro aspecto levantado na GSP, refere-se à comunicação da marca e das ações de sustentabilidade pela organização. Nesse quesito as informações relatadas abordam 
principalmente ações voltadas aos públicos externos às organizações, sendo o Itaú Unibanco o único a apresentar suas atuações para os dois públicos (externo e interno).

As parcerias com organizações de recrutamento e seleção que envolvam a consciência da sustentabilidade organizacional não foram mensuradas neste trabalho, pois Bradesco e Santander não relatam a utilização de parcerias, e nos outros bancos (Itaú, Banco do Brasil e Caixa Econômica Federal), apesar de delegarem essa área à terceiros, o foco deste trabalho não foi analisar essas outras empresas.

Outra questão levantada pelo Sindicato dos Bancários refere-se ao número de trabalhadores que diminuiu ao longo das décadas. Na década de 80 o número chegou a 1 milhão de bancários, passando para 400 mil na década de 90, e nos últimos 10, 12 anos, aumentou para 510 mil. Para eles, esse aumentou foi resultado do investimento em concursos públicos dos últimos governos, do desenvolvimento do país que gerou mais postos de trabalho, mas que atualmente vem recuando.

Com a reestruturação produtiva do setor, após a implantação do Plano Cruzado no Brasil, a onda de demissões foi grande. Além do investimento em automação e informática, visando reduzir os custos e agilizar o atendimento, Silva et al. (2007) afirmam que foram fatores intensificados ao longo dos anos.

A Febraban confirma que essa reestruturação e redução de colaboradores veio principalmente da desverticalização do setor, pois antigamente o mercado brasileiro era muito restrito, a capacidade de produção no Brasil era mínima, a importação não era permitida, o que demandou dos bancos um investimento em outras atividades. Por exemplo, o Bradesco possuía a própria padaria para atender seus colaboradores, a própria empresa de fabricação de móveis, e os funcionários eram considerados bancários, mesmo em funções divergentes das que os bancários exerciam.

A partir da década de 90, com a abertura do mercado brasileiro, e a possibilidade de importação, a redução das atividades divergentes à dos bancários ocorreu. Outro movimento que explica essa redução é da tecnologia, que eliminou funções repetitivas no setor, além da terceirização, onde funções como vigilantes demandam o contrato de empresas especializadas.

O crescimento dos últimos anos na contratação de funcionários, adveio com o crescimento das organizações em geral. As agências passaram de 14 mil para 23 mil no país, além do aumento de postos de atendimento, das atividades comerciais. Com essa expansão, com as fusões e aquisições ocorridas no setor, há possibilidade de sobreposição de funções, o que demandaria um número significativo de demissões. 
O Sindicato informou que três anos atrás, o Itaú demitiu cerca de 3 mil funcionários, sem uma explicação coerente para eles. A Febraban por outro lado, alegou que o ajuste no número de funcionários ficou pautado entre 0,5 e $1 \%$ nos últimos anos, o que pode explicar a decisão do Itaú.

A crítica do Sindicato é quanto o papel social dos bancos, pois demissões refletem não só nos colaboradores, como também em seus familiares, e o setor bancário tem condições de gerar empregos para a sociedade.

Por fim, as informações mais relatadas pelo setor bancário em geral estão pautadas nas taxas de rotatividade, admissão e demissão dos colaboradores, bem como na composição do seu quadro nos termos da diversidade - gênero, faixa etária, região geográfica.

\subsection{TREINAMENTO E DESENVOLVIMENTO}

Esse subsistema de Gestão de Pessoas é responsável por desenvolver projetos e programas que contribuam para a sobrevivência das organizações e sua competitividade. Isto tem sido consequência das constantes alterações econômicas, políticas e sociais que vem influenciando o posicionamento mercadológico das organizações. Neste cenário é esperado uma postura crítica e reflexiva dos profissionais atuantes no desenvolvimento dos colaboradores (MENESES et al., 2010).

\subsubsection{BANCO DO BRASIL}

O Banco do Brasil relata que promove o desenvolvimento dos seus profissionais por meio de planos de carreira, treinamento, avaliação e remuneração alinhados aos seus princípios e valores. Com a plataforma de capacitação conhecida como Universidade Corporativa Banco do Brasil (UniBB), houve uma redução nos gastos com deslocamento e favoreceu o engajamento dos colaboradores com os objetivos organizacionais.

Em 2013 foi informado que foi investido R \$91,7 milhões em educação corporativa, ou $\mathrm{R} \$ 817,17$ por funcionário. Esses programas abrangem as áreas de negócios, melhorias do desempenho profissional, e outros cursos de diferentes modalidades.

A meta anual de treinamento do BB é de 30 horas per capita, mas no ano de 2013 o índice foi de 62 horas. Os índices relativos à treinamento por categoria funcional e por gênero são descritos na Tabela 21 a seguir. 
Tabela 21 - Média de horas de treinamento por gênero e categoria funcional do Banco do Brasil

\begin{tabular}{ll}
\hline Treinamento por gênero e categoria funcional \\
\hline \multirow{2}{*}{ Masculino } & 55,49 \\
Feminino & 58,05 \\
& Técnico \\
Masculino & 37,25 \\
Feminino & 48,15 \\
& Operacional \\
Masculino & 71,13 \\
Feminino & 68,51 \\
& Assessoramento \\
Masculino & 39,93 \\
Feminino & 43,92 \\
& Outros \\
Masculino & 69,61 \\
Feminino & 68,25 \\
\hline
\end{tabular}

O BB oferece treinamentos em Gestão de Segurança por nível funcional, treinamento em Combate à Corrupção, além dos conteúdos relacionados à condução de crédito, que seguem as diretrizes de sustentabilidade. Em 2013 os cursos abordaram:

- $\quad$ Programa ABC (programa para redução da emissão de GEE na agricultura);

- $\quad$ Estratégia de desenvolvimento sustentável;

- $\quad$ Crédito e risco socioambiental;

- $\quad$ Pronaf;

- $\quad$ BB Crédito Acessibilidade;

- $\quad$ Cooperativismo;

- $\quad$ Programa Minha Casa Minha Vida (PMCMV);

- $\quad$ Microcrédito Produtivo Orientado (MPO);

- $\quad$ Fundo de Financiamento Estudantil (Fies).

Além desses dados, o BB informou que houve um incremento em 102\% no número de bolsas de estudos de especializações e 106\% nas bolsas de idiomas para seus colaboradores. Na UniBB ainda há o Programa Caminhos para Aposentadoria, com intuito de incentivar os colaboradores a construírem um projeto de vida no futuro.

Outra área importante do treinamento para uma gestão sustentável é a do agronegócio. $\mathrm{O}$ BB é um dos principais agentes indutores do desenvolvimento dessa área, alinhando os critérios estabelecidos para a manutenção da sustentabilidade socioambiental. 
Técnicas agrícolas sustentáveis, que melhoram a renda, reduzem as emissões de gases de efeito estufa e preserva os recursos naturais, são incentivos proporcionados pelo treinamento dos funcionários nesses temas. Tais conhecimentos impactam na análise e concessão de créditos e financiamentos.

Além do treinamento, a automação de processos e o comprometimento dos funcionários do $\mathrm{BB}$ na disseminação desses fatores, são questões chaves para uma gestão sustentável ser implementada.

\subsubsection{BANCO ITAÚ UNIBANCO}

O T\&D do Banco Itaú-Unibanco é descrito como um dos seus principais valores. A educação continuada incentiva debates sobre temas como ética, sustentabilidade, meritocracia e eficiência.

O Itaú-Unibanco conta com uma escola de negócios que direciona o foco de atuação para atividades relacionadas aos negócios, considerando a abrangência, a especificidade e o público-alvo, e está organizada em três eixos: Centro de Negócios, Centro de Liderança e Programas Institucionais.

O Centro de Negócios elabora um "Currículo de Conhecimento" para cada uma das unidades de negócios, incluindo uma lista das habilidades necessárias para o desempenho de funções de acordo com certas posições. Essa ferramenta orienta os gestores no planejamento e desenvolvimento de recursos humanos, além de visar contribuir para uma alta performance.

O Centro de Liderança é responsável pelas trilhas de conhecimento, que visam o desenvolvimento de líderes, de analistas sênior que demonstram performance destacada até o nível de superintendente e diretores.

E os Programas Institucionais são responsáveis por atender a organização com políticas e programas corporativos comuns às unidades de negócios. Como por exemplo, programas de preparação para certificação, treinamentos técnicos e comportamentais (presenciais e e-learning).

Dentro da Escola Itaú de Negócios, a taxa média de adesão foi de 88,5\%. O número de colaboradores treinados girou em torno de 76 mil, e o incentivo à formação acadêmica chegou a quase 3 mil, totalizando 1,5 milhões de horas. Os cursos tem foco em eficiência e aplicabilidade, com dois indicadores pra melhor gestão dos treinamentos: de processo (orçamento, volumetria e eficiência) e de qualidade (avaliação de reação, de aprendizagem e aplicabilidade). 
Em 2013 foram investidos R\$ 116 milhões em treinamentos, sendo focados nas áreas técnicas, no desenvolvimento das lideranças, por meio do Ciclo de Gestão de Pessoas, e nos programa de talentos.

A média de treinamento por categoria funcional e gênero são apresentadas na Tabela 22 a seguir:

Tabela 22 - Média de Horas em Treinamento por Categoria Funcional e Gênero do Banco Itaú-Unibanco

\begin{tabular}{ll}
\hline MÉDIA DE HORAS EM TREINAMENTO POR CATEGORIA FUNCIONAL E GENERO \\
\hline & Gerencial \\
Masculino & 23 \\
Feminino & 24 \\
& Administrativo \\
Masculino & 21 \\
Feminino & 25 \\
& Produção \\
Masculino & 19 \\
Feminino & 20 \\
& Trainees \\
Masculino & 259 \\
Feminino & 285 \\
Masculino & Estagiários \\
Feminino & 33 \\
\hline
\end{tabular}

Os colaboradores da área de risco ambiental passaram por cursos, capacitações, palestras, treinamentos e grupos de discussão, destacando-se os seguintes eventos:

- Workshop Anual dos Princípios do Equador, para discutir sobre a implantação da nova versão dos princípios;

- IFC Community of Learning, sobre gestão de risco socioambiental em financiamentos corporativos;

- Curso de Especialização em Gestão Ambiental e Negócios no Setor Energético (Instituto de Eletrotécnica e Energia da Universidade de São Paulo), sobre os principais desafios ambientais do setor energético.

Em 2013, cerca de 300 colaboradores da área de Soluções Corporativas receberam treinamentos sobre a Política de Risco Socioambiental e o PSI, com carga horária de quatro horas. Ainda ocorreram palestras e workshops sobre temas como trabalho em condições degradantes; mudanças climáticas; questões polêmicas envolvendo amianto/asbesto; e sustentabilidade aplicada em seguros. 
No mesmo ano, houveram treinamentos para todas as áreas da Diretoria de Seguros Massificados, integrando os Princípios para Sustentabilidade em Seguros no dia a dia das equipes e na estratégia do negócio. O treinamento também resultou em um mapeamento por parte das equipes para a aplicação dos princípios na ótica dos negócios.

O Banco reconhece que a implementação e sensibilização proporcionados aos colaboradores mostraram impactos positivos, dentro do quesito de relevância para que os stakeholders tomem conclusões sobre os desempenhos sociais, econômicos e ambientais da organização.

Outro tipo de treinamento que o Itaú Unibanco proporciona é em combate à corrupção, estabelecendo orientações ao desenvolvimento e manutenção das práticas de prevenção, monitoramento e combate aos atos ou tentativas de corrupção, estabelecimento e gerenciamento de canais de denúncia, além de campanhas de conscientização da problemática.

Ainda é relatado que os resultados financeiros não são exclusividade das metas. Existe o anseio de gerar valor compartilhado, pelo qual as ações são pautadas, além da parceria no desenvolvimento das pessoas, da sociedade e dos países onde atua. As pessoas ao escolherem o Itaú Unibanco para fazerem negócios, criam um valor virtuoso de performance sustentável.

No relatório analisado não foram identificadas informações sobre programas de auxílio aos colaboradores que estão prestes a se aposentarem.

\subsubsection{CAIXA ECONÔMICA FEDERAL}

A CAIXA afirma que a conquista de objetivos, individuais ou organizacionais, está atrelada à capacitação e desenvolvimento dos seus colaboradores. Em 2013, foram mais de $\mathrm{R} \$ 85$ milhões destinados à formação dos empregados, em cursos internos e externos, além do auxílio para os colaboradores matriculados em cursos superiores, pós-graduação e de idiomas.

O Programa de Elevação de Escolaridade CAIXA teve em 2013 mais de 3.500 colaboradores beneficiados, em um investimento de quase $\mathrm{R} \$ 12$ milhões; quase 2 mil funcionários incentivados aos cursos de pós-graduação, com investimento de quase $\mathrm{R} \$ 6$ milhões; e, mais de 2.400 empregados apoiados em cursos de idiomas, ao custo de $\mathrm{R} \$ 3$ milhões.

Uma das principais estratégias utilizadas para a formação de equipes de alta performance é a Universidade CAIXA, de educação corporativa com trabalho em Brasília e São Paulo, além de salas de treinamento distribuídas em 14 filiais de gestão de pessoas. Em 
2013 foram 268 cursos disponibilizados, com a participação de 94\% dos colaboradores, em uma média de 93 horas per capita.

A CEF também proporcionou treinamento relacionado às políticas de direitos humanos, contemplando mais de 26 mil funcionários, e alcançando mais de 440 mil horas. Esse treinamento teve intuito de auxiliar a Caixa a alcançar sua Visão de Futuro. Para a organização, é importante garantir resultados positivos nos eixos econômico, social e ambiental.

O Portal da Universidade CAIXA oferece programas voltados a Responsabilidade Social Empresarial e Cidadania, Auditoria, Mercado Financeiro, Serviços Bancários, Gestão Organizacional e de Pessoas, entre outros.

Além disso, há a ferramenta Wiki. CAIXA, que permite a construção do conhecimento de forma colaborativa, fornecendo aos líderes instrumentos para capacitar suas equipes no próprio ambiente de trabalho.

Entre treinamentos a distância, presenciais ou em serviço, a média de horas de capacitação por empregado foram elencadas por categoria funcional e gênero, descritos na Tabela 23 a seguir.

Tabela 23 - Média de horas de Treinamento por gênero e categoria funcional na CEF

\begin{tabular}{ll}
\hline MÉDIA DE HORAS DE CAPACITAÇÃO POR EMPREGADO \\
\hline \multirow{3}{*}{ Gasculino } & Gerencial \\
Feminino & 63,98 \\
& 62,39 \\
Masculino & Dirigente \\
Feminino & 5,59 \\
& 28 \\
Masculino & Operacional \\
Feminino & 119,14 \\
& 386,36 \\
Masculino & Não gerencial \\
Feminino & 81,13 \\
& 82,58 \\
Masculino & Chefia de unidade \\
Feminino & 101,35 \\
& 104,75 \\
Masculino & Profissional \\
Feminino & 105,72 \\
\hline
\end{tabular}


A CAIXA também proporciona um Programa de Preparação para Aposentadoria, para apoiar e orientar o empregado no processo de desligamento da empresa. Ações como a oficina Vida Futura, para orientar a construção de novos projetos de vida; aconselhamento psicológico, intermediação de participação do empregado em programas de responsabilidade social, apoio ao planejamento financeiro e trocas de conhecimento, são realizadas nesse programa.

Há também o treinamento anticorrupção aos colaboradores, que prevê iniciativas para que não haja lavagem de dinheiro. Em 2013 contou com mais de 54 mil participações, com 34\% dos colaboradores realizando. A CEF afirma também que em 2013 foram identificados 3 casos de corrupção, que resultou em processos administrativos disciplinares e rescisão contratual dos empregados.

No âmbito de treinamento em práticas de segurança, a CAIXA afirma que mantém o serviço de vigilância realizado por empresas especializadas, cabendo a elas capacitarem os funcionários de acordo com as demandas do banco.

Diante de patrocínios, treinamentos externos, despesas com Política Ambiental e associação e adesão à entidades que focam em sustentabilidade, a CAIXA dispendeu mais de R\$ 700 mil em 2013.

Buscando a eficiência energética em edificações, a CAIXA promoveu um seminário voltado aos aspectos técnicos e econômicos de sistemas de energia solar. Esse evento reuniu empregados de diversas áreas e de órgãos parceiros, como Banco do Brasil e Ministério das Minas e Energia. Este trabalho envolveu parcerias para se consolidar.

Treinamentos específicos sugeridos pela Gestão Sustentável de Pessoas, abrangendo o tripé da sustentabilidade, não foram encontrados.

\subsubsection{BANCO BRADESCO}

O Bradesco capacita seus funcionários de maneira personalizada, após mapeamento das competências é analisado as necessidades de aprendizagem do colaborador, e assim planejado o seu desenvolvimento.

Dessa forma, a área de Treinamento se transformou na Universidade Corporativa Bradesco - UniBrad. Formada por nove escolas, conta com os seguintes tópicos:

- Cidadania e Sustentabilidade;

- $\quad$ Excelência Operacional;

- Gente;

- $\quad$ Identidade Organizacional; 
- $\quad$ Inteligência de Negócios;

- $\quad$ Liderança;

- $\quad$ Negócios;

- Relacionamento com o cliente;

- $\quad$ Segurança e Solução Operacional.

Em 2013, o valor investido na área de educação corporativa foi de $\mathrm{R} \$ 126,8$ milhões. Os índices relativos à treinamento por categoria funcional e por gênero por média anual de horas são descritos na Tabela 24 a seguir.

Tabela 24 - Média de horas anual de treinamento

\begin{tabular}{ll}
\hline MÉDIA DE HORAS ANUAL DE TREINAMENTO \\
\hline Gerência \\
Masculino & 53 \\
Feminino & 52 \\
& Administrativo \\
Masculino & 55 \\
Feminino & 49 \\
& Operacional \\
Masculino & 71 \\
Feminino & 77 \\
& Supervisão \\
Masculino & 57 \\
Feminino & 58 \\
& Diretoria \\
Masculino & 66 \\
Feminino & 107 \\
Masculino & Superintendência \\
Feminino & 73 \\
\hline
\end{tabular}

O número médio de horas de treinamento por empregado é de 61 horas. A UniBrad visa estimular o aprendizado pontual e contínuo, desenvolvendo e capacitando as pessoas para desempenharem suas funções.

O Bradesco investe em treinamentos presenciais sobre ética na organização, com orientações, esclarecimento de dúvidas e recebimento de denúncias relativas às violações dos códigos de conduta, às políticas e às normas da empresa.

O Bradesco ainda disponibiliza em sua homepage um curso online sobre economia de energia, e está em desenvolvimento um treinamento para fornecedores, abordando conceitos e práticas sustentáveis a serem adotados por toda a Cadeia de Valor. 
Na Fundação Amazonas Sustentável, o Bradesco em parceria com o governo estadual do Amazonas, desenvolve treinamento de educadores, abordando temas da realidade local e trabalhando as habilidades e competências, capacitando professores. Essa iniciativa visa priorizar a qualidade de vida das comunidades ribeirinhas e a manutenção e conservação ambiental do local.

Quanto aos programas relativos à Segurança no Trabalho, o Bradesco proporciona conscientização e treinamento voltados a todos funcionários para o sigilo das informações, por meio do Programa Corporativo de Conscientização e Educação em Segurança da Informação e da avaliação de riscos, visando a segurança nos produtos, serviços e processos.

Apesar de possuir a área de treinamento e desenvolvimento na instituição, as iniciativas do Bradesco contemplam as questões do tripé da sustentabilidade mais ao público externo (fornecedores, clientes), do que o público interno (colaboradores).

\subsubsection{BANCO SANTANDER}

Em 2013, o Santander investiu $\mathrm{R} \$ 108$ milhões em treinamentos. Dentro desse investimento disponibilizou ainda bolsas de estudo para graduação, idiomas, pós/MBA.

A estratégia de educação e treinamento do Santander está em oferecer capacitações e desenvolvimento para todos os estágios da carreira, estimulando seus profissionais por meio de programas de desenvolvimento locais e internacionais e investimento em formações técnicas e comportamentais dos colaboradores.

Em 2013, o maior foco de investimento foi na evolução dos programas de desenvolvimento de líderes e na estratégia de capacitação para apoiar as funções.

Para atender aos clientes, o banco capacita seus colaboradores e o público externo em vendas consultivas, atendimento diferenciado, cenário macroeconômico e planejamento estratégico. O número de funcionários treinados por temática, estão descritos na Tabela 25 a seguir. 
Tabela 25 - Número de funcionários do Santander treinados em 2013 por temas

\begin{tabular}{|c|c|}
\hline TEMAS & $\begin{array}{c}\text { NÚMERO DE } \\
\text { PESSOAS } \\
\text { TREINADAS EM } 2013 \\
\end{array}$ \\
\hline $\begin{array}{l}\text { Atualizações sobre legislação socioambiental e normatizações do Banco Central do } \\
\text { Brasil }\end{array}$ & 8.469 \\
\hline Compromissos socioambientais voluntários gerais (Protocolo Verde, Pacto Global) & 292 \\
\hline Compromissos socioambientais voluntários específicos (Princípios do Equador, PRI) & 0 \\
\hline Ecoeficiência da instituição, conscientização e educação ambiental & 101 \\
\hline Política Corporativa de responsabilidade socioambiental & 7.326 \\
\hline Produtos e serviços que apresentam adicionalidades socioambientais & 1.550 \\
\hline Direitos Humanos & 6.232 \\
\hline Educação Financeira Pessoal & 18.392 \\
\hline $\begin{array}{l}\text { Orientações aos clientes sobre o melhor uso dos produtos e serviços oferecidos pela } \\
\text { instituição }\end{array}$ & 30.625 \\
\hline Política de compras & 46 \\
\hline $\begin{array}{l}\text { Políticas e procedimentos formais socioambientais em outras linhas de negócio (ex.: } \\
\text { gestão de recursos de terceiros, investimento privado, mercado de capitais e fusões e } \\
\text { aquisições, pesquisa de empresas, tesouraria, comércios exterior, private bank, } \\
\text { seguros, etc. }\end{array}$ & 7.326 \\
\hline
\end{tabular}

Além dos temas supracitados, os colaboradores são capacitados para o combate à corrupção, com palestras, reuniões, cursos online sobre Código de Ética, Prevenção à Lavagem de Dinheiro, Segurança da Informação e Prevenção às Fraudes, que contou com a participação de mais de 34 mil funcionários. O tema também é contemplado nos processos de contratação dos fornecedores que pretendem realizar negócios com o Bradesco.

A área de treinamento e educação do Santander visam melhorar as entregas das áreas, dos funcionários e consequentemente da organização, influenciando o engajamento e envolvimento dos colaboradores, e conectando seus objetivos às estratégias da instituição, o que pode contribuir para resultados positivos do Banco. Além disso, a imagem de boas práticas de benefícios fortalece a imagem do Santander, bem como a área gera um quadro de funcionários que não estão defasados em relação a concorrência.

O primeiro passo é levantar as necessidades de treinamento com os gestores de cada área do negócio, proporcionando um impulso na estratégia do negócio e desenvolvendo os colaboradores em todos os estágios de suas carreiras. Para isso, os responsáveis de cada unidade focam nas Hard Skills, que são cursos em negócios, estratégia, eficiência e voltado ao cliente, e Soft Skills, que é na gestão de pessoas.

$\mathrm{O}$ número médio de treinamento realizado por colaborador, mensurado por gênero e categoria funcional, estão expostos na Tabela 26 a seguir. 
Tabela 26 -Número médio de treinamento por gênero e categoria funcional no Santander

\begin{tabular}{lcc}
\hline CATEGORIA FUNCIONAL & PRESENCIAL + DISTÂNCIA 2013 \\
\hline & Homem & Mulher \\
Operacional & 24,82 & 26,29 \\
Administrativo & 29,92 & 30,94 \\
Especialista & 42,22 & 48,09 \\
Gerencial & 52,3 & 62,8 \\
Diretoria & 60,21 & 48,73 \\
\hline
\end{tabular}

Quanto à orientação financeira, além do treinamento e formação para os colaboradores, outras iniciativas complementam essa abordagem, como vídeos no portal institucional e no Youtube, plataforma de perguntas e respostas no Facebook, Portal da Sustentabilidade com vídeos, cartilhas e planilhas de educação financeira, portal que busca atrair jovens interessados em atuar na área, além de palestras em universidades parceiras e comunidades atendidas pela operação de microcrédito.

Ainda nesse âmbito, o Programa Rio Comunidades foi desenvolvido para capacitar e profissionalizar pessoas da comunidade onde o grupo cultural AfroReggae está inserido. Palestras, iniciativas de assessoria ao empreendedorismo, cursos de educação a distância e bolsas de estudos internacionais foram alguns dos benefícios criados.

Para promover a conscientização e engajamento de clientes, fornecedores e da sociedade nas temáticas da sustentabilidade, o Santander desenvolveu o Espaço de Práticas em Sustentabilidade, gerando e compartilhando as práticas. $\mathrm{O}$ banco fomenta a participação de clientes, funcionários e organizações (parceiros, fornecedores) em programas que envolvem a inserção da sustentabilidade.

No portal de sustentabilidade do Santander diversos materiais, como cartilhas, cursos online e apresentações são disponibilizados com intuito de mostrar a incorporação da sustentabilidade no dia-a-dia das pessoas e empresas. Além disso, publica periodicamente informações sobre o que tem feito para que o tema avance no Santander e permeie cada vez mais os seus negócios e suas práticas de gestão.

Há ainda divulgação de práticas de construção eco eficiente, mostrando os exemplos do que já tem sido feito e os caminhos para se aprofundar neste assunto. Para apoiar os fornecedores, o Santander realizou encontros presenciais com os fornecedores de setores mais críticos frente as questões socioambientais, compartilhando as práticas que auxiliam a redução de riscos sociais e ambientais. O conteúdo foi baseado nas diretrizes do Pacto Global.

Adicionalmente a essas práticas, o banco participou das iniciativas promovidas por organizações parceiras como o Instituto Ethos e o World Resources Institute (WRI), em eventos sobre a sustentabilidade do Brasil. 
A área de Educação do Santander é bastante voltada ao incentivo do desenvolvimento do país. Dessa forma, o Santander busca atuar desde a educação infantil até as Universidades, pois depois de revisar suas estratégias, a inclusão social e econômica passou a fazer parte da sua forma de investimento social. Deste, três objetivos foram delineados: promoção a garantia de direitos das crianças, adolescentes e idosos; favorecimento da inclusão econômica da população brasileira; e, contribuição para a melhoria da escola pública de Educação Básica.

Além disso, uma Divisão Global do Grupo Santander, o Santander Universidades, tem como principal linha de atuação o fomento a iniciativas voltadas à educação superior, estabelecendo parcerias e uma rede de convênios com mais de mil universidades globais.

Quanto aos programas de treinamento em segurança no trabalho, o Santander apenas abordou informações sobre segurança nas informações, e não envolvendo as condições de trabalho de seus colaboradores, visando a prevenção de acidentes, a garantia da saúde e segurança.

Diante das ações supracitadas, percebe-se que o Santander tem dispendido esforços para envolver a sustentabilidade em suas ações.

\section{$\begin{array}{llllll}\text { 4.3.6 SÍNTESE DAS PRÁTICAS DE } & \text { TREINAMENTO E }\end{array}$ DESENVOLVIMENTO}

O Quadro 19 a seguir demonstra a síntese das ações de Treinamento e Desenvolvimento relatadas pelos Bancos.

Quadro 19. Síntese das Práticas de T\&D

\begin{tabular}{|l|l|l|l|l|l|}
\hline $\begin{array}{c}\text { Práticas de } \\
\text { T\&D no Setor } \\
\text { Bancário }\end{array}$ & \multicolumn{1}{|c|}{$\begin{array}{c}\text { Banco do } \\
\text { Brasil }\end{array}$} & Itaú Unibanco & $\begin{array}{c}\text { Caixa } \\
\text { Econômica } \\
\text { Federal }\end{array}$ & Bradesco & Santander \\
\hline $\begin{array}{l}\text { Valor investido } \\
\text { em T\&D }\end{array}$ & $\begin{array}{l}\text { R } \$ 91,7 \\
\text { milhões }\end{array}$ & R\$116 milhões & R $\$ 85$ milhões & $\begin{array}{l}\text { R } \$ 126,8 \\
\text { milhões }\end{array}$ & R\$108 milhões \\
\hline $\begin{array}{l}\text { Treinamento em } \\
\text { questões sociais }\end{array}$ & Sim & Sim & Sim & Sim & Sim \\
\hline $\begin{array}{l}\text { Treinamento em } \\
\text { questões } \\
\text { ambientais }\end{array}$ & Sim & Sim & Sim & Sim & Sim \\
\hline $\begin{array}{l}\text { Treinamento em } \\
\text { questões } \\
\text { econômicas }\end{array}$ & Sim & Sim & Sim & Sim & Sim \\
\hline $\begin{array}{l}\text { Envolve } \\
\text { parceiros para } \\
\text { treinamentos } \\
\text { que incluem o } \\
\text { TBL }\end{array}$ & $\begin{array}{l}\text { Não } \\
\text { informado no } \\
\text { relatório } \\
\text { analisado. }\end{array}$ & Sim & Sim & Sim & Sim \\
\hline $\begin{array}{l}\text { Disponibiliza } \\
\text { cursos internos } \\
\text { envolvendo o } \\
\text { TBL }\end{array}$ & Sim & Sim & Sim & $\begin{array}{l}\text { Não informado } \\
\text { no relatório } \\
\text { analisado. }\end{array}$ & Sim \\
\hline
\end{tabular}




\begin{tabular}{|c|c|c|c|c|c|}
\hline $\begin{array}{c}\text { Práticas de } \\
\text { T\&D no Setor } \\
\text { Bancário } \\
\end{array}$ & $\begin{array}{l}\text { Banco do } \\
\text { Brasil }\end{array}$ & Itaú Unibanco & $\begin{array}{c}\text { Caixa } \\
\text { Econômica } \\
\text { Federal } \\
\end{array}$ & Bradesco & Santander \\
\hline $\begin{array}{l}\text { Disponibiliza } \\
\text { cursos externos } \\
\text { envolvendo o } \\
\text { TBL }\end{array}$ & $\begin{array}{l}\text { Não } \\
\text { informado no } \\
\text { relatório } \\
\text { analisado. }\end{array}$ & Sim & $\begin{array}{l}\text { Não informado } \\
\text { no relatório } \\
\text { analisado. }\end{array}$ & $\begin{array}{l}\text { Sim, para a } \\
\text { questão } \\
\text { ambiental, mas } \\
\text { está } \\
\text { desenvolvendo } \\
\text { outros cursos } \\
\text { para seus } \\
\text { fornecedores. }\end{array}$ & Sim \\
\hline $\begin{array}{l}\text { Treina as } \\
\text { lideranças para } \\
\text { as questões do } \\
\text { TBL }\end{array}$ & $\begin{array}{l}\text { Não } \\
\text { informado no } \\
\text { relatório } \\
\text { analisado. }\end{array}$ & $\begin{array}{l}\text { Sim, houve } \\
\text { treinamento para a } \\
\text { diretoria de } \\
\text { seguros } \\
\text { envolvendo os } \\
\text { princípios da } \\
\text { sustentabilidade, e } \\
\text { um mapeamento } \\
\text { para aplicação } \\
\text { desta ótica nos } \\
\text { outros negócios. } \\
\end{array}$ & $\begin{array}{l}\text { Não informado } \\
\text { no relatório } \\
\text { analisado. }\end{array}$ & $\begin{array}{l}\text { Não informado } \\
\text { no relatório } \\
\text { analisado. }\end{array}$ & $\begin{array}{l}\text { Sim, o maior } \\
\text { investimento } \\
\text { em treinamento } \\
\text { foram para } \\
\text { gerentes e } \\
\text { diretores. }\end{array}$ \\
\hline $\begin{array}{l}\text { Incentiva a } \\
\text { educação dos } \\
\text { colaboradores }\end{array}$ & Sim & Sim & Sim & $\begin{array}{l}\text { Não informado } \\
\text { no relatório } \\
\text { analisado. }\end{array}$ & Sim \\
\hline $\begin{array}{l}\text { Possui Entidade } \\
\text { Estudantil } \\
\text { própria }\end{array}$ & $\begin{array}{l}\text { Sim, a } \\
\text { Universidade } \\
\text { Corporativa - } \\
\text { UniBB }\end{array}$ & $\begin{array}{l}\text { Sim, a Escola Itaú } \\
\text { de Negócios. }\end{array}$ & $\begin{array}{l}\text { Sim, } \\
\text { Universidade } \\
\text { CAIXA. }\end{array}$ & Sim, UniBrad. & $\begin{array}{l}\text { Sim, a } \\
\text { Universidade } \\
\text { Santander. }\end{array}$ \\
\hline $\begin{array}{l}\text { Possui Entidade } \\
\text { Estudantil } \\
\text { própria }\end{array}$ & $\begin{array}{l}\text { Sim, a } \\
\text { Universidade } \\
\text { Corporativa } \\
\text { Banco do } \\
\text { Brasil-UniBB }\end{array}$ & $\begin{array}{l}\text { Sim, a Escola Itaú } \\
\text { de Negócios. }\end{array}$ & $\begin{array}{l}\text { Sim, } \\
\text { Universidade } \\
\text { CAIXA. }\end{array}$ & Sim, UniBrad. & $\begin{array}{l}\text { Sim, a } \\
\text { Universidade } \\
\text { Santander. }\end{array}$ \\
\hline $\begin{array}{l}\text { Treinamento em } \\
\text { segurança no } \\
\text { trabalho }\end{array}$ & Sim & Sim & $\begin{array}{l}\text { Não, é } \\
\text { terceirizado. }\end{array}$ & $\begin{array}{l}\text { Não informado } \\
\text { no relatório } \\
\text { analisado. }\end{array}$ & $\begin{array}{l}\text { Não informado } \\
\text { no relatório } \\
\text { analisado. }\end{array}$ \\
\hline $\begin{array}{l}\text { Treinamento em } \\
\text { Combate à } \\
\text { Corrupção }\end{array}$ & Sim & Sim & Sim & Sim & Sim \\
\hline $\begin{array}{l}\text { Programa de } \\
\text { Preparação para } \\
\text { Aposentadoria }\end{array}$ & Sim & $\begin{array}{l}\text { Não informado no } \\
\text { relatório } \\
\text { analisado. }\end{array}$ & Sim & $\begin{array}{l}\text { Não informado } \\
\text { no relatório } \\
\text { analisado. }\end{array}$ & Não. \\
\hline
\end{tabular}

Fonte: Elaborado pela autora.

A área de T\&D visa garantir de modo articulado o atendimento das metas de desenvolvimento das pessoas e das organizações. Envolver as questões da sustentabilidade organizacional, ou seja, os aspectos sociais, econômicos e ambientais, são primordiais para engajar os funcionários e os stakeholders em ações e comportamentos que contemplem essas áreas. 
Para a Febraban essa área tem recebido muitos investimentos, pois para construir um ambiente de trabalho sustentável é primordial a forte participação dos colaboradores. Alguns bancos estão mais avançados nessas questões que outros, mas a preocupação é grande principalmente para liberação de créditos, já que consequentemente o colaborador responsável por essa atividade gera riscos para o banco, caso faça uma análise errônea e sem consciência desses aspectos.

De modo geral, as posições que oferecem maior risco tem sido prioridades nos treinamentos, porém, conforme essa conscientização vai crescendo, as outras posições do banco passam a receber capacitações nessas áreas. Esse processo é demorado e difícil, de acordo com a Febraban.

De modo geral, no quadro pode-se observar que os bancos tem dispendido esforços para contemplar as temáticas da sustentabilidade organizacional em suas ações de treinamento e desenvolvimento. Investem em treinamentos das lideranças, dos colaboradores, dos stakeholders, disponibilizam cursos online, financiam outras formas de educação, atendendo o público interno e as comunidades em geral, entre outras atividades.

O Banco do Brasil ainda precisa reportar as ações envolvendo o TBL nos treinamentos para as lideranças e o público externo. O Itaú descreve suas iniciativas de treinamento na maioria dos aspectos sugeridos pela GSP, faltando apenas um programa de preparação para aposentadoria. Foi o banco que mais demonstrou ações de GSP no T\&D.

A CEF também precisa reportar as ações envolvendo o TBL para cursos externos e lideranças, além de informações quanto ao treinamento em segurança no trabalho, que afirma apenas que é terceirizado. O Santander não possui treinamento de preparação para aposentadoria e também não apresenta informações sobre a segurança no trabalho, quesitos importantes da GSP para os colaboradores.

O Bradesco foi o banco que menos reportou suas iniciativas frente aos treinamentos. Apesar de possuir a UniBrad, não apresenta informações quanto ao incentivo à educação dos seus colaboradores, seus cursos externos são voltados mais ao aspecto ambiental e não contemplam o social e econômico. Além disso, o programa de preparação para aposentadoria e treinamento em segurança no trabalho não foram apresentados.

Unindo esse subsistema à sustentabilidade organizacional, programas de treinamento e desenvolvimento envolvendo as questões do tripé da sustentabilidade (social, ambiental e econômico) possibilitam maior conhecimento e consciência dessas premissas nos colaboradores. Essa sensibilização pode refletir em uma cultura organizacional mais proativa, 
onde os funcionários podem inserir essas temáticas em suas ações diárias, contribuindo para uma gestão sustentável tanto interna, quanto externa.

\subsection{GESTÃO DE DESEMPENHO E AVALIAÇÃo, SISTEMA DE PAGAMENTO E RECOMPENSA}

Os subsistemas de Gestão de Desempenho e Avaliação e o Sistema de Pagamento e Recompensa costumam estar interligados. Para valorizar o colaborador, compensando o que ele vem entregando de resultados, é preciso avaliar o seu desempenho e recompensá-lo por isso.

A importância desses subsistemas está no incentivo aos funcionários para que desenvolvam habilidades, atitudes e conhecimentos que visam alcançar as metas organizacionais. As avaliações e as consequentes recompensas financeiras e não financeiras são importantes para contribuir para uma gestão ambiental eficiente, bem como para os outros dois aspectos do triple bottom line, o social e econômico (JABBOUR, SANTOS e NAGANO, 2008).

\subsubsection{BANCO DO BRASIL}

O Banco do Brasil, por ser público, possui algumas entraves na gestão de avaliação e desempenho e seu sistema de pagamento e recompensa. Suas remunerações são fixas, conforme a Lei $n^{\circ}$ 9.292/9.

Das análises de desempenho, 98,7\% dos colaboradores a recebem regularmente. Além disso, o Conselho de Administração tem como função orientar as decisões para o período de cinco anos, com ações e metas que abranjam os desempenhos econômico, social e ambiental.

O Programa de Gestão de Desempenho Profissional por Competências e Resultados é utilizado para acompanhar e avaliar os colaboradores do BB. A análise foi feita em 360 graus e foram considerados 5 perspectivas: Financeira, Clientes, Processos Internos, Aprendizado e Crescimento, e por último o Socioambiental.

Além das competências, esse modelo de avaliação mensura também as contribuições individuais no atendimento das metas estabelecidas. Isso contribui para a valorização do mérito na ascensão da carreira.

Como é um banco público, com carreira pautada em mérito, processo seletivo por concurso, o sistema de remuneração e recompensas acaba sendo fixado. Apesar disso, ainda 
existem diferenças entre a equidade de remuneração de gêneros, como detalhado na Tabela 27 a seguir.

Tabela 27 - Remuneração por gênero e categoria funcional do Banco do Brasil

\begin{tabular}{lc}
\hline Remuneração por gênero e categoria funcional \\
\hline \multirow{2}{*}{ Masculino } & Gerencial \\
Feminino & $8.948,43$ \\
& $7.580,47$ \\
Masculino & Técnico \\
Feminino & $8.070,13$ \\
& $7.324,78$ \\
Masculino & Operacional \\
Feminino & $4.274,76$ \\
& $4.135,68$ \\
Masculino & Assessoramento \\
Feminino & $9.449,82$ \\
& $9.136,24$ \\
Masculino & Outros \\
Feminino & $3.276,43$ \\
\hline
\end{tabular}

Percebe-se que ainda existe diferença salarial entre os gêneros, o que o Sindicato dos Bancários corrobora, pois mesmo havendo equidade de gênero dentro da organização, as mulheres ainda recebem menos que os homens, nas mesmas posições.

Dentro os benefícios oferecidos aos seus colaboradores pelo BB, o Relatório Anual (2013), p. 71, pode ser consultado com a lista abrangendo todos os tipos.

$\mathrm{O}$ BB ainda alega que alguns programas, como o de Participação nos Lucros ou Resultados (PLR) e o Programa de Desempenho Gratificado (PDG) contribuíram para a satisfação dos funcionários, mas não foram reportadas informações mais detalhadas quanto ao funcionamento desses programas.

Por fim, o entrave da remuneração ser fixa pode tornar o cumprimento dessas ações e metas inviáveis, se apenas o aspecto financeiro for levado em consideração, não havendo benefícios estabelecidos para os colaboradores que sugerem melhorias nas questões do TBL para as ações organizacionais, não havendo bônus gerenciais para bons resultados, nem participação nos lucros e resultados pela alta gerência, a gestão sustentável de pessoas fica comprometida (RENWICK, REDMAN e MAGUIRE, 2013; GREENWOOD, 2012; KRAMAR, 2014; EHNERT, 2009).

Quanto ao engajamento dos funcionários nos temas envolvendo sustentabilidade, o Banco do Brasil alega que a definição dos principais temas que devem ser observados pela 
Administração do Banco e relatados em seus Relatórios Anuais, devem estar alinhados à Agenda 21, direcionando os investimentos, ações e esforços dentro do plano de sustentabilidade dos negócios.

O intuito é envolver e engajar os principais stakeholders a cada dois anos. Para consultar esses públicos, 30 temas são pré-definidos, e são baseados em parâmetros como o Índice Dow Jones de Sustentabilidade, Índice de Sustentabilidade Empresarial da BM\&FBovespa e o Instituto Brasileiro de Defesa ao Consumidor. O debate ocorre em mesas multidisciplinares, favorecendo a troca de opiniões. Há também correlação com os Princípios do Pacto Global.

Para os funcionários, o Projeto Voluntários BB e outras iniciativas como doações em dinheiro, alimentos e outros itens à entidades, são convites para que o público interno se engaje nas diretrizes da sustentabilidade. Dia do Meio Ambiente e Ecologia, Dia Mundial da Água e a Hora do Planeta também são campanhas com esse intuito.

O Código de Ética e das Normas de Conduta do BB também é uma iniciativa de campanha de comunicação interna. Ao realizar negócios e vivenciar no ambiente de trabalho, os valores éticos e morais são muito bem vistos, e através de recursos audiovisuais e vídeos de curta duração, houve um reforço de mensagens de sensibilização e matérias internas sobre os temas. Essa campanha trouxe dilemas éticos vivenciados em situações práticas, a fim de gerar reflexões sobre como os colaboradores devem atuar.

\subsubsection{BANCO ITAÚ UNIBANCO}

A cultura corporativa do Itaú Unibanco é expressa por 10 princípios que visam direcionar como seus negócios são realizados e a abordagem esperada pelas equipes para transformar a visão em realidade. O Nosso Jeito de Fazer tem intuito de reforçar os valores com os colaboradores por meio de iniciativas como: i) alinhar os colaboradores com esses princípios através da avaliação de desempenho; ii) campanhas nos canais de comunicação; iii) eventos, como o Encontro de Líderes.

Esses princípios são:

- Todos pelo cliente: visa oferecer serviços cada vez melhores;

- Paixão pela performance: buscar sempre os melhores desempenhos;

- Liderança ética e responsável: buscar líderes que pensem como donos do negócio e que tenham postura ética, transparente e comprometida em gerar mudanças positivas para todos os públicos do banco; 
- Craques que jogam para o time: o trabalho em equipe é base da organização, valorizando as individualidades mas não o individualismo;

- Foco na inovação e inovação com foco: o objetivo é criar um ambiente que estimule a criatividade constante, o empreendedorismo e a busca por novas respostas as novas questões;

- Processo servindo pessoas: buscar sempre formas de tornar os processos internos mais ágeis e eficientes, preservando a simplicidade;

- Ágil e descomplicado: o cliente é o bem mais valioso, por isso combater a burocracia e investir para descomplicar os processo são objetivos desse princípio;

- Carteirada não vale: a liderança utilizada é a compartilhada, e posições na hierarquia são conquistadas com talento e competência e não devem ser vistas como status.

- Brilho nos olhos: há estímulo a participação dos colaboradores e celebração de suas vitórias.

- Sonho grande: buscar a superação constante, pensando grande e estabelecendo desafios ambiciosos.

O banco Itaú Unibanco possui um programa de gestão de performance, que visa reconhecer o colaborador na medida de seu talento e contribuição. A análise é composta por avaliações individuais, a partir dos resultados das metas pré-estipuladas e pelo nível de aderência aos princípios do Nosso Jeito de Fazer. Ou seja, a avaliação de desempenho conta com as metas propostas, os resultados alcançados e a forma de entrega dos colaboradores.

A partir dessas avaliações há o reconhecimento da performance dos colaboradores e a proposição de ações para o desenvolvimento de suas carreiras, por meio do Planejamento Estratégico de Pessoas (PEP), onde o colaborador é analisado frente a seus pares.

De todos os colaboradores, apenas 56\% foram avaliados no PEP, sendo os demais analisados por uma avaliação individual ou outros modelos específicos. Após as avaliações, o feedback é realizado para mostrar os pontos fortes e as oportunidades de melhorias, além da posição em relação à seus pares.

A partir desses resultados, as decisões de remuneração e desenvolvimento de carreira dos colaboradores são traçadas. Além disso, há possibilidade de um plano de desenvolvimento individual, com um incentivo de prática valiosa de liderança.

Dentro dos aspectos de remuneração o Itaú Unibanco conta com políticas fixas e variáveis, onde são valorizados o desempenho constante do indivíduo. A remuneração variável é aplicada desde analistas até a alta administração. Além do desempenho individual, o resultado financeiro atingido pelo banco e sua sustentabilidade a curto, médio e longo prazo 
são levados em consideração. As metas de cada colaborador estão atreladas à estratégia da sua área, que refletem a estratégia global do Itaú Unibanco.

Os tipos de remuneração variável estão melhores descritos no Quadro 20 a seguir.

Quadro 20 - Tipos de Remuneração Variável Itaú-Unibanco

\begin{tabular}{|l|l|}
\hline \multicolumn{1}{|c|}{$\begin{array}{c}\text { TIPOS DE } \\
\text { VAUNERAÇÃO }\end{array}$} & \multicolumn{1}{c|}{ DESCRIÇÃO } \\
\hline $\begin{array}{l}\text { Participação nos Lucros e } \\
\text { Resultados (PLR) }\end{array}$ & $\begin{array}{l}\text { Distribuição de um percentual do lucro líquido, limitado ao número de } \\
\text { colaboradores ou a um valor definido em acordo de convenção coletiva firmado } \\
\text { com o respectivo sindicato. }\end{array}$ \\
\hline $\begin{array}{l}\text { Participação nos } \\
\text { Resultados (PR) }\end{array}$ & $\begin{array}{l}\text { Programas de participação nos resultados que dependem de nossa performance nos } \\
\text { negócios (exemplo: performance de uma área de negócio) e do desempenho } \\
\text { individual do colaborador. }\end{array}$ \\
\hline $\begin{array}{l}\text { Programa de Participação } \\
\text { Complementar nos }\end{array}$ & $\begin{array}{l}\text { Programas de participação nos resultados que dependem da performance } \\
\text { corporativa (exemplo: performance do Itaú Unibanco Holding). Em algumas } \\
\text { categorias, o valor é definido em acordo com o respectivo sindicato. }\end{array}$ \\
\hline $\begin{array}{l}\text { Programa de Remuneração } \\
\text { por Alto Desempenho } \\
\text { (PRAD) }\end{array}$ & $\begin{array}{l}\text { Participação complementar nos resultados para 20\% dos colaboradores melhores } \\
\text { avaliados, não participantes de programas de PR. }\end{array}$ \\
\hline $\begin{array}{l}\text { Performance Diferenciada } \\
\text { (PD) }\end{array}$ & $\begin{array}{l}\text { Performance Diferenciada (PD) é um programa que abrange os colaboradores em } \\
\text { cargos de liderança ou cargos similares do nosso conglomerado. Outorga } \\
\text { remuneração na forma de nossas ações preferenciais (ITUB4) de forma } \\
\text { diferida. Este modelo considera a avaliação individual e visa premiar os } \\
\text { profissionais que foram destaques em resultados e em comportamento. Tem o } \\
\text { objetivo de fortalecer (i) a gestão de pessoas, (ii) o autodesenvolvimento e (iii) o } \\
\text { desenvolvimento das equipes. }\end{array}$ \\
\hline
\end{tabular}

Fonte: Relatório Anual Consolidado (2013, p. A354).

Dentro dos benefícios oferecidos pelo Itaú Unibanco estão os firmados nos acordos e convenções coletivas de trabalho com sindicatos relevantes, que cobrem as obrigações como: Vale Refeição, Cesta Alimentação, Auxílio Creche/Babá, Vale Transporte, etc. Além desses, taxas e descontos diferenciados, planos de saúde com ampla rede credenciada, parcerias exclusivas, também são oferecidos.

Com o intuito de melhorar a saúde e bem-estar dos colaboradores, outros programas são oferecidos, como Assistência Médica e Odontológica, Previdência Privada Complementar, Seguro de Vida Coletivo, Auxílio Farmácia, Auxílio Educação e o Itaú Unibanco Clube, que oferece serviços em atividades de lazer, recreação, cultura e esportes, visando a promoção da integração e melhoria da qualidade de vida.

Informações a respeito da equidade de remuneração por gênero não foram encontradas no reporte do Relatório Anual.

O Banco Itaú Unibanco apresenta um programa de Gestão de Desempenho e Avaliação e de Sistema de Pagamento e Recompensa muito bem estruturado. Se as metas estabelecidas se pautarem no Nosso Jeito de Ser, abrange as diretrizes do tripé da 
sustentabilidade como propostos pelos autores Renwick, Redman e Maguire (2013), Greenwood (2012), Kramar (2014) e Ehnert (2009).

Essas características refletem no engajamento dos colaboradores na temática. A política de sustentabilidade é aberta ao público e aplicada em toda organização, proporcionando diálogos e promovendo a construção de relacionamentos duradouros. Os canais utilizados são descentralizados, mas a comunicação corporativa está pautada em emails, website e linhas exclusivas.

Neste conceito, o Itaú Unibanco conta com o Banco de Ideias Sustentáveis, uma plataforma interna de engajamento que incentiva os colaboradores a incluir a sustentabilidade em suas atividades diárias, de modo a incorporar essa cultura ao negócio.

A campanha Performance Sustentável foi lançada em 2013. Exemplos de iniciativas geradas por colaboradores, que criaram valor aos stakeholders, proporcionou um conhecimento em maior profundidade aos colaboradores, além do compartilhamento e comentários sobre as iniciativas.

A frequência dos diálogos com stakeholders alterna de acordo com o impacto do tema e o envolvimento do público. As principais formas de engajamento utilizadas são: workshops, materiais informativos, palestras, pesquisas, painéis multistakeholder, fóruns para grupos específicos, diálogos, canais em mídias sociais, negociações, grupos de discussão, parcerias, processos colaborativos, entre outras.

\subsubsection{CAIXA ECONÔMICA FEDERAL}

A área de avaliação de desempenho da CAIXA é sob responsabilidade da VicePresidência de Gestão de Pessoas, no entanto, foi informado que o desafio de adotar a gestão de desempenho e avaliação para evidenciar o impacto do trabalho de cada empregado nos resultados, seria no ano de 2014. A metodologia a ser implantada é a nine box.

Os critérios para a ascensão de carreira dos colaboradores se pautam em mérito e antiguidade. A cada dois anos há um aumento no nível salarial, com concessão de até dois níveis salariais no cargo efetivo, e há também o reconhecimento do esforço individual. A CAIXA ainda relata que utiliza uma Avaliação de Pessoas por Múltiplas Fontes, cruzando informações sobre o estágio de desenvolvimento da força de trabalho aos indicadores do Plano Estratégico.

Ainda há o programa de funções gratificadas, com regras definidas pela empresa. A ascensão ocorre ainda por meio de processos de seleção por competência, garantindo transparência e equidade de oportunidades. 
Quanto as questões de remuneração, a CAIXA conta com uma equipe especializada em monitorar as práticas e estruturas do mercado, a fim de manter a posição competitiva e atrativa para seus talentos.

Para os colaboradores da carreira Administrativa, a remuneração varia de $\mathrm{R} \$ 2.025,00$ a R\$ 5.922,00, com 48 referências (níveis) salariais entre piso e teto. Já na carreira Profissional, nos cargos de advogado, arquiteto, engenheiro e médico do trabalho, há 36 referências salariais, e os salários variam de $\mathrm{R} \$ 4.021,00$ a $\mathrm{R} \$$ 9.463,00 (jornada de quatro horas, exclusiva para médico do trabalho), $\mathrm{R} \$ 6.031,00$ a $\mathrm{R} \$ 14.194,00$ (jornada de seis horas) e de $\mathrm{R} \$ 8.041,00$ a $\mathrm{R} \$ 18.925,00$ (jornada de oito horas).

A proporção entre o menor salário pago na organização em 2013 (R $\$ 2.121,00)$ e o salário mínimo nacional ( $\mathrm{R} \$ 678,00$, conforme Decreto no 7.872, de 26 de dezembro de 2012) ficou em 3,13 vezes.

Os benefícios proporcionados pela CEF somam em 55, entre os previstos em lei e os oferecidos por liberalidade da Instituição. Entre eles: licença paternidade de 10 dias; direito de ausência de até 5 dias no ano para tratar de interesses particulares, podendo acumulá-los ou não, convertendo em espécie; licença maternidade; licença-adoção; plano de saúde com ampla rede e acima do padrão definido pela Agência Nacional de Saúde; e, planos de previdência complementar.

Assim, conclui-se que as práticas adotadas pela CEF não seguem as sugestões de uma gestão sustentável de pessoas. Não há programa de avaliação de desempenho, não havendo mensuração de metas individuais e organizacionais que levem em consideração o TBL, não há remuneração e benefícios que contemplem essa área também, não havendo incentivos pra que os colaboradores hajam dentro da sustentabilidade organizacional (RENWICK, REDMAN e MAGUIRE, 2013; GREENWOOD, 2012; KRAMAR, 2014; EHNERT, 2009).

Como a CEF não apresenta um sistema de avaliação de desempenho e remuneração e benefícios definidos de modo a contemplar os esforços individuais em busca de ações que contemplem o tripé da sustentabilidade, o engajamento empregatício, empowerment e envolvimento dos colaboradores, ficam restritos às motivações pessoais.

Para incentivar seus colaboradores para a adoção de práticas sustentáveis nos processos diários de trabalho, a CEF promove oportunidades de aprendizado e aperfeiçoamento, mas apenas no âmbito ambiental. A educação corporativa da Universidade CAIXA dispõe cursos relativos à sustentabilidade, além da parceria com o Planeta Sustentável da Editora Abril. 
A CEF também informou que os próximos passos nesse âmbito seria a contratação de uma consultoria externa para elaborar programa de educação, com intuito de incorporar a cultura de sustentabilidade nas práticas cotidianas da empresa, estimulando a criatividade, inovação e capacitando os dirigentes para a gestão sustentável dos negócios, processos e relacionamentos, contribuindo para o aperfeiçoamento das políticas e práticas em sustentabilidade organizacional.

\subsubsection{BANCO BRADESCO}

O Bradesco aplicou, em 2012, um programa a fim de avaliar o desempenho focando nos resultados e no comprometimento individual. Denominado Estimativa de Entrega, tem a finalidade de aprimorar e tornar o processo de avaliação mais completo.

Entre os anos de 2012 e 2013, 25,3\% dos colaboradores foram avaliados nesse novo sistema. Em 2013, 82\% dos colaboradores tiveram suas competências mapeadas. Com esses dados, espera-se desenvolver melhorias na capacitação e desenvolvimento dos funcionários. Não foram encontradas mais informações a respeito do processo de avaliação de desempenho do Bradesco.

Quanto aos quesitos de remuneração, o Bradesco alega em seu relatório anual que dentro do montante que a Instituição produz em termos de riqueza, 31,5\% desse valor é direcionado à remuneração dos funcionários.

Outra informação referente à remuneração encontrada no relatório anual é a questão da proporção dela por categorial funcional entre homens e mulheres. A Tabela 28 a seguir mostra os números apresentados pelo Bradesco.

Tabela 28 - Proporção da remuneração entre homens e mulheres - Bradesco

\begin{tabular}{lc}
\hline \multicolumn{2}{c}{ PROPORÇÃO DA REMUNERAÇÃO POR CATEGORIA } \\
\multicolumn{1}{c}{ FUNCIONAL ENTRE HOMENS E } \\
MULHERES \\
\hline Conselho de Administração & $75 \%$ \\
Diretoria Estatutária & $96 \%$ \\
Superintendência & $98 \%$ \\
Gerência & $86 \%$ \\
Supervisão/Técnicos & $92 \%$ \\
Administrativo & $75 \%$ \\
Operacional & $97 \%$ \\
\hline
\end{tabular}

Dentro dos benefícios oferecidos pelo Bradesco estão além dos previstos em lei, (Relatório Anual Bradesco, 2013, p.88):

- $\quad$ Seguro-saúde e odontológico gratuito; 
- $\quad$ Serviço social;

- $\quad$ Assistência psicológica;

- $\quad$ Programa de Qualidade de Vida Viva Bem e o canal de atendimento 0800 Viva Bem;

- Vacinação contra a gripe e o vírus H1N1;

- $\quad$ Área destinada a atividades de lazer em diversas localidades, com piscinas, pista de atletismo, campo de futebol e quadras poliesportivas;

- $\quad$ Linhas de crédito com taxas subsidiadas;

- $\quad$ Seguros de vida e de acidentes pessoais e assistência-funeral (com custos subsidiados);

- Cursos de especialização (atendendo a critérios da Organização);

- $\quad$ Lanches servidos diariamente;

- Descontos em medicamentos nas farmácias credenciadas;

- $\quad$ Empréstimo social (para situações de emergência);

- Canal de compras on-line - ShopFácil Funcionário;

- $\quad$ Plano de Previdência Complementar;

- $\quad$ Plano de contribuição com benefícios definidos para pensão ao cônjuge e ao filho(a); e,

- $\quad$ Aposentadoria por invalidez.

A fim de engajar os públicos estratégicos envolvidos com o Bradesco, práticas de diálogo tem sido estabelecidas. Em 2010 o banco adotou a norma AA1000 para mapear os pontos de melhoria no engajamento dos stakeholders.

Em 2012 houve o Segundo Ciclo de Engajamento de Stakeholders, promovendo diálogos com pessoas de diferentes áreas, especialistas externos em Sustentabilidade, com intuito de identificar oportunidades de avanços em temas prioritários às expectativas desses públicos à Organização.

Outro aspecto abordado pelo Bradesco é relativo ao engajamento dos seus fornecedores frente as estratégias e ações no campo da sustentabilidade, com encontros que contaram com mais de mil fornecedores para abordar a temática.

Apesar das iniciativas de engajamento frente à uma gestão sustentável ter sido começada, os dados consolidados de seus resultados poderão estar nos próximos relatórios anuais. Dentro do proposto de gestão sustentável de pessoas, o Bradesco ainda não reportou 
descritivamente como funcionam suas práticas de avaliação de desempenho e nem a remuneração e benefícios. Não foi possível identificar se a avaliação de desempenho é pautada no TBL, e se as metas da organização o leva em consideração para remunerar, beneficiar e bonificar seus colaboradores e os líderes, que sugerem melhorias nesses aspectos dentro da organização.

\subsubsection{BANCO SANTANDER}

A área de gestão de desempenho, treinamento, desenvolvimento e remuneração caminham juntas conforme descrito pelo Santander. Para os colaboradores serem encaminhados às capacitações, a avaliação de desempenho serve de referência, bem como sua respectiva remuneração variável.

O Santander não divulga em seu relatório anual detalhes do processo de avaliação de desempenho, porém retrata o percentual de empregados que recebem as análises discriminados por gênero e categoria funcional. A primeira classificação traz que dos homens, $90 \%$ recebem as avaliações regulares, frente a 92,14\% das mulheres.

A segunda classificação, por cargo, é descrita na Tabela 29 a seguir:

Tabela 29 - Porcentagem de funcionários por categoria funcional que recebem avaliação de desempenho

\begin{tabular}{lc}
\hline \% DE FUNCIONÁRIOS POR CATEGORIA FUNCIONAL \\
\hline Operacional & 88,08 \\
Administrativo & 93,96 \\
Especialista & 91,32 \\
Gerencial & 81,33 \\
Diretoria & 90,59 \\
\hline
\end{tabular}

Apesar da prática não ser explicitada no relatório anual, o índice de feedback que os colaboradores recebem é acima dos $80 \%$.

As políticas de remuneração também não são descritas no relatório anual do Santander, nem sobre a equidade de remuneração de gêneros.

Como benefícios-padrão concedidos aos colaboradores são elencados: Assistência Médica, Assistência Odontológica, Auxílio Refeição, Auxílio Alimentação, Seguro de Vida e Vale Transporte.

O Santander possui a Pesquisa de Engajamento que visa medir a satisfação e engajamento dos colaboradores. Dentro dos programas desenvolvidos com esse propósito, os destaques foram para os Planos de Ação por áreas e Ações de Desenvolvimento de Liderança. Essa pesquisa é realizada duas vezes por ano com os colaboradores, mas os resultados não são divulgados por serem dados estratégicos. 
Uma outra iniciativa é a Sustentabilidade para Todo Lado, um desafio lançado aos funcionários a testarem seus conhecimentos sobre a área, e praticarem ações sustentáveis, dentro e fora da organização, que teve em 2013 a participação de 21,6\% dos colaboradores.

O engajamento também é aplicado aos fornecedores. O Santander realiza encontros presenciais com setores críticos dos âmbitos socioambientais e de direitos humanos, com intuito de conhecer as práticas, e proporcionar melhorias nos quesitos de sustentabilidade e responsabilidade social empresarial. Os contratos apresentam cláusulas desses aspectos alinhadas às diretrizes do Pacto Global, do qual o Santander é signatário.

Diante do que é sugerido pelo modelo de gestão sustentável de pessoas, o Santander vem apresentando ações frente à Sustentabilidade com intuito de engajar seus funcionários e outros stakeholders à colocarem em prática suas diretrizes.

Alinhar esse engajamento com as metas organizacionais pautadas no tripé da sustentabilidade, as avaliações de desempenho e consequentemente as remunerações e benefícios, é um caminho a ser seguido para a Gestão Sustentável de Pessoas.

\subsubsection{SÍNTESE DAS PRÁTICAS DE SISTEMA DE PAGAMENTO E RECOMPENSA E GESTÃO DE DESEMPENHO E AVALIAÇÃO}

O Quadro 21 a seguir demonstra a síntese das ações de Pagamento e Recompensa e Gestão de Desempenho e Avaliação, e Envolvimento Empregatício, Empowerment e Engajamento relatadas pelos Bancos.

Quadro 21. Síntese das Práticas de SPR e GDA

\begin{tabular}{|l|l|l|l|l|l|}
\hline $\begin{array}{l}\text { Práticas de SPR e } \\
\text { GDA no Setor } \\
\text { Bancário }\end{array}$ & Banco do Brasil & Itaú Unibanco & $\begin{array}{l}\text { Caixa } \\
\text { Econômica } \\
\text { Federal }\end{array}$ & Bradesco & Santander \\
\hline $\begin{array}{l}\text { Possui equidade de } \\
\text { remuneração entre os } \\
\text { gêneros }\end{array}$ & Não & $\begin{array}{l}\text { Não foram } \\
\text { encontradas } \\
\text { informações no } \\
\text { relatório } \\
\text { analisado. }\end{array}$ & $\begin{array}{l}\text { Não foram } \\
\text { encontradas } \\
\text { informações } \\
\text { no relatório } \\
\text { analisado. }\end{array}$ & Não & $\begin{array}{l}\text { Não foram } \\
\text { encontradas } \\
\text { informações no } \\
\text { relatório } \\
\text { analisado. }\end{array}$ \\
\hline $\begin{array}{l}\text { Possui avaliação de } \\
\text { desempenho para } \\
\text { todos seus } \\
\text { colaboradores }\end{array}$ & $\begin{array}{l}\text { Não, apenas } \\
98,7 \% \text { recebem as } \\
\text { avaliações }\end{array}$ & Sim & $\begin{array}{l}\text { Não, apenas } \\
90 \% \text { dos } \\
\text { homens e } \\
92,14 \% \text { das } \\
\text { mulheres } \\
\text { recebem as } \\
\text { avaliações }\end{array}$ \\
\hline $\begin{array}{l}\text { Possui políticas de } \\
\text { remuneração variada }\end{array}$ & Não & Sim & $\begin{array}{l}\text { Não } \\
82 \% \text { recebem } \\
\text { as avaliações }\end{array}$ & $\begin{array}{l}\text { Não foram } \\
\text { encontradas } \\
\text { informações } \\
\text { no relatório } \\
\text { analisado. }\end{array}$ & \begin{tabular}{l} 
Sim \\
\hline
\end{tabular} \\
\hline
\end{tabular}




\begin{tabular}{|c|c|c|c|c|c|}
\hline $\begin{array}{l}\text { Práticas de SPR e } \\
\text { GDA no Setor } \\
\text { Bancário }\end{array}$ & Banco do Brasil & Itaú Unibanco & $\begin{array}{l}\text { Caixa } \\
\text { Econômica } \\
\text { Federal } \\
\end{array}$ & Bradesco & Santander \\
\hline $\begin{array}{l}\text { Possui premiações de } \\
\text { reconhecimento ao } \\
\text { desenvolvimento de } \\
\text { seus funcionários }\end{array}$ & $\begin{array}{l}\text { Não foram } \\
\text { encontradas } \\
\text { informações no } \\
\text { relatório analisado. }\end{array}$ & Sim & $\begin{array}{l}\text { Não foram } \\
\text { encontradas } \\
\text { informações } \\
\text { no relatório } \\
\text { analisado. }\end{array}$ & $\begin{array}{l}\text { Não foram } \\
\text { encontradas } \\
\text { informações } \\
\text { no relatório } \\
\text { analisado. }\end{array}$ & $\begin{array}{l}\text { Não foram } \\
\text { encontradas } \\
\text { informações no } \\
\text { relatório } \\
\text { analisado. }\end{array}$ \\
\hline $\begin{array}{l}\text { Proporciona } \\
\text { participação acionária } \\
\text { aos funcionários }\end{array}$ & $\begin{array}{l}\text { Não foram } \\
\text { encontradas } \\
\text { informações no } \\
\text { relatório analisado. }\end{array}$ & Sim & $\begin{array}{l}\text { Não foram } \\
\text { encontradas } \\
\text { informações } \\
\text { no relatório } \\
\text { analisado. }\end{array}$ & $\begin{array}{l}\text { Não foram } \\
\text { encontradas } \\
\text { informações } \\
\text { no relatório } \\
\text { analisado. }\end{array}$ & $\begin{array}{l}\text { Não foram } \\
\text { encontradas } \\
\text { informações no } \\
\text { relatório } \\
\text { analisado. }\end{array}$ \\
\hline $\begin{array}{l}\text { Recompensa para } \\
\text { sugestões dos } \\
\text { trabalhadores no } \\
\text { sistema de gestão } \\
\text { pautado no TBL }\end{array}$ & $\begin{array}{l}\text { Sim, ascensão na } \\
\text { carreira, mas } \\
\text { possui } \\
\text { remuneração fixa } \\
\text { por ser banco } \\
\text { público. }\end{array}$ & Sim & $\begin{array}{l}\text { Não foram } \\
\text { encontradas } \\
\text { informações } \\
\text { no relatório } \\
\text { analisado. }\end{array}$ & $\begin{array}{l}\text { Não foram } \\
\text { encontradas } \\
\text { informações } \\
\text { no relatório } \\
\text { analisado. }\end{array}$ & $\begin{array}{l}\text { Não foram } \\
\text { encontradas } \\
\text { informações nc } \\
\text { relatório } \\
\text { analisado. }\end{array}$ \\
\hline $\begin{array}{l}\text { Desenvolve } \\
\text { programas de bônus } \\
\text { gerenciais para bons } \\
\text { resultados pautados } \\
\text { no TBL }\end{array}$ & $\begin{array}{l}\text { Não foram } \\
\text { encontradas } \\
\text { informações no } \\
\text { relatório analisado. }\end{array}$ & Sim & $\begin{array}{l}\text { Não foram } \\
\text { encontradas } \\
\text { informações } \\
\text { no relatório } \\
\text { analisado. }\end{array}$ & $\begin{array}{l}\text { Não foram } \\
\text { encontradas } \\
\text { informações } \\
\text { no relatório } \\
\text { analisado. }\end{array}$ & Sim \\
\hline $\begin{array}{l}\text { Inclui metas que } \\
\text { envolvem o TBL nos } \\
\text { programas de } \\
\text { Participação nos } \\
\text { Lucros e Resultados } \\
\text { para alta gerência }\end{array}$ & $\begin{array}{l}\text { Não foram } \\
\text { encontradas } \\
\text { informações no } \\
\text { relatório analisado. }\end{array}$ & Sim & $\begin{array}{l}\text { Não foram } \\
\text { encontradas } \\
\text { informações no } \\
\text { relatório } \\
\text { analisado. }\end{array}$ & $\begin{array}{l}\text { Não foram } \\
\text { encontradas } \\
\text { informações no } \\
\text { relatório } \\
\text { analisado. }\end{array}$ & $\begin{array}{l}\text { Não foram } \\
\text { encontradas } \\
\text { informações no } \\
\text { relatório } \\
\text { analisado. }\end{array}$ \\
\hline $\begin{array}{l}\text { Mensura desempenho } \\
\text { com indicadores } \\
\text { econômicos, sociais e } \\
\text { ambientais }\end{array}$ & Sim. & Sim & $\begin{array}{l}\text { Não foram } \\
\text { encontradas } \\
\text { informações } \\
\text { no relatório } \\
\text { analisado. } \\
\end{array}$ & $\begin{array}{l}\text { Não foram } \\
\text { encontradas } \\
\text { informações } \\
\text { no relatório } \\
\text { analisado. } \\
\end{array}$ & $\begin{array}{l}\text { Não foram } \\
\text { encontradas } \\
\text { informações no } \\
\text { relatório } \\
\text { analisado. }\end{array}$ \\
\hline $\begin{array}{l}\text { Comunica e } \\
\text { proporciona diálogo } \\
\text { com toda organização } \\
\text { sobre } \\
\text { Sustentabilidade } \\
\text { Organizacional }\end{array}$ & Sim & Sim & $\begin{array}{l}\text { Não, apenas } \\
\text { no âmbito } \\
\text { ambiental }\end{array}$ & Sim & Sim. \\
\hline $\begin{array}{l}\text { Define metas e } \\
\text { responsabilidades } \\
\text { para os } 3 \text { âmbitos do } \\
\text { TBL aplicáveis em } \\
\text { todos os níveis } \\
\text { organizacionais }\end{array}$ & $\begin{array}{l}\text { Não foram } \\
\text { encontradas } \\
\text { informações no } \\
\text { relatório analisado. }\end{array}$ & Sim & $\begin{array}{l}\text { Não foram } \\
\text { encontradas } \\
\text { informações } \\
\text { no relatório } \\
\text { analisado. }\end{array}$ & $\begin{array}{l}\text { Não foram } \\
\text { encontradas } \\
\text { informações } \\
\text { no relatório } \\
\text { analisado. }\end{array}$ & $\begin{array}{l}\text { Não foram } \\
\text { encontradas } \\
\text { informações no } \\
\text { relatório } \\
\text { analisado. }\end{array}$ \\
\hline $\begin{array}{l}\text { Avalia as lideranças } \\
\text { com metas e } \\
\text { resultados pautados } \\
\text { no TBL }\end{array}$ & $\begin{array}{l}\text { Não foram } \\
\text { encontradas } \\
\text { informações no } \\
\text { relatório analisado. }\end{array}$ & Sim & $\begin{array}{l}\text { Não foram } \\
\text { encontradas } \\
\text { informações } \\
\text { no relatório } \\
\text { analisado. }\end{array}$ & $\begin{array}{l}\text { Não foram } \\
\text { encontradas } \\
\text { informações } \\
\text { no relatório } \\
\text { analisado. }\end{array}$ & $\begin{array}{l}\text { Não foram } \\
\text { encontradas } \\
\text { informações no } \\
\text { relatório } \\
\text { analisado. }\end{array}$ \\
\hline
\end{tabular}

Fonte: Elaborado pela autora.

De modo geral, o banco Itaú Unibanco mais uma vez foi o que mais reportou detalhes sobre suas políticas nos subsistemas analisados neste tópico. Para uma análise mais 
aprofundada dessas políticas envolvendo as metas e incentivos para os 3 aspectos do tripé da sustentabilidade, uma metodologia primária, estudando as organizações com o pesquisador inserido nelas, e conhecendo as suas práticas seria necessário.

Para o Sindicato dos Bancários, a questão mais relevante nestes subsistemas é relativo à equidade de remuneração entre os gêneros. Uma pesquisa organizada por eles constatou que em 2000 as mulheres recebiam 30\% a menos que os homens; em 2008, o índice baixou para $27 \%$, e atualmente a diferença média é de $23 \%$. Eles ainda alegam que apesar do discurso da equidade de gênero (sendo $50 \%$ dos colaboradores homens e $50 \%$ mulheres), as mulheres ainda ganham menos nas mesmas posições.

Nos acórdãos trabalhistas o número de queixas relativas à diferenças salariais estão representadas na Tabela 30 a seguir.

Tabela 30. Igualdade de remuneração nos acórdãos trabalhistas

\begin{tabular}{lll}
\hline & Diferenças salariais (\%) & Número de funcionários \\
\hline Banco do Brasil & 5,16 & 112.216 \\
Itaú Unibanco & 0,81 & 95.696 \\
CEF & 7,60 & 164.300 \\
Bradesco & 5,26 & 47.999 \\
Santander & 4,05 & 100.489 \\
\hline
\end{tabular}

Nota-se que a CEF é a que apresenta maior número de reclamações, porém é a que contém maior número de funcionários. O Itaú Unibanco é o que possui menos solicitações trabalhistas nesse quesito.

Um outro questionamento levantado pelo Sindicato é que as metas impostas aos colaboradores são muito altas, e mesmo os bancos públicos, para competirem no mercado, passaram a adotá-las. Como o perfil do bancário mudou para vendedores, essas metas não são discutidas com o trabalhador, nem definidas com critérios claros e nem com uma equipe conjunta.

Por outro lado, a Febraban alega que por mais que os bancos sejam destaque no país nos quesitos de remuneração, encontrar o equilíbrio dos desafios estabelecidos aos colaboradores não é uma tarefa simples. É preciso dar desafios e medi-los, para que eles não sejam tão pequenos que as pessoas se frustrem, nem tão grandes a ponto delas não os alcançarem.

As pessoas, sendo únicas, se motivam por diferentes fatores, já que suas percepções, expectativas e necessidades são específicas de cada um. Jabbour e Santos (2008) ainda 
alegam que a autorrealização, autoestima e o desenvolvimento pessoal e profissional estão relacionados ao julgamento individual de cada recompensa proporcionada.

Mais uma vez a percepção individual de cada pessoa reflete nas decisões, pois se uma pessoa consegue receber o desafio com entusiasmo, o mesmo desafio pode deixar outra apavorada. Desse modo, as medições de desempenho devem ser constantes para avaliar tanto as entregas dos resultados quanto os comportamentos dos colaboradores, e dos bancos analisados, apenas o Itaú Unibanco relatou que faz essa avaliações com todos os funcionários. Seria importante que os outros bancos conseguissem atingir todos seus colaboradores também.

Ainda, em 2009, por conta da crise de 2008, a Febraban informou que a remuneração de administradores dos bancos teve modificação, e que essa mudança tem refletido para as outras camadas da gestão. As recompensas incentivam os colaboradores a desenvolverem habilidades, atitudes e conhecimentos que visam alcançar as metas organizacionais. Jabbour et al. (2008) corrobora que tanto as recompensas financeiras quanto as não financeiras são fundamentais para sustentar as organizações.

Nesse caso, os bônus foram proibidos de serem pagos $100 \%$ a vista, ou seja, as pessoas não podem mais produzir resultados em curto prazo. Para isso, $50 \%$ das bonificações devem ser em ações do banco, culminando para os colaboradores que assumam os riscos em conjunto com o banco, a partir das suas tomadas de decisões diárias. Essa responsabilidade coletiva é trazida pela Febraban como uma das melhores formas de controlar os colaboradores sem precisar vigiá-los, ou seja, os engajando.

Para uma Gestão Sustentável de Pessoas, esses subsistemas são muito importantes, já que incentivam a colaboração de todos para que ajam equilibrando suas decisões e ações pautadas no tripé da sustentabilidade.

Partindo ainda dos pressupostos de que para a Sustentabilidade Organizacional acontecer a parte econômica é que levará aos investimentos para ações ambientais e sociais, delinear ações a partir de metas nesses âmbitos, reconhecendo os esforços individuais, recompensando e beneficiando àqueles que se prontificarem a contribuir para uma gestão mais eficiente, são fundamentais.

Dubois e Dubois (2012) ainda trazem que o engajamento gera entusiasmo nos colaboradores, refletindo numa melhoria de desempenho dos projetos. No caso de uma organização que opta pela sustentabilidade, envolver e engajar os colaboradores para que atuem frente às demandas do triple bottom line poderá levar à solução de problemas, geração de soluções, criando vantagens competitivas à ela. 
Schaltegger e Wagner (2006) afirmam que a gestão do desempenho visando a sustentabilidade requer um quadro de gestão capaz de unir as áreas ambientais e sociais com a estratégia comercial e competitiva da organização, e por outro lado integrar as informações ambientais e sociais com as informações de negócios no âmbito econômico e com os relatórios de sustentabilidade.

Engajar e emponderar seus colaboradores os incentivam a fazer melhorias na organização, por meio de sugestões, além da importância que os comportamento gerenciais tem para apoiar e desenvolver essas ideias obtidas através do envolvimento dos funcionários (RENWICK et al., 2013).

Por fim, para alcançar as sugestões dos autores Renwick et al. (2013), Greenwood (2012), Kramar (2014) e Ehnert (2009), a inclusão do triple bottom line nas ações organizacionais se fazem necessárias, e para isso, estudos empíricos nestes bancos se fazem precisos para uma análise mais completa quanto às práticas e metas adotadas. O Banco Itaú Unibanco é destaque em mais esse subsistema, apresentando o maior número de iniciativas reportadas.

\subsection{SAÚDE, SEGURANÇA E QUALIDADE DE VIDA NO TRABALHO}

Os subsistemas de Gestão de Pessoas devem estar todos inter-relacionados. Assim, para atrair e reter talentos em uma organização, é primordial que ela invista na qualidade do local de trabalho (EHNERT, 2009).

As práticas de gestão de pessoas devem ter flexibilidade para construir capacidades de forças de trabalho, que respeitem a gestão da diversidade, os níveis de saúde e segurança no local de trabalho, que vão refletir em preocupações éticas. Além disso, o desempenho da organização deve ser medido com indicadores que agreguem o bem-estar do colaborador, da comunidade ao entorno e da qualidade de vida (KRAMAR, 2014).

\subsubsection{BANCO DO BRASIL}

No Banco do Brasil, os comitês formais de saúde e segurança contam com colaboradores de diferentes níveis hierárquicos. No ano de 2012 o banco reportou que houveram 1.327 acidentes de trabalho. As taxas de lesões, doenças ocupacionais, dias perdidos e absenteísmo estão descritas na Tabela 31 a seguir, separados por região geográfica brasileira. 
Tabela 31 - Taxas de Saúde e Segurança no Trabalho no Banco do Brasil

\begin{tabular}{lcccc}
\hline & $\begin{array}{c}\text { Taxa de } \\
\text { Lesões }\end{array}$ & $\begin{array}{c}\text { Taxa de doenças } \\
\text { ocupacionais }\end{array}$ & $\begin{array}{c}\text { Taxa de dias } \\
\text { perdidos }\end{array}$ & $\begin{array}{c}\text { Taxa de } \\
\text { absenteísmo }\end{array}$ \\
\hline Região Sudeste & 23,86 & 3,26 & 104,26 & 3,65 \\
Região Nordeste & 42,35 & 22,74 & 425,26 & 5,04 \\
Região Norte & 47,53 & 17,38 & 273,42 & 5,4 \\
Região Sul & 16,81 & 5,73 & 77,52 & 3,26 \\
Região Centro- & 22,14 & 7,35 & 132,19 & 3,88 \\
Oeste & & & & \\
\hline
\end{tabular}

Das regiões de atuação do $\mathrm{BB}$, o Nordeste e Norte são as que apresentam maiores taxas de lesões, doenças ocupacionais, dias perdidos e absenteísmo. No ano de 2013 foram registrados dois óbitos, e em 2012, o registro foi de um óbito.

O número de colaboradores com alta incidência de doenças relacionadas à sua ocupação ou com alto risco de doenças não foi informado pela organização. Apesar disso, eles alegam que os tópicos relativos à esses temas são cobertos por acordos formais com sindicatos.

O Banco conta com o Programa de Controle Médico e Saúde Ocupacional (PCMSO) visando assegurar um maior leque de exames com menor periodicidade - e atuando para prevenir, detectar precocemente, monitorar e controlar possíveis danos à saúde.

O BB afirma também que busca a satisfação de seus funcionários, e que seus propósitos vem sendo cumpridos por estarem na listagem das Melhores Empresas para Você Trabalhar, do Guia Você S/A.

$\mathrm{Na}$ última Pesquisa de Satisfação no Trabalho, realizada em 2013, o índice de satisfação dos funcionários cresceu 3,2 \% em comparação com 2012. O Banco do Brasil conseguiu atingir $76 \%$ de favorabilidade, contra $72,8 \%$ do período anterior. Um de seus objetivos estratégicos tem sido aumentar a satisfação de seus funcionários.

Com o intuito de melhorar as práticas de gestão de pessoas, as Equipes de Comunicação e Autodesenvolvimento (Ecoas) tem sido formadas por funcionários de cada dependência do BB, integrados por 8.688 funcionários em 2013. As Ecoas atuam nos temas de responsabilidade socioambiental, ecoeficiência, voluntariado, comunicação interna, clima organizacional, qualidade de vida. Os tipos de ações das Ecoas não são descritas em profundidade.

Há também o Programa de Qualidade de Vida no Trabalho (QVT), que o BB alega ter um conjunto de ações complementares às de saúde ocupacional e de segurança no trabalho. Mas das ações reportadas, apenas a realização da Semana QVT foi identificada, com a presença do Dr. Dráuzio Varella, sobre o impacto das mudanças do estilo de vida na melhoria da saúde, como uma boa alimentação e práticas de atividade física. Eles informam também 
que esse programa seria reformulado, então o próximo relatório de sustentabilidade pode trazer informações extras a respeito.

No âmbito da qualidade de vida, o BB afirma que para o público externo à organização, ao promover a inclusão financeira, de forma a atender às necessidades da população, ele está provocando impactos sociais positivos.

Há também o novo Plano de Funções, que visa estabelecer atribuições e responsabilidades aos colaboradores de forma que mitigue significativamente o banco à exposição do risco de futuras ações trabalhistas.

Em 2013, o BB contou com os seguintes números de queixas trabalhistas registradas: (1) Na empresa: 16.993; (2) No Procon: 13.092; (3) Na Justiça: 54.969. Frente as queixas e reclamações relacionadas aos direitos humanos, o BB alegou que em 2013 não houveram casos registrados.

Diante deste cenário, as queixas trabalhistas foram examinadas. Dos 268 acórdãos finalizados e analisados no ano de 2014, a maior porcentagem encontrada de solicitações pelos ex-funcionários refere-se às horas extras e seus reflexos, totalizando 36,5\%. A Tabela 32 a seguir mostra os resultados.

Tabela 32 - Queixas contra o Banco do Brasil

\begin{tabular}{ll}
\hline QUEIXAS CONTRA O BANCO DO BRASIL & TOTAL (\%) \\
\hline Adicional de Horas Extras & $2,1 \%$ \\
Adicional de Insalubridade / Periculosidade & $0,6 \%$ \\
Doença Profissional & $0,8 \%$ \\
Horas Extras & $29,5 \%$ \\
Indenizações/Assédio Moral & $5,9 \%$ \\
Reflexos / Horas Extras & $7,0 \%$ \\
\hline
\end{tabular}

Nota-se que as queixas de doença profissional estão a menos de $1 \%$, bem como os adicionais de insalubridade e periculosidade. Esses dados retratam o avanço do BB nesses quesitos. Outro ponto a ser destacada é a solicitação de indenizações por assédio moral, muito abordado pelo Sindicato como uma questão a ser avançada e melhorada nos bancos.

\subsubsection{BANCO ITAÚ UNIBANCO}

O Itaú Unibanco oferece programas no âmbito da saúde para auxiliar o bem estar dos seus colaboradores e um estilo de vida saudável. Dentre eles são oferecidos: ginástica laboral, atendimento nutricional, parcerias com academias, check-up dos executivos para uma avaliação completa da saúde, programa de prevenção à doenças sexualmente transmissíveis e AIDS. 
Além desses, oferece o Programa Saúde da Mulher, promovendo ações preventivas, comportamentais e reprodutivas da mulher, Programa Quero Parar de Fumar, com consultas à cardiologistas e subsídios de medicamentos, Programa Depende de Você, sobre prevenção de drogas. Programa Fique Ok, que conta com uma equipe multidisciplinar para apoio pessoal, Programa de Apoio Emocional, com psicólogos e psiquiatras.

Outros programas como Vacina da Gripe, oferecida a todos colaboradores, Orientação ao Gestor sobre Adoecimento no Trabalho, que conta com eventos de encenação teatral com cenário semelhante ao vivido pelo colaborador, e debate com o Médico do Trabalho. E o Programa de Readaptação Profissional, voltado aos colaboradores afastados da organização para que retomem e deem continuidade às suas atividades.

No âmbito de segurança o Itaú Unibanco conta com profissionais da área para gerenciar, manter e desenvolver atividades que contribuam para a segurança do trabalho e das instalações, dos equipamentos e ferramentas utilizadas no negócio.

Dentre as atividades realizadas para essa área estão:

Quadro 22 - Atividades que contribuem para a Segurança do Trabalho no Banco Itaú- Unibanco

\begin{tabular}{|l|l|}
\hline ATIVIDADES & DESCRIÇÃO \\
\hline SIPATs (Semana Interna de Prevenção de Acidentes) & $\begin{array}{l}\text { Em conjunto com a CIPA (Comissão Interna de } \\
\text { Prevenção de Acidentes), o intuito é prever e } \\
\text { sensibilizar os colaboradores quanto ao tema acidente } \\
\text { de trabalho. }\end{array}$ \\
\hline Investigação de Acidentes com Ações Preventivas & $\begin{array}{l}\text { Levantamento das causas dos acidentes para prever } \\
\text { outros casos. }\end{array}$ \\
\hline Análise Ergonômica dos Postos de Trabalho & $\begin{array}{l}\text { Concentra em prever o desconforto do colaborador na } \\
\text { realização das atividades diárias, bem como em } \\
\text { possíveis afastamentos. }\end{array}$ \\
\hline Levantamento Ambiental & $\begin{array}{l}\text { Análise dos níveis de temperatura, iluminação, } \\
\text { unidade relativa ao ar, para se adequar aos níveis } \\
\text { definidos pela legislação vigente. }\end{array}$ \\
\hline $\begin{array}{l}\text { Treinamento de Ajuste Ergonômico } \\
\text { Treinamento E-learning com Representante de }\end{array}$ & $\begin{array}{l}\text { Fornece informações às telefonistas quanto à utilização } \\
\text { correta do mobiliário e equipamentos. }\end{array}$ \\
\hline $\begin{array}{l}\text { Onde não há CIPA, o curso objetiva orientar os } \\
\text { gestores a conduzir os assuntos relacionados a } \\
\text { prevenção de acidentes e doenças ocupacionais. }\end{array}$ \\
\hline $\begin{array}{l}\text { Treinamento E-learning Segurança e Saúde do } \\
\text { Trabalhador }\end{array}$ & $\begin{array}{l}\text { Os colaboradores recebem orientações via e-learning } \\
\text { relacionados a prevenção de acidentes e doenças } \\
\text { ocupacionais, reduzindo o absenteísmo } \\
\text { proporcionando condições para eles evitarem acidentes } \\
\text { e doenças ocupacionais em suas atividades. }\end{array}$ \\
\hline $\begin{array}{l}\text { Consiste na avaliação prévia dos acessórios } \\
\text { ergonômicos para proporcionar conforto aos } \\
\text { colaboradores para exercerem suas atividades. }\end{array}$ \\
\hline
\end{tabular}

Fonte: Relatório Anual Consolidado Itaú Unibanco Holding S.A. (2013, p. A-361).

$\mathrm{Na}$ pesquisa interna de Clima Organizacional foi demonstrado que $77 \%$ dos colaboradores consideram as instalações seguras para se trabalhar. 
Apesar de todas as ações voltadas para melhorar a saúde e segurança no trabalho dos colaboradores, os índices de doenças ocupacionais, lesões, absenteísmo, apesar de não tão relevantes para o tamanho da organização e o número de seus funcionários, ainda se faz presente. A Tabela 33 a seguir mostra as taxas diferenciadas por gênero.

Tabela 33 - Taxas de saúde do Itaú Unibanco por gênero

\begin{tabular}{lcc}
\hline \multicolumn{1}{c}{ TAXAS } & MULHERES & HOMENS \\
\hline Taxa de lesões (TL) & 1,29 & 0,84 \\
Taxa de Dias Perdidos (TDP) & 480,94 & 303,12 \\
Taxa de Doenças Ocupacionais & 1,19 & 0,78 \\
(TDO) & 1,32 & 0,78 \\
Taxa de Absenteísmo (TA) & 0 & 1 \\
Número Absoluto de Óbitos & & \\
\hline
\end{tabular}

Essas taxas ainda apresentam variações quanto à região geográfica a ser analisada, onde as mais altas estão pautadas na região Nordeste, como observado na Tabela 34 a seguir.

Tabela 34 - Taxas de saúde do Itaú Unibanco por região geográfica

\begin{tabular}{lcccc}
\hline \multicolumn{1}{c}{ REGIÃO } & $\begin{array}{c}\text { TAXA DE } \\
\text { LESÕES (TL) }\end{array}$ & $\begin{array}{c}\text { TAXA DE DIAS } \\
\text { PERDIDOS (TDP) }\end{array}$ & $\begin{array}{c}\text { TAXA DE } \\
\text { DOENÇAS } \\
\text { OCUPACIONAIS } \\
\text { (TDO) }\end{array}$ & $\begin{array}{c}\text { TAXA DE } \\
\text { ABSENTÉ́́.SMO } \\
\text { (TA) }\end{array}$ \\
\hline Sul & 1,69 & 930,76 & 1,55 & 0,79 \\
Sudeste & 0,95 & 303,87 & 0,87 & 1,13 \\
Centro-Oeste & 0,68 & 439,31 & 0,68 & 1,13 \\
Nordeste & 2,89 & $1.118,85$ & 2,83 & 1,21 \\
Norte & 0,67 & 313,73 & 0,67 & 0,88 \\
\hline
\end{tabular}

Tratando das comunidades ao entorno das regiões de atuação do Itaú Unibanco, há um programa de identificação de necessidades e oportunidades, avaliando formas de atuação, em conjunto com as lideranças comunitárias e o poder público, visando a melhoria da qualidade de vida dessa população.

Algumas das atividades em 2013 foram: execução de melhorias civis, com foco na acessibilidade de portadores de deficiência e segurança de pedestres; patrocínio de um evento esportivo com jogos e brincadeiras para entretenimento de crianças participantes; manutenção de parques e passarelas, onde a revitalização teve foco nos conceitos sustentáveis, com uso de telhados verdes, pisos de borracha reciclável, mobilidade para pessoas com dificuldades.

Contudo, apesar de todos os esforços, o Itaú Unibanco ainda conta com queixas e reclamações relacionadas às práticas trabalhistas. O canal disponível aos colaboradores para orientação e tratamento dos conflitos interpessoais e de interesses do ambiente corporativo, já foi mencionado anteriormente, o Ombudsman. 
Cada caso recebido por ele recebe um tratamento, e o resultado pode culminar no desligamento do infrator, em uma mudança de área, sanção disciplinar. Em 2013 foram 1.142 manifestações, das quais 1.021 foram solucionadas. E para avaliar os mecanismos de queixa, o Itaú Unibanco conta com Pesquisas de Clima Ético, avaliações, comitês.

Quanto aos processos trabalhistas, o Itaú Unibanco afirma que sindicatos e exfuncionários moveram as ações buscando obter compensação por supostas violações de contratos de trabalho ou direitos trabalhistas previstos em lei. No final de 2013 haviam 57.192 reclamações trabalhistas movidas contra o banco.

Os principais pedidos dos reclamados reportados pelo Itaú Unibanco incluem: diferenças salariais decorrentes da aplicação das 30 horas de trabalho por semana, que beneficia os colaboradores do banco; diferenças salariais decorrentes de horas extras não devidamente registradas no sistema interno; reivindicações em relação ao método para estabelecer a compensação das horas extras trabalhadas; e equiparação salarial.

As ações coletivas trabalhistas movidas referem-se primordialmente da manutenção de planos de saúde, normas de segurança e greves. O Ministério Público do Trabalho também moveu processos frente ao enquadramento sindical, terceirização, doenças ocupacionais, saúde e segurança, determinação de dias de trabalho e cumprimento da cota mínima de pessoas com necessidades especiais. No total, foram gastos aproximadamente um milhão de reais em acordos com ex-funcionários e sentenças da justiça do trabalho.

Dos acórdãos finalizados no ano de 2014, 383 foram analisados do Banco Itaú Unibanco. Destes, assim como no Banco do Brasil, as reclamações advindas por horas extras e seus reflexos, são as mais recorrentes, coincidindo com o que foi reportado no relatório anual do banco. A diferença está nas indenizações por assédio moral, que nos acórdãos representaram quase $7 \%$ das reclamações.

Diante de todos os esforços para proporcionar ações, comitês, iniciativas que visem a saúde, segurança e qualidade de vida no trabalho, o Itaú Unibanco ainda apresenta uma lacuna frente às horas extras. Essa questão pode estar relacionada com a pressão no cumprimento das metas estabelecidas, tanto individuais, quanto da área do colaborador, e que podem estar muito relacionadas ao sistema de avaliação de desempenho, tratada nos tópicos anteriores.

Apesar disso, o Itaú Unibanco apresentou transparência e organização em divulgar esse tipo de informação em seu relatório anual. A Tabela 35 a seguir mostra os tipos de reclamações mais recorrentes e a porcentagem de cada uma relativa ao total encontrado nos acórdãos. 
Tabela 35 - Queixas contra o Itaú Unibanco

\begin{tabular}{lc}
\hline \multicolumn{1}{c}{ QUEIXAS CONTRA O ITAÚ } & TOTAL (\%) \\
\hline Adicional de Horas Extras & $2,68 \%$ \\
Adicional de Insalubridade / Periculosidade & $2,15 \%$ \\
Doença Profissional & $0,36 \%$ \\
Horas Extras & $36,85 \%$ \\
Indenizações / Assédio Moral & $6,98 \%$ \\
Reflexos / Horas Extras & $12,97 \%$ \\
\hline
\end{tabular}

O Itaú Unibanco segue a mesma linha do Banco do Brasil, com recorrência em queixas mais em torno das horas extras e das indenizações por assédio moral, e com percentuais menores de doenças profissionais e adicionais de insalubridade e periculosidade.

\subsubsection{CAIXA ECONÔMICA FEDERAL}

A política de Saúde e Segurança no Trabalho da CEF procura garantir um ambiente interno positivo aos seus colaboradores, contemplando aspectos assistenciais e preventivos, com os programas Saúde na CAIXA e Programa CAIXA de Qualidade de Vida.

Outras ferramentas também são utilizadas para promover o ambiente seguro e saudável para os empregados, como o Programa de Controle Médico de Saúde Ocupacional (PCMSO); a análise ergonômica do trabalho; a Comissão Interna de Prevenção de Acidentes (Cipa), com 100\% dos membros eleitos pelos empregados da CAIXA; os laudos técnicos das condições ambientais do trabalho; e o Programa de Prevenção de Riscos Ambientais.

A Empresa possui, ainda, o Programa de Reabilitação Ocupacional (PRO), destinado a assegurar as condições para reinserção do empregado ao ambiente de trabalho e sua reabilitação ocupacional no retorno de licenças. Em 2013, em reconhecimento a esse programa, a CAIXA foi premiada com o primeiro lugar, na categoria Órgãos Públicos, no 4o Prêmio de Reabilitação e Readaptação Profissional, promovido pelo Centro Brasileiro de Segurança e Saúde Industrial durante o $7^{\circ}$ Congresso de Reabilitação e Readaptação Profissional.

Em linha com os acordos coletivos e com as melhores práticas em relação ao tema, a CAIXA conta ainda com o Grupo de Trabalho Saúde do Trabalhador, comitê formal composto de oito empregados de diferentes níveis hierárquicos - quatro deles fazem parte da entidade sindical Confederação Nacional dos Trabalhadores do Ramo Financeiro (Contraf), representando $100 \%$ dos empregados da CAIXA. 
A CEF também investe em iniciativas voltadas à saúde física, emocional e social dos colaboradores, com projetos de educação e orientação nutricional, promoção da saúde da mulher e do homem, combate ao tabagismo, campanhas de vacinação, entre outros.

As Licenças por Acidente de Trabalho (LAT) são descritas pela CEF em 3 categorias: doença profissional, que são aquelas produzidas ou desencadeadas pelo exercício de determinada atividade; acidentes do trabalho típico, sofrido pelo empregado no local e no horário de trabalho; e, acidentes de trabalho de percurso, sofridos pelo colaborador no percurso rotineiro de sua residência para o local de trabalho e vice-versa. Os números são descritos na Tabela 36 a seguir.

Tabela 36 - Índice de licenças por Acidente de Trabalho da Caixa por gênero

\begin{tabular}{llccc}
\hline & EMPREGADOS & HOMENS & MULHERES & $\begin{array}{c}\text { TOTAL } \\
\text { CAIXA }\end{array}$ \\
\hline & Total de Empregados & 53.787 & 44.411 & 98.198 \\
& Dias Perdidos & 46.980 & 60.175 & 107.155 \\
Doença Profissional & Empregado com LAT & 272 & 334 & 606 \\
& Absenteísmo por LAT & 0,25 & 0,39 & 0,31 \\
Acidente do trabalho & Dias Perdidos & 1.682 & 2.957 & 4.639 \\
Típico & Empregado com LAT & 29 & 75 & 104 \\
\multirow{2}{*}{ Acidente de trabalho de } & Absenteísmo por LAT & 0,01 & 0,02 & 0,01 \\
percurso & Empregado com LAT & 4.851 & 3.482 & 8.333 \\
& Absenteísmo por LAT & 0,03 & 81 & 156 \\
\hline
\end{tabular}

Quanto ao número de colaboradores com alta incidência de doenças relacionadas à sua ocupação ou com alto risco de doenças, a CAIXA alega que não há atividades ocupacionais que apresentam esses riscos.

A CAIXA ainda apresenta o Canal de Relacionamento Interno, acessível pela intranet, onde os colaboradores podem registrar sugestões, elogios, reclamações e denúncias relacionadas às suas atividades e seu cotidiano. Em 2013, foram 68 ocorrências relativas aos temas de direitos humanos, o dobro do ano anterior. Destes, 58 casos eram de assédio moral, um de discriminação racial, cinco de discriminação de gênero, um ligado à orientação sexual e três relativos as pessoas com deficiência.

Porém, dos 293 acórdãos finalizados em 2014 e analisados em profundidade, o maior índice de reclamações encontrados se pautaram, como nos outros bancos na questão das horas extras e seus reflexos, correspondendo a quase $40 \%$ do total.

A Tabela 37 a seguir mostra a recorrência das solicitações e o percentual relativo ao total demandado. 
Tabela 37 - Queixas contra a Caixa Econômica Federal

\begin{tabular}{ll}
\hline QUEIXAS CONTRA CAIXA ECONÔMICA FEDERAL & TOTAL (\%) \\
\hline Adicional de Horas Extras & $5,87 \%$ \\
Adicional de Insalubridade / Periculosidade & $1,09 \%$ \\
Doença Profissional & $0,13 \%$ \\
Horas Extras & $31,60 \%$ \\
Indenizações / Assédio Moral & $4,00 \%$ \\
Reflexos / Horas Extras & $7,73 \%$ \\
\hline
\end{tabular}

$\mathrm{Na} \mathrm{CEF}$, como nos bancos anteriores, os índices relativos às doenças profissionais e adicional de insalubridade e periculosidade são menos recorrentes que as questões abrangendo as horas extras.

\subsubsection{BANCO BRADESCO}

O Bradesco afirma em seu relatório anual que para agir de maneira preventiva está adotando o projeto denominado EHS, que permitirá a realização de exames de saúde individuais dos funcionários. Alguns acordos e parcerias estão em andamento para a realização de exames adimensionais, periódicos e de retorno ao trabalho.

Um sistema informatizado está sendo desenvolvido também, para possibilitar identificar e gerenciar as licenças com prazo menor que 15 dias e quais são os seus motivos. Dentro da composição de colaboradores de diferentes níveis hierárquicos em comitês formais de saúde e segurança, não foram encontradas informações.

Os índices de lesões, doenças ocupacionais, absenteísmo e dias perdidos estão retratados na Tabela 38 a seguir.

Tabela 38 - Indicadores de Segurança e Saúde Ocupacional Bradesco

\begin{tabular}{ll}
\hline INDICADORES DE SEGURANÇA E SAÚDE OCUPACIONAL & $\mathbf{2 0 1 3}$ \\
\hline Lesões & 1.805 \\
$\begin{array}{l}\text { Número total } \\
\text { \% em relação ao quadro total }\end{array}$ & 1,80 \\
Doenças Ocupacionais & \\
Número total & 1.004 \\
\% em relação ao quadro total & 1,00 \\
Número de dias perdidos & \\
Número total & 301.351 \\
Absenteísmo & \\
Dias com falta & 1.264 .510 \\
$\%$ de absenteísmo & 3,75 \\
\hline
\end{tabular}

O número de óbitos e o número de empregados com alta incidência de doenças relacionadas à sua ocupação e o alto risco de doenças não foram informados pelo Bradesco. 
Frente ao tópico de qualidade de vida, desde 2012 o Bradesco conta com o Programa Qualidade de Vida Viva Bem, com ações focadas em Gestação Saudável, Abandono ao Tabagismo, Atividades Físicas, Saúde em forma, tratando de doenças crônicas e Orientação Nutricional.

O 0800 Viva Bem é um canal de assistência ao colaborador, para assuntos profissionais, particulares, afetivos e familiares, disponível de maneira gratuita a todo momento, e obteve uma procura de 2.322 pessoas em 2013.

Apesar das suas práticas de atuação não estarem detalhadas profundamente no último relatório anual disponível, o Bradesco alega que vem recebendo posições em alguns rankings de pesquisas que avaliam clima organizacional, como: i) As 130 Melhores Empresas para Trabalhar - Great Place to Work/ Revista Época; ii) As 150 Melhores Empresas para Você Trabalhar - Revista Você S/A/ Fundação Instituto de Administração; iii) As Melhores na Gestão de Pessoas - Revista Valor Carreira/AON Hewitt; e, iv) As 35 Melhores Empresas para Começar Carreira - Revista Você S/A.

Em relação aos processos trabalhistas, o Bradesco afirmou que em 2013 a relação de processos comparado ao total de pessoas desligadas, foi de 16,6\%. Processos Administrativos, onde foram infringidos artigos da CLT - Consolidação das Leis de Trabalho e Assédio Moral foram os tópicos reportados pelo Bradesco. O primeiro apresentou 368 processos, em um valor de $\mathrm{R} \$ 1.812 .151,45$ e de assédio moral foram 46 processos, em um valor de $\mathrm{R} \$ 1.642 .562,00$.

Ao realizar a comparação com os acórdãos finalizados no ano de 2014, foram 192 do Bradesco, e os índices mais altos coincidem com os reportados no relatório anual. Assim como nos outros bancos já verificados as reclamações por horas extras e seus reflexos são as mais recorrentes, com 46,82\% de aparição, seguido pelas indenizações por assédio moral, recorrente em quase $10 \%$ dos acórdãos. A Tabela 39 a seguir ainda mostra as queixas de doença profissional recorrentes nos acórdãos examinados.

Tabela 39 - Queixas contra o Banco Bradesco

\begin{tabular}{ll}
\hline QUEIXAS CONTRA O BANCO BRADESCO & TOTAL (\%) \\
\hline Adicional de Horas Extras & $1,09 \%$ \\
Adicional de Insalubridade/Periculosidade & $1,09 \%$ \\
Doença Profissional & $3,27 \%$ \\
Horas Extras & $40,29 \%$ \\
Indenizações / Assédio Moral & $9,62 \%$ \\
Reflexos / Horas Extras & $6,53 \%$ \\
\hline
\end{tabular}


Nota-se que o Bradesco apresenta um número maior de queixas relacionadas à doenças profissionais, se comparado com os outros bancos analisados. A recorrência é de 3,27\% no Bradesco, frente aos índices menores que 1\% dos outros bancos. As indenizações por assédio moral também são mais altas (em torno de 2-3\% maior que os outros).

Mesmo o Bradesco apresentando um número de funcionários parecido com o Banco do Brasil (100 mil), o número de queixas trabalhistas nesses quesitos analisados foram maiores no primeiro.

\subsubsection{BANCO SANTANDER}

Dentro desses subsistema, as práticas e índices relativos a saúde, segurança e qualidade de vida no trabalho, não são reportados. Porém, há tópicos relativos a queixas e reclamações trabalhistas.

As áreas de Compliance, SAC e Ouvidoria, além da Gestão de Fornecedores, são responsáveis por tratar as denúncias feitas a cada um dos públicos respectivos. Esses canais tratam de monitorar as ocorrências de abusos em relação a práticas trabalhistas e direitos humanos com funcionários, terceiros e fornecedores. As denúncias que precisam de investigação são encaminhadas a área de gestão de pessoas ou a Superintendência de Ocorrências Especiais - SOE.

No caso de solicitações feitas pelos colaboradores, o prazo é de 45 dias para solucionar a ocorrência. O Canal de Denúncias Santander também apura o que ocorreu, quais as medidas foram implementadas, e de maneira regular reporta ao Comitê Executiva, que acompanha e direciona as ações específicas.

Quando os casos são considerados procedentes, medidas de correção e responsabilização são aplicadas, como advertências, transferência de função ou local de trabalho, até o desligamento ou processo cível competente.

Por meio de mecanismo formal, o número de queixas e reclamações relacionadas a impactos em direitos humanos que foram registradas, processadas e solucionadas, foram:

Tabela 40 -Queixas e reclamações relacionadas aos direitos humanos no Santander

\begin{tabular}{lc}
\hline \multicolumn{1}{c}{ QUEIXAS } \\
\hline Recebidas & 143 \\
Consideradas Procedentes & 73 \\
Solucionadas & 127 \\
Solucionadas em 2013, relativo a 2012 & 35 \\
\hline
\end{tabular}


Em relação as práticas trabalhistas e queixas relacionadas a direitos humanos de fornecedores, o período abrangido pelo relatório não constatou nenhuma incidência.

No caso do Santander, os acórdãos trabalhistas finalizados no ano de 2014 teve um total de 199 analisados nesse trabalho. Destes, os índices mais recorrentes de solicitações também referem-se às horas extras e seus reflexos, como foi encontrado a nos outros bancos analisados, presente em 38,41\% dos casos, e a questão da indenização e assédio moral, presente em quase $8 \%$ dos casos analisados.

A Tabela 41 a seguir apresenta as solicitações nos acórdãos e a frequência relativa ao total representativa.

Tabela 41. Queixas contra o Santander

\begin{tabular}{ll}
\hline QUEIXAS CONTRA O SANTANDER & TOTAL (\%) \\
\hline Adicional de Horas Extras & $2,37 \%$ \\
Adicional de Insalubridade / Periculosidade & $2,09 \%$ \\
Doença Profissional & $1,12 \%$ \\
Horas Extras & $32,68 \%$ \\
Indenizações / Assédio Moral & $7,96 \%$ \\
Reflexos / Horas Extras & $5,73 \%$ \\
\hline
\end{tabular}

Observa-se também que mesmo o índice de recorrência de doenças profissionais ser maior que $1 \%$, o índice é menor que do Bradesco. E as queixas de adicional de insalubridade e periculosidade são maiores no Santander que nos outros bancos analisados.

\subsubsection{SÍNTESE DAS PRÁTICAS DE SAÚdE, SEGURANÇA E QUALIDADE DE VIDA NO TRABALHO}

O Quadro 23 a seguir retrata a síntese das iniciativas frente ao subsistema de Saúde, Segurança e Qualidade de Vida no Trabalho dos bancos analisados.

Quadro 23. Síntese das Práticas de SSQVT

\begin{tabular}{|l|l|l|l|l|l|}
\hline $\begin{array}{l}\text { Práticas de } \\
\text { SSQVT no } \\
\text { Setor Bancário }\end{array}$ & $\begin{array}{l}\text { Banco do } \\
\text { Brasil }\end{array}$ & Itaú Unibanco & $\begin{array}{l}\text { Caixa } \\
\text { Econômica } \\
\text { Federal }\end{array}$ & Bradesco & Santander \\
\hline $\begin{array}{l}\text { Proporciona } \\
\text { jornada de } \\
\text { trabalho razoável }\end{array}$ & $\begin{array}{l}\text { O maior índice } \\
\text { de queixas } \\
\text { trabalhistas é de } \\
\text { horas extras e } \\
\text { seus reflexos. }\end{array}$ & $\begin{array}{l}\text { O maior índice } \\
\text { de queixas } \\
\text { trabalhistas é } \\
\text { de horas extras } \\
\text { e seus reflexos. } \\
\text { queixas } \\
\text { trabalhistas é } \\
\text { de horas } \\
\text { extras e seus } \\
\text { reflexos. }\end{array}$ & $\begin{array}{l}\text { O maior índice de } \\
\text { queixas trabalhistas } \\
\text { é de horas extras e } \\
\text { seus reflexos. }\end{array}$ & $\begin{array}{l}\text { índice de } \\
\text { queixas } \\
\text { trabalhistas é } \\
\text { de horas } \\
\text { extras e seus } \\
\text { reflexos. }\end{array}$ \\
\hline
\end{tabular}




\begin{tabular}{|c|c|c|c|c|c|}
\hline $\begin{array}{l}\text { Práticas de } \\
\text { SSQVT no } \\
\text { Setor Bancário }\end{array}$ & $\begin{array}{l}\text { Banco do } \\
\text { Brasil }\end{array}$ & Itaú Unibanco & $\begin{array}{l}\text { Caixa } \\
\text { Econômica } \\
\text { Federal }\end{array}$ & Bradesco & Santander \\
\hline $\begin{array}{l}\text { Proporciona } \\
\text { iniciativas de } \\
\text { combate ao } \\
\text { assédio moral }\end{array}$ & $\begin{array}{l}\text { Não foram } \\
\text { encontradas } \\
\text { informações no } \\
\text { relatório } \\
\text { analisado. }\end{array}$ & $\begin{array}{l}\mathrm{O} \\
\text { compromisso } \\
\text { em combater é } \\
\text { relatado, mas } \\
\text { não as } \\
\text { iniciativas. }\end{array}$ & $\begin{array}{l}\text { Não foram } \\
\text { encontradas } \\
\text { informações } \\
\text { no relatório } \\
\text { analisado. }\end{array}$ & $\begin{array}{l}\text { Não foram } \\
\text { encontradas } \\
\text { informações no } \\
\text { relatório analisado. }\end{array}$ & $\begin{array}{l}\text { Não foram } \\
\text { encontradas } \\
\text { informações } \\
\text { no relatório } \\
\text { analisado. }\end{array}$ \\
\hline $\begin{array}{l}\text { Proporciona } \\
\text { iniciativas para a } \\
\text { prevenção de } \\
\text { acidentes de } \\
\text { trabalho }\end{array}$ & Sim & Sim & Sim & $\begin{array}{l}\text { Não, o programa } \\
\text { está em } \\
\text { desenvolvimento. }\end{array}$ & $\begin{array}{l}\text { Não foram } \\
\text { encontradas } \\
\text { informações } \\
\text { no relatório } \\
\text { analisado. }\end{array}$ \\
\hline $\begin{array}{l}\text { Proporciona } \\
\text { iniciativas para } \\
\text { promover a } \\
\text { qualidade de } \\
\text { vida }\end{array}$ & Sim & Sim & Sim & Sim & $\begin{array}{l}\text { Não foram } \\
\text { encontradas } \\
\text { informações } \\
\text { no relatório } \\
\text { analisado. }\end{array}$ \\
\hline $\begin{array}{l}\text { Possui políticas } \\
\text { que abrangem o } \\
\text { equilíbrio entre a } \\
\text { vida pessoal e } \\
\text { profissional }\end{array}$ & $\begin{array}{l}\text { Algumas } \\
\text { iniciativas } \\
\text { foram } \\
\text { realizadas, mas } \\
\text { é alegado que o } \\
\text { programa está } \\
\text { sendo } \\
\text { reformulado. }\end{array}$ & Sim & Sim & Sim & $\begin{array}{l}\text { Não foram } \\
\text { encontradas } \\
\text { informações } \\
\text { no relatório } \\
\text { analisado. }\end{array}$ \\
\hline $\begin{array}{l}\text { Os comitês } \\
\text { formais de saúde } \\
\text { e segurança } \\
\text { contam com } \\
\text { colaboradores de } \\
\text { diferentes níveis } \\
\text { hierárquicos }\end{array}$ & Sim & $\begin{array}{l}\text { Não foram } \\
\text { encontradas } \\
\text { informações no } \\
\text { relatório } \\
\text { analisado. }\end{array}$ & Sim & $\begin{array}{l}\text { Não foram } \\
\text { encontradas } \\
\text { informações no } \\
\text { relatório analisado. }\end{array}$ & $\begin{array}{l}\text { Não foram } \\
\text { encontradas } \\
\text { informações } \\
\text { no relatório } \\
\text { analisado. }\end{array}$ \\
\hline $\begin{array}{l}\text { Os tópicos } \\
\text { relativos a saúde } \\
\text { e segurança são } \\
\text { cobertos por } \\
\text { acordos formais } \\
\text { com sindicatos. }\end{array}$ & Sim & Sim & Sim & $\begin{array}{l}\text { Não foram } \\
\text { encontradas } \\
\text { informações no } \\
\text { relatório analisado. }\end{array}$ & $\begin{array}{l}\text { Não foram } \\
\text { encontradas } \\
\text { informações } \\
\text { no relatório } \\
\text { analisado. }\end{array}$ \\
\hline $\begin{array}{l}\text { Relata o número } \\
\text { de queixas } \\
\text { trabalhistas } \\
\text { recebidas. }\end{array}$ & Sim & Sim & Não & Sim & Sim \\
\hline $\begin{array}{l}\text { Relata os tipos } \\
\text { de queixas } \\
\text { trabalhistas } \\
\text { recebidos. }\end{array}$ & Não & Sim & Não & Sim & Não \\
\hline $\begin{array}{l}\text { Relata o número } \\
\text { de óbitos na } \\
\text { organização }\end{array}$ & Sim & Sim & Não & Não & Não \\
\hline
\end{tabular}

Fonte: Elaborado pela autora. 
Uma empresa que quer ser socialmente responsável deve ser sinônima de uma organização "humanizada", não preocupada apenas com os lucros e seus acionistas, mas também com seus colaboradores, desenvolvendo ações no âmbito interno (VERGARA e BRANCO, 2001).

Os trabalhadores mudaram suas percepções a respeito da atividade laboral. O novo enfoque considera as organizações não apenas aquelas que geram problemas, mas sim que promovem a saúde. A organização e seus funcionários passam a ter uma relação central, não só os recrutando e retendo, como também providenciando ferramentas para que se sintam satisfeitos, sejam produtivos, estejam comprometidos e desenvolvam suas capacidades e criatividade (LARSON e LUTHANS, 2006; NADER et al., 2014).

Essa dimensão interna afeta os trabalhadores nos aspectos de saúde e segurança, gestão de pessoas e adaptação às mudanças, ao mesmo tempo em que a externa abrange o meio a qual a organização está inserida e as suas respostas à comunidade onde atua. Como a satisfação dos funcionários está nos aspectos cognitivos e afetivos, os mesmo criam conceitos e sentimentos sobre a empresa a partir do que experimentam, sentem e veem (CÁMARAS, 2006; GABRIUNAS, 2010).

O setor bancário brasileiro sofreu alguns processos de reestruturação devido aos avanços da tecnologia e as modificações organizacionais consequentes. Fenômenos sociais como desemprego, precarização do trabalho e a intensificação do ritmo laboral foram algumas das consequências das novas exigências e qualificações que o setor passou a demandar (SILVA E NAVARRO, 2012; SEGNINI, 1999). Estas afirmações são corroboradas pelo Sindicato dos Bancários e pela Febraban.

Larangeira (1997) e Gravina e Rocha (2006) afirmam que houve redução nos níveis hierárquicos, e as novas funções dos bancários exigem flexibilidade e polivalência. Eles passaram a cumprir o papel de exímios vendedores, sendo cobrados pelo cumprimento das metas estabelecidas pelos níveis hierárquicos superiores, e responsáveis por atividades como consultorias financeiras e a comercialização de produtos e serviços.

O Sindicato alega que essas novas exigências tem adoecido muito dos trabalhadores, principalmente no quesito das metas impostas, que obrigam os bancários a vender uma série de produtos que muitas vezes não é do interesse e nem da necessidade do cliente. Ainda alegam que os bancos, com suas ganâncias, trazem metas cada vez maiores, com o número de funcionários cada vez menor, gerando insatisfação nos clientes diante do número de tarifas que pagam, além dos juros, e o bancário acaba adoecendo diante de tanta pressão. 
As modificações no perfil do bancário influenciaram o surgimento de adoecimentos ocupacionais, elevando a incidência de sofrimentos mentais, sensação de perda de identidade profissional, sentimentos de frustração, pressão psicológica, entre outras queixas que tem sido trazidas pelos trabalhadores (GRAVINA e ROCHA, 2006; SILVA e NAVARRO, 2012).

Por outro lado, a Febraban afirma que os trabalhos repetitivos das agências, como digitadores, foram substituídos por sistemas automatizados que fazem este trabalho. A função passou a ser mais de assessoria ao cliente e de oferta de produtos, voltados principalmente a usuários não clientes, pois os clientes já conseguem fazer suas operações sem precisar ir à agência bancária. Hoje, existem alguns bancos falando em home office (escritório em casa), para que os funcionários tenham tempo de cuidar da casa e da vida pessoal ao mesmo tempo que conseguem ser profissionais remunerados.

Frente às questões de doença profissional, os acórdãos mostraram que a representatividade de solicitações nesse quesito não é muito recorrente, com destaque para o Bradesco que teve um índice maior que os outros bancos. Além disso, os índices por indenizações de assédio moral giraram em torno de 4 a 10\% de representatividade, sendo também o Bradesco com o maior número de solicitações.

A CEF foi instituição que apresentou os menores índices de doença profissional e de indenizações por assédio moral. Quanto ao adicional de insalubridade e periculosidade o Banco do Brasil foi o que apresentou menor recorrência. Os dados podem ser analisados na Tabela 42 a seguir.

Tabela 42. Comparativo de queixas trabalhistas por banco

\begin{tabular}{llllll}
\hline QUEIXAS TRABALHISTAS & BB (\%) & $\begin{array}{l}\text { ITAÚ } \\
(\%)\end{array}$ & $\begin{array}{l}\text { CEF } \\
(\%)\end{array}$ & $\begin{array}{l}\text { BRADESCO } \\
(\%)\end{array}$ & $\begin{array}{l}\text { SANTANDER } \\
(\%)\end{array}$ \\
\hline Adicional de Horas Extras & $2,1 \%$ & $2,68 \%$ & $5,87 \%$ & $1,09 \%$ & $2,37 \%$ \\
Adicional de Insalubridade / Periculosidade & $0,6 \%$ & $2,15 \%$ & $1,09 \%$ & $1,09 \%$ & $2,09 \%$ \\
Doença Profissional & $0,8 \%$ & $0,36 \%$ & $0,13 \%$ & $3,27 \%$ & $1,12 \%$ \\
Horas Extras & $29,5 \%$ & $36,85 \%$ & $31,60 \%$ & $40,29 \%$ & $32,68 \%$ \\
Indenizações / Assédio Moral & $5,9 \%$ & $6,98 \%$ & $4,00 \%$ & $9,62 \%$ & $7,96 \%$ \\
Reflexos / Horas Extras & $7,0 \%$ & $12,97 \%$ & $7,73 \%$ & $6,53 \%$ & $5,73 \%$ \\
\hline
\end{tabular}

Quanto à polivalência do bancário, a Febraban ainda declara que existe uma forte tendência de algumas funções serem extintas, como a dos caixas, com o avanço das tecnologias. Como é uma função que lida diretamente com os clientes, caso a função se extingue e o colaborador passe para a função de agente ou comercial, as chances dele conhecer as demandas dos clientes são altas. Esse conhecimento pode colaborar para sua sucessão na empresa, já que muitos gerentes de contas (90\%) vieram da função de caixa. Ou 
seja, para a Febraban não adianta lutar contra o novo perfil profissional nem contra a tecnologia e seus avanços, as mudanças são contínuas e gradativas.

Em geral, os bancos tem proporcionado iniciativas para a prevenção de acidentes de trabalho, para a promoção da qualidade de vida, porém, mesmo com o acordo de combate ao assédio moral entre o Sindicato e os bancos, as iniciativas frente a esse aspecto não foram relatadas. Esse acordo implica em meios para as pessoas denunciarem se algo não está de acordo no ambiente de trabalho, e para que haja resolução de conflitos o banco tem até 45 dias para tomar medidas, caso contrário, as ações sindicais entram em vigor. Para o Sindicato o assédio moral ocorre pois existem muitas metas e muitas cobranças nos bancos.

A Febraban corrobora a iniciativa do sistema de denúncia de conflitos no ambiente de trabalho, alegando que todo banco precisa ter dois canais seguros para os colaboradores se pronunciarem, tanto internamente, quanto com o Sindicato. Esse meio possibilita a resolução dos problemas, por meio de novas políticas de treinamento de gestores e liderança, para que esses comportamentos sejam evitados. O Itaú Unibanco foi o único a mencionar o compromisso de combater o assédio moral, mas não reportou quais iniciativas toma para ter sucesso nesse comprometimento.

Esse sistema de alimentação e retroalimentação, permite que a cada semestre as denúncias recebidas sejam analisadas, e ações para corrigir esses comportamentos em geral, são tomadas. A Febraban ainda informa que nas políticas dos bancos está claro a não aceitação de assédio moral, sexual, discriminação, inclusive nos treinamentos já começaram a ser desenvolvidas iniciativas nesses aspectos, mas não houve mensuração dos resultados.

Apesar dessas iniciativas, ainda existem dados de Síndrome do Pânico, depressão, LER/DORT (Lesão por Esforço Repetitivo/ Doenças Osteoarticulares Relacionadas ao Trabalho), tendinite, que o Sindicato alega serem advindos da exploração dos clientes e dos funcionários. Ao mesmo tempo que esses treinamentos são proporcionados para modificar os comportamentos dos gestores, existem reuniões sobre as metas que devem ser alcançadas. Se houvesse uma maior contratação de pessoas, os funcionários seriam capazes de trabalhar com mais tranquilidade, atendendo melhor seus clientes, melhorar suas estratégias para alcançar suas metas.

Os colaboradores além de vender os produtos, devem prestar atenção se não existem erros, não há lavagem de dinheiro, e nenhuma operação ilegal, ao mesmo tempo que atendem os clientes, ou seja, ficam sobrecarregados.

Para a Febraban, as normas dos bancos são decorrentes dos controles que devem ser extremamente sofisticados para cuidar dos ativos de terceiros. Para evitar a perda para os 
clientes, o cuidado com um padrão muito bem estabelecido é necessário. Ademais, a Febraban declara que o que os bancos faziam de errado em relação aos bancários, vem sendo corrigido ao longo do tempo, como a LER que tem uma curva descendente e se não tivesse tido uma redução progressiva, hoje haveria uma epidemia da doença.

As pessoas acabam recebendo mais pressão do que deveriam, não pela organização do trabalho, mas por sua chefia imediata. Apesar disso influenciar nos distúrbios psicológicos e de comportamento, elas vem sendo mapeadas pelo setor. A Febraban afirma que mesmo com políticas proativas neste campo, como as regras de que os rankings de funcionários são proibidos, não podem expor os funcionários, entre outras, sempre tem alguém que as viola. Para isso, alguns mecanismos de vigilância são necessários, como a oportunidade dos colaboradores se pronunciarem.

As queixas trabalhistas recebidas pelos bancos foram relatadas apenas pelo Itaú Unibanco e pelo Bradesco. Uma outra forma mapear as ocorrências seria sugerir que não apenas o número de ocorrências fossem reportados, mas os tipos, facilitando no delineamento de ações para essas questões.

Dentro das queixas trabalhistas analisadas nos acórdãos, todos os bancos apresentaram o maior índice relativo às horas extras e seus reflexos. As explicações do Sindicato e da Febraban se divergem nesse aspecto.

Para o Sindicato, na década de 80 a figura do falso-comissionado foi criada, com a pessoa trabalhando mais tempo. A reivindicação do Sindicato nessa época era de que as jornadas de trabalho fossem de 5 horas, contratando mais pessoas, atendendo melhor os clientes consequentemente e mudando a classificação de risco dos bancários no INSS (Instituto Nacional do Seguro Social), pois o risco é mais alto que de policiais e professores.

A intenção dos bancos era das jornadas de 8 horas diárias, porém, não houve acordo para essa mudança. Os chefes foram promovidos e recebem, $55 \%$ a mais, podendo trabalhar as 8 horas com mais duas horas extras por dia. Com o passar dos anos, os bancos perceberam que essa era uma maneira de fazer os funcionários trabalharem mais, então começaram a promove-los, sem possuírem subordinados, e sem autonomia para tomar decisões que cabem à Alta Administração.

Essa questão passou a ser alvo dos advogados, já que se não possuíam subordinados, nem tinham autonomia para admitir ou demitir funcionários, eles são considerados falsocomissionados. As ações pautadas nessas demandas são causas ganhas, e por isso que os bancos tentam fazer modificações na legislação, para desregulamentar ou terceirizar profissionais. Apesar disso, para o Sindicato a questão das metas é muito mais danosa que das 
horas extras, pois a obrigação de cumpri-las independe das 6 ou das 8 horas diárias de trabalho.

A Febraban explica essa questão das horas extras de outra maneira. A jornada de trabalho dos bancários de 6 horas advém de um decreto em 1933, da época de Getúlio Vargas. Nessa época, o bancário realizava o trabalho de banco, e não tinha nenhuma habilidade específica que não fosse proporcionada pelo banco. Com o passar dos anos, as instituições financeiras começaram a apresentar as mesmas atividades existentes na indústria e no comércio, com engenheiros, psicólogos, programadores de software, etc.

Desse modo, como agir com esses colaboradores com outras especialidades, que fariam a mesma função do banco em outros setores da economia, nas 8 horas diárias, se a oferta de uma remuneração proporcional à 6 horas eles não costumam aceitar. Essa discussão envolvendo saúde dos colaboradores, metas, ambiente de trabalho são recorrentes entre Febraban e Sindicato.

Ao investir na estratégia de contratar os colaboradores com uma jornada de 8 horas diárias, eles assinam um contrato condizente com o que o banco vai proporcionar, porém quando demitido recorre à justiça reclamando das duas horas extras. $\mathrm{O}$ acordo é difícil de ser realizado para modificar essa situação, principalmente na justiça do trabalho que defende o hipossuficiente ${ }^{4}$.

Os impasses na questão da saúde enfrentadas pelo setor bancário acabam mascarando a defesa da jornada de 6 horas diárias de trabalho, mas isso não implica na não realização de projetos na saúde motivacional dos colaboradores. A Febraban afirma que uma empresa de consultoria foi contratada para implantar melhorias na saúde e segurança dos grandes bancos, onde estão concentradas a maior parte da mão de obra.

Mesmo com a crítica envolvendo que essas ações são apresentadas mais como reputação organizacional e reforço da imagem, não demonstrando uma preocupação real com seu público interno e sim com um ganho unilateral (ANDRADE et al., 2011), o setor bancário vem mapeando os problemas com seus colaboradores, e gradativamente realizando modificações.

A Tabela 43 a seguir mostra uma comparação em termos das queixas trabalhistas e suas recorrências.

\footnotetext{
${ }^{44}$ Concessão da gratuidade da justiça para os que alegam pobreza no sentido técnico.
} 
Tabela 43. Comparativo de recorrência das queixas trabalhistas

\begin{tabular}{|c|c|c|c|c|c|}
\hline $\begin{array}{l}\text { TIPOS DE } \\
\text { QUEIXAS } \\
\text { TRABALHISTAS }\end{array}$ & $\begin{array}{l}\text { BANCO DO } \\
\text { BRASIL }\end{array}$ & BRADESCO & SANTANDER & CEF & ITAÚ \\
\hline Acúmulo de Função & $0,53 \%$ & $1,27 \%$ & $1,26 \%$ & $0,80 \%$ & $1,07 \%$ \\
\hline $\begin{array}{l}\text { Adicional de Horas } \\
\text { Extras }\end{array}$ & $2,11 \%$ & $1,09 \%$ & $2,37 \%$ & $5,87 \%$ & $2,68 \%$ \\
\hline $\begin{array}{l}\text { Adicional de } \\
\text { Insalubridade / } \\
\text { Periculosidade }\end{array}$ & $0,63 \%$ & $1,09 \%$ & $2,09 \%$ & $0,80 \%$ & $2,15 \%$ \\
\hline $\begin{array}{l}\text { Adicional de } \\
\text { Transferência }\end{array}$ & $0,21 \%$ & $0,36 \%$ & $0,00 \%$ & $0,13 \%$ & $0,09 \%$ \\
\hline Adicional Noturno & $0,63 \%$ & $0,36 \%$ & $0,84 \%$ & $0,13 \%$ & $0,81 \%$ \\
\hline Ausências Permitidas & $0,11 \%$ & $0,00 \%$ & $0,00 \%$ & $0,00 \%$ & $0,00 \%$ \\
\hline Auxílios & $7,80 \%$ & $4,17 \%$ & $4,47 \%$ & $12,13 \%$ & $3,58 \%$ \\
\hline $\begin{array}{l}\text { Base de Cálculo das } \\
\text { Horas Extras }\end{array}$ & $1,37 \%$ & $0,36 \%$ & $2,23 \%$ & $3,07 \%$ & $1,97 \%$ \\
\hline Comissões & $0,74 \%$ & $0,73 \%$ & $2,51 \%$ & $2,40 \%$ & $2,68 \%$ \\
\hline $\begin{array}{l}\text { Complementação de } \\
\text { Aposentadoria }\end{array}$ & $2,42 \%$ & $0,00 \%$ & $0,84 \%$ & $1,07 \%$ & $0,00 \%$ \\
\hline $\begin{array}{l}\text { Contribuições } \\
\text { Assistenciais } \\
\text { Contribuicões }\end{array}$ & $0,21 \%$ & $0,18 \%$ & $0,70 \%$ & $0,13 \%$ & $0,09 \%$ \\
\hline $\begin{array}{l}\text { Previdenciárias e } \\
\text { Fiscais / IR - Juros }\end{array}$ & $6,22 \%$ & $5,44 \%$ & $4,05 \%$ & $2,53 \%$ & $3,31 \%$ \\
\hline $\begin{array}{l}\text { Depósitos de FGTS } \\
\text { Devolução de }\end{array}$ & $0,32 \%$ & $0,00 \%$ & $0,28 \%$ & $0,40 \%$ & $0,00 \%$ \\
\hline $\begin{array}{l}\text { Descontos / Dedução } \\
\text { de Valores }\end{array}$ & $1,16 \%$ & $0,73 \%$ & $1,12 \%$ & $1,33 \%$ & $0,81 \%$ \\
\hline $\begin{array}{l}\text { Diferenças de FGTS } \\
+40 \%\end{array}$ & $1,79 \%$ & $0,18 \%$ & $0,84 \%$ & $0,67 \%$ & $0,45 \%$ \\
\hline Diferenças Salariais & $5,16 \%$ & $5,26 \%$ & $4,05 \%$ & $7,60 \%$ & $0,81 \%$ \\
\hline Doença Profissional & $0,84 \%$ & $3,27 \%$ & $1,12 \%$ & $0,13 \%$ & $0,36 \%$ \\
\hline $\begin{array}{l}\text { Enquadramento } \\
\text { Sindical }\end{array}$ & $0,21 \%$ & $0,36 \%$ & $0,84 \%$ & $0,13 \%$ & $0,18 \%$ \\
\hline Equiparação Salarial & $1,48 \%$ & $2,54 \%$ & $4,75 \%$ & $0,53 \%$ & $5,64 \%$ \\
\hline $\begin{array}{l}\text { Estabilidade } \\
\text { Provisória }\end{array}$ & $1,16 \%$ & $1,09 \%$ & $0,56 \%$ & $0,00 \%$ & $0,00 \%$ \\
\hline Férias & $1,48 \%$ & $0,91 \%$ & $1,82 \%$ & $1,20 \%$ & $1,52 \%$ \\
\hline $\begin{array}{l}\text { FGTS - Incidências } \\
\text { sobre Comissões }\end{array}$ & $0,11 \%$ & $0,00 \%$ & $0,00 \%$ & $0,67 \%$ & $0,00 \%$ \\
\hline $\begin{array}{l}\text { Frequência Livre / } \\
\text { Dirigente Sindical }\end{array}$ & $0,11 \%$ & $0,00 \%$ & $0,00 \%$ & $0,00 \%$ & $0,00 \%$ \\
\hline $\begin{array}{l}\text { Gratificação de } \\
\text { Função }\end{array}$ & $1,16 \%$ & $0,36 \%$ & $0,56 \%$ & $3,47 \%$ & $0,63 \%$ \\
\hline Horas de Sobreaviso & $2,53 \%$ & $0,73 \%$ & $1,40 \%$ & $0,13 \%$ & $0,45 \%$ \\
\hline Horas Extras & $29,50 \%$ & $40,29 \%$ & $32,68 \%$ & $31,60 \%$ & $36,85 \%$ \\
\hline Indenizações & $5,90 \%$ & $9,62 \%$ & $7,96 \%$ & $4,00 \%$ & $6,98 \%$ \\
\hline $\begin{array}{l}\text { INSS / Assistência } \\
\text { Médica / Plano de } \\
\text { Saúde }\end{array}$ & $0,95 \%$ & $0,91 \%$ & $0,14 \%$ & $0,00 \%$ & $0,36 \%$ \\
\hline Jornada de Trabalho & $1,48 \%$ & $2,54 \%$ & $2,51 \%$ & $6,27 \%$ & $3,58 \%$ \\
\hline $\begin{array}{l}\text { Justa Causa } \\
\text { Multas }\end{array}$ & $0,11 \%$ & $0,00 \%$ & $0,56 \%$ & $0,40 \%$ & $1,07 \%$ \\
\hline $\begin{array}{l}\text { Convencionais / } \\
\text { Normativas }\end{array}$ & $1,58 \%$ & $3,45 \%$ & $3,77 \%$ & $0,40 \%$ & $2,15 \%$ \\
\hline
\end{tabular}




\begin{tabular}{|c|c|c|c|c|c|}
\hline $\begin{array}{l}\text { TIPOS DE } \\
\text { QUEIXAS } \\
\text { TRABALHISTAS } \\
\end{array}$ & $\begin{array}{l}\text { BANCO DO } \\
\text { BRASIL }\end{array}$ & BRADESCO & SANTANDER & CEF & ITAÚ \\
\hline $\begin{array}{l}\text { Multas Rescisórias } \\
\text { Participação no }\end{array}$ & $2,42 \%$ & $0,91 \%$ & $0,98 \%$ & $1,20 \%$ & $1,34 \%$ \\
\hline $\begin{array}{l}\text { Lucros e Resultados } \\
\text { (PLR) }\end{array}$ & $2,42 \%$ & $2,36 \%$ & $2,51 \%$ & $0,27 \%$ & $3,04 \%$ \\
\hline $\begin{array}{l}\text { Plano de Demissão } \\
\text { Voluntária (PDV) }\end{array}$ & $0,95 \%$ & $0,00 \%$ & $0,42 \%$ & $0,00 \%$ & $0,00 \%$ \\
\hline $\begin{array}{l}\text { Quilômetros } \\
\text { Rodados }\end{array}$ & $0,63 \%$ & $0,73 \%$ & $1,82 \%$ & $1,33 \%$ & $0,72 \%$ \\
\hline Reajustes Salariais & $1,37 \%$ & $0,00 \%$ & $0,28 \%$ & $0,67 \%$ & $0,00 \%$ \\
\hline $\begin{array}{l}\text { Rescisão Contratual / } \\
\text { PDV }\end{array}$ & $0,21 \%$ & $0,00 \%$ & $0,00 \%$ & $0,27 \%$ & $0,89 \%$ \\
\hline $\begin{array}{l}\text { Redução Salarial } \\
\text { Reembolso com }\end{array}$ & $1,69 \%$ & $0,00 \%$ & $0,00 \%$ & $0,40 \%$ & $0,09 \%$ \\
\hline $\begin{array}{l}\text { Requalificação } \\
\text { Especial }\end{array}$ & $0,21 \%$ & $0,00 \%$ & $0,28 \%$ & $0,00 \%$ & $0,00 \%$ \\
\hline $\begin{array}{l}\text { Reflexos / Horas } \\
\text { Extras }\end{array}$ & $6,95 \%$ & $6,53 \%$ & $5,73 \%$ & $7,73 \%$ & $12,97 \%$ \\
\hline Retificação da CTPS & $0,63 \%$ & $0,73 \%$ & $0,14 \%$ & $0,00 \%$ & $0,09 \%$ \\
\hline $\begin{array}{l}\text { Reversão de Pedido } \\
\text { de Demissão }\end{array}$ & $0,11 \%$ & $0,00 \%$ & $0,00 \%$ & $0,00 \%$ & $0,00 \%$ \\
\hline $\begin{array}{l}\text { Unicidade Contratual } \\
\text { Verbas Rescisórias }\end{array}$ & $0,11 \%$ & $0,00 \%$ & $0,00 \%$ & $0,00 \%$ & $0,00 \%$ \\
\hline $\begin{array}{l}\text { Base de Cálculo } \\
\text { Salarial }\end{array}$ & $0,21 \%$ & $0,00 \%$ & $0,56 \%$ & $0,13 \%$ & $0,00 \%$ \\
\hline $\begin{array}{l}\text { Vínculo } \\
\text { Empregatício / } \\
\text { Condição de } \\
\text { Bancário }\end{array}$ & $2,11 \%$ & $1,45 \%$ & $0,98 \%$ & $0,00 \%$ & $0,63 \%$ \\
\hline $\begin{array}{l}\text { TOTAL DE } \\
\text { CAUSAS } \\
\end{array}$ & $100 \%$ & $100 \%$ & $100 \%$ & $100 \%$ & $100 \%$ \\
\hline
\end{tabular}

Diante do exposto, é possível observar o que já foi supracitado: de que as horas extras apresentam o maior número de reclamações nos bancos. Além disso, é possível analisar as outras categorias, como de indenizações, diferenças salariais, auxílios, que se destacam na figura.

Assim, a proposição $2(\mathrm{P} 2)$, de que o desequilíbrio entre a vida profissional e a vida pessoal resultam em queixas trabalhistas é confirmada. No caso do setor bancário, a maior recorrência é nas horas extras e seus reflexos, e em grande parte acontece pela legislação das 30 horas semanais de jornada de trabalho do bancário, como explicitada anteriormente. Como o setor tem as 30 horas na lei, é uma conquista desses trabalhadores, e os bancos não tem respeitado essa questão como deveria. A segunda maior recorrência é relativa à assédio moral, e não de que as queixas advém do desequilíbrio entre a vida profissional e pessoal. 


\subsection{DESAFIOS E METAS PARA OS PRÓXIMOS ANOS}

Condizente com o mapeamento dos problemas e o planejamento das modificações que os bancos tem demonstrado esforços para realizar, as metas e desafios pautados na sustentabilidade são descritas a seguir por banco.

\subsubsection{BANCO DO BRASIL}

O Banco do Brasil, após o engajamento dos seus stakeholders na definição de suas metas para o biênio, levantou alguns pontos a serem aprimorados na Dimensão Social, Ambiental e Econômico.

O relatório anual do Banco do Brasil (2013, p. 16) traz as seguintes intenções:

- Aprimorar a relação entre o Investimento Social Privado (ISP) e a estratégia de negócios.

- Aprimorar o posicionamento do Banco frente aos assuntos polêmicos e dilemas relacionados aos empréstimos e investimentos.

- Reforçar a gestão do conhecimento, minimizando os impactos decorrentes de transferências e desligamentos de funcionários.

- Reforçar programas internos de educação e sensibilização para a sustentabilidade.

- Aprimorar o sistema de remuneração variável dos funcionários, inclusive Diretoria Executiva, contemplando o desempenho individual.

- $\quad$ Aumentar o índice de satisfação dos funcionários.

- Aprimorar a gestão de Saúde e Segurança Ocupacional - SSO (sistema, indicadores, metas, mapa de risco, transparência, capacitação etc.).

- Manter e expandir o papel do Banco como um agente indutor do desenvolvimento sustentável por meio da inclusão financeira e dos negócios sociais (Microcrédito Produtivo Orientado - MPO, Programa de Financiamento Estudantil - Fies, Minha Casa Minha Vida - MCMV e BB Crédito Acessibilidade, entre outros), integrando programas e políticas públicas, parcerias com o setor privado e estratégias de desenvolvimento sustentável do BB (investimento social privado, voluntariado, inclusão digital e desenvolvimento regional sustentável).

- Desdobrar a representatividade de gênero do quadro de pessoal nos cargos de gestão em todos os níveis hierárquicos da Organização. 
O Banco do Brasil detectou as melhorias que precisa fazer condizentes com as sugestões da GSP. Um acompanhamento para verificar se essas ações de fato foram colocadas em práticas fica de sugestão para próximos estudos.

\subsubsection{ITAÚ-UNIBANCO}

O Banco Itaú Unibanco, apesar de não apresentar todas as dimensões do triple bottom line descritas em todas as práticas de gestão de pessoas reportadas, demonstra ações e iniciativas com intuito de atender as demandas dos stakeholders. Os desafios compilados para os próximos passos da organização frente às diretrizes da sustentabilidade organizacional foram (Relatório Anual, 2013, p. A-340):

- Melhorar os aspectos de integração social, ambiental e governança nas linhas de negócios do banco;

- Avaliar oportunidades de negócios sociais e ambientais;

- Facilitar a transferência de capacidade e de conhecimento social e ambiental entre as áreas de negócios.

Um outro aspecto encontrado é o desafio de amenizar as reclamações frente às horas extras e seus reflexos, que podem refletir na saúde, segurança e qualidade de vida dos colaboradores.

O Itaú Unibanco se destacou no reporte de suas iniciativas, sendo a riqueza de detalhes de suas ações presente em todos os subsistemas de gestão de pessoas analisados nesse trabalho. Seus desafios demonstram seu alinhamento com o TBL e consequentemente com a GSP, já que suas ações visam cada vez mais incluir o tripé da sustentabilidade nelas.

\subsubsection{CAIXA ECONÔMICA FEDERAL}

Dentro das diretrizes da GSP a CEF ainda precisa fazer muitas implementações. Dentre as metas e compromissos elencados pela instituição, as que envolvem sustentabilidade são:

- Consolidar um programa geral de engajamento de fornecedores, conforme previsto no Plano de Compras Sustentáveis;

- Adequar os produtos e serviços já existentes ou desenvolver novos, com viés socioambiental;

- Implementar primeiro ciclo da sistemática de avaliação de desempenho para empregados da CAIXA; 
- Incluir no Edital do próximo concurso conteúdos do Código de Conduta dos Empregados CAIXA.

A CEF foi a única instituição a apresentar um relatório apenas de sustentabilidade e não o anual. Dentro de seus reportes muitos itens sugeridos pela GSP não foram englobados, como: número de queixas trabalhistas e seus tipos, iniciativas contra o assédio moral.

Os subsistemas de SPR e GDA não apresentaram quase nenhuma informação a respeito das ações aplicadas na organização. E nas metas para os próximos anos não foram encontradas informações que retratem mudanças nesses quesitos.

Ainda, nos aspectos da diversidade, a CEF precisa melhorar os índices de pessoas com necessidades especiais e o equilíbrio de gênero na composição do quadro de funcionários. Itens também não contemplados nas metas e compromissos para os próximos anos.

A avaliação de desempenho que a CEF não realiza ainda, foi o único item sugerido pela GSP encontrado nas metas e desafios do próximo ano.

\subsubsection{BRADESCO}

As ações do Bradesco frente às práticas adotadas pela área de gestão de pessoas são trazidas no relatório anual como iniciativas a partir de 2012, ou seja, muito recente para seus resultados serem analisados.

As metas traçadas para os próximos anos estão pautadas na continuidade de implementação do mapeamento de competências e da estimativa de entrega, para desenvolver o capital humano, e a colaboração da UniBrad para incrementar essa iniciativa. Outra meta é continuar nos rankings de clima organizacional, e por último, expandir a implementação do Sistema de Gestão de Saúde e Segurança do Trabalho, conforme as normas SA8000.

Aproveitando a intenção de melhorias nas áreas organizacionais relativas às pessoas, $\mathrm{o}$ Bradesco poderia adotar as sugestões da GSP para desenhar suas ações e iniciativas pautadas no TBL.

Nos acórdãos trabalhistas o Bradesco apresentou os índices mais altos de indenizações por assédio moral, e não possui programa de combate ao assédio. Os subsistemas de SPR e GDA também não apresentaram muitas informações. Nas práticas de T\&D também apresentam poucos treinamentos e mais relativos aos públicos externos que aos colaboradores. Além disso, precisa aumentar seus índices de pessoas portadoras de necessidades especiais na composição de seu quadro de funcionários.

Ao longo da sua história, diversas iniciativas demonstraram que a instituição se preocupa com esses temas, como a adesão ao Pacto Global, Princípios do Equador, a 
integração ao ISE - Índice de Sustentabilidade Empresarial, da Bovespa e o Índice Down Jones de Sustentabilidade, além de parcerias como a do Governo do Amazonas, que culminou na Fundação Amazonas Sustentável, preservando a Floresta Amazônica e contribuindo para o desenvolvimento da região, entre outras.

Pela análise das práticas, os conceitos do TBL deveriam estar mais incorporados nos públicos internos do Bradesco, o que um alinhamento da GSP à essas atividades contribuiria para gerar mais valor e competitividade ao Bradesco.

\subsubsection{SANTANDER}

O Santander alega que a sustentabilidade faz parte de sua estratégia de negócio. A partir dos três eixos de atuação - Inclusão Social e Financeira, Educação e Negócios Socioambientais, algumas metas foram traçadas para o próximo ano do banco.

De todas as metas traçadas, a maioria visa impactar o ambiente e público externo à organização com as ações em sustentabilidade, como a redução do consumo de energia e da emissão de gases do efeito estufa em $20 \%$; treinar funcionários para realizarem análises de risco de crédito e atendimento ao cliente; concessão de bolsas de estudos para estudantes universitários e professores, ou seja, metas que visam impactar a sociedade positivamente, e o reconhecimento de boas práticas em negócios sustentáveis.

Para o público interno os desafios são pautados em mobilizar $20 \%$ do quadro de colaboradores a participarem do Sustentabilidade para Todo Lado, e implementar o Programa Corporativo Anticorrupção que visa treinar todos funcionários.

Além dessas metas elencadas pelo Santander e seu programa de Pesquisa de Engajamento dos funcionários, a área de gestão de pessoas ainda precisa incorporar mais ações e estratégias que alinhem a sustentabilidade ao público interno.

A limitação dessa análise ocorre por falta de informações fornecidas pelo Santander em seu relatório anual frente a gestão de desempenho, aos programas de remuneração e benefícios, dados sobre saúde, segurança e qualidade de vida no trabalho.

Porém, como foi relatado que a Governança da Sustentabilidade segue as diretrizes do Comitê Global de Sustentabilidade do Grupo Santander, presidido pelo CEO do grupo e conta com todas as áreas do negócio, a definição das estratégias, políticas e ações que impulsionem formar e sensibilizar as pessoas frente às diretrizes socioambientais, se torna uma grande oportunidade de implementar a GSP. 


\subsubsection{SÍNTESE DAS METAS E DESAFIOS}

O Quadro 24 a seguir apresenta a síntese das iniciativas elencadas como metas e desafios para os próximos anos nos bancos.

Quadro 24. Metas e desafios para os próximos anos nos bancos

\begin{tabular}{|c|c|c|c|c|c|}
\hline Metas e Desafios & $\begin{array}{l}\text { Banco do } \\
\text { Brasil }\end{array}$ & Itaú Unibanco & $\begin{array}{l}\text { Caixa } \\
\text { Econômica } \\
\text { Federal }\end{array}$ & Bradesco & Santander \\
\hline $\begin{array}{l}\text { Desenvolver e/ou } \\
\text { aprimorar programas } \\
\text { de educação e } \\
\text { sensibilização em } \\
\text { sustentabilidade }\end{array}$ & Sim & Sim & Sim & Sim & Sim \\
\hline $\begin{array}{l}\text { Incluir remuneração } \\
\text { variável em seu } \\
\text { sistema }\end{array}$ & Sim & Já possui. & Não informado & Não informado & Não informado \\
\hline $\begin{array}{l}\text { Aprimorar a Gestão } \\
\text { da Saúde e } \\
\text { Segurança } \\
\text { Ocupacional }\end{array}$ & Sim & Não informado. & Não informado & Sim & Não informado \\
\hline $\begin{array}{l}\text { Manter e/ou induzir } \\
\text { o papel de agente } \\
\text { do desenvolvimento } \\
\text { sustentável }\end{array}$ & Sim & Sim & Não informado & Sim & Sim \\
\hline $\begin{array}{l}\text { Equalizar as } \\
\text { remunerações por } \\
\text { gênero }\end{array}$ & Não informado & Não informado & Não informado & Não informado & Não informado \\
\hline $\begin{array}{l}\text { Incluir as avaliações } \\
\text { de desempenho } \\
\text { individuais para } \\
\text { todos os } \\
\text { colaboradores }\end{array}$ & Não informado & Já possui. & Sim & Sim & Não informado \\
\hline $\begin{array}{l}\text { Intenção de } \\
\text { minimizar as queixas } \\
\text { trabalhistas }\end{array}$ & Não informado & Sim & Não informado & Não informado & Não informado \\
\hline $\begin{array}{l}\text { Desafio de combater } \\
\text { o assédio moral }\end{array}$ & Não informado & Sim & Não informado & Não informado & Não informado \\
\hline
\end{tabular}

Fonte: Elaborado pela autora.

As ações dos bancos em geral, podem ser examinadas sob algumas perspectivas. Para o Sindicato dos Bancários, alegar que os bancos são sustentáveis como em seus manuais, nas propagandas, é uma realidade distante do que eles fazem. A natureza deles, seus negócios e suas estratégias para vender produtos e terem lucro, não condizem com uma responsabilidade pautada nos aspectos ambientais, sociais, mas apenas no econômico.

Para a Febraban a conscientização das questões envolvendo a sustentabilidade está ocorrendo não apenas no setor bancário, como nas outras organizações. Como o setor 
bancário é pulverizado e está presente em mais de 4 mil municípios, exige um modelo de gestão extremamente avançado, no sentido de captar as necessidades, levantar as informações, e proporcionar as capacitações.

Como o banco trabalha com recursos de terceiros, objetivando rentabilizar a poupança da sociedade e financiando o desenvolvimento do país, controlar as suas ações é necessário para mapear os problemas e proporcionar as devidas melhorias.

A crescente concorrência mundial requer um desenvolvimento do potencial interno das organizações, já que são as pessoas que mantêm o sistema administrativo em operação. Dessa forma desenvolver um sistema de gestão de pessoas capaz de sensibilizar a todos, pode ser visto como vital no alcance da vantagem competitiva (SAVANEVICIEN E STANKEVICIUTE, 2012).

Desse modo, com a identificação e intenção de melhorias em alguns aspectos organizacionais, elencados como desafios para os bancos, apresenta a crescente consciência pública sobre a importância das organizações na contribuição para o desenvolvimento sustentável (EHNERT et al., 2015).

Logo, a proposição 3 (P3) de que setor bancário brasileiro tem integrado a sustentabilidade em suas ações de gestão de pessoas é verificada.

\subsection{GESTÃO SUSTENTÁVEL DE PESSOAS NOS BANCOS BRASILEIROS}

A utilização da metodologia sistêmica, desenvolvida por Checkland (1981), permite avançar na exploração da Gestão Sustentável de Pessoas.

\section{Etapa 1: Situação problemática não estruturada}

A análise das práticas de gestão de pessoas do setor bancário brasileiro nos âmbitos social, ambiental e econômico revelou que frente à Gestão Sustentável de Pessoas existem algumas lacunas. Integrar a sustentabilidade organizacional à área de gestão de pessoas, gerindo as organizações em relação aos seus recursos humano-sociais, naturais e econômicos é um grande desafio (EHNERT e HARRY, 2012).

Considerando a visão sistêmica dos negócios, essa lacuna se pauta na distância entre o conceito de sustentabilidade organizacional e as estratégias adotadas para que ela seja implementada no dia-a-dia das operações, agravada pelo fato de não existir um modelo 
conceitual capaz de retratar as ações que a Gestão Sustentável de Pessoas sugere (CHENG et al., 2010).

Embora os estudos nessa linha tenham crescido, mais pesquisas são necessárias para dar forma ao conceito, desenvolvendo um guia de implicações práticas que sejam claras e objetivas para serem seguidas, ou seja, os trabalhos tem sido mais conceituais e menos de natureza exploratória (EHNERT et al., 2015).

Modelos de gestão de pessoas emergentes surgiram ao longo dos anos. A Gestão Estratégica de Pessoas baseia-se na organização que apresenta a função de gestão de pessoas verticalmente alinhada com a missão e os objetivos organizacionais e horizontalmente integrada com as outras funções organizacionais (GREEN et al., 2006). Como observado nas análises das práticas de gestão de pessoas do setor bancário brasileiro, alinhar a sustentabilidade às estratégias organizacionais tem sido presente nos relatos.

Por outro lado, o Green Human Resources Management é outro modelo de gestão de pessoas emergente que aborda a importância de implementar e melhorar os enfoques e práticas da gestão ambiental nas organizações (JABBOUR et al., 2013). As discussões sobre as questões ambientais e as relações com ações empresariais foi iniciada na década de 1960, após algumas catástrofes ambientais terem ocorrido, principalmente por má administração das empresas. Tais fatores levaram a busca por soluções para modificar esse cenário (JUNQUEIRA et al., 2011).

No setor bancário a preocupação, investimento e sensibilização do aspecto ambiental é evidente, principalmente porque ao investir no desenvolvimento econômico de outras organizações, o risco ambiental afeta diretamente o retorno financeiro das mesmas, e indiretamente atinge os bancos (INFANTE et al., 2010). Por isso, muitas ações de treinamento, conscientização, comunicação da sustentabilidade podem ser observadas nas instituições bancárias.

O aspecto social pode ser dividido em duas partes: público externo, compreendendo as comunidades, e o público interno, que corresponde aos colaboradores. Andrade et al. (2011) alega que a preocupação com o público interno ainda é vista como reputação organizacional e reforço de imagem, visando um ganho unilateral. Os estudos de sustentabilidade nas organizações contemplam mais as ações externas, que visam o desenvolvimento das comunidades ao entorno dos negócios, do que propriamente a força de trabalho existente dentro das organizações. Apesar disso, analisando o setor bancário, iniciativas envolvendo o público interno foram encontradas, como a questão da diversidade, do oferecimento de bolsas de estudo aos colaboradores, treinamento e desenvolvimento, entre outras. 
As manifestações externas são mais fáceis de imitar pelos concorrentes, já as dinâmicas tácitas e causalmente ambíguas internas, os padrões de trabalho em equipe e a coordenação na elaboração de estratégias, são elementos diferenciadores e fornecem uma fonte de inovação competitiva sustentável (JAMALI et al., 2015).

Assim, a Gestão de Pessoas representa um importante papel para alinhar a sustentabilidade às ações internas da organização aumentando a competitividade. Por meio dos seus subsistemas poderá proporcionar apoio, tanto estratégico quanto operacional, integrando a área à sustentabilidade organizacional e produzindo resultados sinérgicos (JAMALI et al., 2015). Logo, definir as ações dos subsistemas de gestão de pessoas pode auxiliar as organizações a equilibrarem seus investimentos tanto no âmbito econômico, quanto no ambiental e social, de modo que esses aspectos integrem as estratégias e os objetivos da empresa.

Portanto, a situação-problema baseia-se na falta de um modelo integrado de Gestão Sustentável de Pessoas capaz de indicar práticas coerentes nos âmbitos do tripé da sustentabilidade (social, ambiental e econômico).

A Figura 6 a seguir simboliza a importância do papel da Gestão de Pessoas no âmbito social interno do tripé da sustentabilidade (TBL). Dos modelos da área encontrados, o Green $H R M$ é a proposta que melhor alinha a gestão de pessoas ao aspecto ambiental. Ainda sim, para resolver o problema de integrar o TBL à Gestão de Pessoas, uma nova abordagem, envolvendo a Gestão Estratégica de Pessoas e os Subsistemas de Gestão de Pessoas, estabelecem as bases para a Gestão Sustentável de Pessoas. 
Figura 6. Importância do papel da Gestão de Pessoas no aspecto social interno

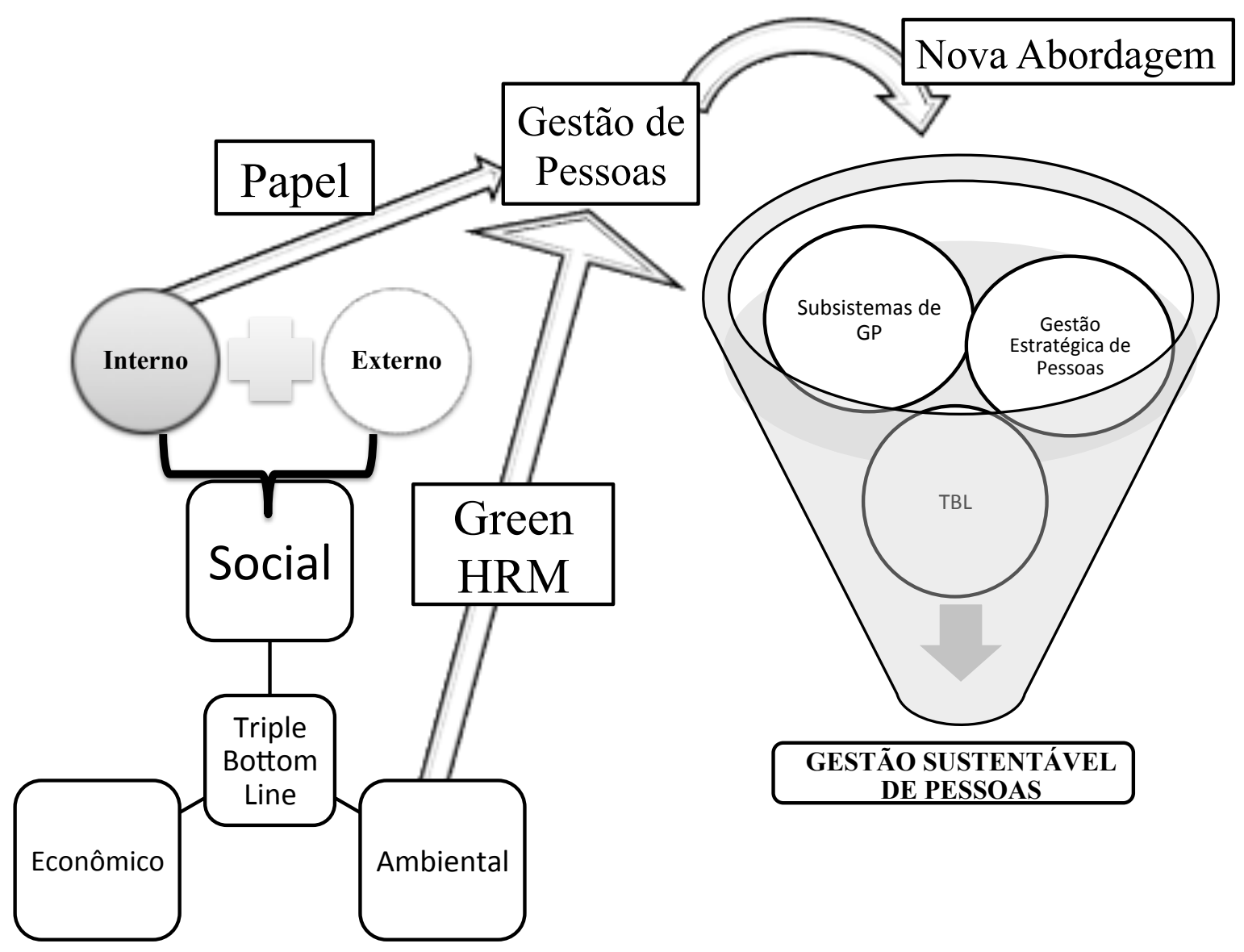

Fonte: Elaborado pela autora.

A figura parte do Triple Bottom Line, que abrange os âmbitos social, ambiental e econômico. $\mathrm{O}$ aspecto social é dividido entre social externo, abrangendo as comunidades e pessoas fora da organização, e, a social interna, condiz com os colaboradores da empresa.

A área de Gestão de Pessoas é a principal responsável por elaborar, definir e mapear novas ações envolvendo os três aspectos para os funcionários. Como o aspecto ambiental já possui diversos estudos com diretrizes envolvendo a gestão verde, denominado Green HRM, e o aspecto econômico que é a sustentabilidade financeira das organizações, e já está implícita em todas elas a busca pelo lucro, eficiência e permanência no mercado, uma nova abordagem é necessária para envolver o âmbito social.

Assim, alinhar a estratégia do setor bancário aos princípios do TBL e implantá-las em todos os subsistemas de Gestão de Pessoas, culminará na Gestão Sustentável de Pessoas, ou GSP. 
A integração do TBL nas ações organizacionais necessariamente passa pelos subsistemas de Gestão de Pessoas se o intento é dar suporte à novas demandas e no delineamento das novas formas de atuação. As organizações que querem atingir a sustentabilidade devem apresentar bons resultados em seus capitais econômico, social e ambiental - pilares inter-relacionados e que se influenciam mutuamente - enquanto contribuem para o desenvolvimento sustentável em seu domínio político (DYLLICK e HOCKERTS, 2002; CHENG et al., 2010).

As melhorias organizacionais devem integrar todas as atividades das empresas, não bastando apenas mudanças incrementais. Valente (2012) alega que a sustentabilidade necessita um novo modo de agir da organização e não apenas ser entendida como práticas isoladas voluntárias, ou respostas às exigências dos stakeholders. Ao olhar os paradoxos existentes entre os pilares da sustentabilidade defronta-se com a necessidade de partir para uma perspectiva a longo prazo, tanto na estratégia quanto na implementação desses conceitos nas ações organizacionais (EHNERT, 2009; COHEN et al., 2012).

Para Kramar (2014), a organização sustentável deve ter uma estrutura flexível com práticas de gestão de pessoas que constrói capacidades na força de trabalho; prevê a tomada de decisão participativa (empowerment), gestão da diversidade, níveis elevados de saúde no local de trabalho e indicadores de segurança e desempenho que refletem preocupações éticas e princípios da sustentabilidade.

Assim, a Figura 7 a seguir engloba o TBL dentro de cada subsistema de gestão de pessoas, e a Gestão Sustentável de Pessoas ainda contempla as ações desenvolvidas no Green $H R M$, e a importância de alinhar a Gestão Estratégica de Pessoas à esses conceitos. 


\section{Gestão Sustentável de Pessoas}

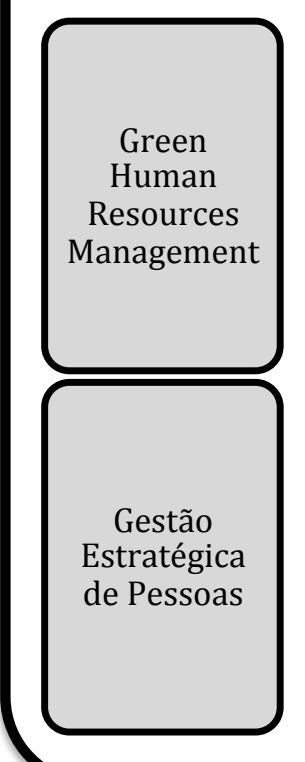

\section{Gestão de Pessoas}

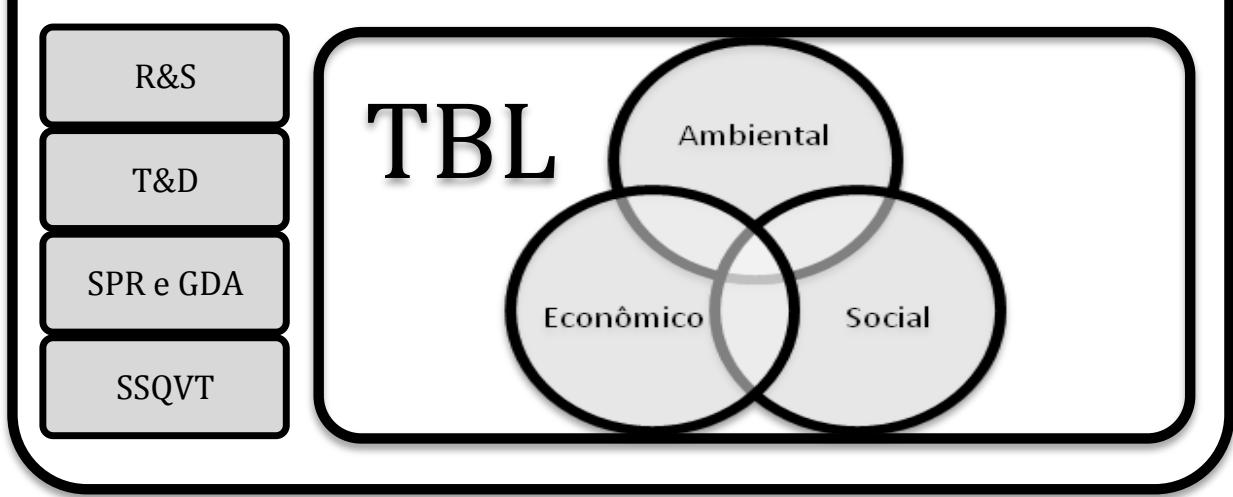

Fonte: Elaborado pela autora.

A Figura 7 representa a GSP. Junto às teorias de Gestão Estratégia de Pessoas e de Green HRM, a área de GP apresenta os cinco subsistemas - Recrutamento e Seleção, Treinamento e Desenvolvimento, Sistema de Pagamento e Recompensa, Gestão de Desempenho e Avaliação e Saúde, Segurança e Qualidade de Vida no Trabalho. Assim, o alinhamento entre os subsistemas e o TBL culminará na GSP. Tal alinhamento visa responder a problemática desta pesquisa, verificando a adesão do setor bancário brasileiro aos modelos de Gestão Sustentável de Pessoas.

\section{Etapa 3: Definições essenciais do Sistema Relevante}

Considerando o setor bancário brasileiro estudado neste trabalho, o checklist CATWOE foi utilizado para definir os sistemas relevantes.

O elemento central é a transformação ( $T$ ), que deve conter quais inputs são transformados em quais outputs, e como, sendo que as entradas representam a situação atual e as saídas a situação desejada. Os clientes (C), são todos aqueles beneficiários ou vítimas afetados pelas atividades do sistema. Os atores (A) são os agentes que realizam as principais atividades do sistema, especialmente o T. A visão de mundo (W) representa o panorama ou 
imagem que faz a definição raiz particularmente significante. $\mathrm{O}$ dono do sistema $(\mathrm{O})$ é quem tem a responsabilidade maior pelo mesmo e o poder para parar seu funcionamento. As restrições ambientais (E) são os elementos dos sistemas maiores que podem impedir ou prejudicar as atividades do sistema principal (Checkland, 1981, p. 224-225) .

\section{Quadro 25. Definições essenciais da SSM para Gestão Sustentável de Pessoas no Setor Bancário}

\begin{tabular}{|c|c|}
\hline \multicolumn{2}{|r|}{ DEFINIÇÕES ESSENCIAIS } \\
\hline C (Clientes - Customers) & $\begin{array}{l}\text { No caso do setor bancário, os maiores beneficiados serão os colaboradores das } \\
\text { instituições, focando o aspecto social interno. }\end{array}$ \\
\hline A (Atores - Actors) & $\begin{array}{l}\text { O processo deve ser desenhado pela área de Gestão de Pessoas em conjunto com } \\
\text { os integrantes do Alto Escalão das organizações. Aconselha-se que os } \\
\text { colaboradores, o Sindicato dos Bancários e a Febraban possam opinar a respeito } \\
\text { das decisões. Dentro dos atores, as competências para focarem no aspecto social } \\
\text { interno do setor já existem, apenas é necessário um planejamento de ações para } \\
\text { serem implementadas. }\end{array}$ \\
\hline $\begin{array}{l}\text { T (Transformação - } \\
\text { Transformation) }\end{array}$ & $\begin{array}{l}\text { O que se espera é que o foco dos investimentos das organizações do setor saíam } \\
\text { apenas do aspecto econômico, e consigam equilibrar suas ações tanto no meio } \\
\text { ambiente, quanto nos aspectos sociais internos e externos. Inputs: elaboração e } \\
\text { detalhamento das ações e alocação de recursos para efetivar a implantação das } \\
\text { ações. Outputs: o aspecto social interno considerado como importante para as } \\
\text { organizações, provendo saúde e qualidade de vida aos colaboradores. }\end{array}$ \\
\hline $\begin{array}{l}\text { W (Visão de Mundo - } \\
\text { Weltanschauung) }\end{array}$ & $\begin{array}{l}\text { O setor bancário brasileiro é um dos que mais lucram no país, sendo capazes de } \\
\text { investir no desenvolvimento sustentável, em contratar mais pessoas para diminuir } \\
\text { a sobrecarga dos seus atuais funcionários, e em promover saúde, segurança e } \\
\text { qualidade de vida a eles. Para promover mudanças, o setor é coeso, e a medida que } \\
\text { os problemas são identificados, as melhorias devem ser traçadas e implantadas. Há } \\
\text { necessidade do setor focar nessas mudanças. }\end{array}$ \\
\hline O (Donos - Owners) & $\begin{array}{l}\text { Os tomadores de decisão, que possuem autoridade e poder para serem } \\
\text { responsáveis pelo funcionamento e performance das ações a serem implementadas } \\
\text { são: Governo Federal, Acionistas, Empresários, gestores na área de Gestão de } \\
\text { Pessoas. }\end{array}$ \\
\hline $\begin{array}{l}\text { E (Ambiente - } \\
\text { Environment) }\end{array}$ & $\begin{array}{l}\text { Os bancos estão presentes em mais de } 4 \text { mil municípios, apresentando uma alta } \\
\text { capilaridade no país. Alinhar as ações de gestão de pessoas à todos os } \\
\text { funcionários, demandará tempo e encontrará resistências de algumas pessoas, pois } \\
\text { as percepções individuais são únicas de cada ser. Além disso, há a barreira dos } \\
\text { distintos interesses envolvidos entre os colaboradores internos e os bancários, que } \\
\text { podem restringir o bom funcionamento da implantação das ações. }\end{array}$ \\
\hline
\end{tabular}

Fonte: Elaborado pela autora.

\section{Etapa 4: Modelos Conceituais}

Essa etapa visa criar modelos de ações que podem resolver o problema em estudo. Num primeiro momento foi estabelecido quais subsistemas de gestão de pessoas seriam utilizados para delinear as ações. 
Após as análises realizadas no setor bancário, identificou-se que os subsistemas de Gestão de Avaliação e Desempenho, Envolvimento Empregatício, Empowerment e Engajamento e o Sistema de Pagamento e Recompensas estão interligados e interrelacionados. Os outros subsistemas foram selecionados como Recrutamento e Seleção, Treinamento e Desenvolvimento e Saúde, Segurança e Qualidade de Vida no Trabalho, classificações advindas e adaptadas dos autores Renwick et al. (2013), Kramar (2014), Greenwood (2012), Ehnert (2009) e Walton (1973). As ações foram delineadas a partir desses autores, e da Agenda de Trabalho Decente da OIT.

A Figura 8 a seguir retrata a configuração dos subsistemas de gestão de pessoas com essas aglutinações e classificações.

Figura 8. Subsistemas de Gestão de Pessoas

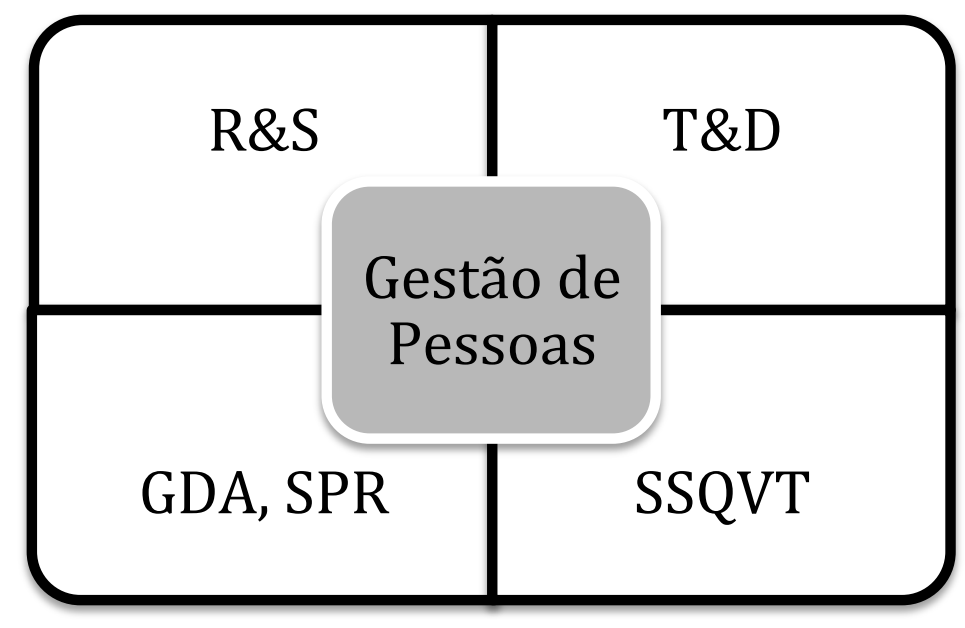

Fonte: Elaborado pela autora

Para cada subsistema um conjunto de ações foram delineadas como sugestões de implantação do TBL a fim de alcançar a Gestão Sustentável de Pessoas. O Quadro 26 a seguir apresenta as ações.

Quadro 26. Ações da Gestão Sustentável de Pessoas por Subsistema

\begin{tabular}{|c|c|}
\hline SUBSISTEMA & AÇÕES \\
\hline \multirow{3}{*}{$\mathbf{R} \& \mathbf{S}$} & $\begin{array}{l}\text { - Descrições de cargos e de vagas com itens englobando gestão ambiental, social, e } \\
\text { econômica. }\end{array}$ \\
\hline & • Comunicação da marca e ações de sustentabilidade organizacional pela empresa. \\
\hline & $\begin{array}{l}\text {-Utilização de questões sociais, ambientais e econômicas durante o processo seletivo } \\
\text { (dinâmicas, testes, provas nos concursos para os bancos públicos, etc.). }\end{array}$ \\
\hline
\end{tabular}




\begin{tabular}{|c|c|}
\hline SUBSISTEMA & AÇÕES \\
\hline \multirow{4}{*}{ T\&D } & -Treinamento dos trabalhadores em questões sociais, ambientais e econômicas. \\
\hline & $\begin{array}{l}\text { •Envolvimento com parceiros (sindicais e outras instituições) para treinamentos que } \\
\text { incluem o TBL. }\end{array}$ \\
\hline & $\begin{array}{l}\text {-Estruturar treinamento para a motivação e envolvimento dos trabalhadores, objetivando } \\
\text { aumentar suas participações e melhorias em ações que envolvam o TBL. }\end{array}$ \\
\hline & - Treinar as lideranças para as questões do TBL. \\
\hline \multirow{7}{*}{$\begin{array}{l}\text { GDA } \\
\text { SPR }\end{array}$} & $\begin{array}{l}\text {-Desenvolver práticas para estimular o envolvimento dos trabalhadores com os pilares do } \\
\text { TBL, como newsletter, grupos para solução de problemas, sugestões, etc. }\end{array}$ \\
\hline & $\begin{array}{l}\text { - Sistema de Gestão de Desempenho e Avaliação que inclua indicadores sociais, ambientais } \\
\text { e econômicos de desempenho. }\end{array}$ \\
\hline & $\begin{array}{l}\text {-Definição de metas e responsabilidade para com os } 3 \text { âmbitos do TBL aplicáveis em todos } \\
\text { os níveis da organização e suas respectivas avaliações. }\end{array}$ \\
\hline & -Recompensas para sugestões dos trabalhadores no sistema de gestão pautado no TBL. \\
\hline & $\begin{array}{l}\text {-Estruturar esquema de metas e recompensas interligando as habilidades e ganhos na } \\
\text { gestão do TBL, inclusive nos programas de remuneração variada. }\end{array}$ \\
\hline & $\begin{array}{l}\text { •Estruturar parte da remuneração dos gestores baseada na boa gestão dos três pilares do } \\
\text { TBL. }\end{array}$ \\
\hline & $\begin{array}{l}\text { - Organizar premiações baseadas na gestão do TBL, como certificados e reconhecimentos } \\
\text { públicos. }\end{array}$ \\
\hline \multirow{9}{*}{ SSQVT } & •Proporciona jornada de trabalho razoável, de modo que as horas extras sejam raras. \\
\hline & $\begin{array}{l}\text {-Promove iniciativas de conscientização de saúde, segurança no trabalho e qualidade de } \\
\text { vida. }\end{array}$ \\
\hline & $\begin{array}{l}\text { - Mensura as causas de acidentes no trabalho de modo a delinear mudanças para que elas } \\
\text { não ocorram mais. }\end{array}$ \\
\hline & - Tratar os colaboradores seguindo os princípios de respeito, transparência, honestidade. \\
\hline & -Promove iniciativas de combate ao assédio moral. \\
\hline & - Respeita as leis trabalhistas e não possui qualquer tipo de trabalho infantil ou forçado. \\
\hline & $\begin{array}{l}\text { - Garante a liberdade sindical e a negociação coletiva, melhorando a qualidade dos acordos } \\
\text { e a solução de conflitos. }\end{array}$ \\
\hline & -Combate à todos os tipos de preconceito, garantindo bons relacionamentos na empresa. \\
\hline & $\begin{array}{l}\text {-Promove o desenvolvimento das capacidades dos colaboradores, ao mesmo tempo que } \\
\text { oferece oportunidades de crescimento e segurança. }\end{array}$ \\
\hline
\end{tabular}

Fonte: Elaborado pela autora. 


\section{Etapa 5: Comparação da Etapa 4 com a Etapa 2}

Essa etapa visa comparar o modelo conceitual da etapa anterior com a figura da etapa 2. No caso da análise aqui realizada, o modelo foi desenvolvido para otimizar os benefícios que a SSM poderá trazer na gestão de pessoas do setor bancário brasileiro.

A fim de equilibrar os investimentos do setor nos 3 aspectos (social, ambiental e econômico), a Gestão Sustentável de Pessoas visa contemplar ações capazes de construir as capacidades da força de trabalho, proporcionando a tomada de decisão participativa, a gestão da diversidade, os níveis elevados de saúde no local de trabalho e indicadores de segurança e desempenho que refletem preocupações éticas e os princípios da sustentabilidade (KRAMAR, 2014).

Para essas ações se consolidarem é importante que a área de Gestão de Pessoas esteja alinhada com o alto escalão das empresas, e que haja intenção por parte deles de integrarem essas diretrizes aos seus negócios.

A transformação seria a chave da implementação dessas ações, onde o equilíbrio entre os 3 âmbitos do TBL ocorresse, a ponto do setor bancário ser capaz de promover as mudanças e servir de referência para outros setores.

A Figura 9 a seguir demonstra o modelo conceitual da Gestão Sustentável de Pessoas no Setor Bancário Brasileiro.

Figura 9. Gestão Sustentável de Pessoas no Setor Bancário Brasileiro

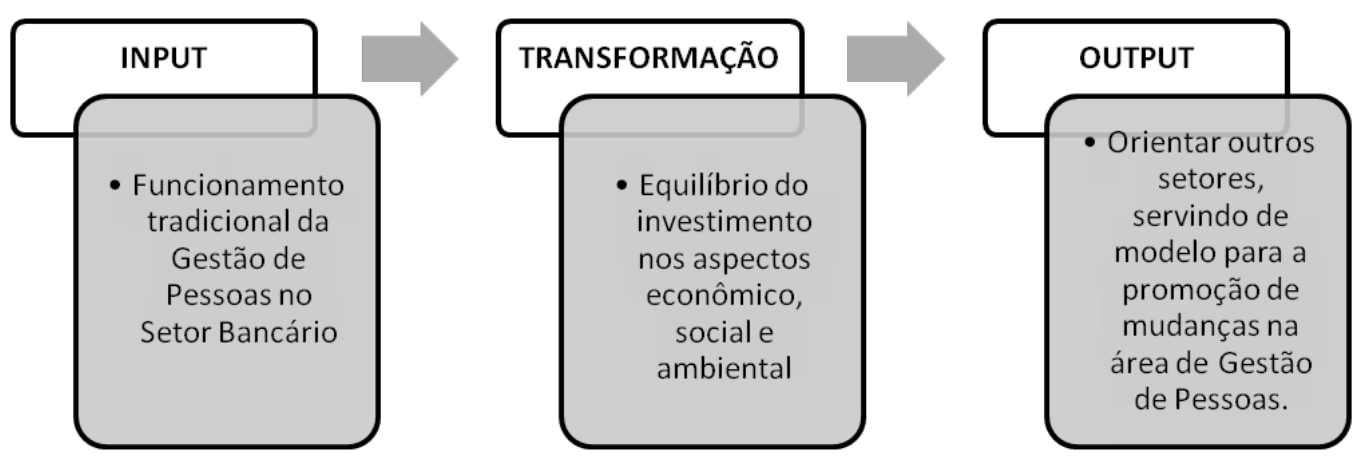

Fonte: Elaborado pela autora.

A Figura 10 representa a transformação advinda da GSP. O input (entrada) está no funcionamento tradicional da GP do setor bancário brasileiro, e o objetivo é equilibrar esse setor nos investimentos dos três aspectos do TBL. Logo, o output (saída) está na orientação 
do caminho a ser seguido por outros setores, servindo de modelo na promoção das mudanças na área.

Diante das análises já realizadas no decorrer deste trabalho, algumas restrições acontecem nas ações sugeridas. Os processos de recrutamento e seleção, os programas de pagamento e recompensas, bem como os métodos de avaliação de desempenho, são ações que exigem uma metodologia empírica, além dos métodos utilizados, para que as práticas utilizadas pelo setor bancário possam ser identificadas com mais profundidade.

As áreas de treinamento e desenvolvimento, assim como a de saúde, segurança e qualidade de vida no trabalho tem demonstrado as iniciativas para envolver os colaboradores na conscientização das diretrizes da sustentabilidade. Porém, não é linear em todos os bancos analisados, sendo uns com mais iniciativas que os outros. Logo, as mudanças desejadas são descritas na próxima etapa.

\section{Etapa 6: Mudanças possíveis desejadas}

Nesta etapa verifica-se a viabilidade da implantação das mudanças desejadas. Na última década as discussões em torno de um modelo de gestão sustentável de pessoas surgiram. Embora a literatura tenha se desenvolvido, no intuito de lidar com a relação entre as práticas de gestão de pessoas e os resultados além dos predominantemente financeiros (KRAMAR, 2014), não existem estudos aplicados nas organizações.

Como o setor bancário apresenta indícios de conscientização e aplicação da sustentabilidade em suas ações e iniciativas, integrar e embutir cada um dos aspectos (ambiental, econômico e social) de maneira equilibrada, contemplando principalmente seu público interno, será viável. Em suma, não são identificadas barreiras estruturais para as mudanças de nenhum dos subsistemas.

A fim de alinhar a Gestão Sustentável de Pessoas à todos os níveis organizacionais, o processamento demanda o tempo das mudanças. Essa transformação visa contribuir para a qualidade, manutenção e continuação da vida de todos os seres vivos e instituições, pois cada pessoa e cada organização é responsável universal por tudo que os cercam.

Assim, o Modelo Conceitual de Gestão Sustentável de Pessoas no Setor Bancário Brasileiro foi descrito na Figura 10, no intuito de delinear um guia de implicações práticas que fossem claras e objetivas para serem seguidas pelo setor bancário. 
Figura 10. Modelo Conceitual de Gestão Sustentável de Pessoas no Setor Bancário Brasileiro

\section{Gestão Sustentável de Pessoas no Setor Bancário Brasileiro}

\section{R\&S \\ Descrições de cargos e de vagas com itens englobando gestão ambiental, social, e econômica;}

Comunicação da marca e ações de sustentabilidade organizacional pela empresa;

Utilização de questões sociais, ambientais e econômicas durante 0 processo seletivo (dinâmicas, testes, provas nos concursos para os bancos públicos, etc.).

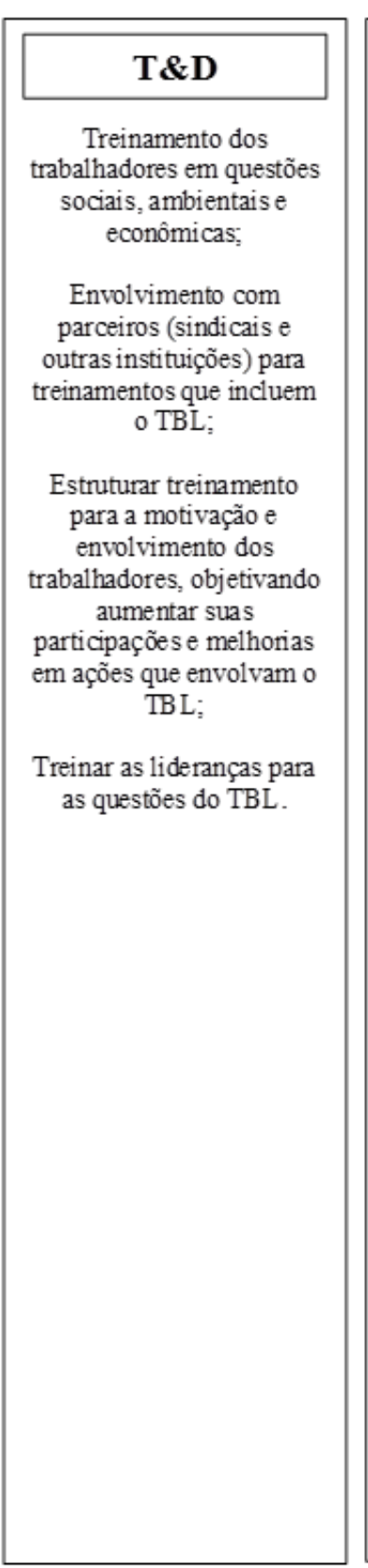

\section{GDA, SPR}

Desenvolver práticas para estimular o envolvimento dos trabalhadores com os pilares do TBL, como newsletter, grupos para solução de problemas, sugestões, etc.;

Sistema de Gestão de Desempenho e Avaliação que inclua indicadores sociais, ambientais e econômicos de desempenho;

Definição de metas e responsabilidade para com os 3 âmbitos do TBL aplicáveis em todos os niveis da organização e suas respectivas avaliações;

Recompensas para sugestões dos trabalhadores no sistema de gestão pautado no TBL;

\section{Estruturar esquema de} metas e recompensas interligando as habilidades e ganhos na gestão do TBL, inclusive nos programas de remuneração variada;

Estruturar parte da remuneração dos gestores baseada na boa gestão dos três pilares do TBL;

Organizar premiações baseadas na ge stão do TBL, como certificados e reconhecimentos públicos.

\section{SSQVT}

Proporciona jomada de trabalho razoável, de modo que as horas extras sejam raras;

Promove iniciativas de conscientização de saúde, segurança no trabalho $\mathrm{e}$ qualidade de vida;

Mensura as causas de acidentes no trabalho de modo a delinear mudanças para que elas não ocorram mais;

Tratar os colaboradores seguindo os principios de respeito, transparência, honestidade;

Promove iniciativas de combate ao assédio moral;

Respeita as leis trabalhistas e não possui qualquer tipo de trabalho

infantil ou forçado;

Garante a liberdade sindical e a negociação coletiva, melhorando a qualidade dos acordos e a solução de conflitos;

Combate à todos os tipos de preconceito, garantindo bons relacionamentos na empresa; Promove o desenvolvimento das capacidades dos colaboradores, ao mesmo tempo que oferece oportunidades de crescimento e segurança.

Fonte: Elaborado pela autora. 


\section{Etapa 7: Ações para melhorar a situação problemática}

Para a efetividade da implementação dessas ações, primeiramente a área de Gestão de Pessoas deve propor aos níveis hierárquicos mais altos da instituição a intenção de alinhar suas ações à sustentabilidade organizacional.

Com esse aval, cada subárea da Gestão de Pessoas deverá desenhar estratégias de mudanças a serem implementadas e um planejamento adequado. Com base no modelo da Etapa 4, o planejamento e desenho das ações poderiam contar com a participação do Sindicato dos Bancários e da Federação Brasileira dos Bancos, para que haja coesão e satisfação tanto para os bancos, quanto aos colaboradores das instituições.

A partir dessa etapa, um teste piloto na instituição com o maior número de funcionários poderá ocorrer num primeiro momento. Logo, identifica-se se existem melhorias a serem realizadas, verificando a necessidade de reiniciar o processo da metodologia SSM.

Além disso, há a influência dos contextos institucionais, os econômicos, sociais, tecnológicos e regulatórios que são fatores determinantes no desenvolvimento das estratégias e as políticas de gestão de pessoas.

\section{CONSIDERAÇÕES FINAIS}

Neste capítulo são apresentadas as conclusões deste trabalho, analisando os resultados encontrados e a validade das proposições. São descritas as implicações teóricas e práticas, as limitações da pesquisa e sugestões para os próximos estudos.

\subsection{CONCLUSÕES DA PESQUISA}

Para delinear as considerações finais desta pesquisa, o problema investigado deve ser retomado: “a gestão de pessoas do setor bancário brasileiro está alinhada às estratégias de sustentabilidade organizacional?".

Deste modo, o objetivo principal foi analisar as iniciativas da gestão sustentável de pessoas no setor bancário brasileiro. Delimitou-se então os objetivos específicos, que visaram (i) identificar as práticas de gestão de pessoas reportadas nos relatórios anuais ou de sustentabilidade; (ii) levantar as ações trabalhistas movidas pelos trabalhadores do setor bancário finalizadas no ano de 2014; (iii) identificar a visão do Sindicato dos Bancários e Financiários de São Paulo, Osasco e Região e da Federação Brasileira de Bancos quanto às práticas de gestão de pessoas praticadas pelos bancos; e (iv) propor um framework da gestão 
sustentável de pessoas. Todos os objetivos foram cumpridos, e as proposições foram verificadas por meio das metodologias utilizadas. O Quadro 27 a seguir, apresenta a descrição dos objetivos específicos, as respectivas proposições e os resultados das suas verificações.

\section{Quadro 27. Resultado da verificação das proposições da pesquisa}

\begin{tabular}{|c|c|c|}
\hline Objetivos Específicos & Proposição & Verificação Final \\
\hline $\begin{array}{l}\text { Conhecer as práticas de gestão } \\
\text { de pessoas reportadas pelos } \\
\text { bancos. }\end{array}$ & $\begin{array}{l}\text { 1. Os relatórios reportados pelas organizações } \\
\text { do setor bancário brasileiro contemplam os } \\
\text { tópicos dos subsistemas de gestão de pessoas. }\end{array}$ & Confirmada parcialmente \\
\hline $\begin{array}{l}\text { Levantar os acórdãos } \\
\text { trabalhistas movidos pelos } \\
\text { trabalhadores do setor } \\
\text { bancário finalizadas no ano de } \\
2014 \text {. }\end{array}$ & $\begin{array}{l}\text { 2. O não equilíbrio entre a vida profissional e a } \\
\text { vida pessoal podem resultar em queixas } \\
\text { trabalhistas. }\end{array}$ & Confirmada \\
\hline $\begin{array}{l}\text { Identificar a visão do } \\
\text { Sindicato dos Bancários e } \\
\text { Financiários de São Paulo, } \\
\text { Osasco e Região e da } \\
\text { Federação Brasileira de } \\
\text { Bancos quanto às práticas de } \\
\text { gestão de pessoas praticadas } \\
\text { pelos bancos. }\end{array}$ & $\begin{array}{l}\text { 3. O setor bancário brasileiro tem integrado a } \\
\text { sustentabilidade em suas ações de gestão de } \\
\text { pessoas. }\end{array}$ & Confirmada \\
\hline
\end{tabular}

Fonte: Elaborado pela autora.

A primeira proposição $(\mathrm{P} 1)$ se relaciona com o objetivo principal deste trabalho de analisar as iniciativas da gestão sustentável de pessoas no setor bancário brasileiro. Dentro dos subsistemas de Gestão de Pessoas analisados, foram elencados: Recrutamento e Seleção (R\&S), Treinamento e Desenvolvimento (T\&D), Sistema de Pagamento e Recompensa (SPR), Gestão de Desenvolvimento e Avaliação (GDA), e Saúde, Segurança e Qualidade de Vida no Trabalho (SSQVT).

No R\&S as práticas não são relatadas com detalhes de como é o processo para atrair e reter talentos nas organizações. Algumas informações tiveram que ser obtidas nas páginas eletrônicas dos bancos analisados, e ainda assim, eram descritas de maneira bem geral. O foco maior dos relatos estava em índices de diversidade, contemplando as questões de número de mulheres nos quadros de colaboradores, de pessoas com necessidades especiais, e de afrodescendentes.

A área de T\&D apresentou, de modo geral, grandes investimentos em contemplar as iniciativas da sustentabilidade organizacional em suas ações. A maior preocupação refere-se à questão da liberação do crédito, principalmente, já que o risco envolve o banco também. Essa área é a que proporciona orientação quanto ao comportamento dos colaboradores para que 
realizem suas atividades de acordo com os objetivos das organizações (JACKSON et al., 2011; JABBOUR et al., 2008).

Das práticas reportadas nesta área, foram encontrados treinamentos para as lideranças, colaboradores e stakeholders, disponibilização de cursos online, financiamentos de outras formas de educação tanto para o público interno, quanto para o externo. Tais iniciativas aprimoram o conhecimento, envolvendo a sustentabilidade e criando subsídios para que suas diretrizes se enraízem nos colaboradores.

Os subsistemas de SPR e GDA foram analisados concomitantemente, pois são áreas que se inter-relacionam mais que as outras analisadas. As políticas, metas e incentivos dos bancos, foram de modo geral, detalhadas mais pelo banco Itaú Unibanco.

Schaltegger e Wagner (2006) afirmam que a gestão do desempenho visando a sustentabilidade requer um quadro de gestão capaz de unir as áreas ambientais e sociais com a estratégia comercial e competitiva da organização, e por outro lado integrar as informações ambientais e sociais com as informações de negócios no âmbito econômico e com os relatórios de sustentabilidade. Esses subsistemas tem grande papel no incentivo aos colaboradores para que desenvolvam habilidades, atitudes e conhecimentos que alcancem as metas organizacionais, proporcionando melhorias na organização (RENWICK et al., 2013).

Assim, como a área de R\&S, essas áreas demandam estudos empíricos nos bancos, principalmente pautando o foco na inclusão do TBL nas ações organizacionais, sugeridos pelos autores Renwick et al. (2013), Greenwood (2012), Kramar (2014) e Ehnert (2009), de modo que a análise fique mais completa, já que nos relatórios analisados as informações encontradas foram restritas.

Já a área de SSQVT, apresentou de modo geral algumas iniciativas que contemplam a prevenção de acidentes de trabalho, os meios que os colaboradores tem de realizarem denúncias, além dos índices e taxas relativos à absenteísmo, dias perdidos de trabalho, de doenças ocupacionais, lesões.

Porém, o reporte não foi linear em todos os bancos. O Santander, por exemplo, não apresentou nenhuma informação referente à essa área, apesar de relatar o número de queixas recebidas. O número de óbitos nas organizações é relatado apenas pelo Banco do Brasil e Itaú Unibanco, e os tipos de queixas trabalhistas apenas pelo Itaú Unibanco e Bradesco.

Assim, a primeira proposição (P1) levantada foi confirmada parcialmente, pois não houve uma regularidade e linearidade nos reportes analisados. $\mathrm{O}$ subsistema de T\&D foi o que mais atendeu ao sugerido para verificação das ações, e as informações relativas aos outros subsistemas precisariam de outras metodologias para serem identificadas. 
O segundo objetivo específico delineado foi o levantamento dos acórdãos finalizados em 2014 movidos pelos trabalhadores do setor bancário, a fim de atender a segunda proposição (P2) de que o não equilíbrio entre a vida profissional e a vida pessoal podem resultar em queixas trabalhistas.

Mesmo com os processos de reestruturação devido aos avanços tecnológicos e as modificações organizacionais consequentes, como a intensificação do ritmo laboral, as novas exigências e qualificações que o setor bancário passou a demandar (SILVA e NAVARRO, 2012; SEGNINI, 1999), os maiores índices de queixas trabalhistas encontrados em todos os bancos são relativos às horas extras e seus reflexos.

Esse resultado se esbarrou na legislação da jornada de trabalho dos bancários, de 30 horas semanais. Apesar da questão das metas abusivas impostas aos trabalhadores, trazidas pelo Sindicato dos Bancários e que poderiam refletir nas horas extras, também foi informado pela Febraban que nos contratos de trabalho, os funcionários assinam que trabalharão 40 horas semanais, como em outras organizações. Esse tópico apresenta muitas divergências, muitas discussões, e poucos acordos para que se modifique a jornada de trabalho dos bancários.

Outro item analisado nos acórdãos refere-se a jornada de trabalho, e os índices apresentados giraram em torno de 2 a $6 \%$, diferente dos relativos às horas extras que ficaram em torno de 30 a 40\%. Por fim, a segunda proposição (P2) foi confirmada, já que ao não respeitar a legislação trabalhista do setor, as horas extras culminam em queixas trabalhistas, implicando no não equilíbrio entre a vida pessoal e profissional dos bancários. Apesar da brecha na legislação facilitar a ocorrência de pedidos nessa área, o setor não tem respeitado a conquista dos trabalhadores da jornada de trabalho de 30 horas semanais.

A terceira proposição $(\mathrm{P} 3)$ refere-se a demonstração de que o setor bancário brasileiro integra em suas ações de gestão de pessoas a sustentabilidade. Mesmo que ainda precise de melhorias nas ações organizacionais, o setor tem apresentado a intenção de envolver o tripé em suas iniciativas.

O motivo principal pode ser parte dos protocolos de exigências do Estado, Prefeitura, Órgãos do Governo Federal, ONGs, Ministério Público Federal, além de outros órgãos que também exigem a comprovação do envolvimento da sustentabilidade nas ações dos bancos. Essa crescente consciência pública sobre a importância das organizações na contribuição para o desenvolvimento sustentável (EHNERT et al., 2015), confirma a proposição 3.

Além disso, a crescente concorrência mundial requer um desenvolvimento do potencial interno das organizações, já que são as pessoas que mantêm o sistema 
administrativo em operação. Dessa forma desenvolver um sistema de gestão de pessoas capaz de sensibilizar a todos, pode ser visto como vital no alcance da vantagem competitiva (SAVANEVICIEN e STANKEVICIUTE, 2012).

Logo, o desafio de unir a Gestão de Pessoas aos aspectos da Sustentabilidade Organizacional culminou na intenção de propor um quadro de ações da Gestão Sustentável de Pessoas, de modo a integrar as práticas de todos os subsistemas às diretrizes da Sustentabilidade Organizacional.

As práticas de gestão de pessoas devem ter flexibilidade para construir capacidades de forças de trabalho, que respeitem a gestão da diversidade, os níveis de saúde e segurança no local de trabalho, que vão refletir em preocupações éticas. Além disso, o desempenho da organização deve ser medido com indicadores que agreguem o bem-estar do colaborador, da comunidade ao entorno e da qualidade de vida (KRAMAR, 2014).

Assim, a metodologia sistêmica Softy System Methology, proposta por Checkland (1981) foi desenvolvida. Embora estudos de Gestão Sustentável de Pessoas tenham crescido, as pesquisas tem sido mais conceituais e menos aplicadas. Assim, desenvolver um guia de implicações práticas que sejam claras e objetivas de serem seguidas era uma necessidade e uma lacuna a ser explorada (EHNERT et al., 2015).

Como a Gestão de Pessoas representa um importante papel para alinhar a sustentabilidade organizacional às ações internas das instituições. A maior contribuição desta pesquisa foi o modelo conceitual com um quadro de sugestões de ações por subsistemas da área. Por meio deste, o apoio, tanto estratégico quanto operacional, integrando a área à sustentabilidade organizacional poderá produzir resultados sinérgicos no setor bancário brasileiro (JAMALI et al., 2015).

Por fim, com o avanço proporcionado nas ações da Gestão Sustentável de Pessoas, outros setores e outros pesquisadores podem estruturar, desenvolver e investir nessas iniciativas, privilegiando igualmente os aspectos sociais, econômicos e ambientais nas organizações.

\subsection{LIMITAÇÕES DA PESQUISA}

As limitações desta pesquisa decorrem tanto da literatura quanto do método utilizado na pesquisa. A influência nos resultados obtidos e já destacados podem ser considerados como sugestões para futuros estudos, a fim de proporcionar melhorias e aperfeiçoamento à esta pesquisa. 
Dentre as limitações provenientes da literatura estão as diferentes definições de sustentabilidade organizacional e responsabilidade social corporativa, sendo consideradas por alguns autores como semelhantes, e por outros como divergentes. Tais consistências culminam em dificuldades de comparação com outros resultados de outras pesquisas.

Outra dificuldade encontrada foi na definição dos subsistemas de Gestão de Pessoas. A literatura que traz essas classificações é antiga e divergente. O estudo de Renwick et al. (2013) foi o único encontrado com os diferentes subsistemas, mas com ações pautadas apenas no aspecto ambiental. Apesar de informar a importância dessas ações no bem-estar dos colaboradores, não apresentava a classificação do subsistema de Saúde, Segurança e Qualidade de Vida no Trabalho. Desse modo, todos os subsistemas foram adaptados para esta pesquisa.

Além disso, a literatura de Gestão Sustentável de Pessoas ainda é recente e com definições muito amplas, dificultando o delineamento das ações sugeridas para cada subsistema e na análise das práticas reportadas pelo setor bancário brasileiro.

Sob o ponto de vista metodológico, algumas maiores dificuldades foram encontradas. A primeira foi o uso de dados secundários para as análises, que podem culminar na não representação da realidade. Tal dificuldade restringiu a análise dos subsistemas de R\&S, SPR e GDA, por não ser possível identificar as ações com detalhamento. Assim, os resultados podem ter sido comprometidos por essa limitação.

A segunda dificuldade foi na etapa das entrevistas, com o Sindicato dos Bancários e a Febraban. Primeiro que houve o cancelamento da entrevista com a Presidenta do Sindicato dos Bancários poucas horas antes da realização da mesma, e nenhuma flexibilidade em realiza-la em outro dia ou por outros meios que não fosse o presencial. Com insistência, foi conseguido que outro responsável se disponibilizasse em realiza-la, porém, com a restrição do tempo proporcionado, que refletiram na não riqueza das respostas, o que pode ter influenciado nos resultados obtidos.

A segunda dificuldade se pautou na não especificidade das entrevistas nos bancos analisados nesta pesquisa. Os respondentes se dispuseram a falar do setor bancário em geral, e não dos bancos componentes da amostra deste trabalho. Diante do exposto, algumas sugestões de próximos estudos estão descritas no item a seguir.

\subsection{SUGESTÕES PARA OS ESTUDOS FUTUROS}

Com a ponderação dos resultados e das limitações encontradas nesta pesquisa, 
algumas sugestões de estudos futuros foram delineados.

No que se refere às limitações encontradas na literatura, primeiro sugere-se que haja consenso entre os autores na definição de sustentabilidade organizacional e responsabilidade social corporativa, a fim de facilitar a comparação de estudos e a aplicação das teorias em diferentes setores, países, entre outros possíveis estudos.

Ainda no âmbito teórico, sugere-se que as classificações dos subsistemas de Gestão de Pessoas sejam atualizados, com uma discussão teórica mais aprofundada. E ainda, que os estudos de Gestão Sustentável de Pessoas (GSP) apresentem mais pesquisas empíricas que teóricas.

Para auxiliar a aplicação desta teoria, estudos mensurando a evolução da internalização dos conhecimentos da sustentabilidade organizacional nos funcionários, levantando quais competências ainda precisam de mais investimentos, e qual aspecto tem sido o mais contemplado (econômica, social, ambiental), auxiliaria o mapeando e definição das ações que devem ser tomadas visando o equilíbrio do tripé.

Sob o ponto de vista metodológico, é primordial que uma pesquisa empírica, analisando os bancos de maneira primária, seja realizada. Além de ser possível conhecer mais profundamente as práticas do setor, a aplicação do modelo conceitual trazido pela metodologia sistêmica de Gestão Sustentável de Pessoas pode contribuir na mensuração e aprimoramento das ações sugeridas. Assim, o modelo pode ser replicado em outros setores, outros países, investigando as tendências, e delineando níveis de adesão das organizações. 


\section{REFERÊNCIAS}

ABREU, M. C. S. How to define an environmental policy to improve corporate sustainability in developing countries. Business Strategy and the Environment, v. 18, n. 8, p. 542 - 556, 2009.

ALVES, A. P. S.; ALMEIDA, A. M. F. O valor do diploma nas práticas de recrutamento de grandes empresas. Cadernos de Pesquisa, v. 39, n. 138, p. 939-962, 2009.

ANDRADE, M. A. M.; GOSLING, M.; LIMA, G. C. O. A "Responsabilidade Social” dos Bancos no Brasil. Revista de Gestão Social e Ambiental, v. 5, n. 3, p. 168-182, 2011.

APPEL, H.; BITENCOURT, C. C. Gestão de Pessoas por Competência: Institucionalização, Possibilidades e Dificuldades implícitas nas relações trabalhistas brasileiras. Organizações e Sociedade, v. 15, n. 46, p. 176-193, 2008.

ASSAF NETO, A. Mercado Financeiro. 12. ed. São Paulo: Editora Atlas, 2014. 380 p.

BACEN (Banco Central do Brasil). 50 maiores bancos e o consolidado do Sistema Financeiro Nacional. Disponível em < http://www4.bcb.gov.br/top50/port/top50.asp >. Acesso em: $10 \mathrm{de}$ jun. de 2015.

BANCO DO BRASIL. História do Banco do Brasil. Disponível em:

$<$ http://www.bb.com.br/portalbb/page3,136,3527,0,0,1,8.bb?codigoMenu=204\&codigoNotici $\mathrm{a}=691>$. Acesso em: 19 ago. 2014.

Bancos e Serviços financeiros [internet]. Você S/A; 2013. Disponível em:

$<$ http://exame.abril.com.br/revista-voce-sa/melhores-empresas-para-trabalhar/2013/bancos-eservicos-financeiros/>. Acesso em: 25 maio 2014.

BARDIN, L. Análise de Conteúdo. Lisboa: Edições 70, 2009.

BAUMGARTNER, R. J.; DANIELA, E. Corporate Sustainability Strategies: Sustainability Profiles and Maturity Levels. Sustainable Development, v. 1, n. 8, p. 76-89, 2010.

BEBBINGTON, J.; LARRINAGA, C.; MONEVA, J. M. Corporate social reporting and reputation risk management. Accounting, Auditing \& Accountability Journal, v. 21 n. 3, p. 337-361, 2008.

BOHLANDER, G.; SNELL, S.; SHERMAN, A. Administração de Recursos Humanos. 1 ed. São Paulo: Pioneira Thomson Learning, 2005. 547 p.

BORGES, L. O.; MOURÃO, L. O trabalho e as organizações: atuações a partir da psicologia. Porto Alegre: Artmed, 2013. 699 p.

BRADESCO. Nossa história. Disponível em:

$<$ http://www.bradesco.com.br/html/classic/sobre/nossa-historia.shtm> Acesso em: 19 de Agosto de 2014.

BRANDÃO, H. P.; ZIMMER, M. V.; PEREIRA, C. G.; MARQUES, F.; COSTA, H. V.; CARBONE, P. P.; ALMADA, V. F. Gestão de desempenho por competências: integrando a gestão por competências, o balanced scorecard e a avaliação 360 graus. Revista de Administração Pública, v. 42, n. 2, p. 875-898, 2008.

BRASIL. Ministério do Meio Ambiente. 2009. MMA quer saber se bancos estão cumprindo Protocolo Verde. Disponível em:

$<$ http://www.mma.gov.br/informma/item/5445-mma-quer-saber-se-bancos-estao-cumprindoprotocolo-verde> Acesso em: 22 ago. 2014. 
BROWN, H. S.; JONG, M.; LEVY, D. L. Building institutions based on information disclosure: lessons from GRI's sustainability reporting. Journal of Cleaner Production, v. 17, n. 6, p. 571-580, 2009.

BROWN, H. S.; MARTIN, J.; LESSIDRENSKA, T. The rise of the Global Reporting Initiative: a case of institutional entrepreneurship. Environmental Politics, v. 18, n. 2, p. 182$200,2009$.

CAIXA ECONÔMICA FEDERAL. História. Disponível em:

$<$ http://www14.caixa.gov.br/portal/acaixa/home/a_vida_pede_mais_que_um_banco/historia $>$. Acesso em: 20 ago. 2014.

CÁMARAS. Responsabilidad Social Corporativa en la Pyme. 2006. Disponível em: $<$ http://www.iegd.org/spanish800/adjuntos/responpyme.pdf > Acesso em: 07 ago. 2014.

CAMPOS, L. M. S.; SEHNEM, S.; OLIVEIRA, M. A. S.; ROSSETTO, A. M.; COELHO, A. L. A. L.; DALFOVO, M. S. Relatório de sustentabilidade: perfil das organizações brasileiras e estrangeiras segundo o padrão da Global Reporting Initiative. Gestão \& Produção, v. 20, n. 4, p. 913-926, 2013.

CARNEIRO, N. S. Contra a "violência de inexistir": psicologia crítica e diversidade humana. Psicologia e Sociedade, v. 25, n. 1, p. 40-47, 2013.

CARVALHO, I. M. V.; PASSOS, A. E. V. M.; SARAIVA, S. B. C. Recrutamento e Seleção por competências. Rio de Janeiro: Ed. FGV, 2008, 128 p.

CEBDS. Câmaras Temáticas - Finanças. Disponível em:

$<$ http://cebds.org.br/camaras_tematicas/financas/> Acesso em: 22 ago. 2014.

CEZARINO, L. O; LIBONI, L.; MARTINELLI, D. P. Metodologia SSM e sua aplicação na intervenção organizacional em uma empresa de propaganda. In: Anais do I CBS. Ribeirão Preto: FEARP/USP, 2006.

CEZARINO, L. O. Mensuração da interdisciplinaridade nos cursos de graduação em Administração. Tese (Doutorado) - Universidade de São Paulo, São Paulo, 2013. 279 p.

CHECKLAND, P. Systems thinking, systems practice. Hoboken: John Wiley \& Sons, 1981.

CHENG, C. Y.; FET, A.M.; HOLMEN, E.. Using a Hexagonal Balanced Scorecard approach to integrate Corporate Sustainability into Strategy, Proceedings for the 16th International

Sustainable Development Research Conference 2010, Track: Implementing Integrated Corporate Sustainability Frameworks; Hong Kong: June, 2010.

CLARO, P. B. O.; CLARO, D. P.; AMÂNCIO, R. Entendendo o conceito de sustentabilidade nas organizações. Revista de Administração da Universidade de São Paulo, v.43, n. 4, p. 289-300, 2008.

COHEN, E.; TAYLOR, S.; CAMEN, M. M. HRM's Role in Corporate Social and

Environmental Sustainability. (2012) Disponível em:

$<$ http://www.shrm.org/about/foundation/products/documents/4-

12\%20csr\%20report\%20final\%20for\%20web.pdf $>$. Acesso em: 01 abril 2015.

COOPER, D. R.; SCHINDLER, P. S. Métodos de pesquisa em administração. 10 ed. Porto Alegre: Bookman, 2011.

CORAZZA, G. Crise e reestruturação bancária no Brasil. Análise (PUCRS), v. 12, p. 21-42, 2001.

CORTINA, A. Ética y formación universitaria. Revista Iberoamericana De Educación, n. 29, p. 45-64, 2002. 
CYSNE, R. P.; COSTA, S. G. S. Reflexos do Plano Real sobre o sistema bancário brasileiro. Revista Brasileira de Econia, v. 51, p. 325-346, 1996.

DAUB, C. H. Assessing the quality of sustainability reporting: an alternative methodological approach. Journal of Cleaner Production, v. 15, n. 1, p. 75-85, 2007.

DUBOIS, C. L. Z.; DUBOIS, D. A. Strategic HRM as social design for environmental sustainability in organization. Human Resource Management, v. 51, n. 6, p. 799-826, 2012.

DUTRA, J. S. Competências: Conceitos e instrumentos para a gestão de pessoas na empresa moderna. 1 ed. São Paulo: Atlas. 2004. 208 p.

DYLLICK, T.; HOCKERTS, K. Beyond the business case for corporate sustainability. Business Strategy and the environment, v.11, p.130-141, 2002.

EHNERT, I. 'Sustainability Issues in Human in Human Resource Management: Linkages, theoretical approaches, and outlines for an emerging field'. Paper prepared for 21st EIASM SHRM Workshop, Aston, Birmingham, March 28th-29th, 2006.

EHNERT, I. Sustainable Human Resources Management: A Conceptual and Exploratory Analysis from a Paradox Perspective. Springer, 2009. 316p.

EHNERT, I.; HARRY, W. Recent Developments and Future Prospects on Sustainable Human Resource Management: Introduction to the Special Issue. Management Revue, v. 23, n. 3, p. 221-238, 2012.

EHNERT, I.; PARSA, S.; ROPER, I.; WAGNER, M.; MULLER-CAMEN, M. Reporting on sustainability and HRM: a comparative study of sustainability reporting practices by the world's largest companies. The International Journal of Human Resource Management, p. 1-21, 2015.

ELKINGTON, J. Cannibals with forks: the triple bottom line of 21 st century business. Oxford: Capstone Publishing Limited, 1999.

EQUATOR PRINCIPLES. ABOUT THE EQUATOR PRINCIPLES. Disponível em: $<$ http://www.equator-principles.com/index.php/about-ep/about-ep> Acesso em: 22 ago. 2014.

EWEJE, G. A Shift in Corporate Practice? Facilitating Sustainability Strategy in Companies. Corporate Social Responsibility and Environmental Management, 18, 125-136, 2011.

FARIA, A.; SAUERBRONN, F. F. A responsabilidade social é uma questão de estratégias? Uma abordagem crítica. Revista de Administração Pública, v. 42, n.1, p. 07-33, 2008.

FEBRABAN. $1^{\circ}$ Declaração de Collevecchio - O que fazer e não fazer em um banco sustentável. Disponível em:

$<$ http://www.febraban.org.br/7Rof7SWg6qmyvwJcFwF7I0aSDf9jyV/sitefebraban/1\%AA\%2 0Cartilha $\% 20$ Febraban $\% 20 \mathrm{Caf} \%$ E9\%20com $\% 20$ Sustentabilidade $\% 20$ -

\%20Declara\%E7\%E3o\%20de\%20Collevecchio.pdf $>$. Acesso em: 22 ago. 2014.

FEBRABAN. Federação Brasileira de Bancos. Censo da Diversidade. Disponível em < http://www.febraban.org.br/7Rof7SWg6qmyvwJcFwF7I0aSDf9jyV/sitefebraban/Censo\%20d a\%20Diversidade\%202014\%20-\%20Apresenta\%E7\%E3o\%20Final\%20-\%2003-11-14.pdf>. Acesso em: 10 de jun. de 2015.

FEBRABAN. Pronunciamentos. 2011. Disponível em:

$<$ http://www.febraban.org.br/Noticias1.asp?id_texto=1203> Acesso em: 22 ago. 2014.

FERNANDES, B. H. R.; FLEURY, M. T. L.; MILLS, J. Construindo o diálogo entre competência, recursos e desempenho organizacional. RAE - Revista de Administração de Empresas, v. 16, n.4, p. 48-65, 2006. 
FLEURY, M. T. L.; FLEURY, A. Alinhando estratégia e competências. RAE - Revista de Administração de Empresas, v. 44, n.1, p. 44-57, 2004.

FLICK, U. Introdução à pesquisa qualitativa. 3 ed. Porto Alegra: Artmed, 2008. 408 p.

GABRIUNAS, I. L. La influencia del desempeño social corporativo en la satisfación laboral de los empleados: una revisión teórica desde una perspectiva multinivel. Estudos

Gerenciales, v. 26, n. 116, p. 63-81, 2010.

GODOY, A. S. Estudo de caso qualitativo. In: GODOI, C. K.; BANDEIRA-DE-MELLO, R.; SILVA, A. Pesquisa qualitativa em estudos organizacionais: paradigmas, estratégias e métodos. 2. ed. São Paulo: Saraiva, 2010.

GOLIK, M. Las expectativas de equilibrio entre vida laboral y vida privada y las elecciones laborales de la nueva generación. Cuadernos de Administración, v. 26, n. 46, p. 107-133, 2013.

GOLOB, U.; BARTLETT, J. L. Communicating about corporate social responsibility: A comparative study of CSR reporting in Australia and Slovenia. Public Relations Review, v. 33, n. 1, p. 1-9, 2007.

GPTW -GREAT PLACE TO WORK. Busca das Melhores Empresas. Disponível em: < http://www.greatplacetowork.com.br/melhores-empresas/busca-das-melhores-empresas> Acesso em: 28 ago. 2014.

GRAVINA, M. E. R.; ROCHA, L. E. Lesões por Esforços Repetitivos em bancários: reflexões sobre o retorno ao trabalho. Cadernos de Psicologia Social do Trabalho, v. 9, n. 2, p. 41-55, 2006.

GREEN, K. W.; WU, C.; WHITTEN, D.; MEDLIN, B. The impact of strategic human resource management on firm performance and HR professionals' work attitude and work performance. International Journal of Human Resource Management, v. 17, n. 4, p. 559579, 2006.

GREENWOOD, M.R. 'Ethics and HRM: A Review and Conceptual Analysis,' Journal of Business Ethics, v.36, p.261-278, 2002.

GRI, Global Reporting Initiative. Diretrizes para relato de sustentabilidade. 2013. Disponível em: < https://www.globalreporting.org/resourcelibrary/Brazilian-Portuguese-G4Part-One.pdf>. Acesso em: 14 maio 2014.

GUIMARÃES FILHO, A. D. J.; GOMES, E. R. Impactos Internos das Várias Formas Organizacionais de Atuação em Responsabilidade Social Corporativa nos Grandes Bancos no Brasil. Revista ADMpg Gestão Estratégica, v. 3, n. 1, p. 73-81, 2010.

HILTROP, J. M. The Quest for the best: Human Resources Practices to attract and retain talent. European Management Journal, v. 17, n. 4, p. 422-430, 1999.

HU, W.; WALL, G. Environmental management, Environmental Image and competitive Tourism Attraction. Journal of Sustainable Tourism, v. 13, n. 6, p. 617-635, 2005.

INFANTE, C. E.; CANTANHEDE, I. L.; MENDONÇA, F. M.; VALLE, R. A Inovação da Sustentabilidade nos Bancos Brasileiros e Internacionais. INGEPRO - Inovação, Gestão e Produção, v. 2, n. 11, p. 38-47, 2010.

INTERNATIONAL ORGANIZATION FOR STANDARDIZATION - ISO. ISO

10015/2001: Gestão da qualidade - Diretrizes para treinamento. Rio de Janeiro, 2001. 
ITAUUNIBANCO. História. Disponível em:

$<$ http://www.itauunibanco.com.br/relatoriodesustentabilidade/pt-br/historia/> Acesso em: 27 ago. 2014.

JABBOUR, C. J. C.; SANTOS, F. C. A. The central role of human resources management in the search for sustainable organizations. The International Journal of Human Resources Management, v. 19, n. 12, p. 2133-2154, 2008.

JABBOUR, C. J. C.; SANTOS, F. C. A.; FONSECA, S. A.; NAGANO, M. S. Green teams: understanding their roles in the environmental management of companies located in Brazil. Journal of Cleaner Production, v. 46, p. 58-66, 2013.

JABBOUR, C. J. C.; SANTOS, F. C. A.; NAGANO, M. S. Contributions of HRM throughout the stages of environmental management: methodological triangulation applied to companies in Brazil. The International Journal of Human Resources Management, v. 21, n. 7, p. 1049-1089, 2010.

JABBOUR, C. J. C.; SILVA, E. M.; PAIVA, E. L., SANTOS, F. C. A. Environmental management in Brazil: is it a completely competitive priority? Journal of Cleaner Production. v. 21, n. 1, p. 11-22, 2012.

JACK, E. P.; RATURI, A. S. Lessons learned from methodological triangulation in management research. Management Research News, v. 29, n. 6, p. 345-357, 2006.

JACKSON, S., RENWICK, D., JABBOUR, C. J. C., MULLER-CAMEN, M. 'State-of-theArt and Future Directions for Green Human Resource Management: Introduction to the Special Issue'. German Journal of Human Resource Management, v. 25, n. 2, p. 99-116, 2011.

JACOBI, P. R. Educação Ambiental: o desafio da construção de um pensamento crítico, complexo e reflexivo. Educação e Pesquisa, v. 31, n. 2, p. 233-250, 2005.

JAMALI, D. R.; DIRANI, A. M. E.; HARWOOD, I. A. Exploring human resource management roles in corporate social responsibility: the CSR-HRM co-creation model. Business Ethics: A European Review, v. 24, n. 2, p. 125-143, 2015.

JUNQUEIRA, L. A. P.; MAIOR, J. S.; PINHEIRO, F. P. Sustentabilidade: a produção científica brasileira entre os anos de 2000 e 2009. RGSA - Revista de Gestão Social e Ambiental, v. 5, n. 3, p. 36-52, 2011.

KRAMAR, R. Beyond strategic human resource management: is sustainable human resource management the next approach? The International Journal of Human Resource Management, v. 25, n. 8, p. 1069-1089, 2014.

KRISHNAN, M. S.; RAMASWAMY, V.; MEYER, M. C.; DAMIEN, P. Customer satisfaction for financial services: the role of products, services, and information technology. Management Science, v. 45, n. 9, p. 1194-1209, 1999.

LAKATOS, E. M.; MARCONI, M. A. Fundamentos metodologia científica. 4.ed. São Paulo: Atlas, 2001.

LARANGEIRA, S. M. G. Reestruturação produtiva no setor bancário: A realidade dos anos 90. Educação \& Sociedade, n. 61, p. 110-138, 1997.

LARSON, M.; LUTHANS, F. Potential added value of psychological capital in predicting work attitudes. Journal of Leadership and Organizational Studies, v. 13, n.2, p. 75-92, 2006. 
LEITE, M. H. R.; TOMELIN, C. A.; RAMOS, M. R. Bastidores da hotelaria: qualidade de vida no trabalho no setor de governança - camareiras dos hotéis de Foz do Iguaçu - PR Brasil. Tourism \& Management Studies, v. 10, n. Especial, p. 200-206, 2014.

LEMME, C. F. O valor gerado pela sustentabilidade corporativa. In: LINS, L.; ZYLBERSZTAJN, D. Sustentabilidade e geração de valor: a transição para o século XXI. Rio de Janeiro: Elsevier, 2010.

LIM, A.; TSUTSUI, K. Globalization and Commitment in Corporate Social Responsibility: Cross-National Analyses of Institutional and Political-Economy Effects. American Sociological Review, v. 1, n. 77, p. 69-98, 2011.

LIMONGI-FRANÇA, A. C.; ARELLANO, E. B. Os processos de recrutamento e seleção. In: As pessoas na organização. São Paulo: Ed. Gente, 2002.

MADILL, J. J.; FEENEY, L.; RIDING, A.; HAINES JR., G. H. Determinants of SME owners' satisfaction with their banking relationships: a Canadian study. International Journal of Bank Marketing, v. 20, n. 2, p. 86-98, 2002.

MALHOTRA, N. Pesquisa de marketing: uma orientação aplicada. 6.ed. Porto Alegre: Bookman, 2012.

MANKIW, N. G. Introdução à Economia. 1. ed. São Paulo: Thomson, 2005. 852 p.

MARTIN, B. R. The evolution of science policy and innovation studies. Research Policy, v. 41, n. 7, p. 1219-1239, 2012.

MARTINS, G. A.; THEÓPHILO, C. R. Metodologia da Investigação Científica para Ciências Sociais Aplicadas. 2. ed. São Paulo: Atlas, 2009. 247p.

MATIAS, A. B.; METZNER, T. D. O setor bancário brasileiro de 1990 a 2010. São Paulo: Editora Manole, 2015. 496p.

MELLO, S. C. B.; SOUZA NETO, A. F.; LEÃO, A. L. M. S.; FONSECA, F. R. B.; OLIVEIRA, P. A. S. Dimensões do relacionamento e variáveis demográficas: uma investigação com base nas opiniões dos clientes de um grande banco brasileiro. Revista de Negócios, v. 11, n. 1, p. 31-47, 2006.

MENESES, P. P. M.; ZERBINI, T. Levantamento de necessidades de treinamento: reflexões atuais. Análise, v. 20, n. 2, p. 50-64, 2010.

MILLS, J.; PLATTS, K.; BOURNE, M.; RICHARDS, H. Competing throungh competences. Cambridge: Cambridge University Press, 2002.

MOLICA, D. G.; CARVALHO NETO, A. M.; GONÇALVES, P. P. B. Responsabilidade Social Empresarial: oportunidades perdidas para trabalhadores e empregadores. Revista Brasileira de Gestão de Negócios. São Paulo, v. 10, n. 28, p. 215-233, 2008.

MONTANARI, M. G.; MIRANDA, R. A. M.; GIRALDI, J. M. E. Uma comparação quantitativa entre dois índices de competitividade. Globalização, Competitividade e Governabilidade, v. 8, n. 2, p. 121-136, 2014.

MORESI, E. Metodologia da Pesquisa. Programa de pós-graduação stricto sensu em gestão do conhecimento e da tecnologia da informação da Universidade Católica, Brasília, 2003.

MOURA, M.C.C; BITENCOURT, C.C. A articulação entre estratégia e o desenvolvimento de competências gerenciais. RAE-eletrônica, v. 5, n. 1, 2006. 
MOUTINHO, L.; SMITH, A. Modelling bank customer satisfaction through mediation of attitudes towards human and automated banking. International Journal of Bank Marketing, v. 18, n.3, p.124-34, 2000.

MUNCK, L; BORIM-SOUZA, R. Responsabilidade social empresarial e sustentabilidade organizacional: a hierarquização de caminhos estratégicos para o desenvolvimento sustentável. REBRAE - Revista Brasileira de Estratégia, v. 2, n. 2, p. 185-202, 2009.

MUNCK, L.; BORIM-SOUZA, R.; ZAGUI, C. A gestão por competências e sua relação com ações voltadas à sustentabilidade, REGE, v. 19, n. 3, p. 371-389, 2012.

NADER, M.; BERNATE, S. P. S.; SANTA-BARBARA, E. S. Predicción de la satisfacción y el bienestar en el trabajo: hacia un modelo de organización saludable en Colombia. Estudios Gerenciales, v. 30, n. 130, p. 31-39, 2014.

NOGUEIRA, E. P.; FARIA, A. C. Sustentabilidade Nos Principais Bancos Brasileiros: Uma Análise Sob A Ótica Da Global Reporting Initiative. Revista Universo Contábil, v. 8, n. 4, p. 119-139, 2012.

OIT. The Labour Principles of the United Nations Global Compact: A Guide for Business/International Labour Office, Geneva: ILO, 2008. 30 p.

PATRICK, H. A.; KUMAR, V. R. Managing workplace diversity: issues and challenges sage open. Thousand Oaks: Sage, 2012. Disponível em:

$<$ http://sgo.sagepub.com/content/2/2/2158244012444615>. Acesso em: 19 jul. 2015.

PENA, R. P. M.; COELHO, H. M. Q.; CARVALHO NETO, A. M.; TEODOSIO, A. S.; DIAS, A. S.; FERNANDES, T. Responsabilidade social empresarial e estratégia: um estudo sobre a gestão do público interno em empresas signatárias do Global Compact. In: ENCONTRO DE ESTUDOS EM ESTRATÉGIA, 2, 2005. Anais do II 3 E's. Rio de Janeiro: ANPAD, 2005.

PENROSE, E. T. The Theory of the Growth of the Firm. Oxford: Basil Blackwell, 1959.

PEREIRA, J. B. C.; HANASHIRO, D. M. M. Ser ou não ser favorável às práticas de diversidade? eis a questão. Revista de Administração Contemporânea, v. 14, n. 4, p. 670$683,2010$.

PRONI, M. W. Trabalho decente e vulnerabilidade ocupacional no Brasil. Economia e Sociedade, v. 22, n. 3, p. 825-854, 2013.

RENWICK, D. W. S.; REDMAN, T.; MAGUIRE, S. Green Human Resource Management: A Review and Research Agenda. International Journal of Management Reviews, v. 15, n. 1, p. 1-14, 2013.

RICHARDSON, J. A.; PERES, J. A. S.; CORREIA, L. M.; PERES, M. H. M.; WANDERLEY, J. C. V. Pesquisa social: métodos e técnicas. 3 ed. São Paulo: Atlas, 1989.

RODRIGUES, C. H. R.; SANTOS, F. C. A. Empowerment: ciclo de implementação, dimensões e tipologia. Gestão e Produção, v. 8, n. 3, p. 237-249, 2001.

ROSENFIELD, C. L.; PAULI, J. Para além da dicotomia entre Trabalho Decente e Trabalho Digno: Reconhecimento e Direitos Humanos. CADERNO CGESTÃO DE PESSOAS, v. 25, n. 65, p. 319-329, 2012.

SANTANDER. História. Disponível em:

$<$ http://www.santander.com.br/portal/wps/script/templates/GCMRequest.do?page=6413 $>$.

Acesso em: 21 ago. 2014. 
SAVANEVICIENE, A.; STANKEVICIUTE, Z. Human Resource Management and Performance: From Practices Towards Sustainable-Competitive Advantage. Disponível em: $<\mathrm{http}$ ://www.intechopen.com/books/globalization-education-and-managementagendas/human-resource-management-and-performance-from-practices-towards-sustainablecompetitive-advantage>. Acesso em: 5 mai. 2015.

SCHALTEGGER, S.; WAGNER, M. Integrative management of sustainability performance, measurement and reporting. International Journal of Accounting, Auditing and Performance Evaluation, v. 3, n. 1, p. 1-19, 2006.

SCHULLER; B. J.; LIDBOM, M. Competitiveness of nations in the global economy: is Europe internationally competitive? Economics \& Management, v.1, p. 934-939, 2009.

SEGNINI, L. R. P. Reestruturação nos bancos do Brasil: desemprego, subcontratação e intensificação do trabalho. Educação \& Sociedade, n. 67, p. 183-209, 1999.

SETHI, S. P.; SCHEPERS, D. H. United Nations Global Compact: the promise performance gap. Journal of Business Ethics, v. 122, n. 2, pp. 193-208, 2014.

SILVA, E. M., JABBOUR, C. J. C., SANTOS, F. C. A. Integrating environmental management and manufacturing strategy: an emerging competitive priority. International

Journal of Environmental Technology and Management, v. 10, n. 3/4, p. 397-411, 2009.

SILVA, J. L.; NAVARRO, V. L. Organização do trabalho e saúde de trabalhadores bancários. Revista Latino-Americana de Enfermagem, v. 20, n. 2, p. 226-234, 2012.

SILVA, L. S.; PINHEIRO, Tarcísio Márcio Magalhães; SAKURAI, Emília. Reestruturação produtiva, impactos na saúde e sofrimento mental: o caso de um banco estatal em Minas Gerais, Brasil. Caderno de Saúde Pública, v. 23, n. 12, p. 2949-2958, 2007.

SMITH, R. Harnessing Competencies, Capabilities and Resources. Technology Management, v. 51, n. 5, p. 47-53, 2008.

SOUZA, F. A. S.; LEMOS, A. H. C.; CAVAZOTTE, F. S. C. N.; MALVA, T. R. J. Atraindo novos funcionários para empresas de alta performance: uma crítica às razões dos profissionais de recursos humanos. Cadernos EBAPE.BR, v. 13, n. 1, p. 103-120, 2015.

SPANOS, Y. E.; PRASTACOS, G. Understanding organizational capabilities: towards a conceptual framework. Journal of Knowledge Management, v. 8, n.3, p. 31-43, 2004.

STF (Supremo Tribunal Federal). Estatísticas do STF, 2015. Disponível em:

$<$ http://www.stf.jus.br/portal/cms/verTexto.asp?servico=estatistica\&pagina=entendadecisoes $>$ . Acesso em: 28 jul. de 2015.

TEIXEIRA, A. A.; JABBOUR, C. J. C.; JABBOUR, A. B. L. S. Relationship between green management and environmental training in companies located in Brazil: A theoretical framework and case studies. International Journal Production Economics, v. 140, n.1, p. 318-329, 2012.

TOGASHI, H. F.; HACON, V. S. A evolução do debate socioambiental no Brasil: Legislação, etnoconservação e racionalidade ambiental. Economía, Sociedad y Territorio, v. 12, n. 39, p. 403-424, 2012.

TRIVIÑOS, A. N. S. Introdução à pesquisa em ciências sociais: a pesquisa qualitativa em educação. São Paulo: Atlas, 1987. 175 p.

UNEP-FI. About. Disponível em: < http://www.unepfi.org/about/> Acesso em: 22 ago. 2014. 
UNGLOBALCOMPACT - United Nations Global Compact. Os dez princípios. Disponível em: < http://www.unglobalcompact.org/Languages/portuguese/dez_principios.html>. Acesso em: 10 jul. 2014.

UNITED NATIONS. General Assembly. Disponível em:

$<$ http://www.un.org/documents/ga/res/42/ares42-187.htm>. Acesso em: 19 set. 2014.

VALENTE, M. Theorizing Firm Adoption of Sustaincentrism. Organization Studies, v. 33, n.4, p. 563-591, 2012.

VAN BELLEN, H. M. Indicadores de sustentabilidade: um levantamento dos principais sistemas de avaliação. Cadernos EBAPE.BR, v. 2, n. 1, p. 1-14, 2004.

Van MARREWIJK, Michel. Concepts and Definitions of CSR and Corporate Sustainability: Between Agency and Communion. Journal of Business Ethics, v.44, n.2-3, p.95-105, 2003.

VASCONCELOS, A. F. Qualidade de vida no trabalho: origem, evolução e perspectivas. Caderno de Pesquisa em Administração, v. 8, n. 1, p. 23-35, 2001.

VERGARA, S. C; BRANCO, P. D. Empresa humanizada: a organização necessária e possível. RAE - Revista de Administração de Empresas, v. 41, n.2, p. 20-30, 2001.

VICKERS, M.R. Business Ethics and the HR Role: Past, Present, and Future. Human Resource Planning, v. 1, n. 28, p. 26-32, 2005.

VIEIRA, V. A. As tipologias, variações e características da pesquisa de marketing. Revista FAE, v. 5, n.1, p. 61-70, 2002.

WALTON, R. Quality of working life: what is this? Slow Management Review, v. 15, n. 1, p. 11-21, 1973.

WERNERFELT, B. A Resource-based View of the Firm. Strategic Management Journal, v. 5, n. 2, p.171-180, 1984.

XIE, Y. Methodological contradictions of contemporary Sociology. Michigan Quarterly Review, v. 44, n. 3, p. 506-511, 2005. 


\section{APÊNDICE A}

\section{ROTEIRO DE ENTREVISTA}

\section{INTRODUÇÃO E ABERTURA}

1.1. Explique o objetivo da pesquisa: Sustentabilidade $>$ Triple Bottom Line $>$ Social Interno [gestão de pessoas]

1.2. Assegure o anonimato do respondente, o objetivo puramente acadêmico e que a entrevista será gravada para agilizar o processo.

1.3. Qual a sua formação e trajetória profissional?

1.4. Quais as principais atribuições da sua função?

\section{SUBSISTEMAS DE RECURSOS HUMANOS}

2.1. Como você descreveria o estágio das práticas atuais de recursos humanos no setor bancário?

2.2. Quais as principais iniciativas de mudança do setor bancário nessa área $(\mathrm{RH})$ ?

2.3. Qual a sua visão de sustentabilidade?

2.4. Quem, em sua opinião, tem cobrado mais por questões relacionadas à sustentabilidade no setor bancário? Fornecedores, clientes, funcionários?

2.5. Quais as principais questões de sustentabilidade que você conhece e estão inseridas na gestão de pessoas no setor?

2.6. Quais as principais características, pontos positivos e dificuldades em cada subsistema abaixo:

2.6.1. Recrutamento e Seleção (R\&S) (dar definição) (PRINCIPAIS CARACTERÍSTICAS, PONTOS POSITIVOS E, DIFICULDADES)

- $\quad$ Em sua opinião, como o setor tem lidado com as práticas de diversidade (não discriminação, oportunidades iguais de emprego, inclusão de pessoas) ao atrair talentos?

- Em sua opinião, quais as diferenças para atrair talentos dentre os bancos públicos e privados? O perfil das pessoas é diferente?

2.6.2. Treinamento e Desenvolvimento (dar definição) (PRINCIPAIS CARACTERÍSTICAS, PONTOS POSITIVOS E, DIFICULDADES)

- $\quad$ Em sua opinião, quais treinamentos são dados para que os colaboradores se envolvam com a sustentabilidade?

- $\quad$ Acredita que o RH tem evoluído para usar a sustentabilidade organizacional (defina isso para ele/ela) nas atividades diárias, com os cursos, palestras, workshops, disponibilizados pelo setor?

2.6.3. Gestão de Desempenho e Remuneração (dar definição) (PRINCIPAIS CARACTERÍSTICAS, PONTOS POSITIVOS E , DIFICULDADES)

- Qual sua opinião quanto a inserir metas em sustentabilidade para mensurar o desempenho dos colaboradores.

- $\quad$ Poderia me explicitar como funciona os processos de demissão do setor bancário? Existe algum limite de ações toleradas antes da demissão, as avaliações de desempenho afetam nessa decisão, como funciona? 
- Qual a importância do papel do líder para a aplicação de ações em sustentabilidade, em sua opinião?

- Qual a sua opinião sobre a estratégia de remunerar os funcionários de acordo com o seu desempenho em sugerir, aplicar, se envolver com as diretrizes da sustentabilidade?

2.6.4. Sistema de trabalho, saúde e bem estar (dar definição) (PRINCIPAIS CARACTERÍSTICAS, PONTOS POSITIVOS E, DIFICULDADES)

- Em sua opinião, qual a causa mais frequente de doenças ocupacionais no setor bancário? Por que?

- Qual a sua opinião sobre os casos de indenizações por assédio moral que os bancos recebem?

- $\quad$ Em sua opinião, quais as dificuldades para o bancário conciliar sua vida profissional com a vida pessoal?

- $\quad$ Acredita que inserir metas em sustentabilidade afetaria a saúde dos colaboradores? Aumentaria a pressão?

- A maior causa recorrente em processos trabalhistas é referente as horas extras e seus reflexos. Poderia opinar sobre a legislação do bancário ser de 30 horas semanais e os contratos de trabalho de 40 horas? Por que não existe mudança e acordo nessa questão?

2.7. Quais as perspectivas de mudanças futuras na gestão de pessoas?

2.8. Por que os bancos investem tanto em estratégias da sustentabilidade, em sua opinião? 